University of South Florida

DIGITAL COMMONS

Digital Commons @ University of

@ UNIVERSITY OF SOUTH FLORIDA

South Florida

Research Reports

National Center for Transit Research (NCTR)

Archive (2000-2020)

$6-1-2014$

\title{
Transportation Needs Assessment: Planning Transportation to Meet the Needs of an Aging Illinois
}

CUTR

Follow this and additional works at: https://digitalcommons.usf.edu/cutr_nctr

\section{Recommended Citation}

"Transportation Needs Assessment: Planning Transportation to Meet the Needs of an Aging Illinois," National Center for Transit Research (NCTR) Report No. CUTR-NCTR-RR-2014-01, Center for Urban Transportation Research, University of South Florida, 2014.

DOI: https://doi.org/10.5038/CUTR-NCTR-RR-2014-01

Available at: https://scholarcommons.usf.edu/cutr_nctr/78

This Technical Report is brought to you for free and open access by the National Center for Transit Research (NCTR) Archive (2000-2020) at Digital Commons @ University of South Florida. It has been accepted for inclusion in Research Reports by an authorized administrator of Digital Commons @ University of South Florida. For more information, please contact digitalcommons@usf.edu. 


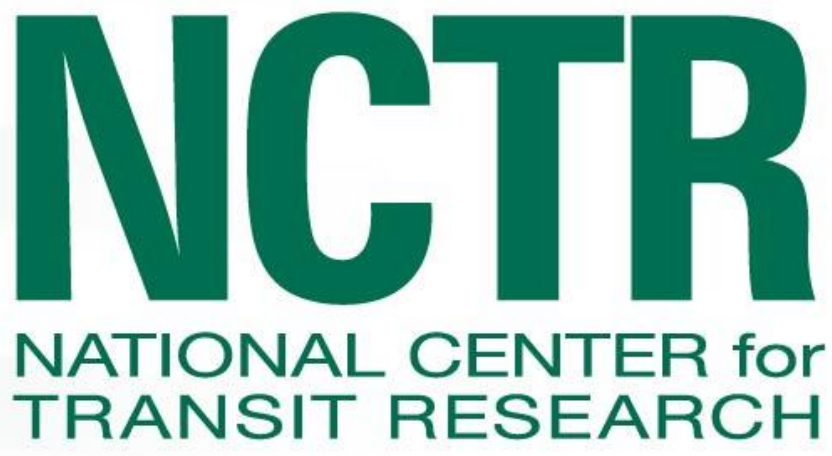

\section{Planning Transportation to Meet the Needs of an Aging Illinois: An Assessment}

Final Report

July 2014

PROJECT NO. 2117-9060-02-C 


\section{Disclaimer}

The contents of this report reflect the views of the authors, who are responsible for the facts and the accuracy of the information presented herein. This document is disseminated under the sponsorship of the Department of Transportation University Transportation Centers Program and the Florida Department of Transportation, in the interest of information exchange. The U.S. Government and the Florida Department of Transportation assume no liability for the contents or use thereof.

The opinions, findings, and conclusions expressed in this publication are those of the authors and not necessarily those of the State of Florida Department of Transportation. 


\title{
PLANNING TRANSPORTATION TO MEET THE NEEDS OF AN AGING ILLINOIS: AN ASSESSMENT
}

\author{
July 2014 \\ Project Team: William (Max) Dieber, \\ Lauren Nolan, Janet Smith, Bradley \\ Winick, Yittayih Zelalem
}
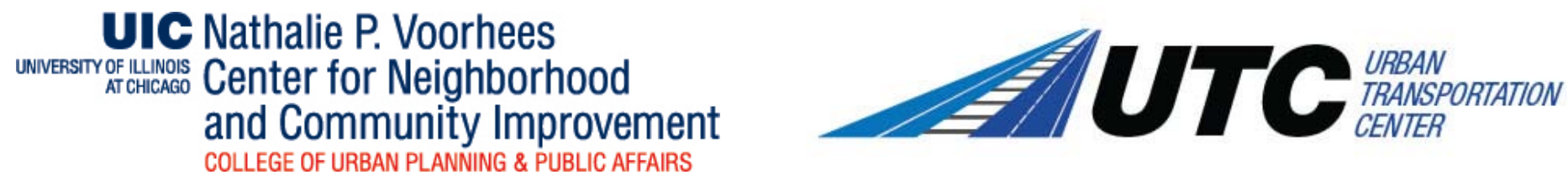

The Nathalie P. Voorhees Center for Neighborhood and Community Improvement (Voorhees Center) is an applied research and technical assistance unit in the College of Urban Planning and Public Affairs (CUPPA) at the University of Illinois at Chicago (UIC). The Voorhees Center is guided by the mission to improve the quality of life for all residents of the City of Chicago, the metropolitan area and nationally. It practices an interdisciplinary approach to community development, addressing quality of life issues that include housing, jobs, good schools, community safety, and transportation. UIC is the largest university in the Chicago area, fully accredited and known nationally and internationally for its research. CUPPA houses the largest graduate school in urban planning, and is a nationally recognized innovator in education, research, and engagement in support of the nation's cities and metropolitan areas. 


\section{Metric Conversion}

\begin{tabular}{|c|c|c|c|c|}
\hline SYMBOL & WHEN YOU KNOW & MULTIPLY BY & TO FIND & SYMBOL \\
\hline \multicolumn{5}{|c|}{ LENGTH } \\
\hline in & inches & 25.4 & millimeters & $\mathrm{mm}$ \\
\hline ft. & feet & 0.305 & meters & $\mathrm{m}$ \\
\hline yd. & yards & 0.914 & meters & $\mathrm{m}$ \\
\hline mi & miles & 1.61 & kilometers & $\mathrm{km}$ \\
\hline \multicolumn{5}{|c|}{ VOLUME } \\
\hline fl. oz. & fluid ounces & 29.57 & milliliters & $\mathrm{mL}$ \\
\hline gal & gallons & 3.785 & liters & $\mathrm{L}$ \\
\hline $\mathbf{f t}^{3}$ & cubic feet & 0.028 & cubic meters & $\mathrm{m}^{3}$ \\
\hline$y d^{3}$ & cubic yards & 0.765 & cubic meters & $m^{3}$ \\
\hline \multicolumn{5}{|c|}{ NOTE: volumes greater than $1000 \mathrm{~L}$ shall be shown in $\mathrm{m}^{3}$} \\
\hline \multicolumn{5}{|c|}{ MASS } \\
\hline oz. & ounces & 28.35 & grams & $g$ \\
\hline lb. & pounds & 0.454 & kilograms & $\mathrm{kg}$ \\
\hline $\mathbf{T}$ & Short tons (2000 lb.) & 0.907 & $\begin{array}{c}\text { megagrams } \\
\text { (or "metric ton") }\end{array}$ & Mg (or "t") \\
\hline \multicolumn{5}{|c|}{ TEMPERATURE (exact degrees) } \\
\hline${ }^{\circ} \mathbf{F}$ & Fahrenheit & $\begin{array}{c}5(F-32) / 9 \\
\text { or }(F-32) / 1.8\end{array}$ & Celsius & ${ }^{\circ} \mathrm{C}$ \\
\hline
\end{tabular}




\section{Technical Report Documentation}

\begin{tabular}{|c|c|c|c|}
\hline $\begin{array}{l}\text { 1. Report No. } \\
2117-9060-02-\mathrm{C}\end{array}$ & \multicolumn{2}{|c|}{ 2. Government Accession No. } & 3. Recipient's Catalog No. \\
\hline \multicolumn{2}{|c|}{$\begin{array}{l}\text { Planning Transportation to Meet the Needs of an Aging Illinois: } \\
\text { An Assessment }\end{array}$} & \multicolumn{2}{|l|}{ July 2014} \\
\hline \multicolumn{4}{|c|}{ 6. Performing Organization Code } \\
\hline \multicolumn{2}{|c|}{$\begin{array}{l}\text { 7. Author(s) } \\
\text { William (Max) Dieber, Lauren Nolan, Janet Smith, } \\
\text { Bradley Winick, Yittayih Zelalem } \\
\text { Urban Transportation Center } \\
\text { University of Illinois at Chicago } \\
412 \text { S. Peoria Street, Suite } 240 \\
\text { Chicago, IL } 60607\end{array}$} & \multicolumn{2}{|c|}{ 8. Performing Organization Report No. } \\
\hline \multicolumn{2}{|c|}{$\begin{array}{l}\text { 9. Performing Organization Name and Address } \\
\text { National Center for Transit Research } \\
\text { Center for Urban Transportation Research (CUTR) } \\
\text { University of South Florida } \\
4202 \text { East Fowler Avenue, CUT100 } \\
\text { Tampa, FL 33620-5375 }\end{array}$} & \multicolumn{2}{|c|}{ 10. Work Unit No. (TRAIS) } \\
\hline \multicolumn{4}{|c|}{ 11. Contract or Grant No. } \\
\hline \multicolumn{2}{|c|}{$\begin{array}{l}\text { 12. Sponsoring Agency Name and Address } \\
\text { Research and Innovative Technology Administration } \\
\text { U.S. Department of Transportation } \\
\text { Mail Code RDT-30, } 1200 \text { New Jersey Ave SE, Room E33 } \\
\text { Washington, DC 20590-0001 }\end{array}$} & \multicolumn{2}{|c|}{ 13. Type of Report and Period Covered } \\
\hline \multicolumn{4}{|c|}{ 14. Sponsoring Agency Code } \\
\hline \multicolumn{4}{|l|}{ 15. Supplementary Notes } \\
\hline \multicolumn{4}{|l|}{ 16. Abstract } \\
\hline \multicolumn{4}{|c|}{$\begin{array}{l}\text { Illinois has for over a decade specifically addressed the transportation needs of older adults as part of its } \\
\text { required Human Services Transportation Plans (HSTP). The state's HST planning efforts in the } 11 \text { HSTP regions } \\
\text { are intended to integrate with the ongoing work of the aging networks working in coordination with the state's } \\
13 \text { regional Area Agencies on Aging (AAAs). This report represents a snapshot of the impact of the intended } \\
\text { coordinated HST planning throughout Illinois to date, and discusses promising practices, enduring issues and } \\
\text { challenges, and provides recommendations for potential enhancements. }\end{array}$} \\
\hline \multicolumn{2}{|l|}{ 17. Key Words } & \multicolumn{2}{|c|}{$\begin{array}{l}\text { 18. Distribution Statement } \\
\text { No restrictions }\end{array}$} \\
\hline $\begin{array}{l}\text { 19. Security Classification } \\
\text { (of this report) } \\
\text { Unclassified }\end{array}$ & $\begin{array}{l}\text { 20. Security Classification } \\
\text { (of this page) } \\
\text { Unclassified }\end{array}$ & $\begin{array}{l}\text { 21. No. of Pages } \\
108\end{array}$ & 22. Price \\
\hline
\end{tabular}


Funding for this report comes from the Metropolitan Transportation Support Initiative (METSI).

\section{About the Metropolitan Transportation Support Initiative (METSI):}

The Metropolitan Transportation Support Initiative (METSI) at the Urban Transportation Center (UTC) at the University of Illinois at Chicago (UIC) brings together faculty, students, and transportation researchers to address topical issues with the goal to provide thoughtful planning and problem-solving solutions. These include: Transportation efficiency, safety, traffic congestion, air quality, economic development and smart growth.

METSI was created in September 1999 with a grant from Illinois Department of Transportation (IDOT). This Technical Work Program outlines the process to address current and emerging issues of urban transportation and to continue projects already in process.

The purpose of METSI is threefold:

1. To continue to conduct topical transportation research.

2. Undertake technical assistance.

3. And provide education and training to the state of Illinois, IDOT and other transportation and planning agencies in the State of Illinois.

The current theme for METSI research is Livability and Sustainable Transportation. 


\section{TABLE OF CONTENTS}

\section{INTRODUCTION}

Report Terminology

SECTION 1: POPULATION PROJECTIONS

Summary of Results

Summary of Methodology

SECTION 2: DEMOGRAPHIC CHARACTERISTICS OF THE OLDER ADULT POPULATION

Demographic Characteristics

Housing Characteristics

Transportation \& Mobility Characteristics

SECTION 3: CURRENT HUMAN SERVICES TRANSPORTATION PLANNING PRACTICE

IN ILLINOIS

History \& Description $\quad 31$

Current Status $\quad 31$

Stakeholder Conversations $\quad 33$

Key Findings from Stakeholder Conversations 33

Key Current Illinois HSTP Practice Findings 36

Notable HSTP Practices in Illinois $\quad 37$

Notable HSTP Practices Around the Country $\quad 39$

SECTION 4: CONCLUSIONS \& RECOMMENDATIONS 45

Facilitating Aging-In-Community $\quad 45$

Enhancing HSTP Coordination in Illinois $\quad 45$

Enhancing HSTP Coordination at the Federal Level $\quad 46$

$\begin{array}{lr}\text { APPENDICES } & 49\end{array}$ 


\section{LIST OF FIGURES}

Figure 1: Population by Selected Age in Illinois, 2000 to 2030

Figure 2: Change in Population 65 and Older in Illinois 2010 to 2030

Figure 3: Change in HSTP Region and AAA Area Population 65 and Older in Illinois, 2010 to 20306

Figure 4: Illinois Population as a Percent of US Total $\quad 8$

Figure 5: Population Change in Illinois, 2000 to 2010

Figure 6: Population 65 and Older as Percent of Total Population, 1990 to 203010

Figure 7A: Proportion of Residents Age 65+ by County 13

Figure 7B: Population of Residents Age 75+ by County 14

Figure 7C: Population of Residents Age 85+ by County 14

Figure 8: Proportion of Residents Age 65+ Living Alone $\quad 15$

Figure 9: Percent of Persons with a Disability by County 16

Figure 10A: Proportion of Single Unit Homes $\quad 19$

Figure 10B: Proportion of Multi-Unit Homes (Two or More Units) 19

Figure 10C: Proportion of Mobile Homes $r$

Figure 11: Proportion of Cost-Burdened Homeowners Age 65+ 22

Figure 12: Proportion of Cost-Burdened Renters Age 65+ 24

Figure 13: Proportion of Commutes via Public Transit 26

Figure 14: Proportion of Commutes via Carpool 27

Figure 15A: Proportion of Households without a Vehicle, All Ages 29

Figure 15B: Proportion of Households without a Vehicle, Age 65+ 29

Figure 16: Public Transit Availability by County 30

\section{LIST OF TABLES}

Table 1: Selected Population Characteristics $\quad 7$

Table 2: State of Illinois Older Adult Population Distribution 12

Table 3: Counties with the Highest Proportion of Older Adult Residents 13

Table 4: Counties with the Highest Proportions of those 65+ Living Alone 15

Table 5: Counties with the Highest Proportions of Residents with a Reported Disability 16

Table 6: Housing Typologies 17

Table 7A: Proportion of Single Unit Attached/Detached Homes $\quad 18$

Table 7B: Proportion of Multi-Unit Homes $r$

Table 7C: Proportion of Mobile Homes $r$

Table 8: Older Adults \& Housing Tenure $\quad 21$

Table 9: Older Adults \& Mortgage Status $\quad 21$

Table 10: Cost-Burdened Homeowners by Age $\quad 22$

Table 11: Counties with the Highest Proportion of Cost-Burdened Older Adult Homeowners 22

Table 12: Rent-Burdened Households 23

Table 13: Counties with the Highest Proportion of Burdened Renters Age 65+ 23

Table 14: Mode of Travel to Work by Age $\quad 25$

Table 15: Transit Usage $\quad 25$

Table 16: Proportion of Commutes via Carpool $\quad 27$

Table 17: Percent of All Households without a Vehicle $\quad 28$

Table 18: Percent of Householders Age 65+ without a Vehicle 28 


\section{INTRODUCTION}

Illinois' older adult population is growing rapidly. Statewide, the 65+ population currently includes just more than one of eight Illinoisans, but by 2030 it will include one of every five Illinoisans. The sub-group of older adults 85 and older is the fastest growing segment of the older adult population, and this group's increasing housing, transportation and human and health care service needs will require even more detailed attention as Illinois plans for its future population.

While older adults in Illinois are living longer than in past decades, there are two distinct health-related trends at play. Many older adults are living longer and healthier lives, due in part to improved medical care, lifestyle choices made throughout their lives, and an increased focus on preventive health care and wellness. However, the numbers of older adults suffering from chronic diseases (both physical ones such as diabetes and obesity, as well as cognitive ones such as Alzheimer's Disease and dementia) are also growing substantially.

For a combination of reasons, including the recent shift towards home and community-based health care services, Illinois' future appears likely to include the need to recognize and support its older adult population successfully and healthily aging within their homes and communities. To successfully meet this future, Illinois and its regions and communities needs to address its transportation, housing, and human service challenges in an integrated manner.

States, regions and communities nationwide are grappling with variations on these challenges. In the realm of transportation, every geography is working on better coordinating its different service providers, as service is often inconsistent, limited by political or funding jurisdictions, financially challenging, poorly linked with health care and human service providers, and spatially inadequate for many potential users. In addition, potential users often have limited knowledge about, understanding of, or mastery with different potential transportation services.

Illinois has for over a decade specifically addressed the transportation needs of older adults as part of its required Human Services Transportation Plans (HSTP). The state's HST planning efforts in the 11 HSTP regions are intended to integrate with the ongoing work of the aging networks working in coordination with the state's 13 regional Area Agencies on Aging (AAAs).

This report represents a snapshot of the impact of the intended coordinated HST planning throughout Illinois to date, and discusses promising practices, enduring issues and challenges, and provides recommendations for potential enhancements.

This report is comprised of three sections. Section 1: Population Projections reviews the current and projected statewide populations, and provides projections for Illinois' HSTP Regions and AAA planning areas as a backdrop for future HST planning; Section 2: Demographic Characteristics of the Older Adult Population evaluates housing, transportation and mobility characteristics throughout Illinois to identify what older adults' needs are and where they will be most required; Section 3: Current Human Services Transportation Planning Practice in Illinois reviews focused conversations held with key HSTP and AAA stakeholders statewide, and offers a series of conclusions and recommendations for improvement. 


\section{REPORT TERMINOLOGY}

A variety of terms are used somewhat interchangeably in the literature on aging and communities. Terms used to describe the issue of developing and maintaining aging-supportive communities is called variously "aging-incommunity", "aging-in-place", "successful aging", "healthy aging", "sustainable communities" and others. Terms describing communities that are said to be supportive of the ability of residents to age within a community rather than have to move at some point to a community more supportive of residents' evolving needs include "age-friendly communities", "lifelong communities", "livable communities", "lifespan communities", "ageless communities", "multigenerational communities" and others. Even how to refer to older individuals themselves is disputed amongst different stakeholders, with terms such as "senior citizens", "elderly", "older adults", "elders," "Baby Boomers," and others used somewhat interchangeably.

For purposes of consistency and clarity, this report will primarily use the terms "older adults", "aging-incommunity" and "aging-supportive communities". We will use "older adults" in part out of deference to those individuals who feel marginalized by some of the alternative terms. We will use "aging-supportive communities" in part because many of the alternative terms refer to specific community-focused programs or protocols, and our intent is to address the broader issue rather than focus or any particular programs. In general, as this report takes a community-based perspective, we will use the term "aging-in-community" rather than "aging-in-place" which to many connotes an emphasis on remaining in one's current dwelling and is therefore often overly dwelling-centric rather than community-centric. The only exceptions to these nomenclature preferences are when specifically referencing existing programs or institutions. 


\section{SECTION 1: POPULATION PROJECTIONS}

The "Baby Boom" population refers to those born between 1946 and 1964 . As of 2010 this group ranged in age from 46 to 64. This lump in the population distribution is a dominating factor on the American landscape in many ways. Moving forward to 2030 this dominance will present challenges to the private and public sector's ability to provide older adult services. According to the most recent mid-range projections of the US Bureau of the Census (released December 12, 2012), the nation's total population will increase by $16.1 \%$ between 2010 and 2030. Over the same span the population age 65 and older will grow by $80.7 \%$. This population group's share of the total will increase from $13.0 \%$ to $20.3 \%$. While the shares and rates of growth are different, the same relative change is expected for Illinois. In exploring projected future changes in the population in Illinois, several alternatives were created. One of these, a reasonably conservative option identified herein as Alternative G, shows the total statewide growth will be $11.7 \%$ and the increase in the population age 65 and older will be $75.8 \%$. The older adult population's share will increase from $12.5 \%$ in 2010 to $19.7 \%$ in 2030 . The growth in the older adult population from 2010 to 2030 accounts for $81.5 \%$ of the total Illinois increase of 1,496,685.

The older adult population is divided into three subgroups: 65-74 years of age (often referred to as the "young old"), 75-84 years of age (the "middle old"), and 85 years of age and older (the "old old"). In 2010 the baby boom group had not yet reached the youngest of these three groups. By 2030, this group will be entirely in the older adult years but will not yet have reached 85. During the projection period, therefore, we should expect to see first relative growth in the number of "young old" followed by large increases in the number of "middle old." Very substantial growth in the "old old" group will not occur until after 2030. The relative sizes of these population are illustrated in the following chart.

The growth in the number of older adults in Illinois and the United States up to 2030 should not be viewed as a onetime "pig in a python" phenomenon. For the US as a whole, as presented in the Census Bureau projections to 2060, a combination of increased lifespans, large post baby-boom generations, and immigration patterns will combine to produce continuing increases in the older adult population and a flattening of the peaks and valleys in the overall age distribution. Observed net out-migrations in the younger adult populations in Illinois and, especially, in many of its counties may dampen this growth somewhat.

Between 2010 and 2030 the State of Illinois will see a gain of $76.3 \%$ or 648,129 in the $65-74$ population, a gain of $79.8 \%$ or 418,798 in the $75-84$ population, and a gain of $65.1 \%$ or 152,866 in the $85+$ population.

To explore the notion of cohort changes, the 55 to 64 age group is also shown in Figure 1. This group grows by only $4.3 \%$ in the projection period but this modest increase is the result of a 263,101 growth in 2010 to 2020 and a loss of 200,234 in the 2020 to 2030 span. Observe that the 55-64 cohort in 2010 (the light grey bar in the leftmost cluster) becomes the 65-74 year old group in 2020 (the dark grey bar in the second cluster) and the 75-84 year old group in 2030 (the black bar in the third cluster). By comparing the relative heights of these bars (light grey then dark grey then purple) the combined effect of the initial age distribution, ten year survival assumptions, and net migration on a cohort can be observed. 
Figure 1: Population by Selected Age in Illinois, 2000 to 2030 (Alt G)

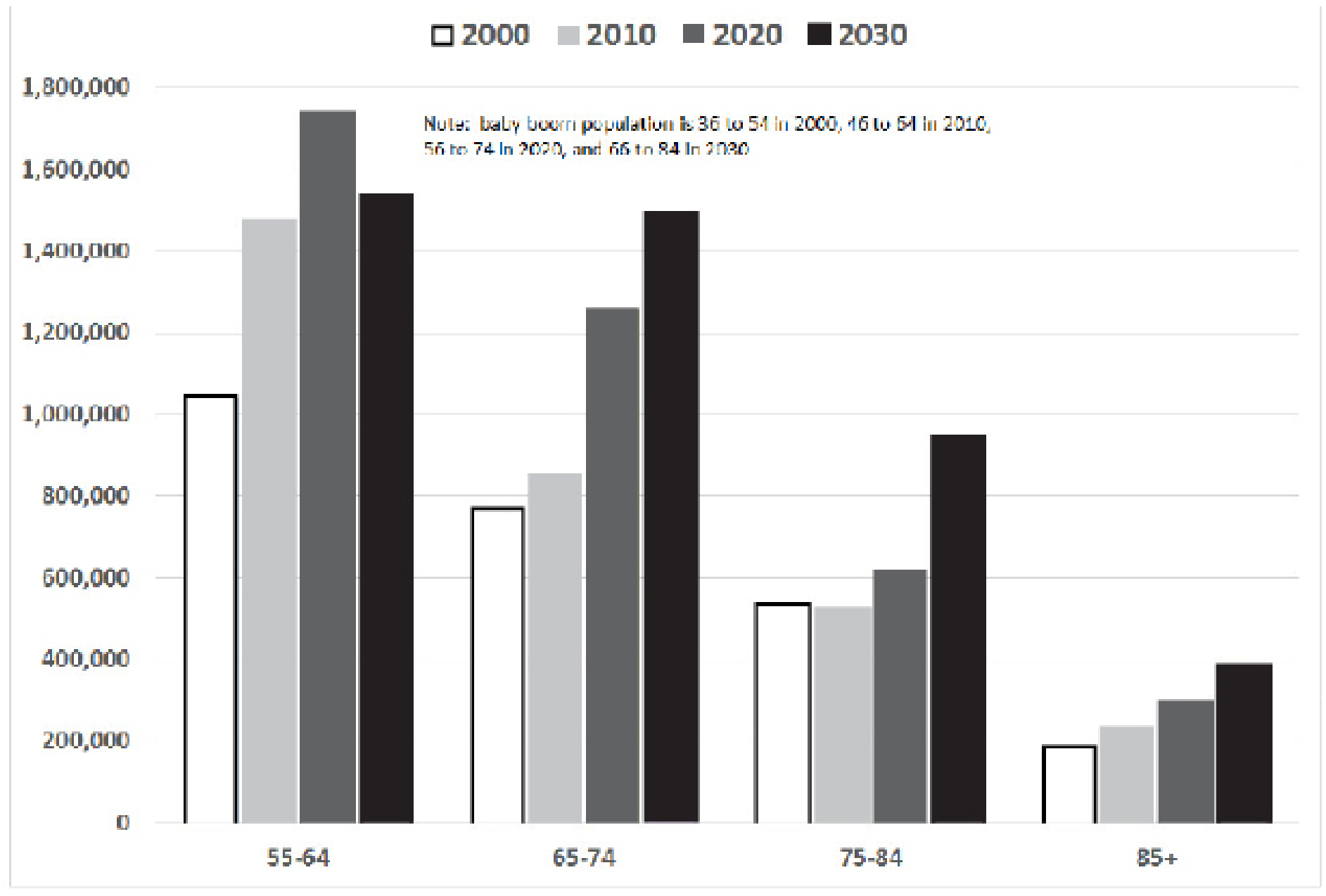


Figures 2 and 3 demonstrate rates of growth and older adult population shares for counties, HSTP regions, and Area Agency on Aging areas.

Figure 2: Change in Population 65 and Older in Illinois Counties 2010 to 2030 (Alt G)

\section{Percent Change}

\begin{tabular}{|l}
\hline \\
$\square$ \\
\hline \\
40 to $60 \%$ \\
60 to $65 \%$ \\
85 to $120 \%$ \\
Over $120 \%$ \\
\hline
\end{tabular}

Statewide Change is 75.8

Labels indicate 65 and older's share of total population in 2010 (top) and 2030 (bottom)

Statewide shares are $12.5 \%$ and $19.7 \%$. Nationwide shares are $13 \%$ and $20.3 \%$

Source: 2010 Census and Alternative $\mathrm{G}$ Population Projection

Urban Data Visualization Lab June 2014

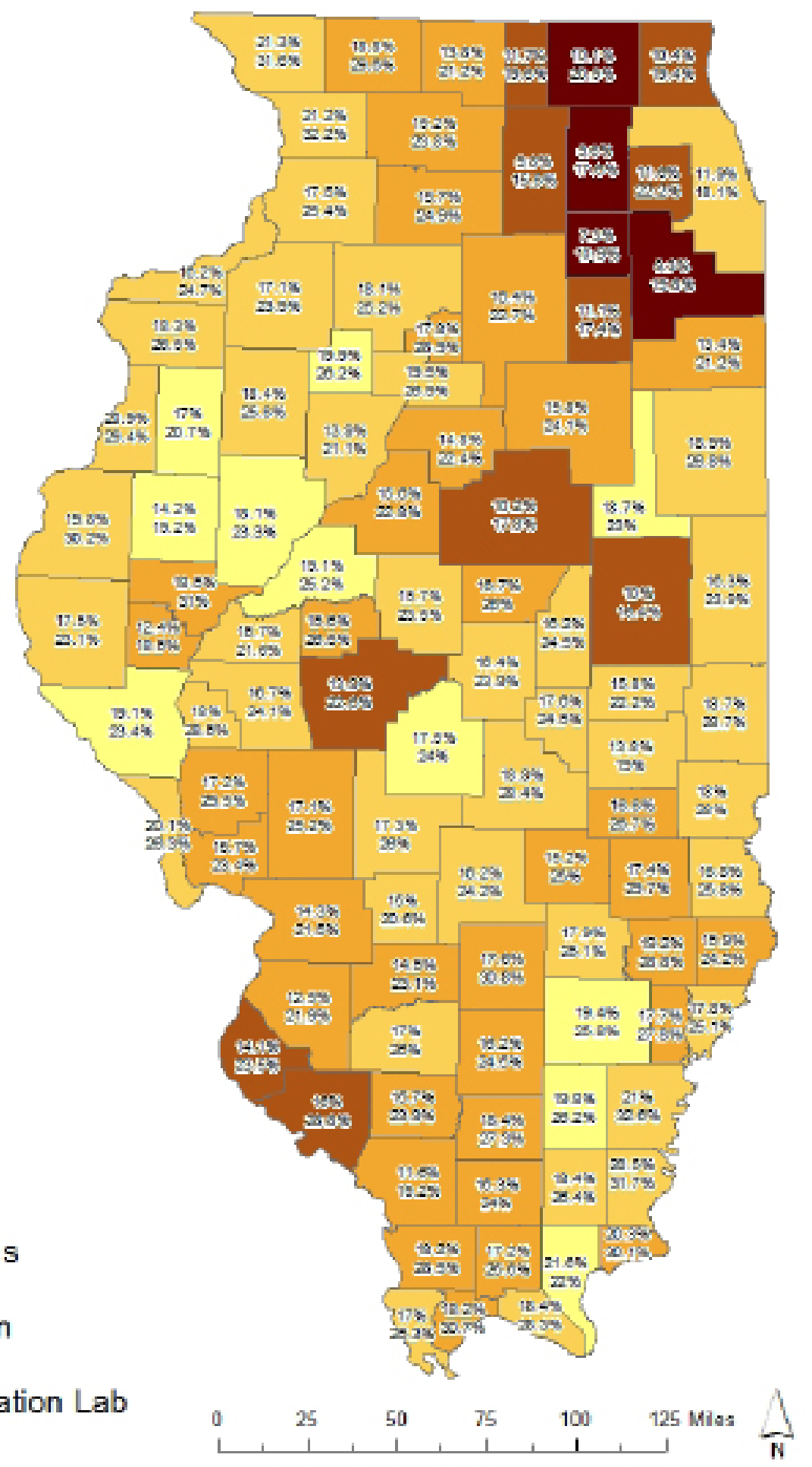


Figure 3: Change in HSTP Region and AAA Area Population 65 and Older in Illinois, 2010 to 2030 (Alt G)
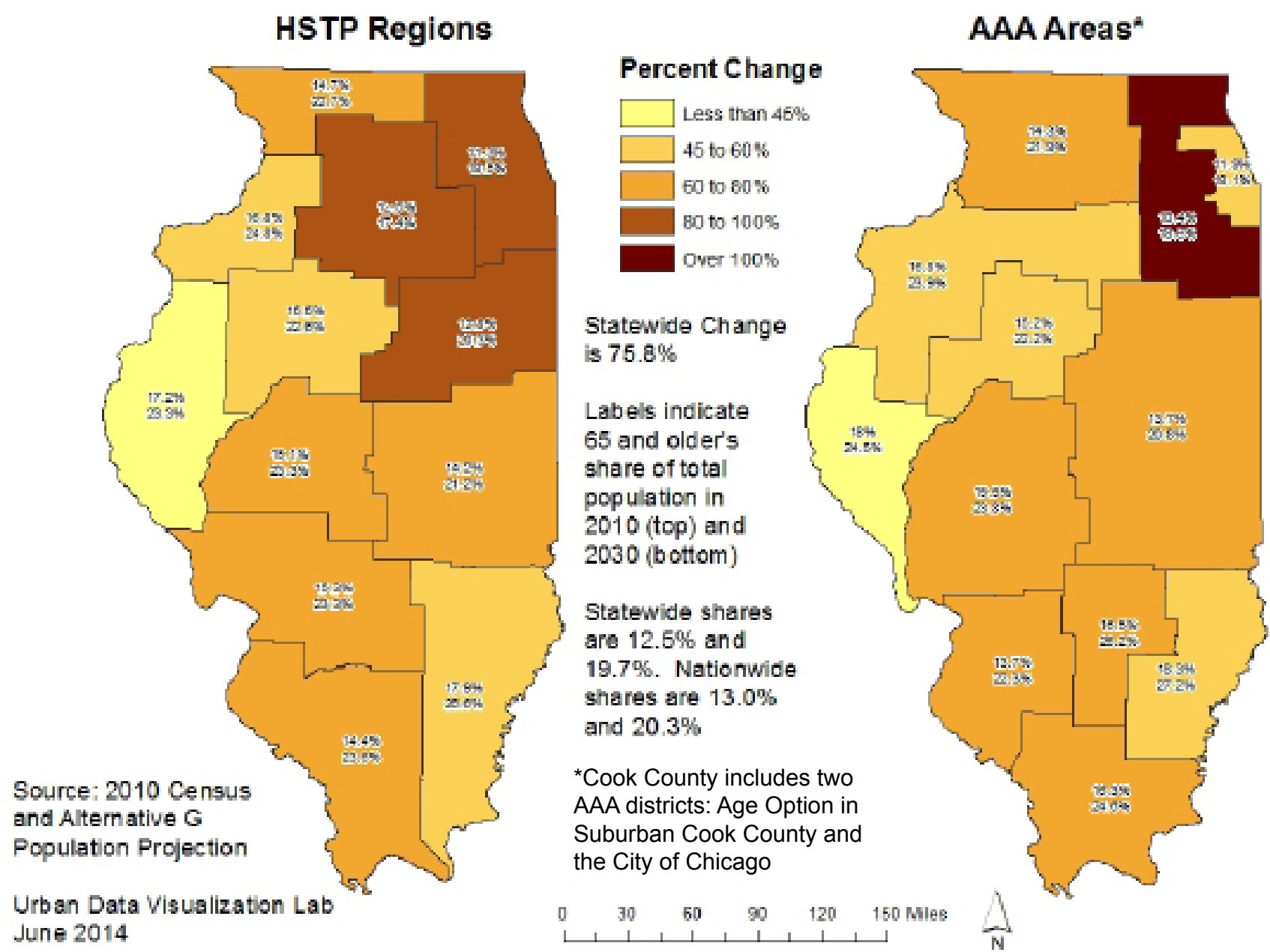

Appendix A summarizes the change in the older adult populations for the fastest and slowest growing counties in Illinois. Appendix B and Appendix C provide the projected change in total and older adult population for HSTP regions and AAA areas.

Projections were also developed for population living in nursing homes, in other group quarters, in one person households, in other households, and for population in the labor force. These projections for the state as a whole are shown in Table 1 for the 65-74 year old age group and for population 75 and older. These rates of growth are comparable to the overall growth in the older adult population. 
Table 1: Selected Population Characteristics

\begin{tabular}{|c|c|c|c|c|c|c|}
\hline & Age & $\begin{array}{r}\text { Population in } \\
\text { Nursing Homes }\end{array}$ & $\begin{array}{r}\text { Population in Other } \\
\text { Group Quarters }\end{array}$ & $\begin{array}{r}\text { Population in One } \\
\text { Person Households }\end{array}$ & $\begin{array}{r}\text { Population in } \\
\text { Other Households }\end{array}$ & $\begin{array}{r}\text { Population in } \\
\text { Labor Force }\end{array}$ \\
\hline \multirow[t]{2}{*}{2010} & $65-74$ & 10,072 & 2,883 & 190,828 & 645,752 & 221,339 \\
\hline & $75+$ & 50,845 & 4,415 & 278,028 & 426,390 & 44,615 \\
\hline \multirow[t]{2}{*}{2030 (G) } & $65-74$ & 17,264 & 4,970 & 331,625 & $1,143,805$ & 393,853 \\
\hline & $75+$ & 86,375 & 7,533 & 483,703 & 753,729 & 78,934 \\
\hline \multirow[t]{2}{*}{ Change } & $65-74$ & 7,192 & 2,087 & 140,797 & 498,053 & 172,514 \\
\hline & $75+$ & 35,530 & 3,118 & 205,675 & 327,339 & 34,319 \\
\hline \multirow[t]{2}{*}{ Percent Change } & $65-74$ & $71.4 \%$ & $72.4 \%$ & $73.8 \%$ & $77.1 \%$ & $77.9 \%$ \\
\hline & $75+$ & $69.9 \%$ & $70.6 \%$ & $74.0 \%$ & $76.8 \%$ & $76.9 \%$ \\
\hline
\end{tabular}

All 2010 data with the exception of the Population in Labor Force are derived from the 2010 Decennial Census. The Labor Force estimate is based upon participation rates estimated from the Census Bureau's 2010 One Year American Community Survey

\section{SUMMARY OF METHODOLOGY}

\section{Development of State and County Total Population Projections.}

The initial step in the process was the evaluation of the official projections for the State of Illinois and its counties produced by the Department of Commerce and Economic Opportunity (DCEO) in 2005. These results projected population by age and sex, Hispanic origin, and selected race groups out to the year 2030. In the analysis conducted here, only results for total population by age for counties were evaluated. Central to the evaluation was the comparison of DCEO projections for 2010 against Decennial Census 2010 results. In general, the DCEO projections were significantly higher than the census enumerated populations. The projected 2010 total of 13,279,091 was 448,459 higher than the enumerated total of 12,830,632. The projected 2000 to 2010 rate of growth was shown as $6.7 \%$ compared to the actual change of $3.1 \%$. The projected amount of growth overstated the actual growth by $115 \%$. It is clear that without adjustment or complete revision, the DCEO results are not useful. A complete revision, to be done properly, would require the development of needed natural increase and migration baseline data for 102 Illinois counties. Unfortunately, some of the needed vital statistics data are not yet available so calibration of migration assumptions is not possible at this point. Additionally, the time and resources needed to prepare such a revision are beyond the scope of this project.

Instead, results for each county were developed by either using DCEO's projected rates of total population change for 2010 to 2020 and for 2020 to 2030 but applied to the correct 2010 base population or by adjusting these rates of change by factors related to the observed differences in the rates of change from 2000 to 2010 . The basic operating assumption here is that DCEO's birth rate, life expectancy, and net migration assumptions for one county relative to the next were generally acceptable requiring adjustments reflecting observed but unmeasured differences in the 2000 to 2010 span.

Adams County provides an example of how this approach is applied. In this county, DCEO's projected 2000 to 2010 growth was $2.66 \%$ compared to the actual rate of $-1.88 \%$, a difference of -4.54 percentage points. DCEO's projected rates for the 2010 decade and the 2020 decade were $8.63 \%$ and $2.78 \%$, respectively. Rates based on the observed differences were applied in different ways to produce the alternative. In one alternative (Alternative E), these DCEO rates were applied but starting with the accurate 2010 base. In another alternative (Alternative F) these rates were adjusted down by 4.54 percentage points, becoming $4.09 \%$ for the 2010 decade and $-1.76 \%$ for the 2020 decade. In Alternative G, the 4.54 adjustment was revised to 2.27 (half) for the 2010 decade and 1.14 (half again) for the 2020 decade. This produced a 6.36 rate for the 2010 to 2020 span and $1.64 \%$ for the 2020 to 2030 span. 
A similar procedure was applied to each county then results were totaled to produce alternative statewide totals. Figure 4 displays these statewide results in comparison with the DCEO projections. Alternatives F and G appear to be the best alternatives.

Figure 4: Illinois Population as Percent of US Total (2012 Census Projection)

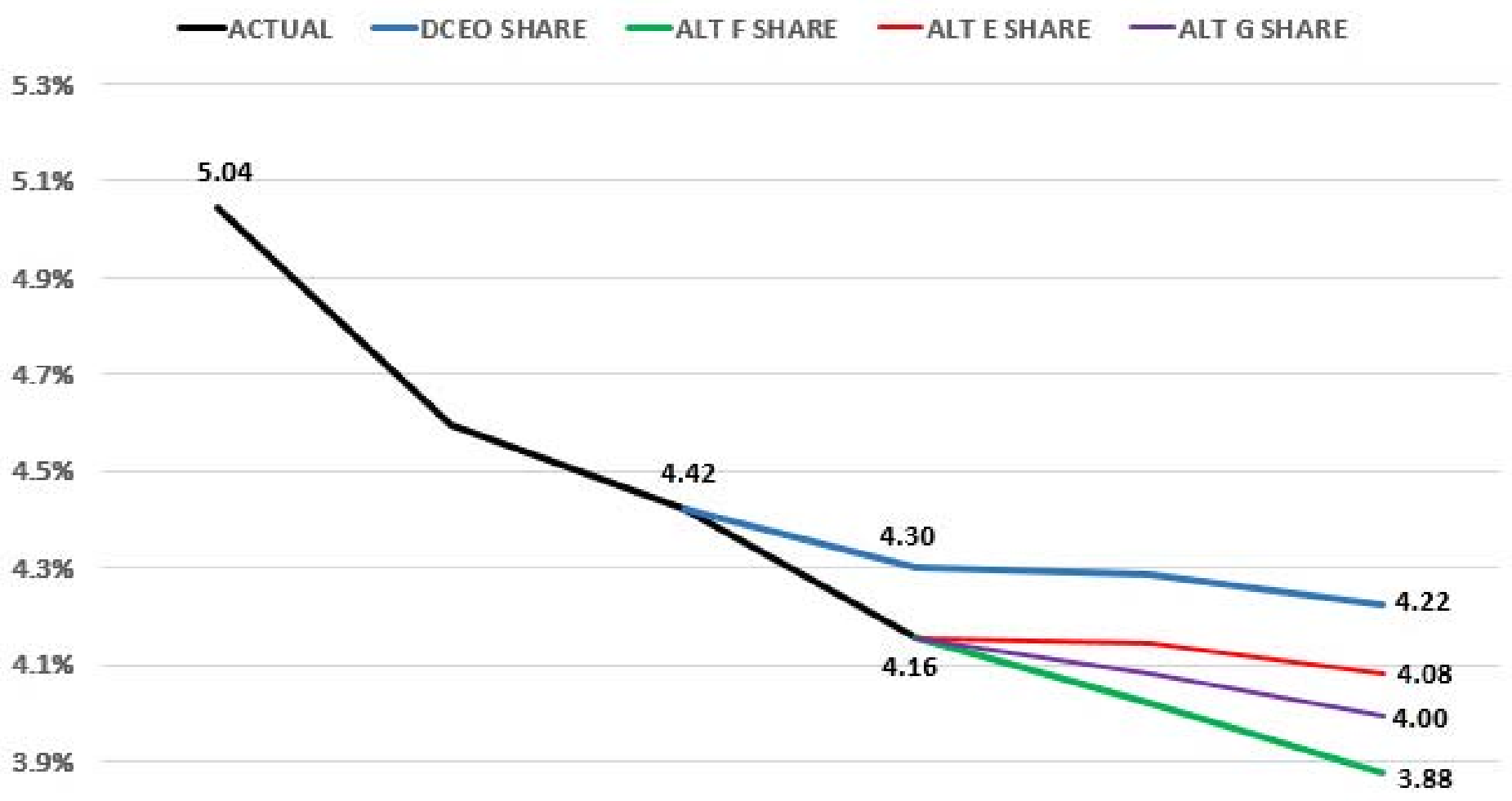

$3.7 \%$

$3.5 \%$

1980

19902000

2010

2020

2030

Another approach to evaluating the reasonableness of these results is to compare these totals against the current projections for the United States. These projections were provided by the Census Bureau in December 2012 and project out to the year 2060. Given the observed change in Illinois' share of the total U.S. population between 1980 and 2010 as observed in Figure 4, Alternatives F and G appear to be the most reasonable.

Because Alternative F adjusted DCEO projected 2010 to 2030 per decade growth rates by the full size of the difference between actual and DCEO 2000 to 2010 rates of change, the results for counties with very large 2000 to 2010 differences in the growth rates were questionable. The Alternative G results, based on the modified rate differences, generated much more reasonable results at the county level, and was therefore used by the project team as the basis for its detailed projections.

Development of Projections of the Older Adult Population for Illinois and Counties. With the objective of producing alternative 2020 and 2030 projections for population aged 65-74, 75-84, and 85 and older, population totals in these three groups plus population 35-44, 45-54, and 55-64 were evaluated. As with the statewide analysis for total population, the initial step was to compare actual change with the DCEO projected change in the 2000 to 2010 span. Statewide, each age group appears to have contributed to the DCEO over- 
projection. Note, however that the population under 45 years of age represented $60.4 \%$ of the State's actual 2010 population, yet accounted for $77.9 \%$ of the difference between DCEO's 2010 total statewide population and that as reported in the 2010 Decennial Census. Population in the 55 to 74 years of age group - the group of primary interest in developing the projections - accounted for $22.2 \%$ of the 2010 population, but only $4.8 \%$ of the error. Interestingly, the 85 and older population group contributed substantially more to the over-projection than would be expected based on their share of the total 2010 population. This is unlikely to be the result of underestimation in life expectancy since mortality rates do not change that rapidly under normal circumstances. Instead it is probably the result of an underestimate of in-migration and/or an overestimate of out-migration.

Figure 5: Population Change in Illinois, 2000 - 2010

\section{Actual DCEO Projected}

500,000

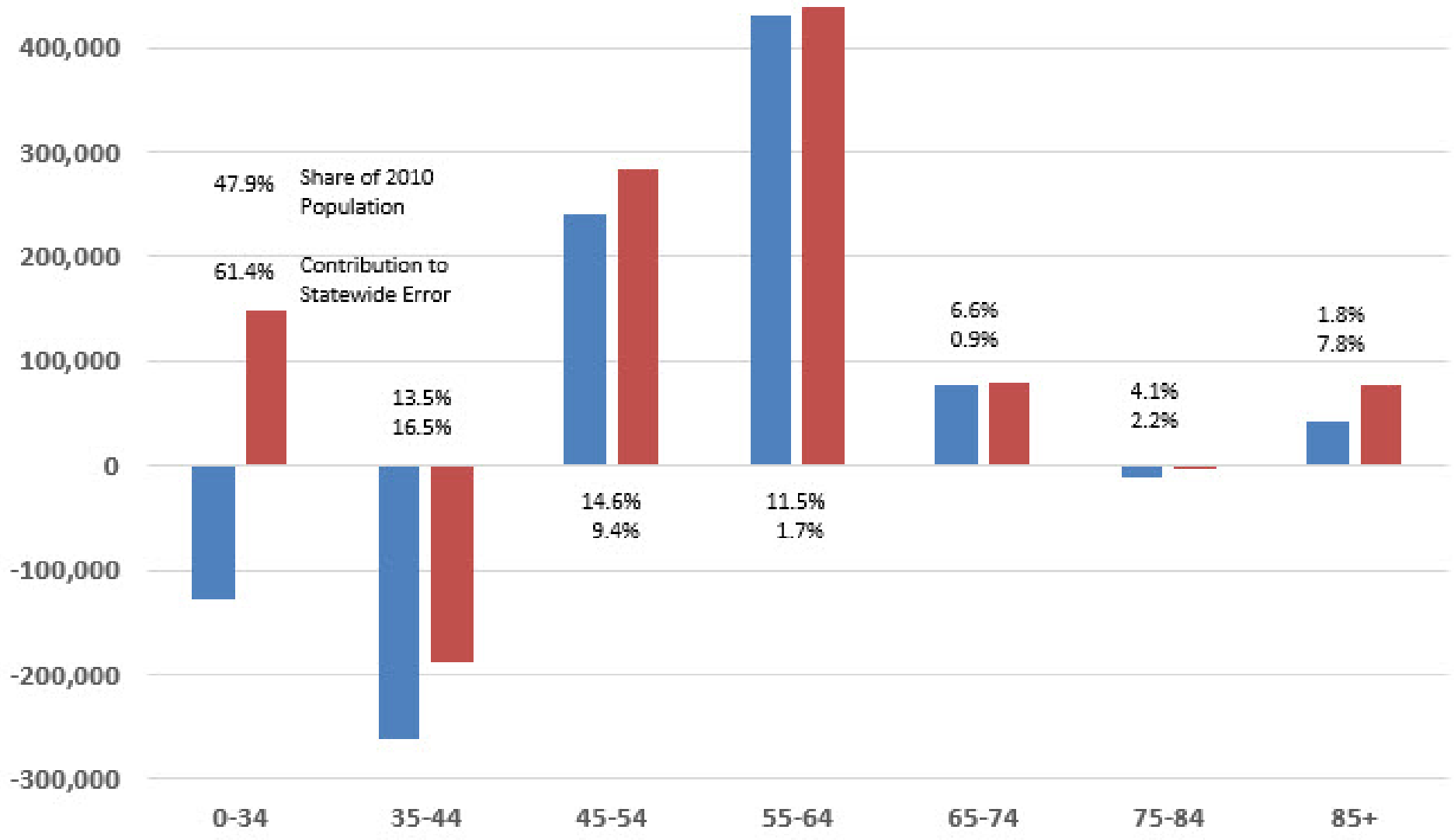

The county alternatives were produced by first identifying the error at the county level for the cohorts noted above with the exception of the 0-34 year old group. As with the statewide total population projections, this error became the basis for adjustments to the DCEO projected rates of change for each of the target cohorts. Again, Adams County provides an example.

In 2000, the 45-54 population group in the County was 8,911. In 2010 this same cohort, now 55-64, had decreased to 8,419 - a drop of 5.52\%. The DCEO projections reduced this group to 8,317 - a drop of $6.67 \%$. The percentage point difference of +1.14 became the basis for adjusting DCEO's 2010 to 2020 and 2020 to 2030 projected change for each 45-54 to 55-64 change for Alternative F. For Alternative G, this adjustment factor was halved for 2010-2020 and halved again for 2020 to 2030. In Alternative E, the DCEO projected rates of change for the cohort were applied but starting with the actual 2010 population. Appendix D presents the full 
calculations for Adams County. These calculations were applied to each of the target age groups in each county for the three alternatives. The State totals for the target age groups were the sum of the county results for each alternative.

Figure 6 summarizes the percent of the total population aged 65 and older for the Alternatives as well as for the US as a whole. The differences between Alternatives E, F, and G do not appear to be substantial.

Figure 6: Population 65 and Older as Percent of Total Population, 1990 to 2030

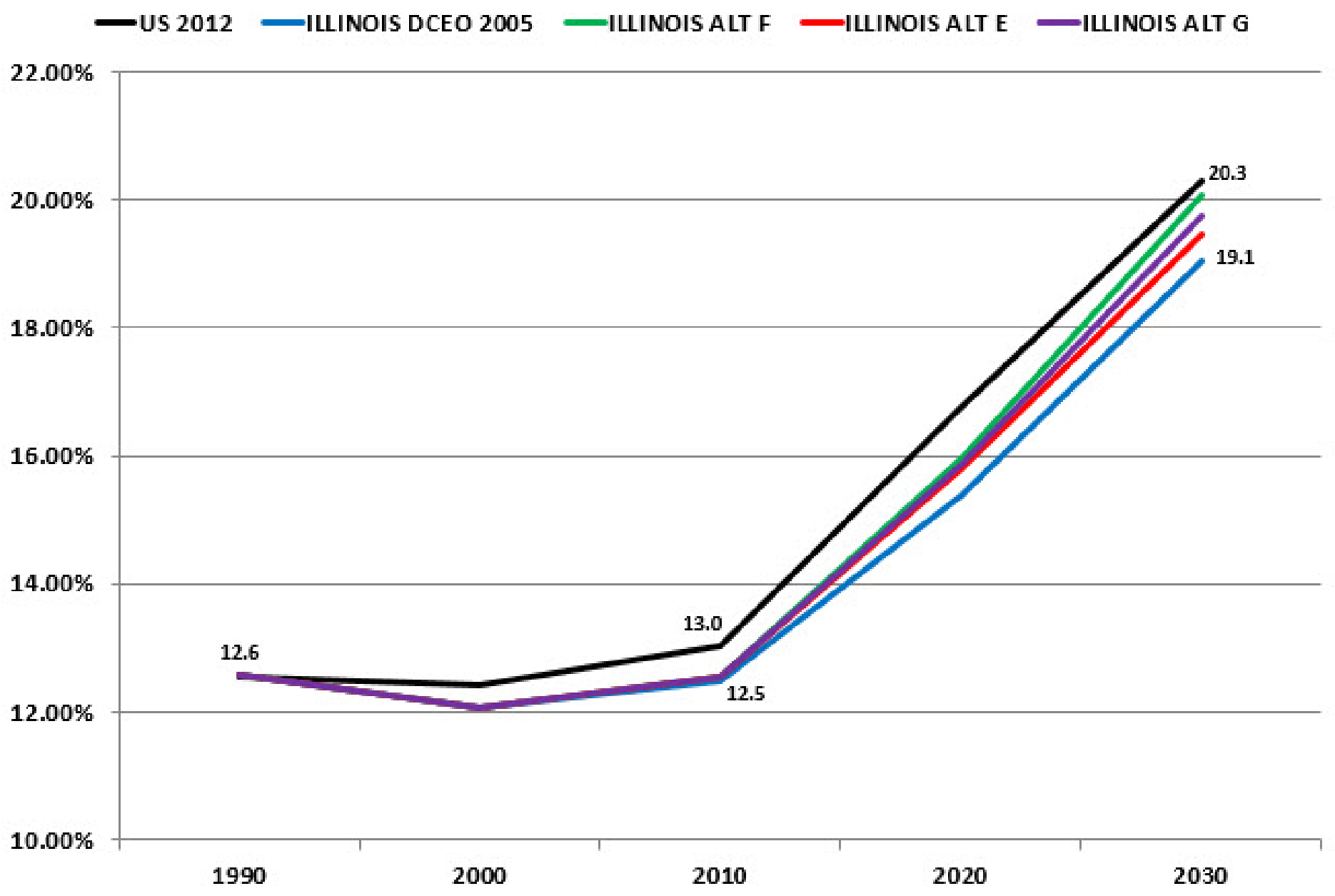

Development of Projections for HSTP Regions and AAA Areas. Totals for HSTP and AAA regions and areas were produced by aggregating county results. The county to HSTP region definitions were provided by the Urban Transportation Center at UIC. The county to AAA areas were based on definitions downloaded from the Illinois Department of Aging on March 25, 2014.

Development of Nursing Home, Group Quarters, One Person Households, Population in Multiple Person Households and Labor Force. 2010 Summary File 1 data for population in nursing homes by county and age was derived from Table PC05. 2010 Summary File 1 data for population in group quarters by county and age was derived from Table PC01. 2010 Summary File 1 data for population living alone by county and age was derived from Tables P25 and P26. Labor Force rates for population aged 65-74 and 75 and over were downloaded from the 5 year 2008-2012 American Community Survey by county. These rates were then applied to the 2010 
Decennial data to estimate 2010 labor force at the county level. Older adult population residing in multiple person households was calculated by subtracting older adult population in group quarters and in single person households from the total older adult population. The projected values for all these characteristics of the older adult population were built by applying the 2010 actual or estimated rates to the changes in the age distribution by county. Results for the State, for HSTP regions, and AAA areas were then produced by aggregating county results. These statewide results, based on Alternative G, are summarized in Appendix E and F.

\section{Understanding Population Projections}

The Alternative $G$ projections show the greatest rates of older adult population growth from 2010 to 2030 are on the edges of the Chicago metropolitan area. An area containing Boone, DeKalb, Lake, McHenry, Kane, Kendall, and Will counties is projected to see a 132\% growth in population 65 and older. This compares with a growth rate of $32 \%$ for the total population in the same counties. Cook and DuPage counties also gain a substantial number of older adults with a projected growth rate of $66 \%$. Other counties showing substantial growth in the older adult population are those in the St. Louis metropolitan area and the counties containing Springfield, Bloomington-Normal, and Urbana-Champaign.

Counties with the slowest projected rates of growth in the older adult population are found in the western and southern regions of the state. In many of these counties, the older adult population is already a high proportion of the total population. These proportions will become even greater as it appears that the younger population is moving away. 


\section{SECTION 2: DEMOGRAPHIC CHARACTERISTICS OF THE OLDER ADULT POPULATION}

As Section 1 indicates, the Baby Boom generation marked an unprecedented upsurge in the US population. As this generation enters their older adult years, Illinois must plan for major shifts in required services, housing preferences, and mobility needs associated with older adults. In this section, we paint a demographic picture of the older Illinois population in order to understand what these needs are and where they will most be required. The demographic indicators we examine in this section fall under three categories: (1) Demographic Characteristics, (2) Housing Characteristics, and (3) Transportation and Mobility Characteristics. These three categories were identified as crucial to the needs of residents as they age. Through a detailed examination of conditions across the state, we seek to identify potential areas of need as well as areas that are conducive to agingin-community.

The majority of the data used in this section are from the 2008-2012 Five-Year American Community Survey. The section that preceded used 2010 Census data for its population projections. Therefore, certain figures such as total population or age counts will differ, as the datasets cover different time periods, and the Census constitutes a theoretical survey of the entire population while the American Community Survey is just a sample. The reason for the use of different data sets is that many of the data indicators included in this section are not available from the 2010 Census.

\section{DEMOGRAPHIC CHARACTERISTICS}

\section{Age Distribution}

According to the 2008-2012 American Community Survey, there are currently 1.6 million persons over the age of 65 living in the state of Illinois. This constitutes $12.6 \%$ of the total population. These figures are fairly consistent with national trends, which report $13.3 \%$ of the population aged 65 or older (the "young old"), $6.1 \%$ aged 75 or older (the "middle old"), and 1.8\% aged 85 or older (the "old old"). (See Table 2).

Table 2: State of Illinois Older Adult Population Distribution

\begin{tabular}{|l|r|r|}
\hline Age & Population & Percent of Total Population \\
\hline $65+$ & $1,615,806$ & $12.6 \%$ \\
\hline $75+$ & 756,608 & $5.9 \%$ \\
\hline $85+$ & 230,829 & $1.8 \%$ \\
\hline
\end{tabular}

Data Source: 2008-2012 Five-Year American Community Survey

Age distribution varies from county to county across Illinois. Counties with above-average concentrations of older adult residents tended to be clustered in four main areas within the state: (1) the northwest corner, east of Dubuque, IA, (2) mid-state north of Peoria, IL, (3) the western most portion of the state along the Mississippi River, and (4) the southeast corner of the state along the Illinois-Indiana border. Many of these counties are rural in character. Conversely, the counties with the lowest proportion of older adult residents tended to be located adjacent to Chicago including Kendall, Kane, and Will counties. (See Table 3 and Figures 7A, 7B, and 7C). 
Table 3: Counties with the Highest Proportions of Older Adult Residents

\section{Residents Age 65+}

\begin{tabular}{|l|r|r|}
\hline County & Number & Percent \\
\hline Jo Daviess & 4,873 & $21.5 \%$ \\
Hardin & 923 & $21.4 \%$ \\
Carroll & 3,282 & $21.4 \%$ \\
Henderson & 1,542 & $21.2 \%$ \\
Gallatin & 1,180 & $21.1 \%$ \\
\hline Illinois & $1,615,806$ & $12.6 \%$ \\
\hline
\end{tabular}

See Appendix $\mathrm{K}$ for figures for all counties.

\section{Residents Age 75+}

\begin{tabular}{|l|r|r|}
\hline County & Number & Percent \\
\hline White & 1,557 & $10.6 \%$ \\
Ford & 1,447 & $10.3 \%$ \\
Stark & 604 & $10.1 \%$ \\
Carroll & 1,534 & $10.0 \%$ \\
Marshall & 1,257 & $10.0 \%$ \\
\hline Illinois & 756,608 & $5.9 \%$ \\
\hline
\end{tabular}

\section{Residents Age 85+}

\begin{tabular}{|l|r|r|}
\hline County & Number & Percent \\
\hline Ford & 534 & $3.8 \%$ \\
Schuyler & 285 & $3.8 \%$ \\
Stark & 221 & $3.7 \%$ \\
Pike & 592 & $3.6 \%$ \\
Marshall & 427 & $3.4 \%$ \\
\hline Illinois & 230,829 & $1.8 \%$ \\
\hline
\end{tabular}

Figure 7A: Proportion of Residents Age 65+ by County

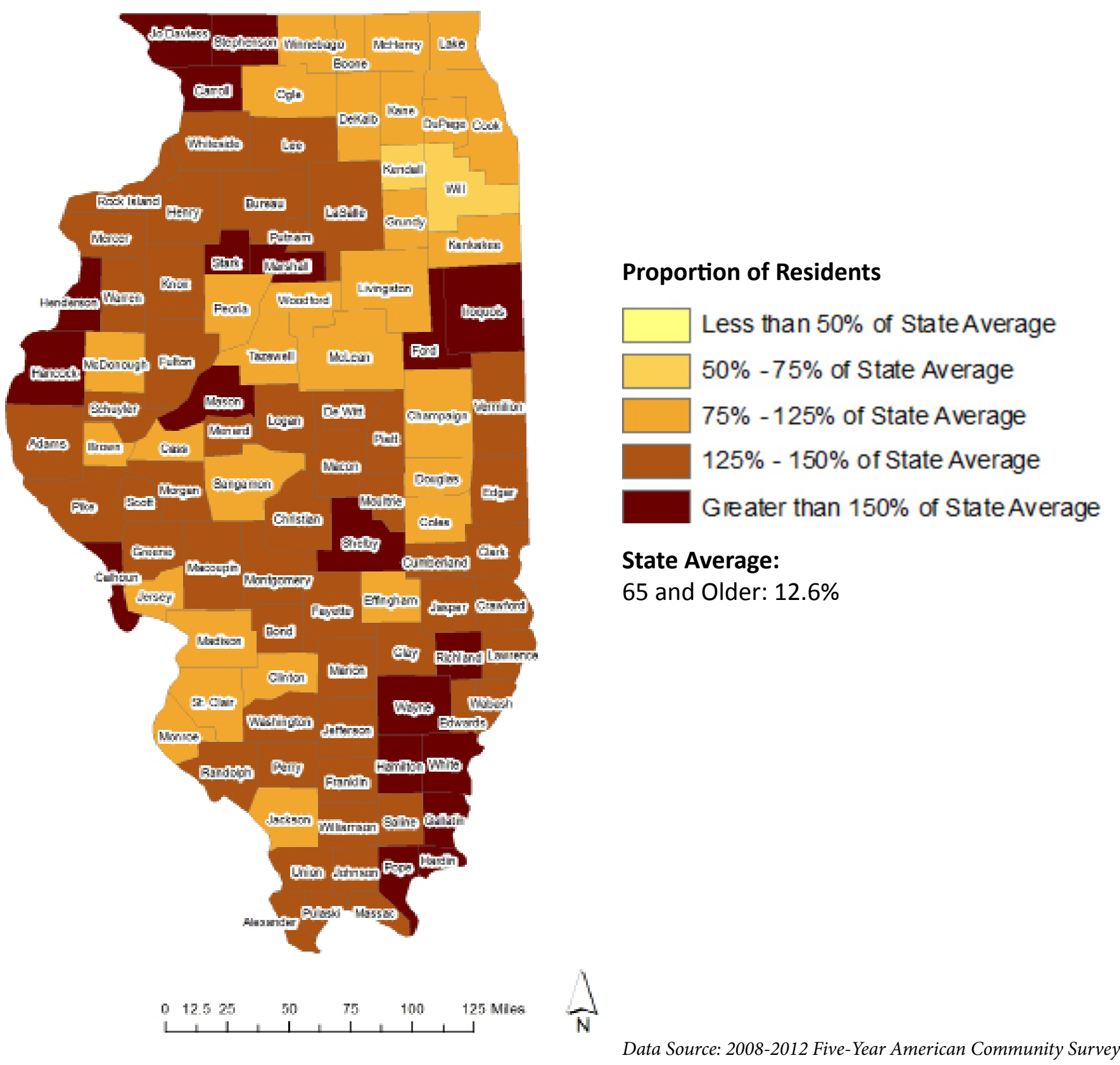


Figure 7B: Proportion of Residents Age 75+ by County

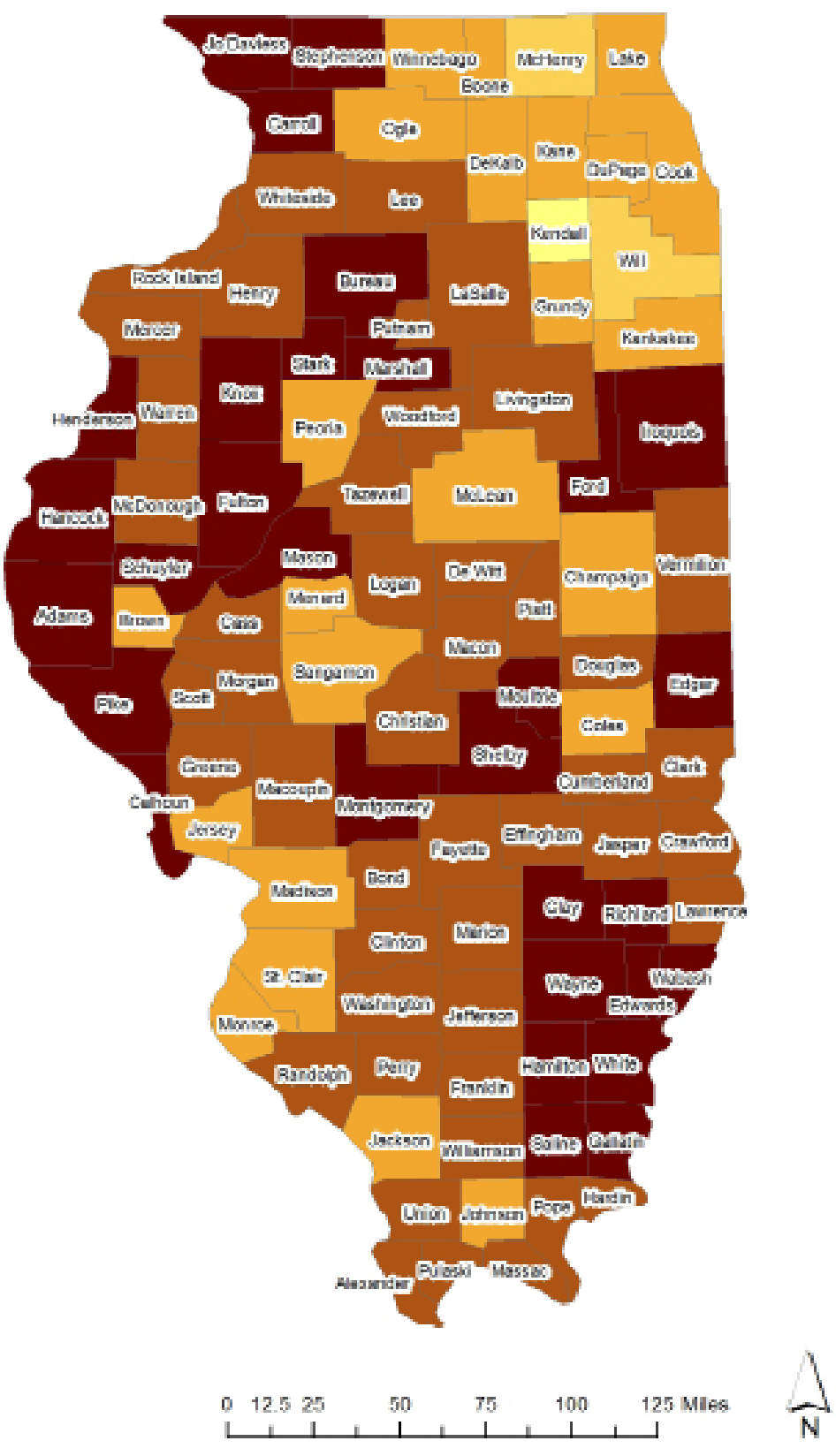

Figure 7C: Proportion of Residents Age 85+ by County

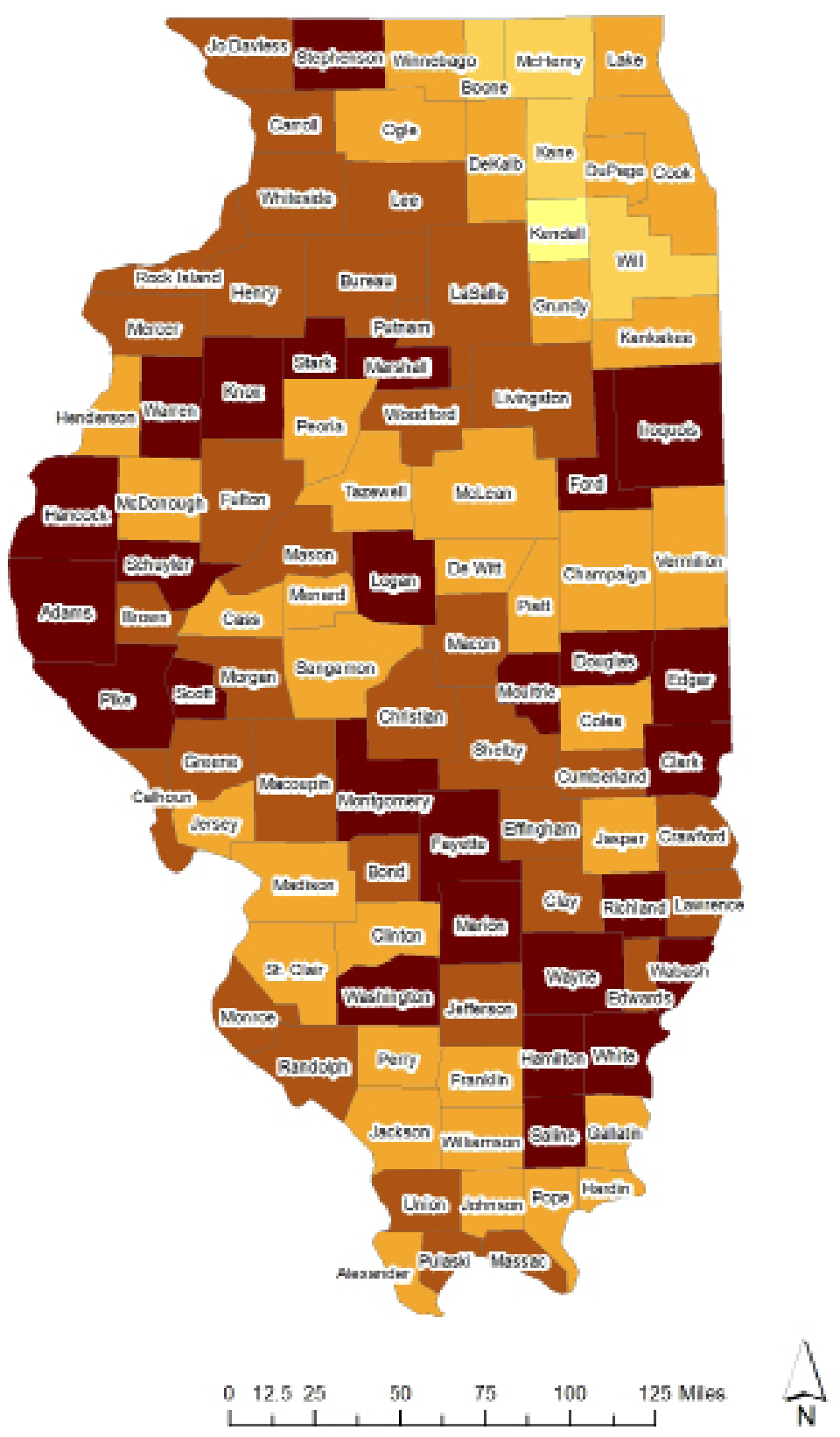

\section{Proportion of Residents}

\begin{tabular}{l}
\hline Less than $50 \%$ of State Average \\
$50 \%-75 \%$ of State Average \\
$75 \%-125 \%$ of State Average \\
$125 \%-150 \%$ of State Average \\
Greater than $150 \%$ of State Average
\end{tabular}

State Average:

65 and Older: $12.6 \%$

75 and Older: $5.9 \%$

85 and Older: $1.8 \%$ 


\section{Older Adults Living Alone}

Independent living can become increasingly challenging as individuals age and may require additional assistance with daily life tasks. Older adults living alone that have limited mobility are at a higher risk of lacking basic access to needed medical services, grocery stores, and other amenities. In Illinois, $46.3 \%$ of residents aged 65 and older live alone. This number increases to $56.1 \%$ for the population aged 75 and older. Areas with large numbers of older adults living alone rather than with other individuals or family members may indicate a higher local need for human and transportation services. However, high rates of independent living could reflect local conditions that are favorable to aging-in-community such as good transit access, walkable communities, or an abundance of affordable housing located near shopping and other services. In Illinois, the counties with high proportions of older adult residents tended to be rural counties that experienced population loss over the past ten years. The high concentrations of older adults living alone in these counties likely reflects a less geographically mobile older adult population left behind in counties shrinking, in part due to economic conditions, rather than areas attracting new older adult residents drawn by amenities and housing availability. (See Table 4 and Figure 8).

Table 4: Counties with the Highest Proportions of those 65+ Living Alone

\begin{tabular}{|l|r|r|}
\hline County & Number & Percent \\
\hline Effingham & 2,100 & $57.3 \%$ \\
Pulaski & 450 & $57.2 \%$ \\
Massac & 968 & $56.9 \%$ \\
Hardin & 329 & $53.6 \%$ \\
Knox & 3,524 & $53.6 \%$ \\
\hline Illinois & 474,036 & $46.3 \%$ \\
\hline
\end{tabular}

See Appendix L for figures for all counties.
Figure 8: Proportion of Residents Age 65+ Living Alone

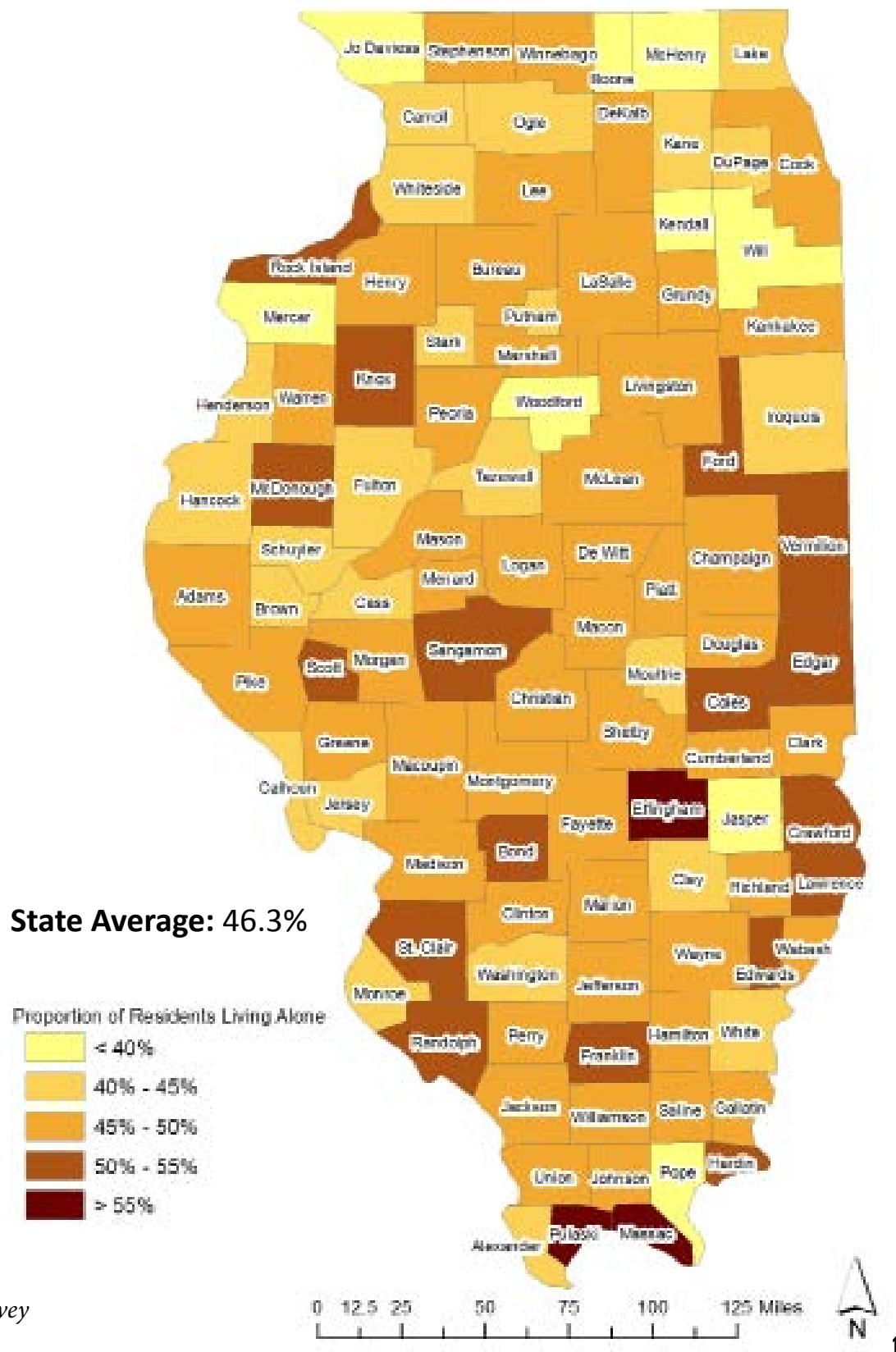




\section{Age \& Disability}

Disability and age are strongly related, as is one's need for additional social services. $10.3 \%$ of the Illinois population reports having a physical, emotional, or mental disability. This number is higher among the older adult population, increasing to $35 \%$ of all those aged 65 and older, and $49 \%$ of all those 75 and older. Specific to one's housing needs, $5 \%$ of the Illinois state population aged 18 and older reports having an independent living difficulty, meaning that due to a physical, mental, or emotional condition, they had difficulty "doing errands alone such as visiting a doctor's office or shopping" (US Census Bureau). Much like other disability types, this figure increases dramatically for the older adult population. Sixteen percent of those aged 65 and older and $25 \%$ of those 75 and older in Illinois report an independent living difficulty. As the share of the older adult population grows, those requiring supportive living and transportation services will increase in tandem. (See Table 5 and Figure 9).

Table 5: Counties with the Highest Proportions of Residents with a Reported Disability

\begin{tabular}{|l|r|r|}
\hline County & Number & Percent \\
\hline Hardin & 1,256 & $30 \%$ \\
Alexander & 1,752 & $23 \%$ \\
Pope & 927 & $22 \%$ \\
Gallatin & 1,197 & $22 \%$ \\
Pulaski & 1,200 & $20 \%$ \\
\hline Illinois & $1,301,381$ & $10.3 \%$ \\
\hline
\end{tabular}

See Appendix M for figures for all counties.
Figure 9: Percent of Persons with a Disability by County

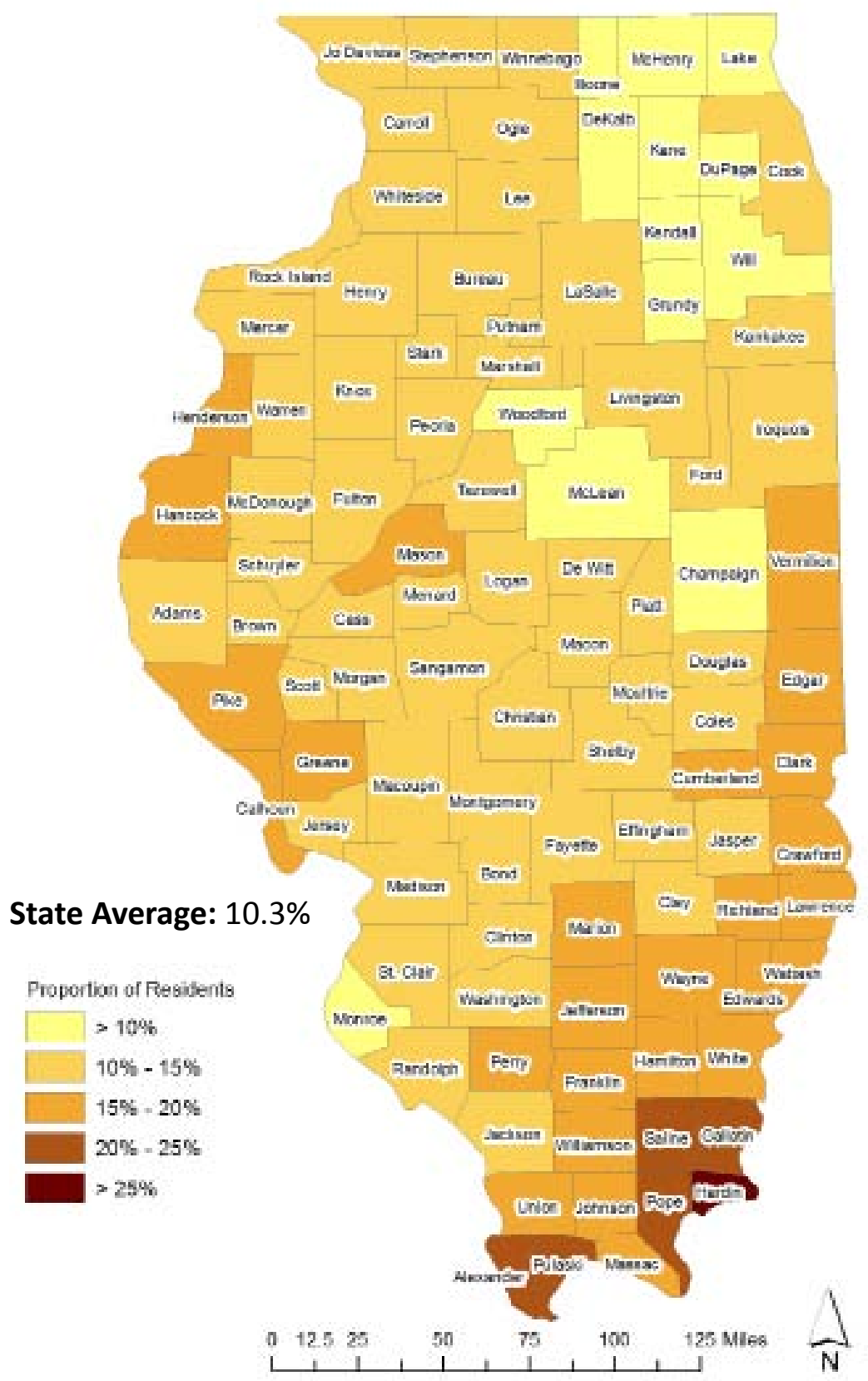




\section{HOUSING CHARACTERISTICS}

Housing conditions and availability play a major role in both the quality of life and mobility of the older adult population. Housing often comprises the largest share of monthly household expenditure and can serve as a central financial asset. According to a 2014 AARP study of livability, the majority (87\%) of individuals surveyed aged 65 and older would prefer to live in their current community as they age (Hammell et al, 2013). In order for older adult residents to age-in-community, local conditions must be conducive to supporting a population that will require additional services and mobility support.

\section{Where do Illinois' Older Adults Live?}

Similar to the general Illinois population, the majority of Illinois residents aged 65 and older live in single family attached or detached homes. This is consistent with the national tendency for a very small fraction of older adults to live in housing specifically designed and operated as older adult housing. At $70.7 \%$, the proportion of those 65 and older in single family homes is slightly higher than the total Illinois population at $66.8 \%$. Older Illinois residents also outpace the general population in the proportion of householders in buildings containing 20 or more units. This likely reflects the shift toward extended residential care facilities as individuals age. (See Table 6).

Table 6: Housing Typologies

\begin{tabular}{|l|l|r|r|r|}
\hline & $\begin{array}{l}\text { One-Unit Building } \\
\text { (attached/detached) }\end{array}$ & $\begin{array}{l}\text { 2-19 Units in Build- } \\
\text { ing }\end{array}$ & $\begin{array}{l}\text { 20+ Units in Build- } \\
\text { ing }\end{array}$ & $\begin{array}{l}\text { Mobile Home, RV, } \\
\text { Boat, Van, Etc. }\end{array}$ \\
\hline All Householders & $66.8 \%$ & $21.3 \%$ & $9.7 \%$ & $2.5 \%$ \\
\hline Householders Aged 65+ & $70.7 \%$ & $13.4 \%$ & $2.8 \%$ \\
\hline
\end{tabular}

Data Source: 2008-2012 Five-Year American Community Survey

\section{What Housing Options are Available to Older Adults?}

The type of housing available throughout Illinois varies from community to community. Urban Cook County contains fewer single family homes and more multi-family buildings compared to its more rural and suburban counterparts. Conversely, recently built-out areas on the rural-urban fringe such as Kendall County almost exclusively contain single family homes, while more rural parts of the state tend have high proportions of mobile housing units. (See Tables and Figures 7A, 7B, and 7C). The availability of housing variety plays a role in the ability of older adults to stay in their communities as they age. Many older adults choose to downsize from their large single-family homes they lived in for decades out of a change in taste or inability to maintain a larger structure. The availability of smaller housing units such as accessory dwelling units (often referred to as "granny flats"), older adult apartments, or multi-family dwelling units will impact whether or not older adults must move outside of their current communities to find other housing options. Furthermore, a lack of housing options may serve to strand older adults in homes they otherwise can no longer maintain by themselves.

To understand the range of housing options available to older adults as they age, we examined data on the existing building stock in each county. Cook County contained the highest proportion of multifamily units, driven largely by high building density in Chicago. Many of the other counties with high proportions of multifamily units contained college campuses. Counties with high proportions of single family homes tended to be more suburban or rural in nature. The lack of smaller units may pose challenges as these communities age and households seek to downsize into smaller homes that are easier for older adults individuals to maintain. 
Table 7A: Proportion of Single Unit Attached/Detached Homes

\begin{tabular}{|l|r|r|}
\hline County & Number & Percent \\
\hline Kendall & 34,829 & $92.1 \%$ \\
Marshall & 4,644 & $91.2 \%$ \\
Piatt & 5,766 & $89.7 \%$ \\
Stark & 2,175 & $89.2 \%$ \\
McHenry & 96,857 & $88.9 \%$ \\
\hline Illinois & $1,478,794$ & $31.0 \%$ \\
\hline
\end{tabular}

Table 7B: Proportion of Multi-Unit Homes (Two or More Units)

\begin{tabular}{|l|r|r|}
\hline County & Number & Percent \\
\hline Cook & 991,973 & $51.3 \%$ \\
Champaign & 26,872 & $33.9 \%$ \\
Jackson & 6,884 & $29.3 \%$ \\
DeKalb & 10,591 & $27.9 \%$ \\
McLean & 17,074 & $26.8 \%$ \\
\hline Illinois & $3,176,592$ & $66.5 \%$ \\
\hline
\end{tabular}

Table 7C: Proportion of Mobile Homes

\begin{tabular}{|l|r|r|}
\hline County & Number & Percent \\
\hline Johnson & 1,290 & $23.3 \%$ \\
Wayne & 1,844 & $23.1 \%$ \\
Pulaski & 715 & $22.6 \%$ \\
Hardin & 531 & $22.0 \%$ \\
Pope & 526 & $20.5 \%$ \\
\hline Illinois & 140,402 & $2.7 \%$ \\
\hline
\end{tabular}

(Note that the remaining units in Illinois are classified as, boats, RVs, vans, and other units).

See Appendix $\mathrm{N}$ for figures for all counties.

Data Source: 2008-2012 Five-Year American Community Survey 
Figure 10A: Proportion of Single Unit Homes

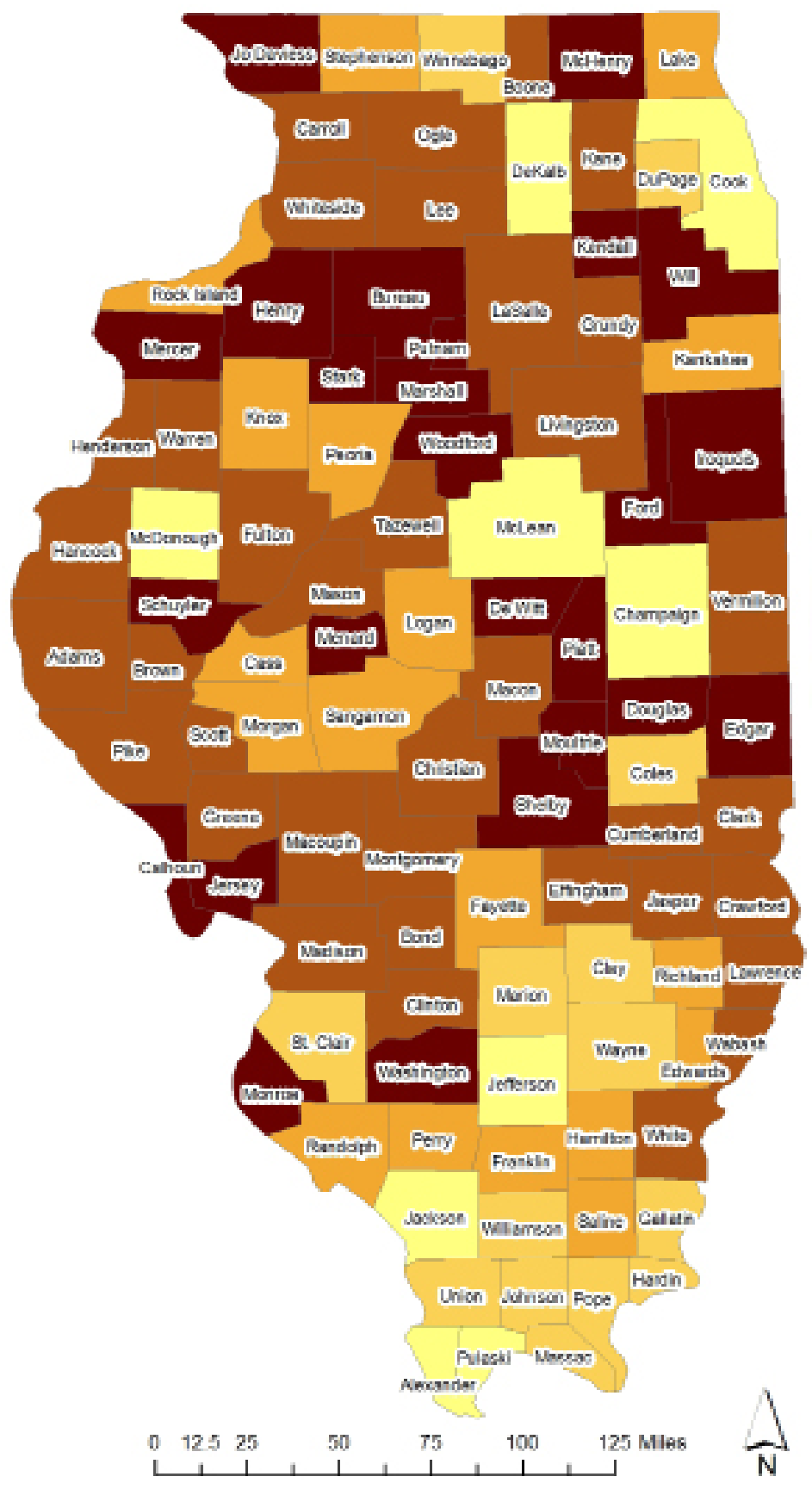

Figure 10B: Proportion of Multi-Unit Homes

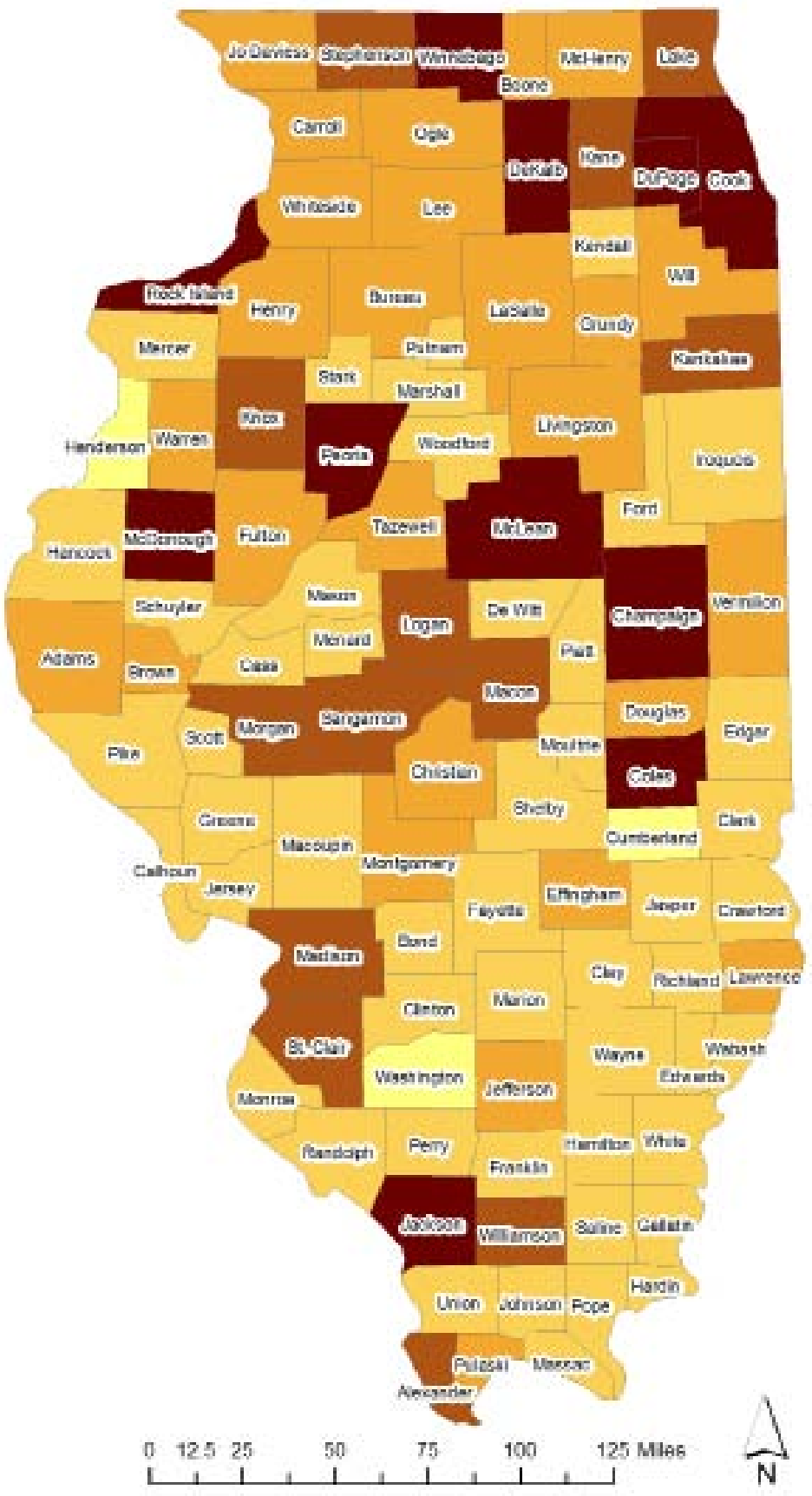

\section{Multi-Unit}

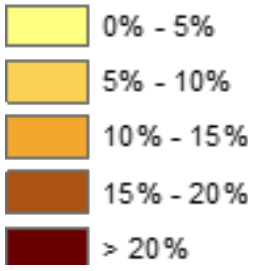

State Average: Multi-Unit: $31.0 \%$

State Average: Single Unit: $66.5 \%$

Data Source: 2008-2012 Five-Year American Community Survey 
Figure 10C: Proportion of Mobile Homes

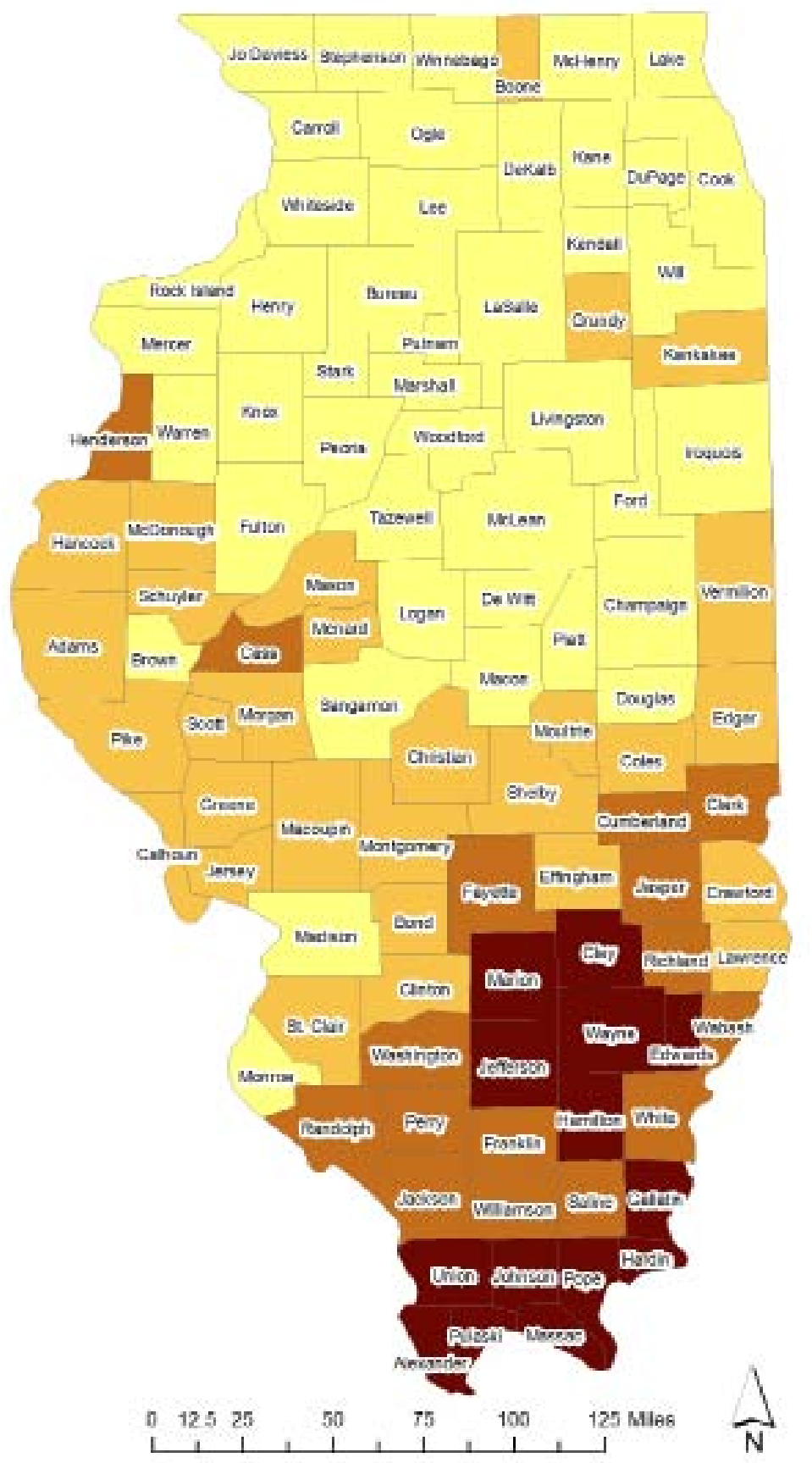

\section{Mobile Homes}

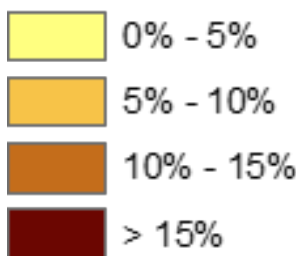

State Average: Mobile Homes: $2.7 \%$

Data Source: 2008-2012 Five-Year American Community Survey 


\section{Do Older Adults Rent or Own?}

In Illinois, roughly $68 \%$ of householders own their homes, while $32 \%$ are renters. The proportion of homeowners is notably higher among the older adult population, where it reaches $79 \%$. This likely reflects basic course-of-life trends. As people age, they accumulate more wealth which facilitates home buying. Where we do observe a significant shift in homeownership is among the population aged 85 or older. While over $80 \%$ of individuals aged 65 to 84 own their homes, this figure drops by $10 \%$ for the population aged 85 and older. This might reflect trends in home downsizing, sometimes preempted by the need for additional care. At this age, some older adults may sell the family home and downsize to a smaller apartment or into assisted living or another specifically older adult facility. Other older adults might at this age move in with children or other family members, thus making them part of those respective households rather than their own individual households as counted by the Census. (See Table 8).

Table 8: Older Adults \& Housing Tenure

\begin{tabular}{|l|r|r|}
\hline Age of Householder & Percent Homeowners & Percent Renters \\
\hline $65-74$ & $81.6 \%$ & $18.4 \%$ \\
\hline $75-84$ & $80.1 \%$ & $19.9 \%$ \\
\hline $85+$ & $70.6 \%$ & $29.4 \%$ \\
\hline All ages & $68.0 \%$ & $32.0 \%$ \\
\hline
\end{tabular}

Data Source: 2008-2012 Five-Year American Community Survey

\section{Mortgage Status}

In Illinois, $69 \%$ of homeowners possess a mortgage on their homes while $31 \%$ own their homes outright. Not surprisingly, the proportion of homeowners that own their homes outright without a mortgage is significantly higher among the older adult population as households pay down the typical 30-year mortgage over time. (See Table 9).

Table 9: Older Adults \& Mortgage Status

\begin{tabular}{|l|r|r|}
\hline Age of Householder & With Mortgage & Without Mortgage \\
\hline $65-74$ & $43.8 \%$ & $56.2 \%$ \\
\hline $75+$ & $18.3 \%$ & $81.7 \%$ \\
\hline All ages & $68.9 \%$ & $31.1 \%$ \\
\hline
\end{tabular}

Data Source: 2008-2012 Five-Year American Community Survey

\section{Is Housing Affordable to Older Adults?}

Housing constitutes a large if not the largest monthly expense among households of all ages. According to Department of Housing and Urban Development (HUD) thresholds, housing is deemed unaffordable if a household is devoting more than $30 \%$ of its income toward housing. In Illinois, older adult households exceeding the $30 \%$ threshold varied by location within the state and by housing tenure.

\section{Homeowners}

Among the $79 \%$ of older adult households that own their homes rather than rent, the proportion of costburdened households (those devoting $30 \%$ or more of household income to housing) was $30.1 \%$, which is consistent with trends among households of all ages. (See Table 10). Cost-burdened households were located disproportionally in the northeastern corner of the state, which reflects the region's high cost of living and real estate prices. McHenry and Lake Counties both reported a proportion of cost-burdened older adults that exceeded $125 \%$ of the state average. (See Figure 11). 
Table 10: Cost-Burdened Homeowners by Age

\begin{tabular}{|c|c|c|}
\hline & \multicolumn{2}{|c|}{$\begin{array}{r}\text { Percent of Income Devoted to Owner } \\
\text { Costs }\end{array}$} \\
\hline Age of Householder & $30 \%$ or more & $35 \%$ or more \\
\hline $65+$ & $30.1 \%$ & $23.9 \%$ \\
\hline All ages & $30.9 \%$ & $23.8 \%$ \\
\hline
\end{tabular}

Data Source: 2008-2012 Five-Year American Community Survey

Figure 11: Proportion of Cost-Burdened Homeowners Age 65+

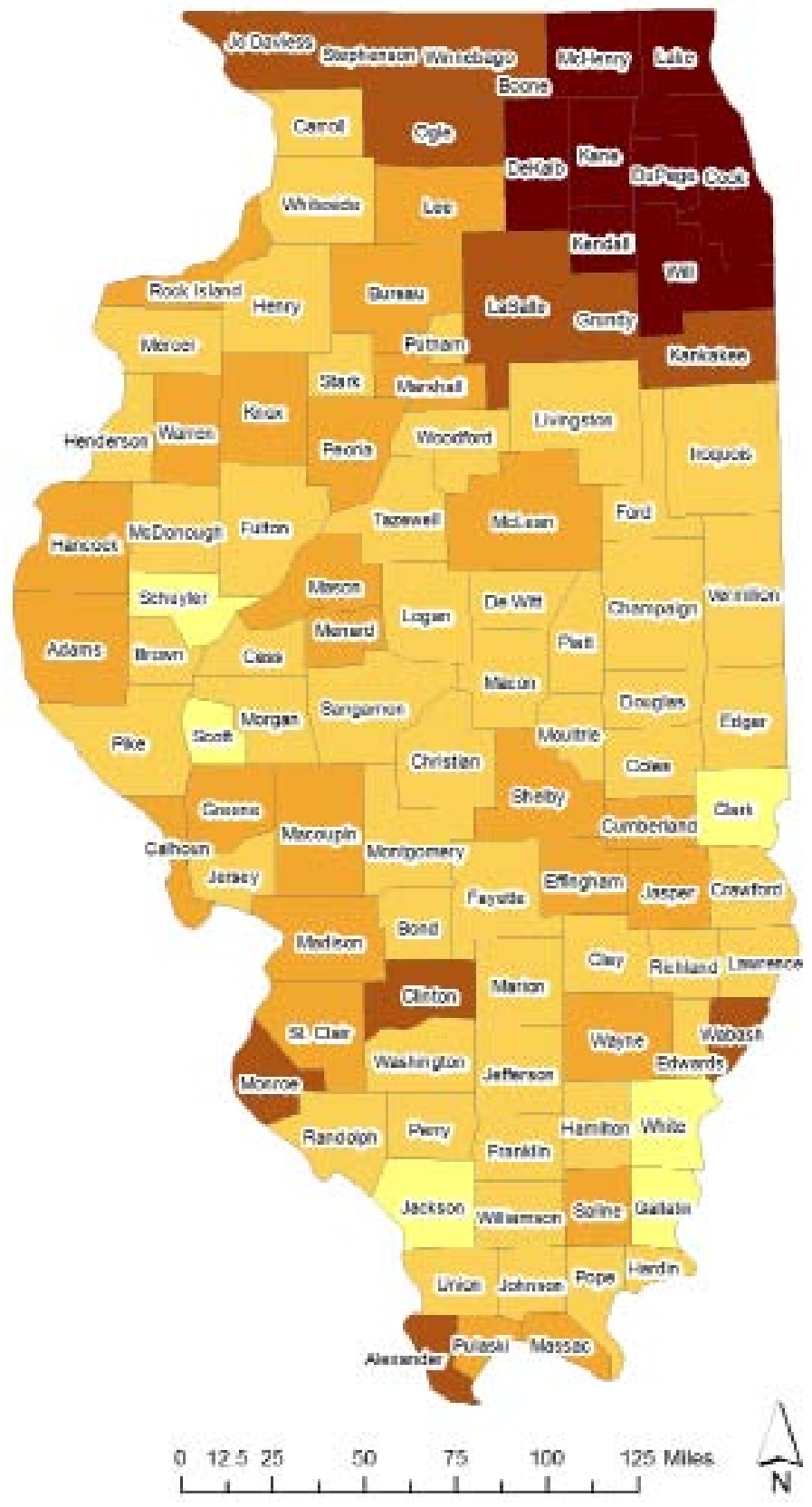

Table 11: Counties with the Highest Proportion of Cost-Burdened Older Adult Homeowners

\begin{tabular}{|l|r|}
\hline County & $\begin{array}{r}\text { Proportion of } \\
\text { Residents Age 65+ }\end{array}$ \\
\hline Lake & $38.5 \%$ \\
McHenry & $38.0 \%$ \\
Cook & $37.6 \%$ \\
Kane & $37.0 \%$ \\
Will & $34.7 \%$ \\
\hline Illinois & $30.1 \%$ \\
\hline
\end{tabular}

See Appendix $O$ for figures for all counties.

\section{Proportion of Homeowners}

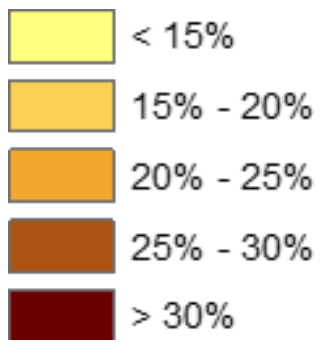

State Average:

All Householders: $30.1 \%$

Householders Age 65+: $30.9 \%$ 


\section{Renters}

Older adult households burdened by housing costs are much more prevalent among renters. In Illinois, $48 \%$ of all renters devote more than $30 \%$ of their income toward rent, and $40 \%$ devote more than $35 \%$. These households are considered to be cost-burdened per HUD thresholds. The proportion of cost-burdened renters is higher among the older adult population, with $56 \%$ of those aged 65 or older devoting more than $30 \%$ of their income toward housing, and $46 \%$ devoting more than 35\%. (See Table 12). This trend stems from a variety of factors including the high cost of assisted living facilities, the fixed incomes of retired individuals, and the propensity to sell one's home and downsize later in life. It is important to note that there are fewer renters among the older adult population, as a higher proportion resided in owner-occupied homes (31\% as compared to $79 \%$ ).

Table 12: Rent-Burdened Households

\begin{tabular}{|l|r|r|}
\hline & \multicolumn{2}{|l|}{ Percent of Income Devoted to Rent } \\
\hline Age of Householder & $\mathbf{3 0 \%}$ or more & $\mathbf{3 5 \%}$ or more \\
\hline $65+$ & $55.9 \%$ & $46.4 \%$ \\
\hline All ages & $47.6 \%$ & $39.5 \%$ \\
\hline
\end{tabular}

Data Source: 2008-2012 Five-Year American Community Survey

Patterns of rent-burdened older adults had much less of a geographic component when compared to costburdened households. Rent-burdened older adults still tended to be concentrated in the high-cost Chicago metropolitan region, but the disparities are less severe. The highest proportion of rent-burdened older adults was reported in Pulaski County. However, Pulaski County has a small population, and a very small population of older adult renters, which serves to increase margin of error and decrease the reliably of this figure. (See Table 13 and Figure 12).

Table 13: Counties with the Highest Proportion of Burdened Renters Age 65+

\begin{tabular}{|l|r|}
\hline County & $\begin{array}{r}\text { Proportion of } \\
\text { Residents Age 65+ }\end{array}$ \\
\hline Pulaski & $72.5 \%$ \\
Kane & $66.8 \%$ \\
Will & $61.1 \%$ \\
Cook & $60.8 \%$ \\
Lake & $59.5 \%$ \\
\hline Illinois & $55.9 \%$ \\
\hline
\end{tabular}

Data Source: 2008-2012 Five-Year American Community Survey

See Appendix P for figures for all counties. 
Figure 12: Proportion of Cost-Burdened Renters Age 65+

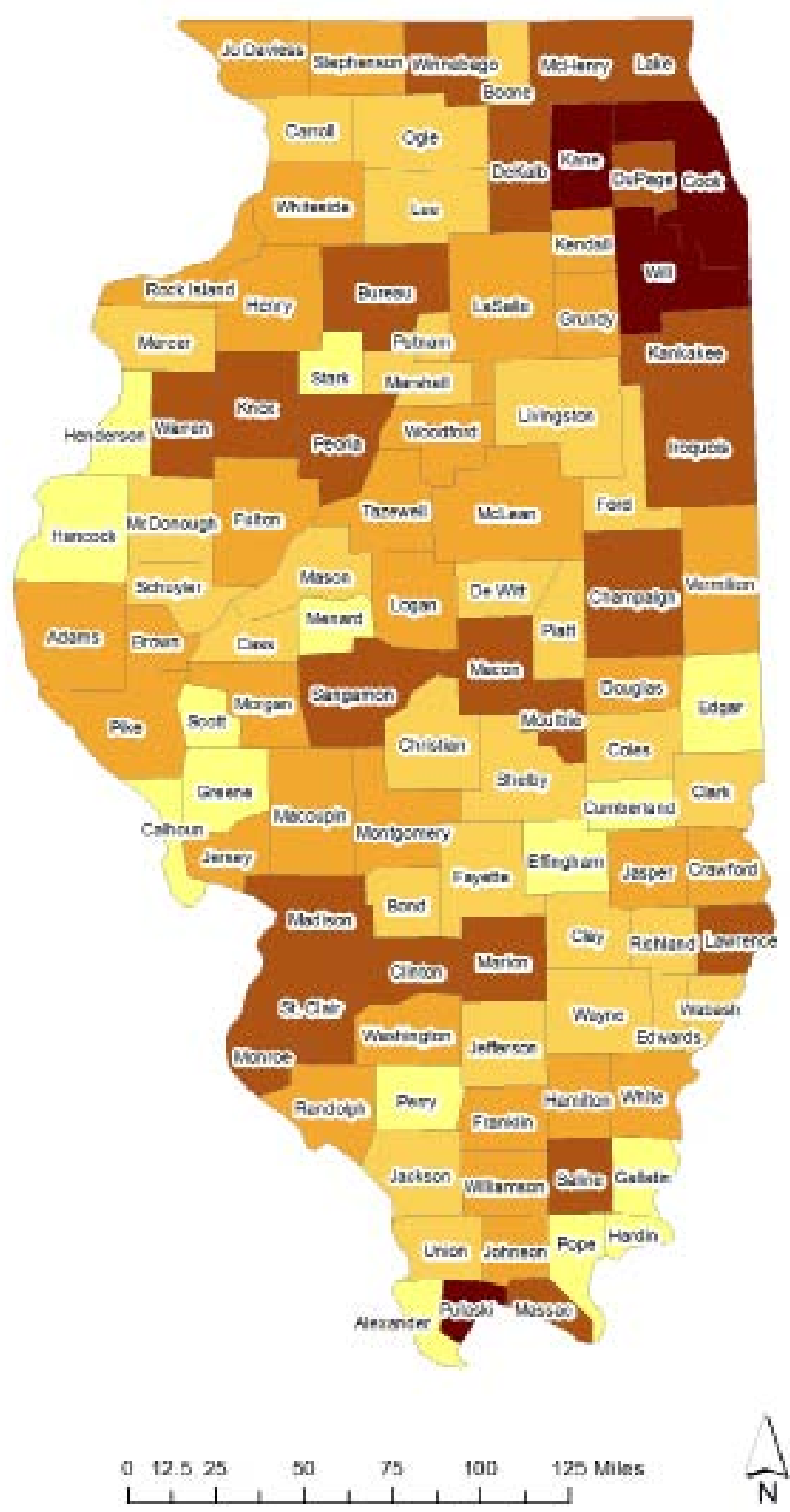

Proportion of Renters

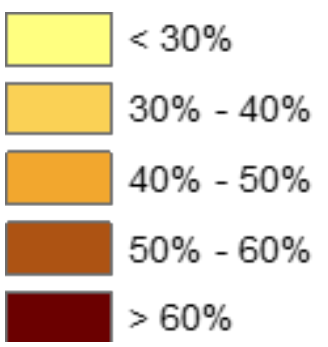

State Average:

All Renters: $47.6 \%$

Renters Age 65+: 55.9\%

Data Source: 2008-2012 Five-Year American Community Survey 


\section{TRANSPORTATION \& MOBILITY CHARACTERISTICS}

As the Baby Boom generation ages, older adults will constitute a greater share of Illinois drivers. Concurrently, a growing number of individuals are expected to outlive their ability to drive (by seven years for men and ten years for women on average) (Foley et al, 2002). According to the Insurance Institute for Highway Saftey (IIHS), crash involvement, injuries, and fatalities have declined in recent years at a faster rate among the older adult population than those that are middle-aged - a trend largely attributed to improved vehicle saftey and health among older adults. However, fatal crash involvements remained high for older adults when compared to middle-aged drivers, (1.117 per 100 million vehicle miles traveled for those age 35 to 54 compared to 2.691 for those 75-79, and 5.484 to those aged 80 and older) (IIHS, 2014). Given the number of older adults that may require alternative transportation, it is increasingly important to plan proactively for this fast-growing cohort. This will be particularly challenging in more rural and suburban regions of the state that lack the population density to support a fixed-route transit system.

\section{Mode of Transportation}

In order to understand the current mobility trends by state geography and by age, we examined mode of transportation data produced by the American Community Survey. However, it is important to note that these data are only available for trips to work. Given that a large proportion of the older adult population is no longer in the workforce, these data do not necessarily reflect the travel behavior of non-working older adults. (16.2\% of those age 65 and older are in the workforce compared to $64.5 \%$ of those age 16 or older according to 20082012 Five-Year American Community Survey Data). However, they do provide a good proxy for the types of transportation options that exist for area older adults.

The majority of work trips in Illinois were made by individuals driving alone. Individuals age 65 and older were less likely to commute via carpool or public transportation, but were more likely to work at home than the population as a whole. (See Table 14).

Table 14: Mode of Travel to Work by Age

\begin{tabular}{|l|r|r|r|r|r|}
\hline & Drove Alone & Carpooled & $\begin{array}{r}\text { Public } \\
\text { Transportation }\end{array}$ & $\begin{array}{r}\text { Walked } \\
\begin{array}{r}\text { Taxi, Motorcycle, } \\
\text { Bicycle, other }\end{array}\end{array} \begin{array}{r}\text { Worked at } \\
\text { Home }\end{array}$ \\
\hline All Commuters & $73.5 \%$ & $9.0 \%$ & $8.7 \%$ & $3.1 \%$ & $1.6 \%$ \\
\hline Commuters Age 65+ & $73.9 \%$ & $7.0 \%$ & $6.2 \%$ & $3.1 \%$ & $4.1 \%$ \\
\hline
\end{tabular}

Data Source: 2008-2012 Five-Year American Community Survey

\section{Public Transportation Usage}

Public transportation usage is conditional upon the presence of a public transportation system. The majority of public transportation users are located in the Chicago metropolitan area where the majority of the state's public transportation infrastructure and services are located. Champaign County also had a large proportion of public transportation riders, which again stems from the presence of transportation services as well as the built environment and high proportion of college students in the area.

Low transit usage was reported in the state's more rural and sparsely populated areas, which have few if any public transportation options. Eight counties reported no individuals commuting by public transportation: Calhoun, Clark, Greene, Jasper, Menard, Mercer, Moultrie, and Putnam Counties. (See Table 15 and Figure 13). 
Table 15: Transit Usage

\begin{tabular}{|l|r|r|}
\hline County & Number of Commuters & Percent of Commuters \\
\hline Cook & 420,010 & $17.7 \%$ \\
DuPage & 29,668 & $6.4 \%$ \\
Champaign & 5,997 & $6.1 \%$ \\
Lake & 14,235 & $4.2 \%$ \\
Will & 13,117 & $4.1 \%$ \\
\hline Illinois & 516,053 & $8.7 \%$ \\
\hline
\end{tabular}

See Appendix $Q$ for figures for all counties.

Figure 13: Proportion of Commutes via Public Transportation

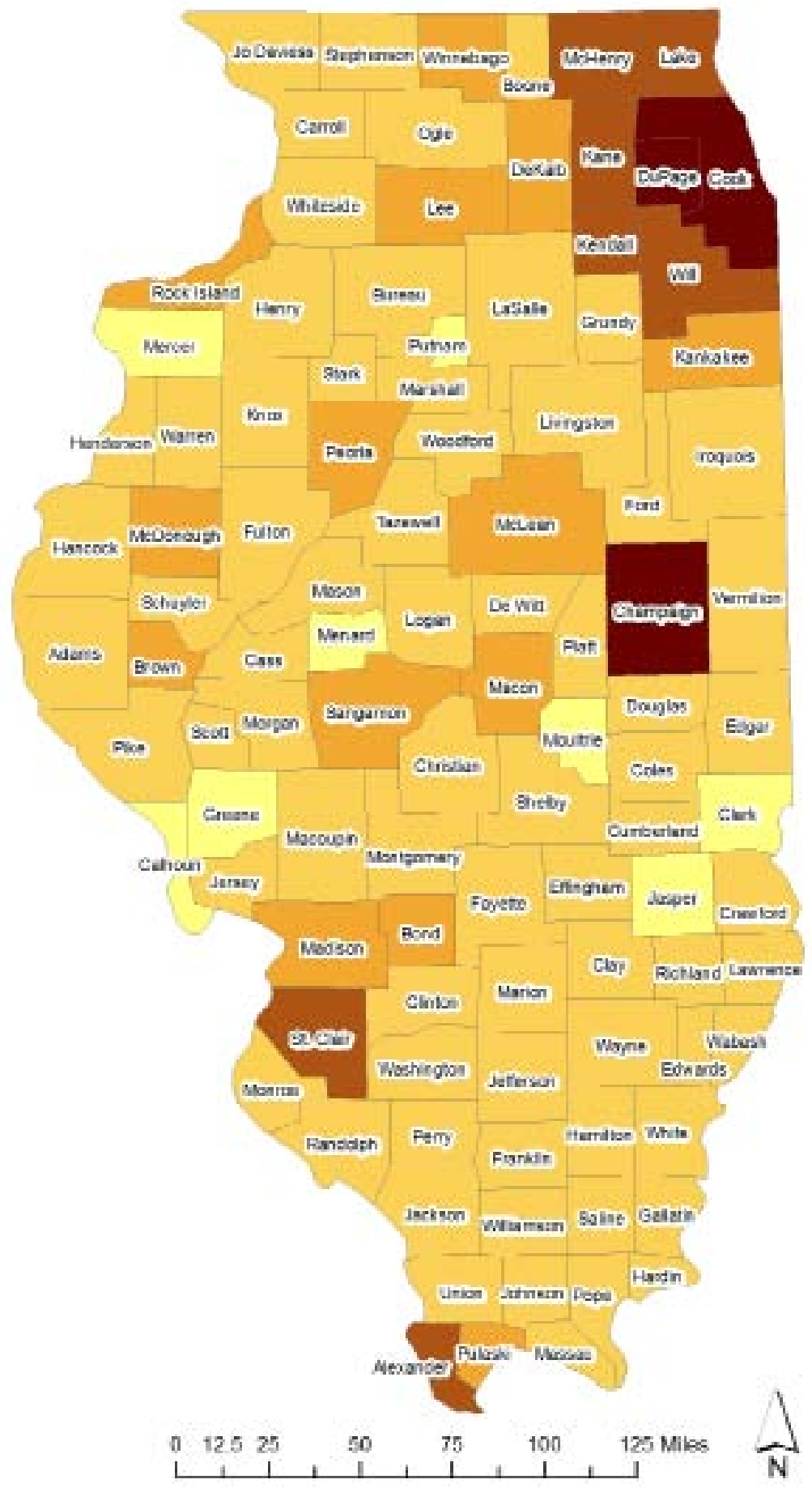

Proportion of Commuters

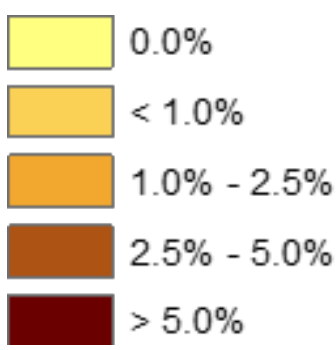

State Average: $8.7 \%$ 


\section{Carpooling}

Carpooling is more prevalent in rural areas and counties that lack public transportation options. High rates of carpool commuting were clustered in the more rural counties north of St. Louis, which may represent a pattern of local residents banding together to cut down commuting costs to jobs in or outside of St. Louis. This propensity to carpool, whether formally or informally organized, may make ridesharing a viable option among older adults with limited mobility. (See Figure 14 and Table 16).

Figure 14: Proportion of Commutes via Carpool

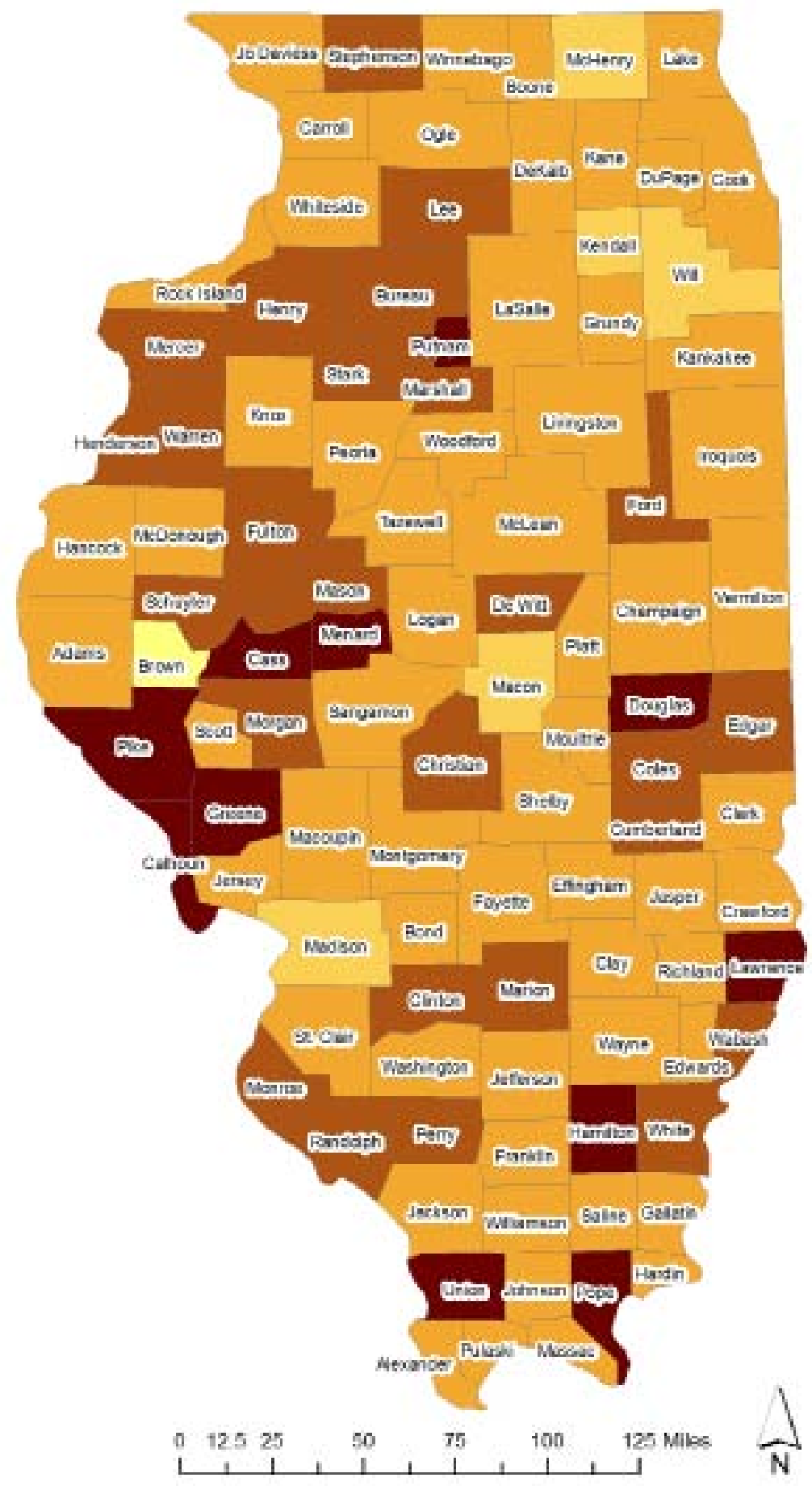

Table 16: Proportion of Commutes via Carpool

\begin{tabular}{|l|r|r|}
\hline County & $\begin{array}{r}\text { Number of } \\
\text { Commuters }\end{array}$ & $\begin{array}{r}\text { Percent of } \\
\text { Commuters }\end{array}$ \\
\hline Calhoun & 330 & $15.7 \%$ \\
Menard & 981 & $15.3 \%$ \\
Greene & 909 & $15.1 \%$ \\
Lawrence & 812 & $14.8 \%$ \\
Pope & 250 & $14.5 \%$ \\
\hline Illinois & 532,322 & $9.0 \%$ \\
\hline
\end{tabular}

Data Source: 2008-2012 Five-Year American Community Survey See Appendix $Q$ for figures for all counties.

\section{Proportion of Commuters}

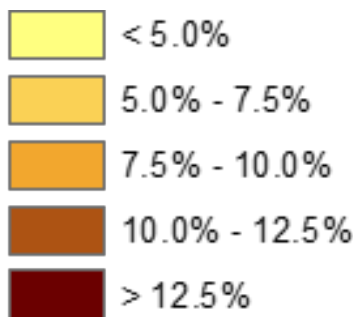

State Average: 9.0\% 


\section{Vehicle Availability}

In many parts of Illinois, particularly in rural and suburban counties, the default method of transportation is driving. As noted above, older adults are expected to outlive their driving years by an average of seven to ten years. To understand where this trend is already occurring, we examined data on vehicle availability per household, specifically, the proportion of older adult households that do not have access to a vehicle. These figures paint a twofold picture. While many older adults may be forced to give up a car due to disability or the high costs of owning and insuring a car, not owning a vehicle also can reflect a lifestyle choice predicated on the ability to travel by other means such as public transportation or walking. Not surprisingly, the largest proportion of older adults without vehicle access are located in Cook County, which has the region's most extensive public transportation system and high population density that places amenities like grocery stores within walking distance. (See Tables 17 and 18 and Figures 15A and 15B).

Table 17: Percent of All Households without a Vehicle

\begin{tabular}{|l|r|r|}
\hline County & Number & Percent \\
\hline Cook & 264,943 & $17.7 \%$ \\
Alexander & 299 & $14.7 \%$ \\
Pulaski & 144 & $11.6 \%$ \\
Champaign & 7,946 & $11.1 \%$ \\
Jackson & 2,105 & $10.7 \%$ \\
\hline Illinois & 50,9523 & $10.7 \%$ \\
\hline
\end{tabular}

(Note that the state figures are skewed by the large number of non-drivers in Cook County). Data Source: 2008-2012 Five-Year American Community Survey

See Appendix $\mathrm{R}$ for figures for all counties.

Table 18: Percent of Householders Age 65+ without a Vehicle

\begin{tabular}{|l|r|r|}
\hline County & Number & Percent \\
\hline Cook & 97,870 & $24.6 \%$ \\
Pulaski & 144 & $18.3 \%$ \\
Massac & 290 & $17.0 \%$ \\
Rock Island & 2,365 & $14.6 \%$ \\
St. Clair & 3,142 & $14.0 \%$ \\
\hline Illinois & 166,497 & $16.3 \%$ \\
\hline
\end{tabular}

(Note that the state figures are skewed by the large number of non-drivers in Cook County). Data Source: 2008-2012 Five-Year American Community Survey

See Appendix $\mathrm{R}$ for figures for all counties. 
Figure 15A: Proportion of Households without a Vehicle, All Ages

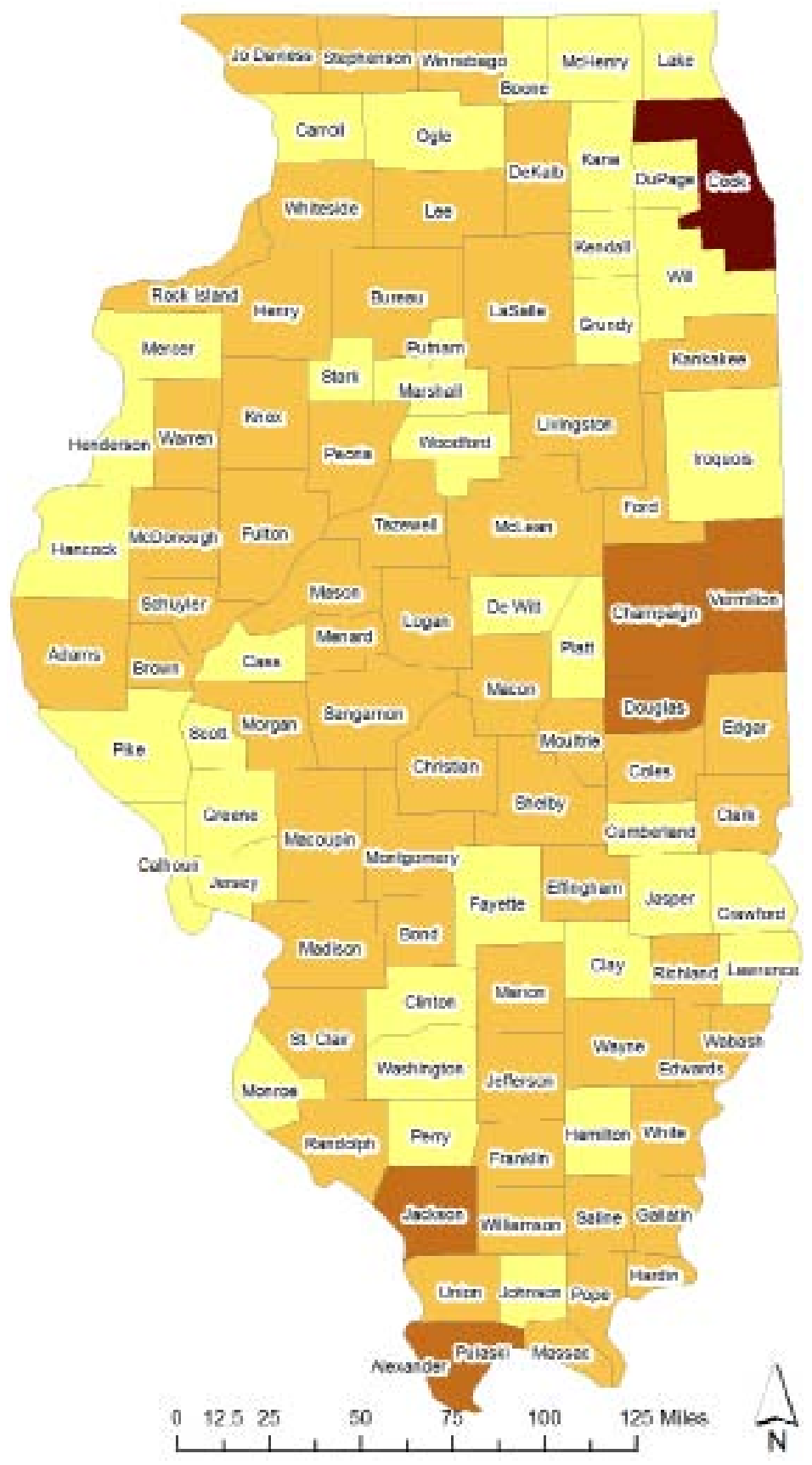

Figure 15B: Proportion of Households without a Vehicle, Age 65+

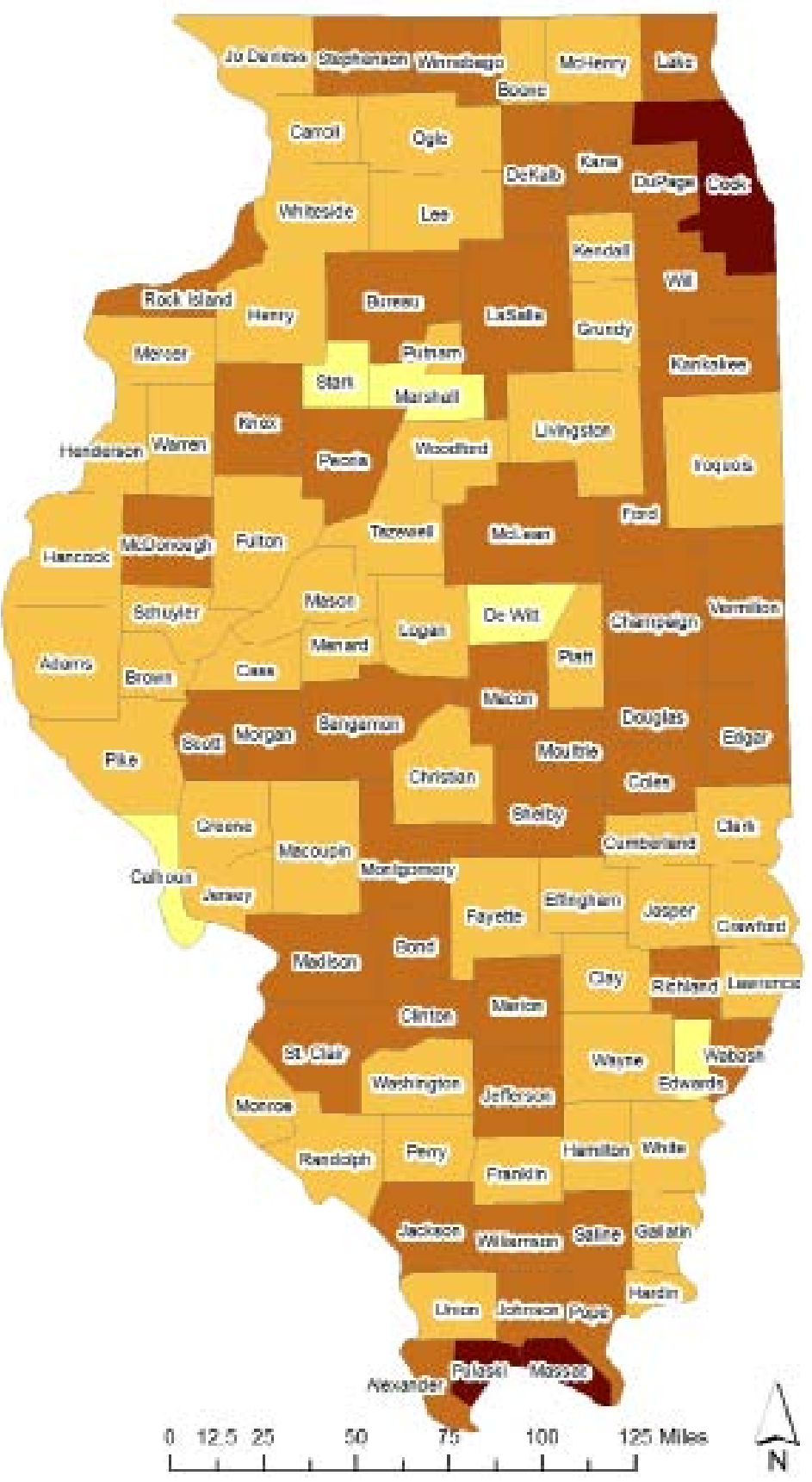

Data Source: 2008-2012 Five-Year American Community Survey

\section{Proportion of Households}

\begin{tabular}{l}
\hline \\
$\square .0 \%-5.0 \%$ \\
$5.0 \%-10.0 \%$ \\
$10.0 \%-15.0 \%$ \\
$>15.0 \%$
\end{tabular}

State Average:

All Households: $10.7 \%$

Age 65+: 16.3\% 


\section{Transit Availability}

Use of public transportation by older adults hinges largely on its availability. The majority of downstate counties in Illinois provide demand-response transportation service for the general public to and from any location within each county, usually in the form of a dial-a-ride or other similar service. Five counties-Calhoun, Christian, Greene, Henderson, and Jersey-do not currently have funded public transportation services. Several downstate counties provide public transportation in certain locations, but not the entire county. These may include demand-response systems serving a limited service area, or fixed or variable route bus services within certain municipalities or jurisdictions. These counties include Adams, Knox, Madison, McDonough, St. Clair, Stevenson, and Winnebago. The six counties in the urbanized Chicago metropolitan region (Cook, DuPage, Kane, Lake, McHenry, and Will) have extensive public transit infrastructure via the Chicago Transit Authority, Metra, and Pace Bus. Non fixed-route service including Call-n-Ride and vanpool services are available in certain locations throughout the Chicagoland region. Nine counties provide both countywide demand-response service and service in specific municipalities. These include Boone, Champaign, DeKalb, Kankakee, Macon,

Peoria, Rock Island, Sangamon, and Vermilion counties.

Figure 16: Public Transit Availability by County

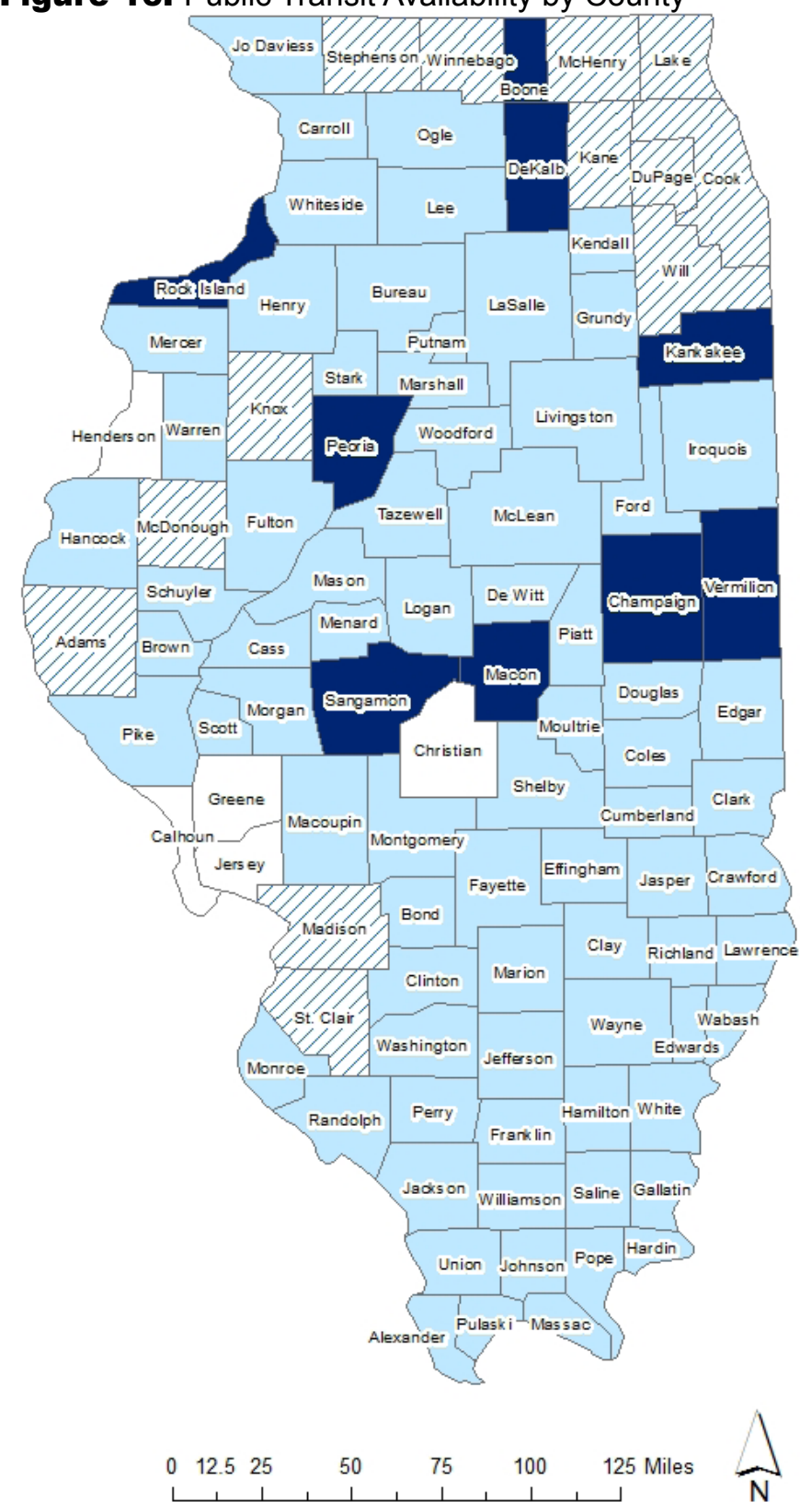

Figure 16 depicts, at the county level, publicly-funded transportation available to the general public throughout Illinois. Some counties and municipalities provide more extensive service to qualifying residents such as seniors, the disabled, and/or low-income residents.

\author{
Countywide Public Transportation \\ $\square$ No Countywide Public Transportation \\ C. Public Transporation in Certain Locations Only \\ Public Transportation in Municipal Locations and Countywide
}

Data Sources: Illinois Rural Transit Assistance Center, HSTP Plans, and TRANPRO Information Management System, Urban Transportation Center at the University of Illinois at Chicago 


\section{SECTION 3: CURRENT HUMAN SERVICES TRANSPORTATION PLANNING PRACTICE IN ILLINOIS}

With the backdrop of Section 1's population projections, and Section 2's analysis of statewide older adults' housing, transportation and mobility characteristics, we will now look at the current state of HST planning in Illinois.

\section{HISTORY \& DESCRIPTION}

In 2003, Illinois' governor and General Assembly created the Interagency Coordinating Committee on Transportation (ICCT) to help provide disadvantaged Illinois citizens (including older adults and disabled persons) with broader and better coordinated transportation services. ICCT's mission paralleled several similar federal initiatives, including a 2004 Executive Order on Human Services Transportation that established the Federal Interagency Transportation Coordinating Council on Access and Mobility (CCAM) to simplify access to transportation for older adults, disabled persons, and low-income individuals. The CCAM launched the United We Ride initiative to help implement the Executive Order. Additionally, the federal transportation legislation, including the Safe, Accountable, Flexible, Efficient Transportation Equity Act: A Legacy for Users (SAFETEA-LU), enacted in 2005 required that by the end of 2007 all state transportation programs incorporate regionally planned human services transportation in a Human Services Transportation Plan (HSTP). Illinois complied with this deadline by publishing a Human Services Transportation report as part of the Illinois State Transportation Plan published in June 2007 and revised in December 2007.

The ICCT includes representatives from numerous state human services and related agencies - including the Illinois Department of Aging - and other key stakeholder organizations. Illinois' HSTP developed a framework for developing the plan and a process for human services transportation funding programs, providing for public involvement, and providing research and technical assistance for plan implementation. Much of this work was to be carried out by regional HSTP coordinators and regional HSTP planning organizations.

The statutorily required 2012 Illinois Long Range Transportation Plan reiterated "transportation for underserved populations such as the older adults, low-income and the persons with disabilities" (IDOT, 2012) as a policy factor to be considered in the development of the plan but without making any specific reference to human services transportation planning or the HSTP process established in 2007.

\section{CURRENT STATUS}

A range of different types of transportation services for older adults is being provided throughout Illinois. While it is not a purpose of this report to focus on the details of these transportation services, a general description of the options helps to provide overall context. Generally speaking, larger fixed route-type services and larger vehicles are more appropriate to cities and areas with higher levels of population density, while rural areas and areas of lower population density more often support demand response-type services and smaller vehicles.

Typical transportation options for older adults include:

- Public Transit/Fixed Route Service: Public transit agencies provide bus and/or rail services along established routes with set schedules on a non-reservation basis - also referred to as "public transportation" or "mass transit". Reduced rate fares and additional transportation services are often available for older 
adults and persons with disabilities. Information about routes, schedules, fares, and special services are typically available through the public transit agencies.

- Paratransit Service: Public transit, human service (including older adult-serving) organizations, and private agencies provide door-to-door or curb-to-curb transportation using mini-buses or small vans. Paratransit service often requires users to make advanced reservations but still offers a degree of flexibility and personalization in scheduling. Curb-to-curb service provides for passenger pick- up and delivery at the curb or roadside; door-to-door service offers a higher level of assistance by picking up passengers at the door of their homes and delivering them to the doors of their destinations. Paratransit and van services generally offer reduced fares for older adults and persons with disabilities, and some providers operate on a donation basis.

- Door-through-Door Service: Some human service agencies provide drivers or escorts who offer personal, hands-on assistance by helping passengers through the doors of their residences and destinations, as needed. This type of service includes several levels of assistance from opening doors and providing verbal guidance, to physical support. Persons with severe physical or mental disabilities typically use this type of service.

- Transportation Vouchers Programs: AAAs and other human service organizations often provide fare assistance programs that enable qualified persons to purchase vouchers for transportation services at a reduced rate. The vouchers are then used to pay for services from a participating transportation provider that can include public transportation, volunteer programs, or taxis and other private companies. Applications for these programs are required. Participants are responsible for reserving and securing the services they need.

- Taxi Service: Passengers activate this service by calling a dispatcher to request a ride between locations of their choice. Trips usually can be scheduled in advance or on the spot. Some taxis are wheelchair accessible and meet ADA standards. Fares are charged on a per-mile or per-minute basis on top of a base charge for each trip.

- Volunteer Driver Programs: Local faith-based and nonprofit community-based organizations frequently have a network of volunteers who offer flexible transportation for shopping, medical appointments, recreation, and other activities. One-way, round-trip, and multi-stop rides are usually available; reservations are needed. These programs are typically provided free, on a donation basis, through membership dues, or for a minimal cost.

- Private Automobiles: It must be recognized that for many reasons - including but not limited to the availability or unavailability of viable options - many older adults rely on private automobiles (either self-driven or driven by a family member, a neighbor or friend, or a hired assistant) for many of their transportation needs.

In addition to the services described above, some regions or communities provide Mobility Management services to link individuals with available transportation resources and services. The National Center on Older adult Transportation defines two variations of mobility management:

- Individual level -- one-on-one or group education and counseling on transportation options and alternatives to driving, often referred to as "travel training"

- Systems level -- mobility management intended to facilitate coordination among transportation and human services providers and ensure the availability of a range of transportation options and modes to support older adults 
Several regions and communities around the country are in the process of trying to develop "one-call, one-click" mobility management systems wherein individual consumers will be able to access through a single telephone call or web-based portal a network of transportation providers that might include public transit, volunteer drivers, private pay providers, shuttles, travel training programs, resources for older driver safety, and more. These systems are also intended to match travelers' personal profiles with a service's eligibility requirements and accommodations (vehicle with wheelchair lift, door-to-door service, etc.).

\section{STAKEHOLDER CONVERSATIONS}

In order to bet insights on the current state of coordinated HSTP in Illinois, the project team sent conversation requests to the HSTP coordinators who are responsible for all 11 of Illinois' HSTP regions. Certain HSTP regions share a coordinator (one HSTP coordinator handles regions 1 and 3, another handles regions 4 and 7 , and a third handles regions 9, 10 and 11) so there are a total of nine HSTP coordinators statewide. The project team held conversations with eight of these HSTP coordinators, representing a very high response rate of $88.9 \%$ $(8 / 9)$.

The project team also sent conversation requests to the Executive Directors or other identified key or staff dealing with transportation at all 13 of Illinois' AAA regions. The requests invited the recipient to forward the request to another staff person within the agency if that individual would be a better resource for the requested conversation. The project team held conversations with a key staff person at five of the 13 AAAs, representing a reasonable response rate of $38.5 \%$ (5/13). Although this response rate is well above the typical 15-25\% range often predicted for general surveys, the project team believes that self-selection was involved in determining whether or not a specific AAA responded to the conversation request. Those AAAs who did respond to the conversation request had very specific perspectives and thoughts on coordinated transportation planning in Illinois that they freely shared; and the project team believes that the AAAs who did not respond to the conversation request may not have had as many transportation-related insights.

All of the identified key local, state and nation-wide stakeholders to whom the project team reached out agreed to have conversations. Several of the stakeholders to whom the project team reached out suggested additional stakeholders to whom the project team might also reach out. These conversations yielded a high degree of candor across the board. To a person, the stakeholders spoke very freely and, interestingly, many asked if the interviews were off-the-record (which they were assured they were) and whether their comments would be specifically attributed to them or their agencies (the project team indicated that while the names and affiliations of conversation-holders would be identified in the project report, no specific comments or quotes would be attributed to specific individuals.)

\section{KEY FINDINGS FROM STAKEHOLDER CONVERSATIONS}

Key themes that permeated the conversations with the HSTP regional coordinators included:

- The Coordination Process - Most HSTP coordinators (some of whom work part-time on HSTP, while others work full-time on it) feel good about the HSTP process and their roles in it. But all feel that the coordination process as it currently exists is definitely sub-optimal, should not be seen as "all things for all people all the time," and could be improved upon in different ways. Some stakeholders went as far to say that coordination is Illinois was "dead" while others felt that it had evolved to a second phase more of compliance than enhanced coordination. To a person, the HSTP coordinators feel that the Illinois HSTP coordination process has yielded significant benefits to the state's underserved population, particularly in rural areas, many of which did not have public transportation until the coordination process over the past decade brought public transportation to their areas. 
- Shared Transportation Services - Many HSTP coordinators indicated that the human service agencies in their regions (including but not limited to agencies serving older adults) are very amenable to shared services, wherein different types of riders with different travel needs and destinations are all accommodated in a shared vehicle. Some stakeholders indicated that this acceptance initially took awhile in areas where the shared service supplanted specific human service agency-supplied transportation services.

- Human Service Agency Coordination - The HSTP coordinators all feel that there was adequate outreach to and participation by human service agencies (including those serving older adults) in their regions. There is, however, an underlying feeling held by many of the HSTP coordinators that many of the human service agencies in their regions want in concept to coordinate, but that the agencies' actual involvement with coordination that would require compromise by their agency or their clients is much less widespread.

- Transportation Planners/Human Service Agencies - Most (although not all) HSTP coordinators and other key stakeholders feel that there is a fundamental mismatch in the goals and success definitions between most transportation planners and providers and human service agencies. Transportation planners and providers' goals and success metrics deal more with system-wide efficiency and performance; while human service agencies' goals and success metrics deal more with addressing individual client needs, even if doing so does not enhance system-wide efficiencies. Several HSTP coordinators and other key stakeholders feel that this mismatch limits realistic expectations of coordinated HSTP success.

- Public Satisfaction with Public Transportation - It seems clear from conversations with the HSTP coordinators and other stakeholders that clients in areas of Illinois with newer public transportation service are generally more satisfied than clients in areas where public transportation services grew from transportation services previously provided by human service agencies. This is likely due to "not as good as it used to be" type complaints leveled by clients of a transportation service who had been users of the prior service (regardless of the actual efficiency or fiscal sustainability of that service).

- Local Political Support and Understanding - The HSTP coordinators as a group feel that local political understanding about the complicated issues involved in coordinated HST planning is in very short supply. More importantly, they feel that this lack of real understanding often leads to a lack of local political support, which is seen as a major challenge.

- Transportation Service Demand Levels - The HSTP coordinators focus on trying to provide adequate transportation services to meet the current demand level within their regions, which is usually defined as a slight increase over the previous year's number of provided rides. They rely on the transportation providers, the human service agencies or others to provide data as to potential future service demand levels. However, a number of HSTP coordinators did specifically point out their observations of increasing demand levels among dialysis patients and veterans in their regions.

- Communications - Many HSTP coordinators mentioned communications as a challenge, although in different respects. Several mentioned the intermittent nature and perceived inadequacy of HSTP coordination guidance communication from the state level. Others mentioned the perceived difficulty that the public and potential users of transportation have accessing comprehensive and useable information about transportation services in their area. In most cases, the HSTP coordinators are left to hope that some combination of transportation providers or human service agencies provides transportation service information to potential users, and they have little real sense as to the effectiveness of this public communication. 
- Mobility Management - Several HSTP coordinators and other key stakeholders have some personal familiarity with mobility management efforts, and see it as an important missing component of Illinois" HSTP coordination. Those familiar with mobility management strongly feel that it should be implemented at a regional or local level.

- System Compliance and Oversight - A number of HSTP coordinators and other key stakeholders brought up concerns about the state's compliance of the overall coordinated system, and referenced concerns over instances of alleged funding and vehicle use abuses. IDOT's recently rolled-out Program Compliance Oversight Monitor (PCOM) program is seen as an improvement that will help bring compliance, but several HSTP coordinators mentioned local reluctance to incur the additional costs of implementing PCOM.

- Funding - Every single HSTP coordinator indicated the major challenge of trying to maintain current levels of coordinated HST service at current funding levels. Most are truly concerned about trying to maintain even current transportation service levels in the future - let alone providing potentially increased services needed to meet perceived heightened future demand due to demographic shifts - without a significant increase in transportation funding.

Key themes that permeated the conversations with key AAA staff persons who deal with transportation included:

- The Coordination Process - There was significant variance between AAAs as to their participation with regional HSTP coordination efforts. Some AAAs have been significantly involved over the past decade, while other AAAs were not even aware of ongoing regional HSTP planning efforts in their area. Most AAA staff persons did feel, however, that transportation services had improved in their regions since the onset of Illinois' HSTP process, particularly in those rural areas which did not have public transportation until recently.

- $\quad$ AAA Involvement in HSTP Coordination - The fact that the defined HSTP regions vary significantly from most of the AAA planning and service areas -- with portions of a single AAA included within up to four separate HSTP regions -- makes active AAA participation in regular planning or committee meetings a challenge which is not always seen as worthwhile when making staff time allocation decisions. Most AAAs leave actual coordinated HSTP involvement to their human service or transportation service grantees within a local area.

- Shared Transportation Services - Several key AAA staff persons indicated that they feel that certain (nonolder adult-serving) human service agencies have not participated well in coordination efforts due to their agencies' or clients' fears of relinquishing control or funding over existing transportation services.

- AAA-funded Transportation Services - Despite some participation with regional HSTP coordination efforts, most AAAs and their grantees still provide their own agency-specific transportation services above and beyond the officially coordinated regional transportation services. While several AAA staff persons indicated that this was due to program or data requirements, or pricing or funding differences, it still points to the ongoing challenges to providing truly coordinated transportation. In addition to AAAfunded services, AAA staff was often aware of other local community-based transportation services such as volunteer driver programs, about which most HSTP coordinators were unaware. 
- Transportation Planners/Human Service Agencies - Most key AAA staff persons agree with most HSTP coordinators and other key stakeholders that there is a fundamental mismatch in the goals and success definitions between most transportation planners and providers (efficiency-centered) and human service (individual client-centered) agencies, and that this mismatch limits realistic expectations of coordinated HSTP success.

- Transportation Service Demand Levels - Unlike most HSTP coordinators, the AAA key staff persons were keenly aware of increasing future demand for transportation services, and they are deeply concerned about not only maximizing the impact of current transportation services benefitting their clients, but also how they will be able to scale up to meet future demand.

- Communications - Most AAA staff persons agree with those HSTP coordinators who mentioned public knowledge of available transportation services as a challenge. While the AAAs do provide some information to potential transportation service users, they -- like the HSTP coordinators -- are generally left to hope that the transportation providers provide transportation service information to the public and potential users, and they have little real sense as to the effectiveness of this communication.

- Mobility Management - Those key AAA staff persons with familiarity with mobility management agree with the HSTP coordinators who see it as an important missing component of Illinois" HSTP coordination, and agree that it should be implemented at a regional or local level. Several AAA staff persons pointed out that mobility management is already provided to some extent by other older adult-serving programs such as the Aging and Disability Resource Centers (ADRCs) that are information programs provided by certain AAAs or counties.

- $\quad$ Funding - Just as with the conversations with HSTP coordinators, every AAA staff person indicated the major challenge of trying to maintain current levels of transportation (and other) services at current funding levels. Most are truly concerned about trying to maintain even current transportation service levels in the future - let alone providing potentially increased services needed to meet the known heightened future demand due to demographic shifts - without a significant increase in transportation funding.

\section{KEY CURRENT ILLINOIS HSTP PRACTICE FINDINGS}

Taking into consideration both the HSTP coordinators and key AAA staff input, a number of general and specific findings on the state of Illinois HSTP as currently practiced come to the forefront:

- $\quad$ State HSTP Coordination Process - The decade-long coordination process has yielded real and enduring benefits, particularly in rural and lower density areas of the state which did not previously have public transportation service. That said, true leadership from the state appears to have waned, and the process evidences a widespread tired and cynical nature.

- Regional HSTP Coordination Efforts - A number of regional coordination efforts are still ongoing and enjoy widespread human service agency participation, while others have considerably become more a matter of service maintenance and compliance rather than creative problem-solving.

- AAA or Aging Network Participation - Most HSTP regions enjoy at least some AAA or localized aging network participation, although in a number of regions the AAA participation has diminished over time do to the feeling of minimal input compared to extensive staff time commitment due to the distance to the multiple meetings, often in multiple HSTP regions. 
- Future Service Demand - Neither the HSTP coordinators nor the AAAs have a real handle on the potential demand level for transportation services.

- Information Dissemination/Public Awareness - Most HSTP coordinators and AAA staff feel that the level of public information about available transportation services is inadequate in their regions.

- Mobility Management - Those HSTP coordinators and AAA staff familiar with mobility management strongly suggest that it should be incorporated into HSTP coordination efforts going forward, and see it as potentially greatly improving the public's information about available transportation services.

- Multi-Modal HST Practices - Coordinated HSTP in Illinois only goes so far, and there are numerous examples of older adult-serving and other human service agencies simultaneously participating in coordination efforts while still maintaining their own agency-serving transportation services. In addition, no regional HSTP effort appears to go granular enough to include volunteer driver and similar communitybased programs.

- Political Sponsorship - All stakeholders feel that state and local level political sponsorship is important to effective regional coordinated HSTP, and that in a number of areas, political understanding and sponsorship is viewed as inadequate.

- Funding - Nearly all stakeholders feel that imperiled funding impedes current coordination efforts, and that lacking greater and more reliable funding in the future, the availability to serve higher demand levels will be difficult to impossible.

- Northeast Illinois "Region 0" - While transportation providers RTA and Pace are doing a good and sincere job serving as transportation planners for the metropolitan Chicago region in northeast Illinois, the shortage of AAA involvement, the absence of CMAP's multi-sectoral perspective and leadership, and pervasive regional political and turf challenges limits overall regional HSTP coordination.

\section{NOTABLE HSTP PRACTICES IN ILLINOIS}

The project team asked stakeholders in all conversations to identify notable coordinated HSTP practices from their own regions or with which they were familiar. While many stakeholders did not identify any notable programs in their regions, several notable programs were identified, and in some cases by numerous stakeholders. The identified programs are briefly highlighted below, along with other notable HSTP programs identified by the project team, with key program components indicated. No attempt was made to provide a detailed focus on major operational aspects such as vehicle types, driver training, funding, or other program components.

While the examples of notable HSTP is not an exhaustive list, and no single program from one location is likely to be exactly replicable in another location, these short program sketches serve to point out promising program elements that may well offer enhancement potential to programs in other areas.

\section{Rides Mass Transit District (RMTD or “Rides”)}

Since 1977, Rides has been providing convenient, affordable and accessible public transportation throughout southeastern Illinois. Rides was nationally recognized in 2000 as the Transit System of the Year by the Community Transportation Association of America (CTAA) and in 2005 received the United We Ride Award. 
Service is available to anyone needing transportation. Rides provides door-to-door and fixed route service. Rides' fully accessible fleet consists of lift-equipped and ramped vehicles. In addition to its local residential and in-district scheduled route services, Rides schedules out-of-district trips to enable passenger access to major medical facilities, shopping centers, employment sites and educational centers throughout Illinois, and the neighboring states of Indiana, Kentucky, and Missouri.

Agencies negotiate contracts with RMTD to provide transportation to their customers. Rides leases passenger space (but not exclusive use) of its fleet on all routes to provide more efficient service to a broad range of riders. Users know that when they ride a Rides vehicle, service is open to a wide range of individuals, and the rules of the service are made by Rides to accommodate the range of participating agencies and user needs.

Rides' philosophy is that HSTP coordination is not rocket science, and that the only way to build success as a coordinated HST service provider is to combine funding streams. According to Rides, true coordinated HSTP requires persistence, performance and commitment, as opposed to simply attending coordination meetings.

\section{Township Ridership Initiative Pilot (TRIP)}

TRIP is a state-funded program operated by Schaumburg Township in metropolitan Cook County near Chicago that provides inter-township transportation services for older adults and people with disabilities. Pace is the service provider, and provides accessible vans or small buses.

Users of TRIP can reside in one of four townships (Schaumburg, Elk Grove, Palatine, and Hanover Townships), and the service area extends to seven townships plus three regional hospitals beyond the seven counties.

According to key stakeholders, the development of TRIP to provide coordinated HST is a case study that proves that strong local political leadership and sponsorship can overcome jurisdictional, institutional, and programmatic barriers. TRIP was initially developed by the townships in response to local transportation needs and travel patterns, gained the sponsorship of local elected officials, and has now become part of the region's official HSTP.

\section{SHOW BUS}

SHOW BUS has been providing public transportation to residents of rural central Illinois since 1979. Its services are available to all residents of rural DeWitt, Ford, Iroquois, Kankakee, Livingston, Macon, and McLean counties. SHOW BUS has two types of scheduled routes: limited stop (fixed-route) service and door-to-door (deviated route) service. For limited stop service, the schedule has specific high demand pickup/drop-off locations indicated within or between individual counties. For door-to-door service, the schedule indicates a general geographic area.

When SHOW BUS' scheduled routes don't fit individual transportation needs, it provides Special Routes that are tailored to meet individual needs. Because of limited resources, SHOW BUS places a limit on how many Special Service Routes it can provide, but they attempt to provide individual transportation assistance as best as possible.

SHOW BUS assists with non-emergency medical transportation including hospital discharges, emergency room discharges or medical appointments. Medicaid recipients ride for free with prior approval.

SHOW BUS works with numerous human service agencies by offering service contracts that can provide all of the transportation for an agency, provide supplemental transportation for an agency, or a way to provide 
discounted transportation for an agency's clients on an as-needed basis. SHOW BUS' voucher program reimburses human service agencies that assist individuals with especially difficult mobility obstacles, such as assisting with payment for travel assistants.

\section{Ride In Kane}

Ride In Kane is a transportation program through a partnership of Pace Suburban Bus and Kane County government entities to provide transportation for older adult, disabled, and low-income individuals in Kane County. Service is provided within Kane County only, and is provided with taxis, PACE lift-equipped buses, or mini-vans for demand response.

All riders must be registered through a participating human service agency, and approved rides must be scheduled through the agency. Ride service is curb-to-curb including residential or business locations. Drivers do not assist riders in and out of buildings but attempt to assist riders into and out of vehicles. When a rider's needs are beyond the responsibility of the driver, a travel assistant is required and rides at no charge.

\section{Ride DuPage}

Similar to Ride In Kane, Ride DuPage is a transportation service that operates seven days per week, 24-hours a day. Organizations such as municipalities, townships, social service organizations, and employers can participate by subsidizing transportation for their clients or constituents.

Sponsoring agencies determine the eligibility for their riders. For example, a municipality may wish to establish eligibility based on age or disability, while a social service organizations may establish eligibility based on income.

Many riders can book service directly with Ride DuPage, although older adult riders sponsored by DuPage County Older adult Services are required to book their rides through DuPage County Older adult Services.

\section{Fulton County Volunteer Drivers Program}

A number of small community-based agencies in Fulton County in west central Illinois all offer some type of successful volunteer driver program. They got together to provide a coordinated ("Super Saturday") training program, which was established by a rural transportation funding grantee, and received the support of both the HSTP committee and the RTAC.

\section{NOTABLE HSTP PRACTICES AROUND THE COUNTRY}

For benchmarking purposes, the project team identified and investigated several notable examples of coordinated transportation programs in a variety of settings around the United States. Available documents were reviewed, and in several instances, conversations were held with key program stakeholders in order to gain further insights on their programmatic experiences. While all programs are location-specific and reflect unique local conditions and stakeholders, and no single program can be wholly duplicated in another location, there may be generalized approaches and findings from one program that may be applicable to others. Brief highlights of promising coordinated HSTP practices from elsewhere around the country are featured below, along with key points for potential replication. 


\section{Coordinated Transportation Networks}

\section{Maricopa County, Arizona -- Maricopa Association of Governments (MAG) Municipal Aging Services Project}

MAG is the Phoenix region's Council of Governments (COG) and its MPO and regional HSTP coordinator, and plays a broader role as the leader of a regional age-friendly network that promotes community-specific housing and transportation plans. MAG coordinates closely with the regional transportation service provider and the state DOT. A key to MAG's success over a very large and diverse region is "balanced power" in which the regions mayors work well together at the regional council level.

MAG coordinates much of the region's federal transportation funding, and this allows it to force area human service agencies to coordinate and share vehicles as appropriate and efficient. MAG coordinates a full range of coordinated HST services, including buses, vans, and private automobiles providing fixed route, demand response, and deviated fixed route services. Community-based not-for-profit organizations that run small scale transportation services such as volunteer driver programs are actively involved in MAG. With nine local transportation agencies, however, paratransit vans crossing jurisdictional boundaries is sometimes still an issue. MAG runs the region's Transportation Ambassador Program (TAP) whose goal is to create a network of people informed about the most current HST information and resources in to better service the community. TAP has 400 organizational and individual members, and meets quarterly to discuss ongoing regional coordinated HST issues.

MAG also coordinates the regions three working and one planned mobility management programs that are run by different area not-for-profit agencies. These mobility management programs foster HSTP coordination and provide consumer information, but have not yet achieved true " 1 call/1 click" service as it is seen as very costly and challenging.

\section{San Diego, California -- On the Go Transportation Solutions for Older Adults}

On the Go is run by the Jewish Family Service of San Diego (JFSSD), which has been a leading transportation planner and provider for many years. On the Go provides a range of transportation services from donationbased volunteer driver-provided rides to fee-based medical, educational, shopping and recreational shuttles, and a premium fee-based personalized service.

While SANDAG is the region's MPO and leads coordinated planning efforts, SANDAG, the area AAA, the county and the city of San Diego come to JFSSD to help solve transportation challenges, including fixing failed small-scale transportation programs begun by various community-based organizations.

Believing that "nothing will kill a volunteer driving program without public relations and knowledge about it" On the Go set up and runs the San Diego Volunteer Driving Coalition that brings together numerous community-based stakeholders regularly, and discussed innovative transportation ideas beyond volunteer driving. On the Go sees the key to successful coordinated HSTP as "getting non-aligned parties to all see reasons to support programs" and "sit down up front to buy into the program in order for it to work" and that you "need a plan of attack" to develop popular support to help ensure program sustainability.

\section{Florida -- Commission for the Transportation Disadvantaged (CTD)}

Florida's well-established, multi-level coordination system is often cited as a successful example of coordinated HST. Recognized by the Departments of Transportation and Health and Human Services as a "best practice" 
model, it has won awards from the Federal Transit Administration (FTA) and the CTAA. Florida's system is intended to balance local flexibility with comprehensive state planning, policy and oversight, and the law clearly defines the roles of state, regional and local entities. At the state level, the CTD was created by the Legislature as an independent state agency in 1989 and by law includes at least five voting members with business experience, two with disabilities, and one over age 65, plus ex officio advisors from the state agencies for Children and Families, Elder Affairs, Health Care Administration, Persons with Disabilities, Transportation, Veterans Affairs and Workforce Innovation.

The CTD is responsible for statewide coordination of transportation services for transportation disadvantaged people, defined as those who, "because of physical or mental disability, income status, or age are unable to transport themselves or to purchase transportation" or children who are "handicapped, high-risk or at-risk. The system also includes local designated planning agencies; local coordinating boards that act as advisory bodies in their service areas; and community transportation coordinators (CTCs) that provide, contract for or broker transportation services in each county. State agencies that fund transportation services either purchase trips from a CTC or are billed directly by service operators. The CTD now is adding mobility managers in each county within the CTCs.

\section{Knoxville/Knox County, TN -- Volunteer Assisted Transportation (VAT)}

The VAT program utilizes trained volunteers to drive an agency-owned fleet of hybrid automobiles and wheelchair minivans. Originally developed in 2008-2009, the program has utilized mostly federal funds to pay for vehicles. The VAT program is funded under an agreement with the Federal Transit Administration and the Tennessee Department of Transportation and is administered by the Knoxville Regional Transportation Planning Organization, with partners including the National Center on Older adult Transportation, the local AAA, and other local health care and business community partners. Since VAT's launch in March 2009, 93 individual volunteers have traveled over 200,000 miles, providing 17,500+ trips to more than 500 older adults and people with disabilities.

\section{Mobility Management}

\section{Dallas, Texas -- MY RIDE Program}

MY RIDE is a program of the Community Transportation Network, a coalition of more than 150 individual partners representing 90+ organizations and businesses that works to improve access to community transportation for older adults and people with disabilities in Dallas County. The Community Transportation Network, set up in 2009 by the Community Council of Greater Dallas and the Dallas AAA, with support from the North Central Texas Council of Governments, meets as a coalition every other month, with work teams meeting monthly.

MY RIDE is envisioned as a one-stop mobility management resource. MY RIDE's annually-updated Get a Ride Guide has transportation options for residents of Dallas County, especially for people with disabilities and older adults. The Guide is 36 pages long, and can be downloaded from the MY RIDE Dallas website in English and Spanish.

There is close coordination between the Community Council's 2-1-1 Call Center/Aging Information Office and the MY RIDE program. A referral process is in place: 2-1-1 call specialists offer the MY RIDE telephone number 
to all adults age 60 and over and callers who self-identify as having a disability. In addition, 2-1-1 data is used to monthly evaluate consistency in the quality of service/opportunities, and to refine the resource database and update working knowledge of 2-1-1 staff.

\section{Tompkins County, NY -- Consolidated Area Transit (TCAT)}

Tompkins Consolidated Area Transit, Inc. (TCAT), Ithaca, NY, has been recognized as one of the best transit system of its size in North America. Over the past several years, TCAT has taken great strides in ridership growth, safety practices, workforce training, community outreach and environmental sustainability.

TCAT's service area covers a semi-rural population of 102,000 in Tompkins County. TCAT's 33 bus routes transport both out-of-county and in-county residents to and from Cornell University, Ithaca College, Tompkins Cortland Community College as well as retail, entertainment, commercial, residential and professional centers. TCAT operates 22 hours a day, seven days a week and 360 days a year.

Tompkins County has improved transportation equity and sustainability aspects for all residents through its Way2Go mobility management program that is guided jointly by the county Department of Social Services and the Ithaca Tompkins County Transportation Council (the regional MPO) and was developed and is implemented by Cornell Cooperative Extension Tompkins County. Way2Go coordinates an integrated series of bus services, paratransit services, volunteer driver, car sharing, ridesharing incentives, and related programs.

Way2Go offers a free "Retiring from Driving: It Isn't the End!" workshop that focuses on driving alternatives and strategies to transition from driving. Presenters provide information on several alternatives to driving, such as:

- Transit

- Paratransit

- Volunteer driver programs

- Taxi and car services

- Zimride Tompkins, a localized carpool tool to find rides or riders to share driving and costs of trips

- Ithaca Carshare, which offers members hourly access to cars across Ithaca, and runs the Easy Access Plan for income-qualified members

- Gadabout, which offers inexpensive rides by reservation for people 60 and over, or people with disabilities

\section{Rural Washington and Idaho -- COAST}

The Council on Aging \& Human Services (CoA\&HS) is a nonprofit social service agency in eastern Washington near the Washington-Idaho border, where it covers a 22,000 square mile rural service area. COAST is the transportation program of CoA\&HS, but its services are not limited to older adults and individuals with special needs. COAST provides specialized and public transportation services to residents of eight counties, three in Washington and five in Idaho. In rural areas, COAST provides public and specialized transportation services; in small urban areas it offers services that are not offered by public transit providers operating there.

COAST operates vehicles, serves as a broker for transportation services, operated a vehicle insurance pool, acquires and loans vehicles, operates vanpools, supports carpools, provides training services, maintains vehicles, operates an eight-county Information and Referral service, and dispatches rides throughout the region. COAST operates with both paid and volunteer drivers; some of its trips cover very large distances: for example, one-way trips between Clarkston and Spokane cover a distance of 120 miles. 
Two features of COAST's approach to mobility management are its mission toward mobility and its customer orientation. Since 1984, COAST has been guided by the vision that mobility should not depend on individual circumstances of income, age, disability, or other characteristics. COAST has been actively involved in legislative processes to change eligibility criteria and funding sources of transportation programs, and helped persuade the State of Washington to implement a unique funding program for riders with special needs. It also played a key role in the formation in 1998 of Washington's state level Agency Council on Coordinated Transportation whose mission is to coordinate affordable and accessible transportation choices for people with special needs, in collaboration with state and local agencies and organizations.

COAST's mobility management services extend to the general public, older adults, school children, commuters, persons with physical, mental, and developmental disabilities, low income persons, Medicaid recipients, veterans, and many others. COAST has agreements with a wide range of agencies and service providers, including public transit operators, private for profit providers, area agencies on aging, schools, sheltered workshops, hospitals, Head Start programs, and many others. COAST brokers or provides shared vehicle services at night or during weekends when such services are not offered by other public transportation providers or to destinations not otherwise served.

\section{Key Findings from Notable Practices around the Country}

The project team has distilled a number of key findings from the notable coordinated HSTP practices around the country that it evaluated. The project team believes that most of these key findings are applicable and could be incorporated into efforts to further enhance coordinated HSTP around Illinois going forward.

1. Political champions - at the state, regional and community levels - are critical. Political leadership, especially amongst key elected officials, is absolutely necessary to influence funding and operational decisions to provide coordinated HSTP. Political championship can be nurtured by educating elected officials on the needs and benefits of coordinated HSTP in their municipalities and regions.

2. Sustained, all-inclusive regional leadership, elected officials, transportation planners and providers, human service agencies, community-based organizations, and others is critical. If leadership does not exist, it is unreasonable to expect for citizens to promote and sustain coordinated HSTP in their areas.

3. Because of their unique perspectives and positions to balance transportation, land use, human services and other types of planning, MPOs need to function as critical champions of HSTP. The most effective MPOs serve as committed champions of coordinated transportation planning by leveraging their trustbased working relationships across multiple silos, including with community-based and not-for-profit organizations. Regions that do not enjoy strong MPOs that function as coordinated HSTP champions demonstrate less broad-based coordinated involvement efforts.

4. Regular convening of all coordinated transportation players - including transportation agencies \& providers, human service agencies, funders, politicians and other stakeholders -- is invaluable. Convening stakeholders merely to update the existing HSTP at required points is a much valuable substitute and isn't likely to provide the types of community-building, problem-solving and knowledge-sharing benefits of regular and sincere stakeholder meetings.

5. Mobility management is most effective when it encompasses all types of transportation (public, private, 
multi-modal), provides "1-call or 1-click" service, and includes travel training and other client services. Although costly and difficult to establish and maintain, mobility management holds great promise to better inform potential users of transportation services of their options in real time. The more comprehensive the mobility management program, the more likely it will be to meet widespread client needs.

6. Mobility management and "1-call or 1-click" type call centers work best at the regional level, as too geographically limited services will generally not align with travel needs, and too broad services will be overly complicated to keep current. Also, as building a comprehensive transportation service database, training staff, and developing procedures require lots of time, it is important to be patient when developing a mobility management program. 


\section{SECTION 4: CONCLUSIONS \& RECOMMENDATIONS}

Building upon all three sections of this report, the project team has developed the following set of overall conclusions and policy recommendations that suggest ways to facilitate aging-in-community and enhance coordinated HSTP at the federal, state and regional levels. The United States overall, and Illinois in particular, has made significant strides in supporting coordinated HSTP and aging-supportive communities, but much more work needs to be done.

\section{FACILITATING AGING-IN-COMMUNITY}

1. Plan for a variety of housing typologies - With the oncoming wave of Baby Boomers, an unprecedented number of households will be looking to downsize and move into smaller homes. Data shows that while many older Illinois residents continue to live in single family homes at age 65, this figure drops off significantly by age 75. Many communities currently do not have the variety or availability of smaller housing stock to accommodate this shift in preferences and needs. Recommendations on the local level that can help communities prepare for this shift in housing needs include modifying zoning codes to allow for more multi-family or smaller lot construction, and allowing for accessory dwelling unit "granny flat" housing.

2. Better accommodate home and community accessibility - As the population ages, a growing number of older adults will face challenges associated with disability and limited physical mobility which will require additional housing modifications and transportation accommodations. A large part of one's ability to remain in one's home and community hinges on the availability of these accommodations. Supporting the conversion of homes and construction of accessible units, in combination with other community-scale modifications, will make it easier for older adults with a disability to stay in their homes and communities.

3. Recognize rural needs - In absolute numbers, the greatest growth in the older adult population will likely occur in and around the Chicago metropolitan area. However, most of the areas of Illinois that have the highest concentrations of older adults relative to their total populations are in rural parts of the state. The aging of rural counties comes with its own set of unique challenges to which state and local planners and elected public officials must be sensitive. Older adults in rural areas are more geographically isolated than their urban counterparts and further from healthcare and other services. As they continue to age, they will retire, which has implications for the local workforce and tax base. Furthermore, rural counties that are losing younger residents for economic reasons may have additional challenges when it comes to the availability of caregivers for older residents. Rural areas should proactively plan for this increasing concentration of older adults and lay the groundwork for added transportation, healthcare, and social services. Planning for increased need and capacity goes hand-in-hand with strategies to educate older adults on the availability and use of these services.

\section{ENHANCING HSTP COORDINATION IN ILLINOIS}

1. Provide more commitment to and leadership on coordinated HSTP at the state, regional and local levels - HSTP coordination is not a goal that can be achieved and the process ended, it needs to be an ongoing commitment and effort to reach current goals and demand levels while anticipating future ones. Key HSTP stakeholders should meet regionally on an ongoing (rather than on just a compliance or plan update) basis.

\section{Focus on comprehensive multi-sector HSTP coordination rather than just on compliance with current}


service levels - The focus of the ongoing HSTP coordination efforts throughout the state should be on filling the remaining service gaps, eliminating the still-existing service overlaps, and reaching greater operational efficiencies, rather than merely on acceptance and compliance with where we are currently at.

3. Work to replace agency-specific transportation services wherever possible with more efficient shared services - Maintaining the current system of numerous officially 'coordinated' augmented by numerous additional agency-specific services indicates that true coordination has not been achieved.

4. Aspire to true comprehensive multi-modal regional HSTPs - Some of the agency-specific augmented transportation services include small scale or community-based services such as volunteer driver or taxi voucher programs that ideally should be incorporated into the regional HSTPs.

\section{Achieve true regional mobility management and "1-click/1-call" services throughout state -} Coordinated HSTP without adequate and easy public and potential client knowledge and access would constitute a hollow and partial success. We need to develop true "1-click/1-call" services that allow users to schedule transportation services, or, at a minimum provide "warm referrals" the connect users to a person who can schedule them.

6. Face the realities of increased future demand - while not under appreciating the critical importance of providing adequate HSTP at today's funding and need levels, too little attention appears to be on projecting and anticipating obvious growth in critical human service populations including older adults, dialysis patients, and veterans.

\section{ENHANCING HSTP COORDINATION AT THE FEDERAL LEVEL}

1. Provide truly committed leadership and funding at federal level - Nearly a half century of calls for better coordination transportation planning - including HSTP - at the federal level have proven woefully inadequate. Bi-partisan political leadership and increased and stabilized funding levels are absolutely critical.

2. Demonstrate that it won't take a real crisis to address future transportation coordination challenges A component of true political courage is to not require high-profile tragedies to force our national leadership to address the transportation needs of the most transportation-disadvantaged components of our country.

\section{Focus on true inter-departmental coordination instead of intermittent appearances of participation} - The complexities of the existing federal transportation funding program requires true across-the-board coordination commitment, which is certainly not currently the case, as a number of departments are still doing their transportation planning in their traditional silos.

4. Get serious about the business of eliminating federal barriers to true transportation coordinationDecades of calls for and alleged commitments to eliminating federal programmatic and funding barriers to coordination have yielded very little progress. Strong leadership, public mandates and commitments, and implementation deadlines and penalties are absolutely necessary, regardless of the fiefdoms that would be challenged.

5. Consider a complete game-changing consolidation of all federal transportation programs to increase efficiency, and give states, regions and communities more flexibility to achieve planned goals - There should be serious consideration of a complete reconstruction of how the federal government plans, funds and operates transportation. Models that could be considered for replication or expansion include: 
o The Community Development Block Grant (CDBG) Program -- Authorized under Title I of the Housing and Community Development Act of 1974, as amended, the stated goals of the CDBG Program are "To develop viable urban communities, by providing decent housing and a suitable living environment and expanding economic opportunities, principally for persons of low and moderate income." The CDBG program was intended to enable communities to define and address their community needs at the local level under the governance of local elected officials, and flexibly utilize available community development funds to address these locally-defined needs, rather than having to follow the detailed programmatic rules and guidelines of various federal programs.

Prior to the creation of the CDBG Program in 1974, there were numerous federal programs which addressed community development issues, and CDBG grew out of the consolidation of eight categorical programs under which communities competed nationally for funds. The consolidated programs included:

- Open Space

- Urban Renewal

- Neighborhood Development Program grants

- Historic Preservation grants

- Model Cities supplemental grants

- Public Facilities loans

- Neighborhood Facilities grants

- Water and Sewer grants

While there is ongoing concern over declining CDBG funding levels and outdated CDBG funding formulas, there is also widespread appreciation that CDBG has been successful in terms of its flexibility, and its support for balanced regional planning and community-based strategies. A similar approach might yield similar success with transportation programs.

o Transportation Investments Generating Economic Recovery (TIGER) Grants -- TIGER was first launched as part of the 2009 economic stimulus bill. The concept was to help communities move projects that do not fit neatly into the highway or transit funding programs. The emphasis is on competition, innovation and fiscal impact.

The response has been outstanding, in number and in the breadth and range of projects. In the first year, 1,400 communities applied for a total $\$ 60$ billion, and 51 ended up splitting the $\$ 1.5$ billion available. It has been estimated that about 20 percent of each round's submissions were strong, well-conceived projects with local matching funds and were worthy of a grant, but only about five percent could be funded.

Notable TIGER-funded projects have been very diverse, including: a systematic effort to reduce bottlenecks that hamper freight and commuters alike in Chicago, the nation's busiest rail hub; a jobcreating and private investment-spurring transit service extension in post-Katrina New Orleans; a multimodal station that became the busy center of what had been a moribund small city downtown; the rebuilding of crumbling bridges that made new connections and safe crossings for bicyclists and pedestrians; and economic development-enhancing access improvements to numerous ports and freight terminals. 
All of these funded examples addressed multiple problems at once, and almost none would have been funded within existing transportation funding silos. The key lesson learned is that competition spurs innovation that formula funding seldom will. As a result, federal dollars are made to go farther, more non-federal funds are brought in from both public and private sources, and funding is targeted to accomplish multiple goals.

Competitive TIGER grants have opened a door for local elected officials, civic groups, institutions, and employers to engage for the economic benefit of their community, connecting federal transportation funding to communities in creative problem-solving ways. Future transportation funding authorizations could build on this success, and shift more emphasis to funding projects that local states, regions, and communities have determined are most beneficial and necessary. 
Appendix A: Alternative G Summary for Fastest and Slowest Changing Counties in Illinois, 2010 - 2030

\begin{tabular}{|c|c|c|c|c|c|c|c|}
\hline \multicolumn{4}{|c|}{ Change for $65+$ Population } & \multicolumn{4}{|c|}{ Change for Total Population } \\
\hline & Most & & Least & & Most & & $\begin{array}{l}\text { Least } \\
\text { (Loss) }\end{array}$ \\
\hline Cook & 371,467 & Pope & 63 & Will & 334,787 & Rock Island & $-2,502$ \\
\hline DuPage & 110,192 & Stark & 471 & Cook & 282,861 & Hancock & $-1,098$ \\
\hline Will & 97,191 & Calhoun & 476 & Kane & 160,206 & Mason & -848 \\
\hline Lake & 73,382 & Gallatin & 492 & Kendall & 117,965 & Gallatin & -421 \\
\hline Kane & 68,944 & Scott & 514 & McHenry & 69,545 & Pulaski & -279 \\
\hline McHenry & 47,627 & Hardin & 527 & DuPage & 57,871 & Saline & -257 \\
\hline Winnebago & 30,395 & Brown & 538 & Lake & 50,374 & Greene & -231 \\
\hline Madison & 26,012 & Hamilton & 655 & Winnebago & 40,218 & Christian & -162 \\
\hline St. Clair & 25,474 & Mason & 674 & McLean & 31,541 & Scott & -161 \\
\hline Sangamon & 24,009 & Pulaski & 681 & Madison & 30,319 & Edgar & -128 \\
\hline \multicolumn{4}{|c|}{ Percent Change for 65+ Population } & \multicolumn{4}{|c|}{ Percent Change for Total Population } \\
\hline & Most & & Least & & Most & & $\begin{array}{r}\text { Least } \\
\text { (Loss) }\end{array}$ \\
\hline Kendall & $202.8 \%$ & Pope & $6.5 \%$ & Kendall & $102.8 \%$ & Gallatin & $-7.5 \%$ \\
\hline Will & $154.7 \%$ & Warren & $23.8 \%$ & Will & $49.4 \%$ & Mason & $-5.8 \%$ \\
\hline McHenry & $152.1 \%$ & Mason & $24.0 \%$ & Grundy & $40.0 \%$ & Hancock & $-5.7 \%$ \\
\hline Kane & $138.7 \%$ & Ford & $30.0 \%$ & Boone & $31.9 \%$ & Pulaski & $-4.5 \%$ \\
\hline Boone & $119.5 \%$ & Pike & $31.9 \%$ & Kane & $31.1 \%$ & Scott & $-3.0 \%$ \\
\hline Grundy & $119.4 \%$ & Wayne & $33.8 \%$ & Monroe & $31.1 \%$ & Rock Island & $-1.7 \%$ \\
\hline Monroe & $117.8 \%$ & Fulton & $36.0 \%$ & DeKalb & $25.3 \%$ & Greene & $-1.7 \%$ \\
\hline McLean & $106.5 \%$ & Christian & $36.6 \%$ & McHenry & $22.5 \%$ & Saline & $-1.0 \%$ \\
\hline DuPage & $103.6 \%$ & Hamilton & $39.2 \%$ & Jersey & $22.5 \%$ & Edgar & $-0.7 \%$ \\
\hline Lake & $100.4 \%$ & McDonough & $39.3 \%$ & Williamson & $19.9 \%$ & Clark & $-0.6 \%$ \\
\hline
\end{tabular}


Appendix B: Summary of Alternative G Projection by HSTP Regions

\begin{tabular}{|c|c|c|c|c|c|c|}
\hline \multicolumn{4}{|c|}{ Total Population 65+ } & \multicolumn{3}{|c|}{ 2010-2030 Change } \\
\hline HSTP Region & 2000 & 2010 & 2020 & 2030 & Total & Percent \\
\hline 0 & 872,087 & 943,644 & $1,285,527$ & $1,712,447$ & 768,803 & $81.5 \%$ \\
\hline 1 & 55,243 & 64,131 & 88,025 & 113,057 & 48,926 & $76.3 \%$ \\
\hline 2 & 43,423 & 45,753 & 57,789 & 68,639 & 22,886 & $50.0 \%$ \\
\hline 3 & 55,749 & 64,104 & 89,926 & 123,702 & 59,598 & $93.0 \%$ \\
\hline 4 & 30,454 & 30,118 & 36,589 & 42,542 & 12,424 & $41.3 \%$ \\
\hline 5 & 70,860 & 72,940 & 94,572 & 114,537 & 41,597 & $57.0 \%$ \\
\hline 6 & 42,772 & 46,979 & 64,978 & 85,616 & 38,637 & $82.2 \%$ \\
\hline 7 & 49,575 & 52,044 & 69,306 & 87,341 & 35,297 & $67.8 \%$ \\
\hline 8 & 78,894 & 82,679 & 108,256 & 134,305 & 51,626 & $62.4 \%$ \\
\hline 9 & 75,631 & 77,447 & 100,547 & 129,579 & 52,132 & $67.3 \%$ \\
\hline 10 & 38,116 & 37,382 & 46,257 & 57,370 & 19,988 & $53.5 \%$ \\
\hline 11 & 89,746 & 91,992 & 123,282 & 159,869 & 67,877 & $73.8 \%$ \\
\hline Total & $1,502,550$ & $1,609,213$ & $2,165,055$ & $2,829,004$ & $1,219,791$ & $75.8 \%$ \\
\hline
\end{tabular}

\begin{tabular}{|c|c|c|c|c|c|c|}
\hline \multicolumn{3}{|c|}{ Total Population } & & \multicolumn{3}{|c|}{ 2010-2030 Change } \\
\hline HSTP Region & 2000 & 2010 & 2020 & 2030 & Total & Percent \\
\hline 0 & $8,106,464$ & $8,316,650$ & $8,803,924$ & $9,272,295$ & 955,645 & $11.5 \%$ \\
\hline 1 & 408,841 & 435,207 & 468,920 & 498,537 & 63,330 & $14.6 \%$ \\
\hline 2 & 278,487 & 272,964 & 276,967 & 276,699 & 3,735 & $1.4 \%$ \\
\hline 3 & 421,934 & 514,395 & 623,363 & 710,860 & 196,465 & $38.2 \%$ \\
\hline 4 & 180,059 & 174,768 & 180,991 & 182,830 & 8,062 & $4.6 \%$ \\
\hline 5 & 461,239 & 469,174 & 492,888 & 506,540 & 37,366 & $8.0 \%$ \\
\hline 6 & 340,107 & 365,770 & 398,019 & 420,840 & 55,070 & $15.1 \%$ \\
\hline 7 & 340,458 & 344,485 & 363,034 & 375,579 & 31,094 & $9.0 \%$ \\
\hline 8 & 570,716 & 583,785 & 613,084 & 633,472 & 49,687 & $8.5 \%$ \\
\hline 9 & 497,635 & 506,218 & 535,711 & 555,409 & 49,191 & $9.7 \%$ \\
\hline 10 & 214,789 & 208,480 & 211,948 & 215,521 & 7,041 & $3.4 \%$ \\
\hline 11 & 620,117 & 638,736 & 668,412 & 678,733 & 39,997 & $6.3 \%$ \\
\hline Total & $12,440,846$ & $12,830,632$ & $13,637,262$ & $14,327,317$ & $1,496,685$ & $11.7 \%$ \\
\hline
\end{tabular}


PLANNING TRANSPORTATION TO MEET THE NEEDS OF AN AGING ILLINOIS: AN ASSESSMENT

Appendix B, Continued: Summary of Alternative G Projection by HSTP Regions

\begin{tabular}{|ccccr|}
\hline HSTP Region & Total Population $\mathbf{6 5}$ as Percent of Total Population & & \\
& $\mathbf{2 0 0 0}$ & $\mathbf{2 0 1 0}$ & $\mathbf{2 0 2 0}$ & $\mathbf{2 0 3 0}$ \\
\hline $\mathbf{0}$ & $10.8 \%$ & $11.3 \%$ & $14.6 \%$ & $18.5 \%$ \\
$\mathbf{1}$ & $13.5 \%$ & $14.7 \%$ & $18.8 \%$ & $22.7 \%$ \\
$\mathbf{3}$ & $15.6 \%$ & $16.8 \%$ & $20.9 \%$ & $24.8 \%$ \\
$\mathbf{4}$ & $13.2 \%$ & $12.5 \%$ & $14.4 \%$ & $17.4 \%$ \\
$\mathbf{5}$ & $16.9 \%$ & $17.2 \%$ & $20.2 \%$ & $23.3 \%$ \\
$\mathbf{6}$ & $15.4 \%$ & $15.5 \%$ & $19.2 \%$ & $22.6 \%$ \\
$\mathbf{7}$ & $12.6 \%$ & $12.8 \%$ & $16.3 \%$ & $20.3 \%$ \\
$\mathbf{8}$ & $14.6 \%$ & $15.1 \%$ & $19.1 \%$ & $23.3 \%$ \\
$\mathbf{9}$ & $13.8 \%$ & $14.2 \%$ & $17.7 \%$ & $21.2 \%$ \\
$\mathbf{1 0}$ & $15.2 \%$ & $15.3 \%$ & $18.8 \%$ & $23.3 \%$ \\
$\mathbf{1 1}$ & $17.7 \%$ & $17.9 \%$ & $21.8 \%$ & $26.6 \%$ \\
Total & $14.5 \%$ & $14.4 \%$ & $18.4 \%$ & $23.6 \%$ \\
& $12.1 \%$ & $12.5 \%$ & $15.9 \%$ & $19.7 \%$ \\
\hline
\end{tabular}


Appendix C: Summary of Alternative G Projection by AAA Areas

\begin{tabular}{|c|c|c|c|c|c|c|}
\hline \multicolumn{5}{|c|}{ Total Population 65+ } & \multicolumn{2}{|c|}{ 2010-2030 Change } \\
\hline AAA Area & 2000 & 2010 & 2020 & 2030 & Total & Percent \\
\hline Northwestern & 85,893 & 98,481 & 134167 & 173172 & 74,691 & $75.8 \%$ \\
\hline Northeastern & 263,566 & 352,480 & 549246 & 786248 & 433,768 & $123.1 \%$ \\
\hline Western & 78,161 & 80,533 & 101189 & 121252 & 40,719 & $50.6 \%$ \\
\hline Central & 61,063 & 63,178 & 82310 & 100417 & 37,239 & $58.9 \%$ \\
\hline East Central & 108,060 & 114,421 & 151890 & 191874 & 77,453 & $67.7 \%$ \\
\hline West Central & 22,329 & 21,950 & 26720 & 31584 & 9,634 & $43.9 \%$ \\
\hline Lincolnland & 69,099 & 71,407 & 94341 & 119568 & 48,161 & $67.4 \%$ \\
\hline Southwestern & 90,040 & 92,868 & 122825 & 161288 & 68,420 & $73.7 \%$ \\
\hline Midland & 24,120 & 24,455 & 32620 & 41234 & 16,779 & $68.6 \%$ \\
\hline Southeastern & 22,620 & 22,145 & 27184 & 34104 & 11,959 & $54.0 \%$ \\
\hline Egyptian & 46,214 & 46,966 & 61211 & 76465 & 29,499 & $62.8 \%$ \\
\hline Chicago, Age Options & 631,385 & 620,329 & 781354 & 991796 & 371,467 & $59.9 \%$ \\
\hline Total & $1,502,550$ & $1,609,213$ & $2,165,055$ & $2,829,004$ & $1,219,791$ & $75.8 \%$ \\
\hline
\end{tabular}

\begin{tabular}{|lrrrrrr|}
\hline \multicolumn{1}{c}{ Total Population } & & & & \multicolumn{2}{c|}{$\mathbf{2 0 1 0 - 2 0 3 0}$ Change } \\
AAA Area & $\mathbf{2 0 0 0}$ & $\mathbf{2 0 1 0}$ & $\mathbf{2 0 2 0}$ & $\mathbf{2 0 3 0}$ & \multicolumn{1}{c|}{ Total } & Percent \\
\hline Northwestern & 645,951 & 688,393 & 743,772 & 790,477 & 102,084 & $14.8 \%$ \\
Northeastern & $2,916,033$ & $3,400,223$ & $3,885,452$ & $4,229,713$ & 829,490 & $24.4 \%$ \\
Western & 486,962 & 479,943 & 496,459 & 507,345 & 27,402 & $5.7 \%$ \\
Central & 405,311 & 416,255 & 439,305 & 451,397 & 35,142 & $8.4 \%$ \\
East Central & 806,813 & 836,106 & 886,910 & 922,172 & 86,066 & $10.3 \%$ \\
West Central & 125,188 & 122,207 & 127,425 & 129,141 & 6,934 & $5.7 \%$ \\
Lincolnland & 456,762 & 459,225 & 484,158 & 502,235 & 43,010 & $9.4 \%$ \\
Southwestern & 645,976 & 676,017 & 712,777 & 723,914 & 47,897 & $7.1 \%$ \\
Midland & 152,619 & 148,461 & 152,805 & 157,133 & 8,672 & $5.8 \%$ \\
Southeastern & 123,441 & 121,131 & 123,570 & 125,582 & 4,451 & $3.7 \%$ \\
Egyptian & 289,117 & 287,996 & 300,425 & 310,671 & 22,675 & $7.9 \%$ \\
Chicago, Age Options & $5,386,673$ & $5,194,675$ & $5,284,203$ & $5,477,536$ & 282,861 & $5.4 \%$ \\
Total & $12,440,846$ & $12,830,632$ & $13,637,262$ & $14,327,317$ & $1,496,685$ & $11.7 \%$ \\
\hline
\end{tabular}


Appendix C, Continued: Summary of Alternative G Projection by AAA Areas

\begin{tabular}{|c|c|c|c|c|}
\hline \multirow[b]{2}{*}{ AAA Area } & \multicolumn{3}{|c|}{$65+$ as Percent of Total Population } & \multirow[b]{2}{*}{2030} \\
\hline & 2000 & 2010 & 2020 & \\
\hline Northwestern & $13.3 \%$ & $14.3 \%$ & $18.0 \%$ & $21.9 \%$ \\
\hline Northeastern & $9.0 \%$ & $10.4 \%$ & $14.1 \%$ & $18.6 \%$ \\
\hline Western & $16.1 \%$ & $16.8 \%$ & $20.4 \%$ & $23.9 \%$ \\
\hline Central & $15.1 \%$ & $15.2 \%$ & $18.7 \%$ & $22.2 \%$ \\
\hline East Central & $13.4 \%$ & $13.7 \%$ & $17.1 \%$ & $20.8 \%$ \\
\hline West Central & $17.8 \%$ & $18.0 \%$ & $21.0 \%$ & $24.5 \%$ \\
\hline Lincolnland & $15.1 \%$ & $15.5 \%$ & $19.5 \%$ & $23.8 \%$ \\
\hline Southwestern & $13.9 \%$ & $13.7 \%$ & $17.2 \%$ & $22.3 \%$ \\
\hline Midland & $15.8 \%$ & $16.5 \%$ & $21.3 \%$ & $26.2 \%$ \\
\hline Southeastern & $18.3 \%$ & $18.3 \%$ & $22.0 \%$ & $27.2 \%$ \\
\hline Egyptian & $16.0 \%$ & $16.3 \%$ & $20.4 \%$ & $24.6 \%$ \\
\hline Chicago, Age Options & $11.7 \%$ & $11.9 \%$ & $14.8 \%$ & $18.1 \%$ \\
\hline Total & $12.1 \%$ & $12.5 \%$ & $15.9 \%$ & $19.7 \%$ \\
\hline
\end{tabular}


Appendix D: Population in Adams County

\begin{tabular}{|c|c|c|c|c|c|c|}
\hline Age & $35-44$ & $45-54$ & $55-64$ & $65-74$ & $75-84$ & $85+$ \\
\hline 2000 & 10,044 & 8,911 & 6,379 & 5,608 & 4,519 & 1,919 \\
\hline 2010 & 7,916 & 9,822 & 8,419 & 5,650 & 4,074 & 2,023 \\
\hline \multicolumn{7}{|l|}{ DCEO Projections } \\
\hline DCEO 2010 & 8,082 & 9,931 & 8,317 & 5,640 & 3,937 & 2,277 \\
\hline DCEO 2020 & 8,823 & 8,223 & 9,498 & 7,586 & 4,254 & 2,412 \\
\hline DCEO 2030 & 9,067 & 8,599 & 7,589 & 8,477 & 5,628 & 2,555 \\
\hline \multicolumn{7}{|l|}{$2000-2010$} \\
\hline \multicolumn{7}{|l|}{ Cohort Rate of Change } \\
\hline Actual Rate & & $-2.21 \%$ & $-5.52 \%$ & $-11.43 \%$ & $-27.35 \%$ & $-55.23 \%$ \\
\hline DCEO Rate & & $-1.13 \%$ & $-6.67 \%$ & $-11.58 \%$ & $-29.80 \%$ & $-49.61 \%$ \\
\hline cohort difference & & $-1.09 \%$ & $1.14 \%$ & $0.16 \%$ & $2.44 \%$ & $-5.62 \%$ \\
\hline half difference & & $-0.54 \%$ & $0.57 \%$ & $0.08 \%$ & $1.22 \%$ & $-2.81 \%$ \\
\hline quarter difference & & $-0.27 \%$ & $0.29 \%$ & $0.04 \%$ & $0.61 \%$ & $-1.41 \%$ \\
\hline \multicolumn{7}{|l|}{ DCEO Rates of Change } \\
\hline $2010-2020$ & & $1.74 \%$ & $-4.36 \%$ & $-8.79 \%$ & $-24.57 \%$ & $-38.74 \%$ \\
\hline $2020-2030$ & & $-2.54 \%$ & $-7.71 \%$ & $-10.75 \%$ & $-25.81 \%$ & $-39.94 \%$ \\
\hline \multicolumn{7}{|l|}{ ALTERNATIVE E } \\
\hline 2020 Population & & 8,054 & 9,394 & 7,679 & 4,262 & 2,496 \\
\hline 2030 Population & & & 7,433 & 8,384 & 5,697 & 2,560 \\
\hline \multicolumn{7}{|l|}{ ALTERNATIVE F } \\
\hline 2010-2020 Rate of Change & & $0.66 \%$ & $-3.22 \%$ & $-8.63 \%$ & $-22.13 \%$ & $-44.36 \%$ \\
\hline 2020 Population & & 7,968 & 9,506 & 7,692 & 4,400 & 2,267 \\
\hline 2020-2030 Rate of Change & & $-3.62 \%$ & $-6.57 \%$ & $-10.59 \%$ & $-23.37 \%$ & $-45.56 \%$ \\
\hline 2030 Population & & & 7,445 & 8,499 & 5,895 & 2,395 \\
\hline \multicolumn{7}{|l|}{ ALTERNATIVE G } \\
\hline 2010-2020 Rate of Change & & $1.20 \%$ & $-3.79 \%$ & $-8.71 \%$ & $-23.35 \%$ & $-41.55 \%$ \\
\hline 2020 Population & & 8,011 & 9,450 & 7,686 & 4,331 & 2,381 \\
\hline 2020-2030 Rate of Change & & $-2.81 \%$ & $-7.42 \%$ & $-10.71 \%$ & $-25.20 \%$ & $-41.34 \%$ \\
\hline 2030 Population & & & 7,416 & 8,438 & 5,749 & 2,540 \\
\hline
\end{tabular}


Appendix E: Projected Senior Population in Nursing Homes, Group Quarters, Living Alone, Living in Multiple Person Households, and Participating in the Labor Force for HSTP Regions (Alt G)

\begin{tabular}{|c|c|c|c|c|c|c|c|c|c|c|}
\hline \multirow[b]{2}{*}{ HSTP Region } & \multirow[b]{2}{*}{ Age } & \multicolumn{3}{|c|}{$\begin{array}{c}\text { Population in Nursing } \\
\text { Homes }\end{array}$} & \multicolumn{3}{|c|}{$\begin{array}{c}\text { Population in Group } \\
\text { Quarters }\end{array}$} & \multicolumn{3}{|c|}{ One Person Households } \\
\hline & & 2010 & 2020 & 2030 & 2010 & 2020 & 2030 & 2010 & 2020 & 2030 \\
\hline 0 & $65-74$ & 6,018 & 8,873 & 10,614 & 7,570 & 11,174 & 13,385 & 114,238 & 169,843 & 204,507 \\
\hline 1 & $65-74$ & 345 & 504 & 581 & 399 & 583 & 671 & 7,244 & 10,545 & 12,131 \\
\hline 2 & $65-74$ & 265 & 365 & 383 & 284 & 391 & 411 & 5,232 & 7,193 & 7,551 \\
\hline 3 & $65-74$ & 308 & 459 & 569 & 477 & 711 & 873 & 6,957 & 10,635 & 13,541 \\
\hline 4 & $65-74$ & 197 & 265 & 286 & 285 & 385 & 421 & 3,234 & 4,316 & 4,574 \\
\hline 5 & $65-74$ & 489 & 697 & 736 & 590 & 838 & 884 & 8,168 & 11,723 & 12,357 \\
\hline 6 & $65-74$ & 327 & 492 & 591 & 475 & 714 & 856 & 5,325 & 8,185 & 9,867 \\
\hline 7 & $65-74$ & 293 & 430 & 482 & 430 & 637 & 715 & 6,569 & 9,847 & 11,080 \\
\hline 8 & $65-74$ & 501 & 719 & 787 & 602 & 869 & 949 & 9,625 & 14,025 & 15,428 \\
\hline 9 & $65-74$ & 482 & 678 & 812 & 616 & 869 & 1,041 & 8,619 & 12,193 & 14,654 \\
\hline 10 & $65-74$ & 232 & 302 & 358 & 327 & 427 & 501 & 4,331 & 5,640 & 6,551 \\
\hline 11 & $65-74$ & 615 & 900 & 1,065 & 900 & 1,306 & 1,527 & 11,286 & 16,440 & 19,387 \\
\hline Total & & 10,072 & 14,684 & 17,264 & 12,955 & 18,905 & 22,234 & 190,828 & 280,584 & 331,625 \\
\hline 0 & $75+$ & 24,150 & 29,307 & 42,147 & 26,726 & 32,383 & 46,610 & 154,962 & 184,696 & 276,483 \\
\hline 1 & $75+$ & 2,138 & 2,854 & 4,088 & 2,190 & 2,920 & 4,182 & 11,115 & 14,163 & 20,561 \\
\hline 2 & $75+$ & 1,516 & 1,774 & 2,343 & 1,557 & 1,823 & 2,408 & 8,950 & 10,266 & 13,955 \\
\hline 3 & 75+ & 2,409 & 2,844 & 3,968 & 2,661 & 3,126 & 4,344 & 11,083 & 13,616 & 20,213 \\
\hline 4 & 75+ & 1,722 & 1,919 & 2,319 & 1,822 & 2,027 & 2,455 & 5,834 & 6,412 & 8,253 \\
\hline 5 & 75+ & 3,212 & 3,807 & 5,158 & 3,351 & 3,978 & 5,391 & 13,413 & 15,429 & 21,713 \\
\hline 6 & 75+ & 2,264 & 2,839 & 3,880 & 2,392 & 3,002 & 4,124 & 8,659 & 10,594 & 15,545 \\
\hline 7 & 75+ & 2,232 & 2,586 & 3,518 & 2,459 & 2,861 & 3,926 & 9,748 & 11,329 & 16,374 \\
\hline 8 & $75+$ & 3,175 & 3,765 & 5,104 & 3,362 & 3,980 & 5,401 & 15,712 & 18,227 & 25,926 \\
\hline 9 & 75+ & 3,124 & 3,930 & 5,300 & 3,247 & 4,074 & 5,497 & 14,484 & 17,044 & 23,842 \\
\hline 10 & 75+ & 1,405 & 1,756 & 2,252 & 1,526 & 1,893 & 2,431 & 7,378 & 8,594 & 11,423 \\
\hline 11 & 75+ & 3,498 & 4,498 & 6,297 & 3,967 & 5,094 & 7,140 & 16,690 & 20,311 & 29,414 \\
\hline Total & & 50,845 & 61,878 & 86,375 & 55,260 & 67,161 & 93,907 & 278,028 & 330,681 & 483,703 \\
\hline
\end{tabular}

All projections are derived from Alternative $\mathrm{G}$ assuming constant 2010 propensities at the county level. Data for 2010 are derived from Bureau of Census products:

-Population in Nursing Homes by Age - 2010 Census Summary File 1, Table PC05

-Population in Group Quarters by Age - 2010 Census Summary File 1, Table PC01

-One Person Households by Age - 2010 Census Summary File 1, Tables P25 and P26

-Two or More Person Households - derived from 2010 Census by subtracting one person households and group quarters population from total population

-Labor Force - estimated by applying to 2010 Decennial Census data, labor force participation rates from 5 Year American Community Survey, 2008-2012,Table BC23004 
Appendix E, Continued: Projected Senior Population in Nursing Homes, Group Quarters, Living Alone, Living in Multiple Person Households, and Participating in the Labor Force for HSTP Regions (Alt G)

\begin{tabular}{|c|c|c|c|c|c|c|c|}
\hline \multirow[b]{2}{*}{ HSTP Region } & \multirow[b]{2}{*}{ Age } & \multicolumn{3}{|c|}{ Two + Person Households } & \multicolumn{3}{|c|}{ Labor Force } \\
\hline & & 2010 & 2020 & 2030 & 2010 & 2020 & 2030 \\
\hline 0 & $65-74$ & 383,875 & 579,726 & 706,827 & 140,186 & 211,712 & 257,505 \\
\hline 1 & $65-74$ & 26,533 & 38,600 & 44,585 & 8,627 & 12,549 & 14,499 \\
\hline 2 & $65-74$ & 17,915 & 24,589 & 25,862 & 5,038 & 6,900 & 7,260 \\
\hline 3 & $65-74$ & 26,522 & 41,142 & 53,295 & 8,863 & 13,826 & 18,028 \\
\hline 4 & $65-74$ & 11,477 & 15,276 & 16,198 & 4,046 & 5,403 & 5,740 \\
\hline 5 & $65-74$ & 28,289 & 40,638 & 43,041 & 8,904 & 12,839 & 13,627 \\
\hline 6 & $65-74$ & 18,311 & 28,090 & 33,831 & 5,712 & 8,717 & 10,498 \\
\hline 7 & $65-74$ & 19,911 & 29,575 & 33,256 & 7,133 & 10,676 & 12,024 \\
\hline 8 & $65-74$ & 32,105 & 46,543 & 51,301 & 9,855 & 14,434 & 15,919 \\
\hline 9 & $65-74$ & 30,309 & 42,884 & 51,509 & 8,535 & 12,088 & 14,535 \\
\hline 10 & $65-74$ & 14,500 & 18,971 & 22,173 & 4,067 & 5,327 & 6,257 \\
\hline 11 & $65-74$ & 36,005 & 52,379 & 61,929 & 10,374 & 15,205 & 17,962 \\
\hline Total & & 645,752 & 958,415 & $1,143,805$ & 221,339 & 329,678 & 393,853 \\
\hline 0 & $75+$ & 256,273 & 307,705 & 464,635 & 26,606 & 32,153 & 48,437 \\
\hline 1 & $75+$ & 16,650 & 21,214 & 30,928 & 1,732 & 2,225 & 3,229 \\
\hline 2 & $75+$ & 11,815 & 13,527 & 18,452 & 1,036 & 1,191 & 1,617 \\
\hline 3 & $75+$ & 16,404 & 20,695 & 31,436 & 2,058 & 2,583 & 3,909 \\
\hline 4 & $75+$ & 7,466 & 8,173 & 10,642 & 1,045 & 1,154 & 1,481 \\
\hline 5 & $75+$ & 19,129 & 21,966 & 31,150 & 1,951 & 2,247 & 3,172 \\
\hline 6 & $75+$ & 11,817 & 14,393 & 21,393 & 1,181 & 1,449 & 2,131 \\
\hline 7 & $75+$ & 12,927 & 15,057 & 21,990 & 1,397 & 1,617 & 2,311 \\
\hline 8 & $75+$ & 21,273 & 24,612 & 35,300 & 2,342 & 2,725 & 3,896 \\
\hline 9 & $75+$ & 20,172 & 23,483 & 33,037 & 1,975 & 2,316 & 3,240 \\
\hline 10 & $75+$ & 9,320 & 10,731 & 14,292 & 973 & 1,132 & 1,489 \\
\hline 11 & $75+$ & 23,144 & 27,752 & 40,473 & 2,320 & 2,775 & 4,022 \\
\hline Total & & 426,390 & 509,308 & 753,729 & 44,615 & 53,567 & 78,934 \\
\hline
\end{tabular}

All projections are derived from Alternative $\mathrm{G}$ assuming constant 2010 propensities at the county level.

Data for 2010 are derived from Bureau of Census products:

-Population in Nursing Homes by Age - 2010 Census Summary File 1, Table PC05

-Population in Group Quarters by Age - 2010 Census Summary File 1, Table PC01

-One Person Households by Age - 2010 Census Summary File 1, Tables P25 and P26

-Two or More Person Households - derived from 2010 Census by subtracting one person households and group quarters population from total population

-Labor Force - estimated by applying to 2010 Decennial Census data, labor force participation rates from 5 Year American Community Survey, 2008-2012,Table BC23004 
Appendix F: Projected Senior Population in Nursing Homes, Group Quarters, Living Alone, Living in Multiple Person Households, and Participating in the Labor Force for AAA Areas (Alt G)

\begin{tabular}{|c|c|c|c|c|c|c|c|c|c|c|}
\hline \multirow[b]{2}{*}{ AAA Area } & \multirow[b]{2}{*}{ Age } & \multicolumn{3}{|c|}{$\begin{array}{c}\text { Population in Nursing } \\
\text { Homes }\end{array}$} & \multicolumn{3}{|c|}{$\begin{array}{c}\text { Population in Group } \\
\text { Quarters }\end{array}$} & \multicolumn{3}{|c|}{ One Person Households } \\
\hline & & 2010 & 2020 & 2030 & 2010 & 2020 & 2030 & 2010 & 2020 & 2030 \\
\hline Northwestern & $65-74$ & 532 & 778 & 911 & 727 & 1,065 & 1,245 & 10898 & 15,916 & 18,580 \\
\hline Northeastern & $65-74$ & 1,743 & 2,869 & 3,704 & 2,277 & 3,749 & 4,844 & 36701 & 61,210 & 79,956 \\
\hline Western & $65-74$ & 473 & 652 & 698 & 547 & 754 & 808 & 9352 & 12,878 & 13,834 \\
\hline Central & $65-74$ & 407 & 587 & 627 & 476 & 686 & 732 & 7007 & 10,174 & 10,814 \\
\hline East Central & $65-74$ & 698 & 1,014 & 1,145 & 836 & 1,219 & 1,374 & 13260 & 19,650 & 22,263 \\
\hline West Central & $65-74$ & 163 & 220 & 243 & 247 & 334 & 373 & 2304 & 3,089 & 3,408 \\
\hline Lincolnland & $65-74$ & 426 & 617 & 710 & 585 & 855 & 980 & 8691 & 12,830 & 14,687 \\
\hline Southwestern & $65-74$ & 588 & 882 & 1,074 & 767 & 1,143 & 1,388 & 10771 & 16,100 & 19,669 \\
\hline Midland & $65-74$ & 180 & 244 & 280 & 246 & 336 & 381 & 2759 & 3,774 & 4,305 \\
\hline Southeastern & $65-74$ & 119 & 154 & 190 & 166 & 217 & 266 & 2429 & 3,195 & 3,820 \\
\hline Egyptian & $65-74$ & 304 & 407 & 455 & 502 & 679 & 758 & 6040 & 8,083 & 9,021 \\
\hline Chicago, Age Options & $65-74$ & 4,439 & 6,260 & 7,228 & 5,579 & 7,868 & 9,084 & 80616 & 113,685 & 131,268 \\
\hline Total & & 10,072 & 14,684 & 17,264 & 12,955 & 18,905 & 22,234 & 190828 & 280,584 & 331,625 \\
\hline Northwestern & $75+$ & 3,486 & 4,497 & 6,388 & 3,613 & 4,650 & 6,606 & 17,254 & 21,567 & 31,200 \\
\hline Northeastern & $75+$ & 9,549 & 13,246 & 20,428 & 10,286 & 14,289 & 22,087 & 52,074 & 73,410 & 118,220 \\
\hline Western & $75+$ & 3,179 & 3,676 & 4,775 & 3,426 & 3,956 & 5,137 & 15,799 & 17,929 & 24,226 \\
\hline Central & $75+$ & 2,747 & 3,211 & 4,387 & 2,856 & 3,345 & 4,570 & 11,456 & 13,123 & 18,655 \\
\hline East Central & $75+$ & 4,713 & 5,632 & 7,589 & 4,988 & 5,960 & 8,055 & 21,723 & 25,440 & 36,460 \\
\hline West Central & $75+$ & 1,386 & 1,531 & 1,832 & 1,485 & 1,638 & 1,967 & 4,163 & 4,567 & 5,852 \\
\hline Lincolnland & $75+$ & 3,193 & 3,778 & 5,108 & 3,434 & 4,069 & 5,538 & 13,450 & 15,681 & 22,378 \\
\hline Southwestern & $75+$ & 3,578 & 4,468 & 6,037 & 3,914 & 4,895 & 6,634 & 16,836 & 19,269 & 27,655 \\
\hline Midland & $75+$ & 1,053 & 1,512 & 2,118 & 1,108 & 1,574 & 2,198 & 4,693 & 6,085 & 8,549 \\
\hline Southeastern & $75+$ & 858 & 1,069 & 1,351 & 910 & 1,128 & 1,429 & 4,478 & 5,093 & 6,729 \\
\hline Egyptian & $75+$ & 1,519 & 1,882 & 2,675 & 1,775 & 2,195 & 3,116 & 8,677 & 10,960 & 15,502 \\
\hline Chicago, Age Options & $75+$ & 15,584 & 17,376 & 23,687 & 17,465 & 19,463 & 26,570 & 107,425 & 117,558 & 168,279 \\
\hline Total & & 50,845 & 61,878 & 86,375 & 55,260 & 67,161 & 93,907 & 278,028 & 330,681 & 483,703 \\
\hline
\end{tabular}

All projections are derived from Alternative $\mathrm{G}$ assuming constant 2010 propensities at the county level.

Data for 2010 are derived from Bureau of Census products:

-Population in Nursing Homes by Age - 2010 Census Summary File 1, Table PC05

-Population in Group Quarters by Age - 2010 Census Summary File 1, Table PC01

-One Person Households by Age - 2010 Census Summary File 1, Tables P25 and P26

-Two or More Person Households - derived from 2010 Census by subtracting one person households and group quarters population from total population

-Labor Force - estimated by applying to 2010 Decennial Census data, labor force participation rates from 5 Year American Community Survey, 2008-2012,Table BC23004 
Appendix F, Continued: Projected Senior Population in Nursing Homes, Group Quarters, Living Alone, Living in Multiple Person Households, and Participating in the Labor Force for AAA Areas (Alt G)

\begin{tabular}{|c|c|c|c|c|c|c|c|}
\hline \multirow[b]{2}{*}{ AAA Area } & \multirow[b]{2}{*}{ Age } & \multicolumn{3}{|c|}{ Two + Person Households } & \multicolumn{3}{|c|}{ Labor Force } \\
\hline & & 2010 & 2020 & 2030 & 2010 & 2020 & 2030 \\
\hline Northwestern & $65-74$ & 40,510 & 59,071 & 69,159 & 12,895 & 18,840 & 22,105 \\
\hline Northeastern & $65-74$ & 158,368 & 265,056 & 347,886 & 58,763 & 98,061 & 127,863 \\
\hline Western & $65-74$ & 30,820 & 42,385 & 45,578 & 9,390 & 12,914 & 13,953 \\
\hline Central & $65-74$ & 24,700 & 35,849 & 38,272 & 7,984 & 11,612 & 12,405 \\
\hline East Central & $65-74$ & 44,395 & 65,514 & 74,333 & 13,766 & 20,425 & 23,188 \\
\hline West Central & $65-74$ & 8,347 & 11,172 & 12,291 & 2,963 & 3,979 & 4,374 \\
\hline Lincolnland & $65-74$ & 27,345 & 40,034 & 45,915 & 8,892 & 13,142 & 15,003 \\
\hline Southwestern & $65-74$ & 35,905 & 53,564 & 65,519 & 10,999 & 16,412 & 20,054 \\
\hline Midland & $65-74$ & 9,660 & 13,210 & 15,080 & 2,835 & 3,886 & 4,437 \\
\hline Southeastern & $65-74$ & 8,512 & 11,196 & 13,415 & 2,474 & 3,241 & 3,877 \\
\hline Egyptian & $65-74$ & 18,864 & 25,274 & 28,289 & 4,793 & 6,475 & 7,235 \\
\hline Chicago, Age Options & $65-74$ & 238,326 & 336,089 & 388,068 & 85,585 & 120,692 & 139,358 \\
\hline Total & & 645,752 & 958,415 & $1,143,805$ & 221,339 & 329,678 & 393,853 \\
\hline Northwestern & $75+$ & 25,479 & 31,898 & 46,383 & 2,708 & 3,397 & 4,916 \\
\hline Northeastern & $75+$ & 92,774 & 131,531 & 213,256 & 10,546 & 14,878 & 23,974 \\
\hline Western & $75+$ & 20,589 & 23,286 & 31,667 & 2,160 & 2,450 & 3,302 \\
\hline Central & $75+$ & 16,683 & 19,134 & 27,374 & 1,730 & 1,986 & 2,827 \\
\hline East Central & $75+$ & 29,219 & 34,106 & 49,389 & 3,138 & 3,681 & 5,296 \\
\hline West Central & $75+$ & 5,404 & 5,920 & 7,694 & 744 & 815 & 1,043 \\
\hline Lincolnland & $75+$ & 17,902 & 20,872 & 30,070 & 1,813 & 2,103 & 2,980 \\
\hline Southwestern & $75+$ & 24,675 & 27,854 & 40,423 & 2,595 & 2,967 & 4,261 \\
\hline Midland & $75+$ & 5,989 & 7,641 & 10,720 & 578 & 744 & 1,041 \\
\hline Southeastern & $75+$ & 5,650 & 6,355 & 8,445 & 666 & 767 & 1,005 \\
\hline Egyptian & $75+$ & 11,108 & 14,020 & 19,780 & 996 & 1,239 & 1,750 \\
\hline Chicago, Age Options & $75+$ & 170,918 & 186,690 & 268,527 & 16,942 & 18,540 & 26,539 \\
\hline Total & & 426,390 & 509,308 & 753,729 & 44,615 & 53,567 & 78,934 \\
\hline
\end{tabular}

All projections are derived from Alternative $\mathrm{G}$ assuming constant 2010 propensities at the county level.

Data for 2010 are derived from Bureau of Census products:

-Population in Nursing Homes by Age - 2010 Census Summary File 1, Table PC05

-Population in Group Quarters by Age - 2010 Census Summary File 1, Table PC01

-One Person Households by Age - 2010 Census Summary File 1, Tables P25 and P26

-Two or More Person Households - derived from 2010 Census by subtracting one person households and group quarters population from total population

-Labor Force - estimated by applying to 2010 Decennial Census data, labor force participation rates from 5 Year American Community Survey, 2008-2012,Table BC23004 
Appendix G: Total Population in Illinois Counties, 2000 - 2030

\begin{tabular}{|c|c|c|c|c|c|c|c|c|c|c|c|}
\hline \multirow[b]{2}{*}{ County } & \multirow[b]{2}{*}{2000} & \multicolumn{2}{|c|}{2010} & \multicolumn{4}{|c|}{2020} & \multicolumn{4}{|c|}{2030} \\
\hline & & DCEO & CENSUS & DCEO & ALT E & ALT F & ALT G & DCEO & ALT E & ALT F & ALT G \\
\hline Total & $12,440,846$ & $13,279,091$ & $12,830,632$ & $14,316,487$ & $13,836,845$ & $13,437,679$ & $13,637,262$ & $15,138,849$ & $14,630,070$ & $13,904,150$ & $14,327,317$ \\
\hline Adams & 68,390 & 70,212 & 67,103 & 76,273 & 72,896 & 69,845 & 71,370 & 78,397 & 74,926 & 68,615 & 72,547 \\
\hline Alexander & 9,590 & 9,501 & 8,238 & 9,933 & 8,613 & 7,528 & 8,070 & 10,464 & 9,073 & 6,939 & 8,236 \\
\hline Bond & 17,664 & 17,804 & 17,768 & 19,154 & 19,115 & 19,079 & 19,097 & 20,064 & 20,023 & 19,947 & 19,995 \\
\hline Boone & 41,852 & 45,484 & 54,165 & 48,540 & 57,804 & 69,039 & 63,422 & 52,161 & 62,116 & 88,510 & 71,442 \\
\hline Brown & 6,951 & 7,015 & 6,937 & 7,404 & 7,322 & 7,244 & 7,283 & 7,689 & 7,604 & 7,441 & 7,543 \\
\hline Bureau & 35,561 & 36,427 & 34,978 & 38,631 & 37,094 & 35,669 & 36,382 & 40,820 & 39,196 & 36,237 & 38,073 \\
\hline Calhoun & 5,084 & 5,018 & 5,089 & 5,260 & 5,334 & 5,405 & 5,370 & 5,572 & 5,651 & 5,802 & 5,707 \\
\hline Carroll & 16,705 & 16,368 & 15,387 & 17,003 & 15,984 & 15,080 & 15,532 & 17,729 & 16,666 & 14,839 & 15,967 \\
\hline Cass & 13,723 & 14,722 & 13,642 & 15,538 & 14,398 & 13,325 & 13,861 & 16,064 & 14,886 & 12,727 & 14,058 \\
\hline Champaign & 179,981 & 194,234 & 201,081 & 209,833 & 217,230 & 224,880 & 221,055 & 216,958 & 224,606 & 241,071 & 230,663 \\
\hline Christian & 35,431 & 38,094 & 34,800 & 40,053 & 36,590 & 33,354 & 34,972 & 40,601 & 37,090 & 30,710 & 34,638 \\
\hline Clark & 17,041 & 18,612 & 16,335 & 19,791 & 17,370 & 15,187 & 16,278 & 20,398 & 17,903 & 13,624 & 16,234 \\
\hline Clay & 14,592 & 14,827 & 13,815 & 15,537 & 14,477 & 13,518 & 13,997 & 15,927 & 14,840 & 12,920 & 14,106 \\
\hline Clinton & 35,593 & 40,058 & 37,762 & 43,075 & 40,606 & 38,170 & 39,388 & 44,621 & 42,063 & 37,078 & 40,167 \\
\hline Coles & 53,285 & 54,878 & 53,873 & 58,030 & 56,967 & 55,951 & 56,459 & 59,746 & 58,652 & 56,550 & 57,863 \\
\hline Cook & $5,386,673$ & $5,472,429$ & $5,194,675$ & $5,707,832$ & $5,418,130$ & $5,150,276$ & $5,284,203$ & $5,990,243$ & $5,686,207$ & $5,139,536$ & $5,477,536$ \\
\hline Crawford & 20,485 & 21,363 & 19,817 & 22,407 & 20,785 & 19,290 & 20,038 & 22,683 & 21,041 & 18,072 & 19,906 \\
\hline Cumberland & 11,275 & 11,687 & 11,048 & 12,475 & 11,793 & 11,167 & 11,480 & 13,182 & 12,461 & 11,167 & 11,968 \\
\hline DeKalb & 89,118 & 101,735 & 105,160 & 114,992 & 118,863 & 122,905 & 120,884 & 124,200 & 128,381 & 137,470 & 131,725 \\
\hline De Witt & 16,829 & 17,885 & 16,561 & 18,914 & 17,514 & 16,211 & 16,862 & 19,768 & 18,305 & 15,667 & 17,292 \\
\hline Douglas & 19,955 & 21,823 & 19,980 & 23,495 & 21,511 & 19,665 & 20,588 & 24,607 & 22,529 & 18,780 & 21,087 \\
\hline DuPage & 905,764 & 948,549 & 916,924 & $1,010,323$ & 976,638 & 944,624 & 960,631 & $1,034,039$ & 999,564 & 933,816 & 974,795 \\
\hline Edgar & 19,738 & 19,363 & 18,576 & 19,632 & 18,834 & 18,093 & 18,464 & 19,811 & 19,006 & 17,537 & 18,448 \\
\hline Edwards & 6,971 & 7,219 & 6,721 & 7,514 & 6,996 & 6,516 & 6,756 & 7,760 & 7,225 & 6,263 & 6,856 \\
\hline Effingham & 34,322 & 38,374 & 34,242 & 42,191 & 37,648 & 33,526 & 35,587 & 44,752 & 39,933 & 31,525 & 36,676 \\
\hline Fayette & 21,837 & 21,865 & 22,140 & 22,319 & 22,600 & 22,879 & 22,739 & 22,570 & 22,854 & 23,424 & 23,066 \\
\hline Ford & 14,272 & 14,706 & 14,081 & 15,530 & 14,870 & 14,253 & 14,562 & 16,015 & 15,334 & 14,074 & 14,857 \\
\hline Franklin & 39,084 & 41,148 & 39,561 & 44,535 & 42,817 & 41,211 & 42,014 & 46,739 & 44,936 & 41,577 & 43,667 \\
\hline Fulton & 38,315 & 38,140 & 37,069 & 39,621 & 38,508 & 37,472 & 37,990 & 40,946 & 39,796 & 37,678 & 38,995 \\
\hline Gallatin & 6,445 & 6,421 & 5,589 & 6,414 & 5,583 & 4,861 & 5,222 & 6,554 & 5,705 & 4,340 & 5,168 \\
\hline Greene & 14,791 & 14,641 & 13,886 & 14,872 & 14,105 & 13,396 & 13,751 & 14,958 & 14,187 & 12,790 & 13,655 \\
\hline Grundy & 37,599 & 41,650 & 50,063 & 46,454 & 55,837 & 67,039 & 61,438 & 50,414 & 60,597 & 87,755 & 70,112 \\
\hline Hamilton & 8,632 & 8,931 & 8,457 & 9,374 & 8,876 & 8,412 & 8,644 & 9,751 & 9,233 & 8,288 & 8,873 \\
\hline Hancock & 20,155 & 21,662 & 19,104 & 22,692 & 20,012 & 17,588 & 18,800 & 22,454 & 19,802 & 15,171 & 18,006 \\
\hline Hardin & 4,800 & 4,805 & 4,320 & 5,167 & 4,645 & 4,209 & 4,427 & 5,570 & 5,008 & 4,112 & 4,661 \\
\hline Henderson & 8,221 & 8,337 & 7,331 & 8,884 & 7,812 & 6,915 & 7,363 & 9,527 & 8,377 & 6,569 & 7,671 \\
\hline Henry & 51,107 & 50,707 & 50,486 & 52,418 & 52,190 & 51,971 & 52,080 & 54,321 & 54,084 & 53,633 & 53,915 \\
\hline Iroquois & 31,386 & 32,524 & 29,718 & 34,609 & 31,623 & 28,966 & 30,295 & 36,304 & 33,172 & 27,795 & 31,101 \\
\hline Jackson & 59,710 & 61,574 & 60,218 & 63,719 & 62,316 & 60,948 & 61,632 & 63,825 & 62,419 & 59,665 & 61,385 \\
\hline Jasper & 10,135 & 10,080 & 9,698 & 10,199 & 9,812 & 9,447 & 9,630 & 10,403 & 10,009 & 9,280 & 9,732 \\
\hline Jefferson & 40,106 & 40,772 & 38,827 & 43,792 & 41,703 & 39,820 & 40,761 & 46,800 & 44,567 & 40,624 & 43,067 \\
\hline Jersey & 21,706 & 24,334 & 22,985 & 28,280 & 26,712 & 25,284 & 25,998 & 31,071 & 29,349 & 26,208 & 28,160 \\
\hline Jo Daviess & 22,324 & 25,472 & 22,678 & 27,932 & 24,868 & 22,030 & 23,449 & 29,574 & 26,330 & 20,568 & 24,094 \\
\hline Johnson & 12,905 & 13,965 & 12,582 & 15,414 & 13,888 & 12,539 & 13,213 & 16,859 & 15,189 & 12,371 & 14,098 \\
\hline
\end{tabular}


Appendix G, Continued: Total Population in Illinois Counties, 2000 - 2030

\begin{tabular}{|c|c|c|c|c|c|c|c|c|c|c|c|}
\hline \multirow[b]{2}{*}{ County } & \multirow[b]{2}{*}{2000} & \multicolumn{2}{|c|}{2010} & \multicolumn{4}{|c|}{2020} & \multicolumn{4}{|c|}{2030} \\
\hline & & DCEO & CENSUS & DCEO & ALT E & ALT F & ALT G & DCEO & ALT E & ALT F & ALT G \\
\hline Kane & 404,834 & 516,914 & 515,269 & 630,563 & 628,556 & 626,463 & 627,509 & 679,403 & 677,241 & 672,439 & 675,475 \\
\hline Kankakee & 104,010 & 110,659 & 113,449 & 119,655 & 122,672 & 125,715 & 124,193 & 126,509 & 129,699 & 136,288 & 132,140 \\
\hline Kendall & 54,633 & 68,588 & 114,736 & 78,694 & 131,642 & 228,558 & 180,100 & 85,060 & 142,291 & 440,108 & 232,701 \\
\hline Knox & 55,928 & 55,666 & 52,919 & 57,732 & 54,883 & 52,284 & 53,583 & 60,122 & 57,155 & 51,880 & 55,144 \\
\hline Lake & 645,503 & 762,918 & 703,462 & 820,250 & 756,326 & 691,531 & 723,929 & 873,024 & 804,987 & 672,328 & 753,836 \\
\hline LaSalle & 111,700 & 118,385 & 113,924 & 131,155 & 126,213 & 121,663 & 123,938 & 141,615 & 136,279 & 126,507 & 132,585 \\
\hline Lawrence & 15,484 & 15,351 & 16,833 & 15,675 & 17,188 & 18,799 & 17,994 & 15,915 & 17,451 & 20,887 & 18,700 \\
\hline Lee & 36,118 & 36,554 & 36,031 & 37,939 & 37,396 & 36,874 & 37,135 & 38,923 & 38,366 & 37,297 & 37,964 \\
\hline Livingston & 39,743 & 40,838 & 38,950 & 43,199 & 41,202 & 39,352 & 40,277 & 45,162 & 43,074 & 39,270 & 41,629 \\
\hline Logan & 31,235 & 31,353 & 30,305 & 32,164 & 31,089 & 30,072 & 30,580 & 32,715 & 31,621 & 29,578 & 30,848 \\
\hline McDonough & 32,967 & 33,710 & 32,612 & 35,147 & 34,002 & 32,916 & 33,459 & 35,716 & 34,553 & 32,353 & 33,722 \\
\hline McHenry & 260,528 & 337,034 & 308,760 & 407,931 & 373,709 & 340,201 & 356,955 & 443,398 & 406,201 & 332,859 & 378,305 \\
\hline McLean & 150,696 & 168,611 & 169,572 & 187,086 & 188,152 & 189,234 & 188,693 & 199,102 & 200,237 & 202,594 & 201,113 \\
\hline Macon & 114,906 & 111,957 & 110,768 & 115,797 & 114,567 & 113,421 & 113,994 & 119,693 & 118,422 & 116,063 & 117,535 \\
\hline Macoupin & 49,103 & 51,161 & 47,765 & 55,948 & 52,234 & 48,931 & 50,583 & 59,442 & 55,496 & 48,602 & 52,867 \\
\hline Madison & 259,391 & 267,588 & 269,282 & 285,586 & 287,394 & 289,153 & 288,273 & 296,342 & 298,218 & 301,931 & 299,601 \\
\hline Marion & 41,762 & 43,324 & 39,437 & 45,651 & 41,555 & 37,885 & 39,720 & 47,285 & 43,043 & 35,715 & 40,217 \\
\hline Marshall & 13,209 & 13,370 & 12,640 & 14,024 & 13,258 & 12,560 & 12,909 & 14,340 & 13,557 & 12,149 & 13,022 \\
\hline Mason & 16,069 & 16,615 & 14,666 & 17,312 & 15,281 & 13,502 & 14,392 & 17,147 & 15,136 & 11,736 & 13,818 \\
\hline Massac & 15,191 & 17,164 & 15,429 & 17,820 & 16,019 & 14,257 & 15,138 & 18,649 & 16,764 & 13,291 & 15,410 \\
\hline Menard & 12,509 & 13,598 & 12,705 & 14,740 & 13,772 & 12,865 & 13,319 & 15,195 & 14,197 & 12,344 & 13,492 \\
\hline Mercer & 16,988 & 17,586 & 16,434 & 18,384 & 17,180 & 16,065 & 16,623 & 18,924 & 17,684 & 15,448 & 16,829 \\
\hline Monroe & 27,667 & 32,920 & 32,957 & 38,754 & 38,798 & 38,842 & 38,820 & 43,111 & 43,159 & 43,260 & 43,197 \\
\hline Montgomery & 30,704 & 30,729 & 30,104 & 31,744 & 31,098 & 30,486 & 30,792 & 33,124 & 32,450 & 31,190 & 31,974 \\
\hline Morgan & 36,676 & 37,696 & 35,547 & 39,474 & 37,224 & 35,141 & 36,182 & 40,429 & 38,124 & 33,932 & 36,528 \\
\hline Moultrie & 14,317 & 15,770 & 14,846 & 16,911 & 15,920 & 14,962 & 15,441 & 17,588 & 16,557 & 14,595 & 15,810 \\
\hline Ogle & 51,119 & 54,704 & 53,497 & 59,230 & 57,923 & 56,660 & 57,292 & 63,765 & 62,358 & 59,660 & 61,340 \\
\hline Peoria & 183,751 & 187,876 & 186,494 & 194,083 & 192,655 & 191,253 & 191,954 & 193,314 & 191,892 & 189,057 & 190,833 \\
\hline Perry & 23,130 & 23,065 & 22,350 & 23,913 & 23,172 & 22,481 & 22,826 & 24,913 & 24,141 & 22,726 & 23,604 \\
\hline Piatt & 16,396 & 17,023 & 16,729 & 17,748 & 17,441 & 17,142 & 17,291 & 18,034 & 17,723 & 17,110 & 17,493 \\
\hline Pike & 17,418 & 17,221 & 16,430 & 18,123 & 17,291 & 16,544 & 16,918 & 19,138 & 18,259 & 16,720 & 17,673 \\
\hline Pope & 4,413 & 4,774 & 4,470 & 5,106 & 4,781 & 4,473 & 4,627 & 5,245 & 4,911 & 4,287 & 4,673 \\
\hline Pulaski & 7,348 & 7,437 & 6,161 & 7,891 & 6,537 & 5,467 & 6,002 & 8,075 & 6,690 & 4,645 & 5,882 \\
\hline Putnam & 6,086 & 6,221 & 6,006 & 6,526 & 6,300 & 6,088 & 6,194 & 6,758 & 6,524 & 6,090 & 6,360 \\
\hline Randolph & 33,951 & 34,432 & 33,476 & 35,743 & 34,751 & 33,808 & 34,279 & 37,004 & 35,977 & 34,049 & 35,247 \\
\hline Richland & 16,181 & 16,401 & 16,233 & 17,169 & 16,993 & 16,825 & 16,909 & 17,867 & 17,684 & 17,334 & 17,552 \\
\hline Rock Island & 149,637 & 151,651 & 147,546 & 154,941 & 150,747 & 146,699 & 148,723 & 152,171 & 148,052 & 140,052 & 145,044 \\
\hline St. Clair & 256,532 & 254,235 & 270,056 & 253,924 & 269,726 & 286,381 & 278,053 & 243,453 & 258,603 & 292,233 & 270,874 \\
\hline Saline & 26,776 & 27,477 & 24,913 & 28,356 & 25,710 & 23,324 & 24,517 & 29,195 & 26,471 & 21,781 & 24,656 \\
\hline Sangamon & 189,278 & 195,115 & 197,465 & 210,672 & 213,209 & 215,661 & 214,435 & 222,367 & 225,045 & 230,311 & 227,005 \\
\hline Schuyler & 7,190 & 7,442 & 7,544 & 7,528 & 7,631 & 7,738 & 7,685 & 7,482 & 7,585 & 7,801 & 7,665 \\
\hline Scott & 5,537 & 5,847 & 5,355 & 6,039 & 5,531 & 5,055 & 5,293 & 6,060 & 5,550 & 4,623 & 5,194 \\
\hline Shelby & 22,931 & 23,274 & 22,363 & 24,116 & 23,172 & 22,284 & 22,728 & 24,471 & 23,513 & 21,726 & 22,837 \\
\hline Stark & 6,332 & 6,455 & 5,994 & 6,805 & 6,319 & 5,883 & 6,101 & 7,225 & 6,709 & 5,817 & 6,366 \\
\hline
\end{tabular}


Appendix G, Continued: Total Population in Illinois Counties, $2000-2030$

\begin{tabular}{|c|c|c|c|c|c|c|c|c|c|c|c|}
\hline \multirow[b]{2}{*}{ County } & \multirow[b]{2}{*}{2000} & \multicolumn{2}{|c|}{2010} & \multicolumn{4}{|c|}{2020} & \multicolumn{4}{|c|}{2030} \\
\hline & & DCEO & CENSUS & DCEO & ALT E & ALT F & ALT G & DCEO & ALT E & ALT F & ALT C \\
\hline Stephenson & 49,058 & 47,812 & 47,711 & 49,268 & 49,164 & 49,066 & 49,115 & 51,737 & 51,628 & 51,424 & 51,551 \\
\hline Tazewell & 128,175 & 139,616 & 135,394 & 154,567 & 149,893 & 145,433 & 147,663 & 165,373 & 160,372 & 150,810 & $156,77 \mathrm{C}$ \\
\hline Union & 18,326 & 18,809 & 17,808 & 20,454 & 19,365 & 18,393 & 18,879 & 21,617 & 20,467 & 18,434 & 19,695 \\
\hline Vermilion & 84,062 & 78,181 & 81,625 & 77,363 & 80,771 & 84,115 & 82,443 & 80,137 & 83,667 & 90,577 & $86,24<$ \\
\hline Wabash & 12,964 & 12,699 & 11,947 & 13,212 & 12,430 & 11,737 & 12,083 & 13,643 & 12,835 & 11,439 & 12,302 \\
\hline Warren & 18,767 & 20,113 & 17,707 & 21,864 & 19,249 & 16,978 & 18,113 & 22,431 & 19,748 & 15,242 & 18,003 \\
\hline Washington & 15,178 & 15,805 & 14,716 & 16,534 & 15,395 & 14,339 & 14,867 & 16,793 & 15,636 & 13,535 & 14,833 \\
\hline Wayne & 17,184 & 16,635 & 16,760 & 16,581 & 16,706 & 16,828 & 16,767 & 16,690 & 16,815 & 17,061 & 16,907 \\
\hline White & 15,405 & 16,019 & 14,665 & 16,816 & 15,395 & 14,106 & 14,750 & 17,189 & 15,736 & 13,179 & 14,75 \\
\hline Whiteside & 60,755 & 62,431 & 58,498 & 65,565 & 61,435 & 57,648 & 59,541 & 68,134 & 63,842 & 56,175 & 60,910 \\
\hline Will & 503,162 & 706,639 & 677,560 & 907,625 & 870,275 & 831,117 & 850,696 & $1,093,207$ & $1,048,220$ & 953,023 & $1,012,34$ \\
\hline Williamson & 61,399 & 65,497 & 66,357 & 72,441 & 73,392 & 74,322 & 73,857 & 77,760 & 78,781 & 80,820 & 79,538 \\
\hline Winnebago & 278,902 & 307,349 & 295,266 & 337,049 & 323,798 & 311,006 & 317,402 & 359,900 & 345,751 & 318,618 & 335,48 \\
\hline Woodford & 35,529 & 39,362 & 38,664 & 43,845 & 43,068 & 42,308 & 42,688 & 46,857 & 46,026 & 44,383 & 45,411 \\
\hline
\end{tabular}


Appendix H: Total Population Age 65-74 for Illinois Counties, 2000 - 2030

\begin{tabular}{|c|c|c|c|c|c|c|c|c|c|c|c|}
\hline \multirow[b]{2}{*}{ County } & \multirow[b]{2}{*}{2000} & \multicolumn{2}{|c|}{2010} & \multicolumn{4}{|c|}{2020} & \multicolumn{4}{|c|}{2030} \\
\hline & & DCEO & CENSUS & DCEO & ALT E & ALT F & ALT G & DCEO & ALT E & ALT F & ALT G \\
\hline Total & 773,562 & 853,480 & 849,535 & $1,264,716$ & $1,258,686$ & $1,257,122$ & $1,257,904$ & $1,530,307$ & $1,498,537$ & $1,499,321$ & $1,497,664$ \\
\hline Adams & 5,608 & 5,640 & 5,650 & 7,586 & 7,679 & 7,692 & 7,686 & 8,477 & 8,384 & 8,499 & 8,438 \\
\hline Alexander & 826 & 820 & 762 & 1,137 & 1,036 & 965 & 1,000 & 1,160 & 1,120 & 953 & 1,053 \\
\hline Bond & 1,319 & 1,250 & 1,345 & 1,895 & 1,924 & 2,061 & 1,992 & 2,154 & 2,200 & 2,391 & 2,255 \\
\hline Boone & 2,423 & 3,400 & 3,788 & 4,788 & 5,405 & 6,016 & 5,711 & 6,332 & 7,093 & 8,906 & 7,761 \\
\hline Brown & 415 & 422 & 457 & 646 & 580 & 625 & 603 & 691 & 863 & 838 & 836 \\
\hline Bureau & 2,922 & 3,203 & 3,134 & 4,353 & 4,373 & 4,281 & 4,327 & 4,797 & 4,696 & 4,617 & 4,682 \\
\hline Calhoun & 508 & 536 & 561 & 652 & 663 & 693 & 678 & 743 & 812 & 863 & 828 \\
\hline Carroll & 1,666 & 1,609 & 1,712 & 2,144 & 2,265 & 2,404 & 2,334 & 2,433 & 2,259 & 2,528 & 2,356 \\
\hline Cass & 1,055 & 1,096 & 1,093 & 1,389 & 1,378 & 1,374 & 1,376 & 1,557 & 1,530 & 1,514 & 1,523 \\
\hline Champaign & 9,129 & 9,910 & 10,280 & 16,327 & 16,872 & 17,475 & 17,174 & 17,657 & 18,681 & 19,988 & 19,158 \\
\hline Christian & 2,937 & 3,081 & 3,049 & 3,918 & 3,909 & 3,869 & 3,889 & 4,486 & 4,413 & 4,357 & 4,396 \\
\hline Clark & 1,468 & 1,867 & 1,542 & 2,594 & 2,113 & 1,725 & 1,919 & 2,908 & 2,833 & 1,860 & 2,442 \\
\hline Clay & 1,276 & 1,327 & 1,224 & 1,747 & 1,733 & 1,602 & 1,667 & 1,921 & 1,924 & 1,762 & 1,879 \\
\hline Clinton & 2,735 & 2,998 & 2,726 & 4,134 & 4,134 & 3,749 & 3,941 & 5,171 & 5,356 & 4,845 & 5,228 \\
\hline Coles & 3,517 & 3,634 & 3,707 & 5,097 & 5,171 & 5,273 & 5,222 & 5,553 & 5,439 & 5,626 & 5,505 \\
\hline Cook & 329,211 & 334,465 & 324,521 & 478,372 & 464,083 & 451,201 & 457,642 & 572,044 & 539,817 & 510,047 & 528,420 \\
\hline Crawford & 1,744 & 1,823 & 1,696 & 2,402 & 2,375 & 2,212 & 2,294 & 2,742 & 2,771 & 2,551 & 2,708 \\
\hline $\begin{array}{l}\text { Cumber- } \\
\text { land }\end{array}$ & 862 & 989 & 951 & 1,353 & 1,401 & 1,348 & 1,374 & 1,654 & 1,556 & 1,548 & 1,567 \\
\hline DeKalb & 4,293 & 4,686 & 5,395 & 7,221 & 8,183 & 9,358 & 8,770 & 10,216 & 10,155 & 13,098 & 11,194 \\
\hline De Witt & 1,300 & 1,506 & 1,512 & 1,974 & 1,897 & 1,904 & 1,901 & 2,376 & 2,332 & 2,250 & 2,289 \\
\hline Douglas & 1,622 & 1,624 & 1,577 & 2,088 & 2,118 & 2,057 & 2,087 & 2,434 & 2,389 & 2,352 & 2,388 \\
\hline DuPage & 45,637 & 58,494 & 57,640 & 94,975 & 94,931 & 93,638 & 94,284 & 117,133 & 113,503 & 111,916 & 113,093 \\
\hline Edgar & 1,640 & 1,759 & 1,805 & 2,320 & 2,421 & 2,482 & 2,451 & 2,687 & 2,556 & 2,732 & 2,626 \\
\hline Edwards & 625 & 743 & 596 & 975 & 959 & 766 & 862 & 1,050 & 1,043 & 818 & 982 \\
\hline Effingham & 2,362 & 2,447 & 2,643 & 3,947 & 3,631 & 3,911 & 3,771 & 4,837 & 4,784 & 4,739 & 4,680 \\
\hline Fayette & 1,748 & 1,785 & 1,849 & 2,291 & 2,374 & 2,457 & 2,415 & 2,748 & 2,848 & 3,052 & 2,923 \\
\hline Ford & 1,272 & 986 & 1,194 & 1,322 & 1,358 & 1,631 & 1,494 & 1,600 & 1,715 & 2,112 & 1,825 \\
\hline Franklin & 3,481 & 4,280 & 3,929 & 5,387 & 5,392 & 4,958 & 5,175 & 5,716 & 5,876 & 5,402 & 5,759 \\
\hline Fulton & 3,337 & 3,115 & 3,361 & 4,192 & 4,253 & 4,574 & 4,413 & 4,836 & 4,630 & 5,050 & 4,750 \\
\hline Gallatin & 576 & 695 & 663 & 772 & 707 & 675 & 691 & 802 & 762 & 669 & 723 \\
\hline Greene & 1,275 & 1,260 & 1,239 & 1,618 & 1,588 & 1,562 & 1,575 & 1,947 & 2,015 & 1,946 & 1,989 \\
\hline Grundy & 2,296 & 2,985 & 3,117 & 4,720 & 5,043 & 5,264 & 5,154 & 6,333 & 6,663 & 7,433 & 6,967 \\
\hline Hamilton & 800 & 848 & 857 & 1,146 & 1,064 & 1,075 & 1,070 & 1,423 & 1,187 & 1,114 & 1,148 \\
\hline Hancock & 1,793 & 2,392 & 1,975 & 3,175 & 2,904 & 2,342 & 2,623 & 3,101 & 3,111 & 2,286 & 2,831 \\
\hline Hardin & 474 & 517 & 526 & 686 & 676 & 687 & 681 & 711 & 645 & 646 & 643 \\
\hline Henderson & 757 & 792 & 852 & 960 & 945 & 1,011 & 978 & 1,187 & 1,084 & 1,141 & 1,094 \\
\hline Henry & 4,093 & 4,387 & 4,454 & 5,965 & 6,101 & 6,191 & 6,146 & 6,522 & 6,463 & 6,703 & 6,558 \\
\hline Iroquois & 2,737 & 2,926 & 2,866 & 3,768 & 3,658 & 3,585 & 3,622 & 4,247 & 4,222 & 4,018 & 4,140 \\
\hline Jackson & 3,308 & 3,917 & 3,560 & 5,857 & 5,868 & 5,329 & 5,599 & 5,338 & 6,082 & 5,532 & 5,948 \\
\hline Jasper & 793 & 874 & 844 & 1,574 & 1,194 & 1,153 & 1,174 & 1,810 & 1,848 & 1,351 & 1,610 \\
\hline Jefferson & 2,955 & 3,266 & 3,356 & 4,903 & 4,696 & 4,818 & 4,757 & 5,758 & 5,155 & 5,074 & 5,083 \\
\hline Jersey & 1,633 & 1,903 & 1,929 & 2,639 & 2,668 & 2,703 & 2,686 & 3,428 & 3,388 & 3,471 & 3,418 \\
\hline Jo Daviess & 2,144 & 2,784 & 2,707 & 3,681 & 3,723 & 3,617 & 3,670 & 4,115 & 3,691 & 3,625 & 3,686 \\
\hline
\end{tabular}


Appendix H, Continued: Total Population Age 65-74 for Illinois Counties, 2000 - 2030

\begin{tabular}{|c|c|c|c|c|c|c|c|c|c|c|c|}
\hline \multirow[b]{2}{*}{ County } & \multirow[b]{2}{*}{2000} & \multicolumn{2}{|c|}{2010} & \multicolumn{4}{|c|}{2020} & \multicolumn{4}{|c|}{2030} \\
\hline & & DCEO & CENSUS & DCEO & ALT E & ALT F & ALT G & DCEO & ALT E & ALT F & ALT G \\
\hline Johnson & 977 & 1,164 & 1,295 & 1,663 & 1,553 & 1,722 & 1,637 & 2,006 & 2,014 & 2,088 & 2,002 \\
\hline Kane & 17,900 & 25,635 & 28,108 & 45,775 & 48,022 & 52,585 & 50,303 & 58,736 & 62,239 & 71,667 & 65,319 \\
\hline Kankakee & 7,007 & 7,964 & 7,952 & 11,695 & 12,052 & 12,035 & 12,044 & 13,754 & 14,057 & 14,454 & 14,261 \\
\hline Kendall & 2,478 & 3,713 & 5,115 & 5,697 & 8,193 & 11,243 & 9,718 & 8,382 & 11,383 & 22,421 & 15,160 \\
\hline Knox & 4,728 & 4,788 & 4,864 & 6,633 & 6,441 & 6,540 & 6,490 & 6,466 & 6,531 & 6,445 & 6,464 \\
\hline Lake & 30,679 & 39,158 & 40,436 & 61,381 & 61,383 & 63,444 & 62,413 & 82,011 & 78,631 & 81,131 & 79,257 \\
\hline LaSalle & 8,827 & 8,822 & 9,202 & 12,403 & 12,856 & 13,388 & 13,122 & 15,550 & 15,408 & 16,627 & 15,847 \\
\hline Lawrence & 1,445 & 1,472 & 1,327 & 2,004 & 1,931 & 1,745 & 1,838 & 2,184 & 2,482 & 2,165 & 2,380 \\
\hline Lee & 2,703 & 2,608 & 2,932 & 4,171 & 4,103 & 4,582 & 4,342 & 5,431 & 5,026 & 5,518 & 5,130 \\
\hline Livingston & 2,925 & 2,889 & 3,084 & 4,108 & 4,197 & 4,468 & 4,332 & 4,968 & 5,095 & 5,538 & 5,231 \\
\hline Logan & 2,227 & 2,220 & 2,349 & 2,714 & 3,064 & 3,233 & 3,149 & 3,370 & 3,294 & 3,894 & 3,541 \\
\hline $\begin{array}{l}\text { Mc- } \\
\text { Donough }\end{array}$ & 2,203 & 2,173 & 2,215 & 2,966 & 3,008 & 3,065 & 3,037 & 2,907 & 2,873 & 2,969 & 2,907 \\
\hline McHenry & 11,371 & 18,314 & 18,560 & 31,867 & 32,298 & 32,742 & 32,520 & 46,337 & 45,652 & 46,920 & 46,122 \\
\hline McLean & 7,535 & 8,832 & 9,015 & 15,335 & 15,343 & 15,651 & 15,497 & 19,417 & 18,995 & 19,390 & 19,096 \\
\hline Macon & 9,073 & 8,681 & 9,079 & 12,847 & 12,828 & 13,367 & 13,097 & 13,148 & 13,388 & 13,920 & 13,516 \\
\hline Macoupin & 4,134 & 4,242 & 4,055 & 6,473 & 6,008 & 5,749 & 5,879 & 7,328 & 7,238 & 6,437 & 6,909 \\
\hline Madison & 19,298 & 19,485 & 19,759 & 27,482 & 28,361 & 28,739 & 28,550 & 32,261 & 33,604 & 35,103 & 34,236 \\
\hline Marion & 3,271 & 3,700 & 3,593 & 4,758 & 4,776 & 4,642 & 4,709 & 5,243 & 5,228 & 5,100 & 5,201 \\
\hline Marshall & 1,184 & 1,223 & 1,249 & 1,636 & 1,685 & 1,720 & 1,702 & 1,907 & 1,692 & 1,778 & 1,726 \\
\hline Mason & 1,354 & 1,408 & 1,415 & 1,862 & 1,773 & 1,782 & 1,778 & 1,852 & 1,886 & 1,805 & 1,843 \\
\hline Massac & 1,303 & 1,606 & 1,461 & 1,939 & 1,850 & 1,677 & 1,764 & 2,430 & 2,239 & 1,932 & 2,135 \\
\hline Menard & 826 & 1,152 & 1,121 & 1,700 & 1,697 & 1,652 & 1,674 & 2,179 & 1,931 & 1,875 & 1,916 \\
\hline Mercer & 1,336 & 1,458 & 1,608 & 1,940 & 1,914 & 2,102 & 2,008 & 2,177 & 2,110 & 2,284 & 2,147 \\
\hline Monroe & 2,002 & 2,361 & 2,352 & 3,636 & 3,908 & 3,893 & 3,900 & 5,398 & 5,419 & 5,802 & 5,617 \\
\hline $\begin{array}{l}\text { Montgom- } \\
\text { ery }\end{array}$ & 2,465 & 2,427 & 2,488 & 3,414 & 3,478 & 3,563 & 3,521 & 4,103 & 4,152 & 4,333 & 4,216 \\
\hline Morgan & 2,792 & 3,175 & 3,050 & 4,329 & 4,233 & 4,069 & 4,151 & 4,955 & 4,730 & 4,446 & 4,633 \\
\hline Moultrie & 1,173 & 1,317 & 1,262 & 1,871 & 1,761 & 1,685 & 1,723 & 2,194 & 1,997 & 1,795 & 1,916 \\
\hline Ogle & 3,539 & 4,363 & 4,466 & 6,265 & 6,132 & 6,275 & 6,203 & 7,941 & 7,776 & 7,792 & 7,740 \\
\hline Peoria & 12,925 & 13,768 & 13,411 & 20,287 & 19,990 & 19,489 & 19,739 & 20,361 & 20,578 & 19,769 & 20,301 \\
\hline Perry & 1,804 & 1,955 & 1,840 & 2,746 & 2,585 & 2,436 & 2,511 & 3,062 & 3,008 & 2,673 & 2,880 \\
\hline Piatt & 1,291 & 1,539 & 1,478 & 2,059 & 2,066 & 1,985 & 2,026 & 2,306 & 2,469 & 2,380 & 2,449 \\
\hline Pike & 1,507 & 1,440 & 1,551 & 1,871 & 1,941 & 2,084 & 2,012 & 1,978 & 1,941 & 2,160 & 2,013 \\
\hline Pope & 417 & 399 & 564 & 487 & 507 & 709 & 608 & 606 & 527 & 762 & 590 \\
\hline Pulaski & 632 & 641 & 583 & 943 & 852 & 776 & 814 & 1,175 & 972 & 799 & 905 \\
\hline Putnam & 502 & 609 & 595 & 810 & 861 & 842 & 852 & 948 & 964 & 1,001 & 989 \\
\hline Randolph & 2,524 & 2,606 & 2,731 & 3,722 & 3,849 & 4,026 & 3,938 & 4,314 & 4,487 & 4,849 & 4,614 \\
\hline Richland & 1,425 & 1,696 & 1,541 & 2,271 & 2,080 & 1,894 & 1,987 & 2,576 & 2,803 & 2,343 & 2,629 \\
\hline Rock Island & 11,390 & 12,426 & 12,203 & 17,393 & 17,162 & 16,863 & 17,013 & 17,900 & 17,779 & 17,238 & 17,585 \\
\hline St. Clair & 17,879 & 16,274 & 17,252 & 24,817 & 25,997 & 27,482 & 26,739 & 28,430 & 31,301 & 34,625 & 32,486 \\
\hline Saline & 2,429 & 2,651 & 2,431 & 3,302 & 3,140 & 2,883 & 3,012 & 3,642 & 3,356 & 2,931 & 3,208 \\
\hline Sangamon & 12,939 & 14,595 & 14,307 & 23,506 & 23,659 & 23,216 & 23,437 & 27,049 & 26,462 & 26,125 & 26,419 \\
\hline Schuyler & 680 & 676 & 704 & 985 & 974 & 1,014 & 994 & 1,215 & 1,121 & 1,154 & 1,126 \\
\hline Scott & 453 & 532 & 526 & 670 & 609 & 602 & 605 & 762 & 818 & 735 & 779 \\
\hline Shelby & 2,046 & 2,194 & 2,187 & 2,934 & 2,910 & 2,900 & 2,905 & 3,467 & 3,360 & 3,322 & 3,344 \\
\hline
\end{tabular}


Appendix H, Continued: Total Population Age 65-74 for Illinois Counties, 2000 - 2030

\begin{tabular}{|c|c|c|c|c|c|c|c|c|c|c|c|}
\hline \multirow[b]{2}{*}{ County } & \multirow[b]{2}{*}{2000} & \multicolumn{2}{|c|}{2010} & \multicolumn{4}{|c|}{2020} & \multicolumn{4}{|c|}{2030} \\
\hline & & DCEO & CENSUS & DCEO & ALT E & ALT F & ALT G & DCEO & ALT E & ALT F & ALT G \\
\hline Stark & 554 & 598 & 610 & 725 & 793 & 809 & 801 & 703 & 745 & 830 & 783 \\
\hline $\begin{array}{l}\text { Stephen- } \\
\text { son }\end{array}$ & 3,942 & 4,212 & 4,471 & 5,642 & 5,838 & 6,180 & 6,009 & 6,374 & 6,588 & 7,204 & 6,795 \\
\hline Tazewell & 10,217 & 10,778 & 10,717 & 15,768 & 15,683 & 15,597 & 15,640 & 17,478 & 17,286 & 17,100 & 17,217 \\
\hline Union & 1,506 & 1,942 & 1,819 & 2,475 & 2,421 & 2,275 & 2,348 & 2,866 & 2,761 & 2,539 & 2,691 \\
\hline Vermilion & 6,894 & 7,193 & 6,952 & 9,096 & 9,713 & 9,405 & 9,559 & 9,699 & 10,231 & 10,547 & 10,476 \\
\hline Wabash & 1,083 & 967 & 1,030 & 1,357 & 1,398 & 1,484 & 1,441 & 1,576 & 1,429 & 1,561 & 1,472 \\
\hline Warren & 1,503 & 1,611 & 1,592 & 2,196 & 2,058 & 2,034 & 2,046 & 2,115 & 2,017 & 1,866 & 1,947 \\
\hline $\begin{array}{l}\text { Washing- } \\
\text { ton }\end{array}$ & 1,199 & 1,400 & 1,278 & 1,896 & 1,826 & 1,667 & 1,747 & 2,300 & 2,229 & 1,956 & 2,140 \\
\hline Wayne & 1,576 & 1,631 & 1,714 & 2,117 & 2,005 & 2,104 & 2,055 & 2,447 & 2,351 & 2,340 & 2,319 \\
\hline White & 1,488 & 1,742 & 1,502 & 2,211 & 2,028 & 1,748 & 1,888 & 2,504 & 2,434 & 1,922 & 2,253 \\
\hline Whiteside & 4,925 & 5,077 & 5,166 & 7,094 & 6,948 & 7,066 & 7,007 & 7,558 & 7,578 & 7,551 & 7,533 \\
\hline Will & 22,731 & 37,222 & 36,418 & 64,572 & 64,321 & 62,841 & 63,581 & 95,832 & 93,246 & 90,678 & 92,507 \\
\hline Williamson & 4,991 & 5,883 & 5,973 & 7,745 & 8,136 & 8,256 & 8,196 & 8,899 & 9,271 & 9,866 & 9,532 \\
\hline Winnebago & 18,368 & 21,105 & 21,498 & 31,456 & 31,716 & 32,293 & 32,005 & 35,891 & 36,474 & 37,441 & 36,789 \\
\hline Woodford & 2,415 & 2,727 & 2,835 & 4,309 & 4,330 & 4,496 & 4,413 & 4,804 & 4,981 & 5,199 & 5,041 \\
\hline
\end{tabular}


Appendix I: Total Population Age 75-84 for Illinois Counties, 2000 - 2030

\begin{tabular}{|c|c|c|c|c|c|c|c|c|c|c|c|}
\hline \multirow[b]{2}{*}{ County } & \multirow[b]{2}{*}{2000} & \multicolumn{2}{|c|}{2010} & \multicolumn{4}{|c|}{2020} & \multicolumn{4}{|c|}{2030} \\
\hline & & DCEO & CENSUS & DCEO & ALT E & ALT F & ALT G & DCEO & ALT E & ALT F & ALT G \\
\hline Total & 536,642 & 534,599 & 524,766 & 622,409 & 619,834 & 611,370 & 615,602 & 950,852 & 946,701 & 936,146 & 943,561 \\
\hline Adams & 4,519 & 3,937 & 4,074 & 4,254 & 4,262 & 4,400 & 4,331 & 5,628 & 5,697 & 5,895 & 5,749 \\
\hline Alexander & 563 & 537 & 471 & 571 & 531 & 470 & 500 & 829 & 755 & 626 & 709 \\
\hline Bond & 924 & 839 & 905 & 854 & 919 & 986 & 953 & 1,355 & 1,376 & 1,576 & 1,450 \\
\hline Boone & 1,536 & 1,547 & 1,908 & 2,313 & 2,577 & 3,141 & 2,859 & 3,496 & 3,947 & 5,289 & 4,382 \\
\hline Brown & 325 & 246 & 276 & 269 & 291 & 324 & 308 & 445 & 400 & 476 & 426 \\
\hline Bureau & 2,456 & 2,220 & 2,118 & 2,549 & 2,494 & 2,385 & 2,439 & 3,478 & 3,494 & 3,271 & 3,420 \\
\hline Calhoun & 329 & 369 & 328 & 412 & 431 & 386 & 409 & 508 & 517 & 484 & 515 \\
\hline Carroll & 1,132 & 1,107 & 1,073 & 1,149 & 1,223 & 1,188 & 1,205 & 1,596 & 1,686 & 1,740 & 1,726 \\
\hline Cass & 789 & 753 & 727 & 800 & 798 & 771 & 784 & 1,047 & 1,039 & 1,002 & 1,029 \\
\hline Champaign & 6,089 & 6,581 & 6,806 & 7,438 & 7,716 & 7,969 & 7,842 & 12,435 & 12,850 & 13,740 & 13,186 \\
\hline Christian & 2,192 & 2,015 & 2,042 & 2,138 & 2,116 & 2,144 & 2,130 & 2,795 & 2,789 & 2,795 & 2,783 \\
\hline Clark & 1,131 & 1,164 & 937 & 1,500 & 1,239 & 1,000 & 1,120 & 2,059 & 1,677 & 1,103 & 1,449 \\
\hline Clay & 1,046 & 876 & 853 & 956 & 882 & 860 & 871 & 1,290 & 1,280 & 1,154 & 1,224 \\
\hline Clinton & 1,766 & 1,987 & 1,956 & 2,230 & 2,028 & 1,997 & 2,012 & 3,124 & 3,124 & 2,790 & 2,967 \\
\hline Coles & 2,594 & 2,317 & 2,526 & 2,498 & 2,548 & 2,768 & 2,658 & 3,652 & 3,705 & 4,091 & 3,819 \\
\hline Cook & 225,517 & 212,533 & 204,431 & 229,793 & 222,961 & 214,974 & 218,968 & 348,851 & 338,430 & 317,933 & 330,918 \\
\hline Crawford & 1,194 & 1,252 & 1,149 & 1,353 & 1,259 & 1,159 & 1,209 & 1,821 & 1,801 & 1,547 & 1,705 \\
\hline Cumberland & 667 & 726 & 597 & 876 & 842 & 700 & 771 & 1,181 & 1,223 & 975 & 1,148 \\
\hline DeKalb & 3,230 & 3,083 & 3,366 & 3,517 & 4,049 & 4,405 & 4,227 & 5,482 & 6,212 & 7,721 & 6,803 \\
\hline De Witt & 1,012 & 1,066 & 867 & 1,261 & 1,266 & 1,035 & 1,150 & 1,650 & 1,586 & 1,300 & 1,516 \\
\hline Douglas & 1,153 & 1,160 & 1,112 & 1,190 & 1,156 & 1,109 & 1,132 & 1,554 & 1,576 & 1,470 & 1,538 \\
\hline DuPage & 31,676 & 33,385 & 32,885 & 45,243 & 44,582 & 43,951 & 44,267 & 73,643 & 73,609 & 71,580 & 72,849 \\
\hline Edgar & 1,297 & 1,205 & 1,142 & 1,348 & 1,383 & 1,314 & 1,349 & 1,806 & 1,884 & 1,837 & 1,885 \\
\hline Edwards & 505 & 509 & 415 & 603 & 484 & 394 & 439 & 808 & 795 & 520 & 682 \\
\hline Effingham & 1,692 & 1,590 & 1,758 & 1,701 & 1,837 & 2,025 & 1,931 & 2,861 & 2,632 & 3,113 & 2,800 \\
\hline Fayette & 1,239 & 1,209 & 1,241 & 1,285 & 1,331 & 1,365 & 1,348 & 1,707 & 1,769 & 1,875 & 1,811 \\
\hline Ford & 1,029 & 870 & 922 & 696 & 843 & 892 & 867 & 949 & 975 & 1,237 & 1,088 \\
\hline Franklin & 2,816 & 2,772 & 2,263 & 3,562 & 3,270 & 2,695 & 2,983 & 4,454 & 4,458 & 3,375 & 4,090 \\
\hline Fulton & 2,682 & 2,134 & 2,256 & 2,130 & 2,298 & 2,421 & 2,360 & 3,028 & 3,072 & 3,471 & 3,228 \\
\hline Gallatin & 420 & 397 & 360 & 510 & 487 & 444 & 465 & 585 & 536 & 468 & 513 \\
\hline Greene & 951 & 869 & 844 & 913 & 898 & 873 & 886 & 1,224 & 1,201 & 1,151 & 1,184 \\
\hline Grundy & 1,701 & 1,501 & 1,661 & 2,109 & 2,202 & 2,419 & 2,311 & 3,482 & 3,720 & 4,250 & 3,892 \\
\hline Hamilton & 615 & 537 & 539 & 601 & 607 & 610 & 608 & 850 & 789 & 800 & 794 \\
\hline Hancock & 1,361 & 1,304 & 1,272 & 1,754 & 1,448 & 1,413 & 1,431 & 2,373 & 2,170 & 1,708 & 1,949 \\
\hline Hardin & 311 & 372 & 275 & 437 & 445 & 337 & 391 & 571 & 562 & 431 & 532 \\
\hline Henderson & 454 & 551 & 492 & 615 & 662 & 595 & 628 & 761 & 749 & 722 & 756 \\
\hline Henry & 3,094 & 2,725 & 2,903 & 3,126 & 3,174 & 3,367 & 3,271 & 4,388 & 4,488 & 4,823 & 4,588 \\
\hline Iroquois & 2,132 & 1,885 & 1,854 & 2,117 & 2,074 & 2,041 & 2,057 & 2,791 & 2,710 & 2,615 & 2,672 \\
\hline Jackson & 2,328 & 2,476 & 2,352 & 3,024 & 2,748 & 2,615 & 2,682 & 4,507 & 4,516 & 3,901 & 4,256 \\
\hline Jasper & 634 & 640 & 559 & 723 & 698 & 612 & 655 & 1,291 & 979 & 828 & 933 \\
\hline Jefferson & 2,345 & 2,258 & 1,940 & 2,632 & 2,705 & 2,343 & 2,524 & 3,932 & 3,766 & 3,346 & 3,687 \\
\hline Jersey & 1,065 & 1,260 & 1,181 & 1,538 & 1,559 & 1,466 & 1,512 & 2,112 & 2,135 & 2,033 & 2,117 \\
\hline Jo Daviess & 1,403 & 1,535 & 1,493 & 2,062 & 2,005 & 1,952 & 1,978 & 2,768 & 2,799 & 2,649 & 2,742 \\
\hline Johnson & 591 & 506 & 653 & 739 & 822 & 1,017 & 920 & 1,140 & 1,065 & 1,439 & 1,184 \\
\hline
\end{tabular}


Appendix I, Continued: Total Population Age 75-84 for Illinois Counties, 2000 - 2030

\begin{tabular}{|c|c|c|c|c|c|c|c|c|c|c|c|}
\hline \multirow[b]{2}{*}{ County } & \multirow[b]{2}{*}{2000} & \multicolumn{2}{|c|}{2010} & \multicolumn{4}{|c|}{2020} & \multicolumn{4}{|c|}{2030} \\
\hline & & DCEO & CENSUS & DCEO & ALT E & ALT F & ALT G & DCEO & ALT E & ALT F & ALT G \\
\hline Kane & 11,758 & 13,698 & 15,066 & 19,788 & 21,697 & 23,845 & 22,771 & 34,647 & 36,347 & 43,820 & 39,036 \\
\hline Kankakee & 5,044 & 5,063 & 5,029 & 6,097 & 6,088 & 6,049 & 6,069 & 9,096 & 9,374 & 9,302 & 9,352 \\
\hline Kendall & 1,628 & 1,995 & 2,324 & 2,944 & 4,056 & 4,735 & 4,395 & 4,443 & 6,390 & 10,261 & 7,901 \\
\hline Knox & 3,585 & 3,223 & 3,347 & 3,460 & 3,515 & 3,642 & 3,579 & 4,953 & 4,810 & 5,055 & 4,889 \\
\hline Lake & 18,355 & 22,172 & 22,762 & 28,756 & 29,695 & 30,472 & 30,083 & 46,515 & 46,516 & 49,298 & 47,597 \\
\hline LaSalle & 6,869 & 6,213 & 6,324 & 6,592 & 6,876 & 6,992 & 6,934 & 9,418 & 9,762 & 10,335 & 10,005 \\
\hline Lawrence & 1,102 & 1,102 & 960 & 1,181 & 1,065 & 934 & 999 & 1,637 & 1,577 & 1,254 & 1,456 \\
\hline Lee & 1,865 & 1,797 & 1,889 & 1,826 & 2,053 & 2,153 & 2,103 & 3,043 & 2,993 & 3,499 & 3,205 \\
\hline Livingston & 2,174 & 1,907 & 2,074 & 2,035 & 2,172 & 2,348 & 2,260 & 2,987 & 3,051 & 3,504 & 3,212 \\
\hline Logan & 1,761 & 1,573 & 1,592 & 1,643 & 1,738 & 1,759 & 1,748 & 2,030 & 2,292 & 2,446 & 2,362 \\
\hline McDonough & 1,732 & 1,539 & 1,542 & 1,574 & 1,604 & 1,607 & 1,606 & 2,199 & 2,230 & 2,276 & 2,252 \\
\hline McHenry & 7,127 & 8,922 & 9,180 & 14,324 & 14,516 & 14,938 & 14,727 & 24,512 & 24,843 & 25,928 & 25,199 \\
\hline McLean & 5,138 & 5,443 & 5,666 & 6,621 & 6,758 & 7,025 & 6,892 & 11,643 & 11,649 & 12,347 & 11,881 \\
\hline Macon & 6,275 & 6,160 & 6,222 & 6,312 & 6,601 & 6,663 & 6,632 & 9,674 & 9,660 & 10,157 & 9,885 \\
\hline Macoupin & 3,094 & 2,956 & 2,817 & 3,229 & 3,087 & 2,950 & 3,018 & 4,963 & 4,607 & 4,215 & 4,458 \\
\hline Madison & 13,110 & 13,639 & 13,228 & 14,515 & 14,719 & 14,298 & 14,509 & 20,893 & 21,561 & 21,237 & 21,553 \\
\hline Marion & 2,554 & 2,525 & 2,163 & 3,003 & 2,916 & 2,519 & 2,717 & 3,908 & 3,923 & 3,299 & 3,738 \\
\hline Marshall & 904 & 803 & 834 & 880 & 899 & 931 & 915 & 1,222 & 1,258 & 1,329 & 1,283 \\
\hline Mason & 1,031 & 870 & 947 & 941 & 946 & 1,026 & 986 & 1,279 & 1,218 & 1,325 & 1,246 \\
\hline Massac & 995 & 1,015 & 913 & 1,253 & 1,140 & 1,026 & 1,083 & 1,548 & 1,477 & 1,207 & 1,373 \\
\hline Menard & 563 & 623 & 599 & 882 & 858 & 826 & 842 & 1,317 & 1,315 & 1,232 & 1,285 \\
\hline Mercer & 999 & 918 & 921 & 1,055 & 1,164 & 1,167 & 1,165 & 1,438 & 1,418 & 1,563 & 1,489 \\
\hline Monroe & 1,214 & 1,495 & 1,657 & 1,826 & 1,819 & 2,009 & 1,914 & 2,819 & 3,030 & 3,333 & 3,103 \\
\hline Montgomery & 1,932 & 1,821 & 1,786 & 1,895 & 1,943 & 1,907 & 1,925 & 2,691 & 2,741 & 2,758 & 2,762 \\
\hline Morgan & 2,073 & 1,821 & 1,963 & 2,197 & 2,111 & 2,266 & 2,188 & 3,150 & 3,080 & 3,168 & 3,073 \\
\hline Moultrie & 904 & 1,107 & 846 & 1,202 & 1,152 & 871 & 1,011 & 1,640 & 1,543 & 1,102 & 1,414 \\
\hline Ogle & 2,441 & 2,648 & 2,571 & 3,379 & 3,459 & 3,362 & 3,410 & 4,897 & 4,793 & 4,768 & 4,815 \\
\hline Peoria & 9,531 & 8,836 & 8,568 & 9,867 & 9,611 & 9,333 & 9,472 & 14,926 & 14,707 & 13,935 & 14,421 \\
\hline Perry & 1,361 & 1,210 & 1,155 & 1,465 & 1,379 & 1,323 & 1,351 & 2,159 & 2,032 & 1,841 & 1,955 \\
\hline Piatt & 918 & 726 & 860 & 933 & 896 & 1,049 & 973 & 1,358 & 1,363 & 1,515 & 1,388 \\
\hline Pike & 1,279 & 1,028 & 1,009 & 1,031 & 1,110 & 1,091 & 1,101 & 1,381 & 1,432 & 1,512 & 1,479 \\
\hline Pope & 254 & 207 & 306 & 189 & 267 & 401 & 334 & 257 & 268 & 542 & 357 \\
\hline Pulaski & 468 & 436 & 396 & 481 & 437 & 401 & 419 & 733 & 662 & 554 & 620 \\
\hline Putnam & 349 & 336 & 333 & 437 & 427 & 423 & 425 & 602 & 640 & 621 & 632 \\
\hline Randolph & 1,943 & 1,697 & 1,781 & 1,873 & 1,963 & 2,054 & 2,008 & 2,768 & 2,863 & 3,128 & 2,961 \\
\hline Richland & 981 & 1,001 & 1,024 & 1,255 & 1,140 & 1,165 & 1,153 & 1,721 & 1,576 & 1,466 & 1,514 \\
\hline Rock Island & 8,195 & 7,953 & 7,976 & 9,074 & 8,911 & 8,936 & 8,923 & 12,961 & 12,789 & 12,600 & 12,686 \\
\hline St. Clair & 11,710 & 12,191 & 11,852 & 11,593 & 12,290 & 11,963 & 12,126 & 18,229 & 19,096 & 19,666 & 19,514 \\
\hline Saline & 1,848 & 1,818 & 1,531 & 2,070 & 1,898 & 1,611 & 1,755 & 2,617 & 2,489 & 1,944 & 2,298 \\
\hline Sangamon & 9,148 & 9,379 & 9,000 & 11,308 & 11,085 & 10,666 & 10,875 & 18,313 & 18,432 & 17,407 & 18,088 \\
\hline Schuyler & 504 & 567 & 470 & 581 & 605 & 505 & 555 & 839 & 830 & 719 & 811 \\
\hline Scott & 321 & 325 & 310 & 402 & 397 & 380 & 389 & 511 & 464 & 439 & 457 \\
\hline Shelby & 1,498 & 1,511 & 1,376 & 1,690 & 1,685 & 1,540 & 1,612 & 2,288 & 2,269 & 2,070 & 2,217 \\
\hline Stark & 462 & 363 & 384 & 409 & 417 & 440 & 429 & 528 & 578 & 620 & 591 \\
\hline Stephenson & 2,907 & 2,927 & 3,016 & 3,415 & 3,625 & 3,726 & 3,675 & 4,714 & 4,878 & 5,303 & 5,054 \\
\hline
\end{tabular}


Appendix I, Continued: Total Population Age 75-84 for Illinois Counties, 2000 - 2030

\begin{tabular}{|l|r|rr|rrrr|rrr|r|}
\hline & & \multicolumn{2}{|c|}{$\mathbf{2 0 1 0}$} & \multicolumn{9}{c|}{$\mathbf{2 0 2 0}$} & \multicolumn{3}{c|}{2030} \\
County & $\mathbf{2 0 0 0}$ & DCEO & CENSUS & DCEO & ALT E & ALT F & ALT G & DCEO & ALT E & ALT F & ALT G \\
\hline Tazewell & 6,433 & 7,793 & 7,400 & 8,604 & 8,555 & 8,143 & 8,349 & 12,472 & 12,405 & 11,737 & 12,220 \\
Union & 1,216 & 1,300 & 973 & 1,748 & 1,637 & 1,242 & 1,440 & 2,226 & 2,178 & 1,552 & 1,984 \\
Vermilion & 4,944 & 4,760 & 4,468 & 5,302 & 5,124 & 4,830 & 4,977 & 6,949 & 7,420 & 6,786 & 7,201 \\
Wabash & 788 & 777 & 743 & 753 & 802 & 770 & 786 & 1,081 & 1,114 & 1,135 & 1,137 \\
Warren & 1,110 & 961 & 985 & 1,055 & 1,043 & 1,068 & 1,055 & 1,496 & 1,402 & 1,418 & 1,402 \\
Washington & 988 & 841 & 828 & 1,016 & 927 & 914 & 921 & 1,413 & 1,361 & 1,224 & 1,297 \\
Wayne & 1,178 & 989 & 1,092 & 1,085 & 1,140 & 1,252 & 1,196 & 1,499 & 1,420 & 1,627 & 1,488 \\
White & 1,171 & 1,106 & 1,062 & 1,343 & 1,158 & 1,114 & 1,136 & 1,732 & 1,589 & 1,317 & 1,465 \\
Whiteside & 3,528 & 3,526 & 3,472 & 3,805 & 3,872 & 3,815 & 3,843 & 5,445 & 5,333 & 5,346 & 5,359 \\
Will & 14,334 & 19,205 & 18,894 & 29,948 & 29,301 & 28,803 & 29,052 & 50,947 & 50,749 & 48,721 & 49,948 \\
Williamson & 3,796 & 3,970 & 3,408 & 4,982 & 5,058 & 4,386 & 4,722 & 6,575 & 6,907 & 6,079 & 6,727 \\
Winnebago & 12,812 & 12,946 & 13,243 & 15,543 & 15,832 & 16,180 & 16,006 & 23,681 & 23,877 & 24,833 & 24,223 \\
Woodford & 1,935 & 2,061 & 1,847 & 2,353 & 2,446 & 2,195 & 2,321 & 3,562 & 3,579 & 3,318 & 3,550 \\
\hline
\end{tabular}


Appendix J: Total Population Age 85 and Older for Illinois Counties, 2000 - 2030

\begin{tabular}{|c|c|c|c|c|c|c|c|c|c|c|c|}
\hline \multirow[b]{2}{*}{ County } & \multirow[b]{2}{*}{2000} & \multicolumn{2}{|c|}{2010} & \multicolumn{4}{|c|}{2020} & \multicolumn{4}{|c|}{2030} \\
\hline & & DCEO & CENSUS & DCEO & ALT E & ALT F & ALT G & DCEO & ALT E & ALT F & ALT G \\
\hline Total & 192,346 & 269,950 & 234,912 & 314,336 & 308,534 & 274,563 & 291,549 & 402,311 & 400,669 & 355,653 & 387,778 \\
\hline Adams & 1,919 & 2,277 & 2,023 & 2,412 & 2,496 & 2,267 & 2,381 & 2,555 & 2,560 & 2,395 & 2,540 \\
\hline Alexander & 234 & 298 & 164 & 336 & 295 & 183 & 239 & 400 & 372 & 217 & 321 \\
\hline Bond & 357 & 300 & 421 & 308 & 332 & 451 & 391 & 348 & 374 & 531 & 419 \\
\hline Boone & 512 & 901 & 668 & 1,046 & 1,290 & 1,001 & 1,145 & 1,564 & 1,742 & 1,648 & 1,825 \\
\hline Brown & 142 & 112 & 126 & 100 & 112 & 124 & 118 & 115 & 125 & 153 & 135 \\
\hline Bureau & 930 & 1,240 & 1,074 & 1,312 & 1,252 & 1,109 & 1,180 & 1,592 & 1,558 & 1,328 & 1,482 \\
\hline Calhoun & 138 & 110 & 135 & 126 & 112 & 137 & 124 & 151 & 158 & 171 & 158 \\
\hline Carroll & 418 & 699 & 477 & 883 & 856 & 645 & 751 & 1,064 & 1,132 & 867 & 1,057 \\
\hline Cass & 308 & 421 & 322 & 461 & 445 & 354 & 399 & 524 & 523 & 408 & 489 \\
\hline Champaign & 2,282 & 3,573 & 2,980 & 4,345 & 4,494 & 3,831 & 4,162 & 5,275 & 5,472 & 4,876 & 5,371 \\
\hline Christian & 974 & 1,120 & 1,005 & 1,081 & 1,095 & 988 & 1,042 & 1,179 & 1,167 & 1,070 & 1,147 \\
\hline Clark & 469 & 620 & 467 & 694 & 559 & 432 & 495 & 936 & 773 & 489 & 661 \\
\hline Clay & 476 & 444 & 391 & 409 & 398 & 355 & 377 & 493 & 455 & 400 & 438 \\
\hline Clinton & 638 & 868 & 776 & 1,009 & 993 & 891 & 942 & 1,244 & 1,131 & 1,010 & 1,096 \\
\hline Coles & 968 & 1,312 & 1,198 & 1,371 & 1,495 & 1,384 & 1,439 & 1,575 & 1,607 & 1,624 & 1,647 \\
\hline Cook & 76,657 & 101,928 & 91,377 & 113,867 & 109,526 & 99,962 & 104,744 & 141,694 & 137,481 & 122,499 & 132,458 \\
\hline Crawford & 466 & 615 & 491 & 726 & 666 & 547 & 607 & 855 & 795 & 612 & 732 \\
\hline Cumberland & 253 & 345 & 290 & 423 & 348 & 299 & 323 & 560 & 538 & 390 & 477 \\
\hline DeKalb & 1,205 & 1,625 & 1,576 & 1,772 & 1,935 & 1,884 & 1,909 & 2,158 & 2,485 & 2,636 & 2,578 \\
\hline De Witt & 359 & 534 & 389 & 628 & 511 & 387 & 449 & 805 & 808 & 512 & 693 \\
\hline Douglas & 412 & 709 & 465 & 798 & 765 & 530 & 647 & 867 & 842 & 573 & 765 \\
\hline DuPage & 11,635 & 18,855 & 15,873 & 23,386 & 23,036 & 19,940 & 21,488 & 32,388 & 31,915 & 27,325 & 30,647 \\
\hline Edgar & 565 & 671 & 522 & 703 & 666 & 535 & 601 & 830 & 852 & 658 & 792 \\
\hline Edwards & 160 & 235 & 180 & 279 & 227 & 182 & 205 & 350 & 281 & 186 & 243 \\
\hline Effingham & 721 & 1,376 & 795 & 1,491 & 1,649 & 1,045 & 1,347 & 1,623 & 1,753 & 1,237 & 1,677 \\
\hline Fayette & 484 & 644 & 490 & 739 & 759 & 604 & 681 & 859 & 890 & 743 & 859 \\
\hline Ford & 469 & 486 & 517 & 454 & 481 & 509 & 495 & 405 & 490 & 546 & 511 \\
\hline Franklin & 1,007 & 1,711 & 1,086 & 2,032 & 1,659 & 1,157 & 1,408 & 2,650 & 2,433 & 1,407 & 2,053 \\
\hline Fulton & 1,009 & 898 & 1,075 & 806 & 852 & 1,001 & 927 & 977 & 1,054 & 1,270 & 1,121 \\
\hline Gallatin & 178 & 294 & 122 & 348 & 316 & 168 & 242 & 492 & 469 & 246 & 401 \\
\hline Greene & 362 & 657 & 305 & 790 & 767 & 455 & 611 & 969 & 953 & 604 & 858 \\
\hline Grundy & 618 & 815 & 768 & 834 & 923 & 877 & 900 & 1,210 & 1,264 & 1,321 & 1,310 \\
\hline Hamilton & 240 & 307 & 275 & 322 & 323 & 295 & 309 & 387 & 391 & 361 & 384 \\
\hline Hancock & 529 & 568 & 539 & 554 & 540 & 513 & 527 & 823 & 680 & 633 & 664 \\
\hline Hardin & 108 & 165 & 77 & 224 & 166 & 88 & 127 & 288 & 293 & 127 & 230 \\
\hline Henderson & 162 & 240 & 188 & 333 & 297 & 241 & 269 & 415 & 446 & 333 & 406 \\
\hline Henry & 1,170 & 1,214 & 1,267 & 1,256 & 1,338 & 1,388 & 1,363 & 1,661 & 1,686 & 1,847 & 1,752 \\
\hline Iroquois & 812 & 1,257 & 907 & 1,378 & 1,355 & 1,051 & 1,203 & 1,639 & 1,605 & 1,245 & 1,508 \\
\hline Jackson & 948 & 1,154 & 1,090 & 1,369 & 1,300 & 1,236 & 1,268 & 1,806 & 1,641 & 1,490 & 1,583 \\
\hline Jasper & 240 & 255 & 286 & 289 & 252 & 280 & 266 & 374 & 361 & 346 & 347 \\
\hline Jefferson & 839 & 1,275 & 992 & 1,530 & 1,315 & 1,080 & 1,197 & 1,924 & 1,977 & 1,430 & 1,769 \\
\hline Jersey & 422 & 662 & 495 & 896 & 840 & 655 & 747 & 1,126 & 1,141 & 843 & 1,048 \\
\hline Jo Daviess & 459 & 725 & 632 & 885 & 861 & 762 & 811 & 1,259 & 1,224 & 1,062 & 1,175 \\
\hline Johnson & 178 & 201 & 219 & 200 & 258 & 278 & 268 & 340 & 378 & 499 & 430 \\
\hline
\end{tabular}


Appendix J, Continued: Total Population Age 85 and Older for Illinois Counties, 2000 - 2030

\begin{tabular}{|c|c|c|c|c|c|c|c|c|c|c|c|}
\hline \multirow[b]{2}{*}{ County } & \multirow[b]{2}{*}{2000} & \multicolumn{2}{|c|}{2010} & \multicolumn{4}{|c|}{2020} & \multicolumn{4}{|c|}{2030} \\
\hline & & DCEO & CENSUS & DCEO & ALT E & ALT F & ALT G & DCEO & ALT E & ALT F & ALT G \\
\hline Kane & 4,380 & 7,285 & 6,516 & 9,136 & 10,048 & 9,063 & 9,556 & 12,732 & 13,960 & 13,783 & 14,279 \\
\hline Kankakee & 1,555 & 2,977 & 2,256 & 3,616 & 3,592 & 2,873 & 3,232 & 4,672 & 4,665 & 3,771 & 4,433 \\
\hline Kendall & 537 & 741 & 943 & 950 & 1,107 & 1,395 & 1,251 & 1,464 & 2,017 & 2,942 & 2,322 \\
\hline Knox & 1,484 & 2,058 & 1,551 & 2,340 & 2,430 & 1,957 & 2,193 & 2,797 & 2,841 & 2,429 & 2,766 \\
\hline Lake & 6,051 & 10,564 & 9,895 & 13,484 & 13,843 & 13,013 & 13,428 & 19,017 & 19,638 & 19,041 & 19,621 \\
\hline LaSalle & 2,628 & 3,388 & 3,152 & 3,573 & 3,637 & 3,420 & 3,528 & 4,104 & 4,281 & 4,113 & 4,257 \\
\hline Lawrence & 572 & 672 & 396 & 759 & 661 & 421 & 541 & 894 & 806 & 473 & 694 \\
\hline Lee & 729 & 747 & 823 & 817 & 859 & 936 & 897 & 959 & 1,078 & 1,218 & 1,126 \\
\hline Livingston & 969 & 1,217 & 984 & 1,274 & 1,386 & 1,163 & 1,274 & 1,476 & 1,576 & 1,452 & 1,579 \\
\hline Logan & 711 & 1,031 & 819 & 1,143 & 1,157 & 965 & 1,061 & 1,312 & 1,388 & 1,193 & 1,344 \\
\hline McDonough & 725 & 1,114 & 887 & 1,208 & 1,210 & 1,008 & 1,109 & 1,335 & 1,361 & 1,153 & 1,309 \\
\hline McHenry & 2,451 & 3,176 & 3,580 & 4,432 & 4,560 & 5,081 & 4,820 & 7,215 & 7,312 & 8,371 & 7,627 \\
\hline McLean & 1,974 & 3,078 & 2,659 & 3,718 & 3,870 & 3,408 & 3,639 & 4,770 & 4,869 & 4,488 & 4,824 \\
\hline Macon & 2,163 & 3,228 & 2,841 & 3,869 & 3,908 & 3,524 & 3,716 & 4,582 & 4,792 & 4,426 & 4,712 \\
\hline Macoupin & 1,364 & 1,675 & 1,299 & 1,845 & 1,758 & 1,416 & 1,587 & 2,162 & 2,067 & 1,617 & 1,929 \\
\hline Madison & 4,577 & 6,163 & 5,441 & 7,420 & 7,196 & 6,468 & 6,832 & 8,855 & 8,980 & 7,935 & 8,651 \\
\hline Marion & 1,112 & 2,689 & 1,167 & 3,445 & 2,951 & 1,662 & 2,307 & 4,276 & 4,152 & 2,085 & 3,464 \\
\hline Marshall & 389 & 396 & 385 & 401 & 416 & 406 & 411 & 476 & 486 & 492 & 492 \\
\hline Mason & 392 & 329 & 443 & 292 & 318 & 423 & 370 & 346 & 348 & 491 & 390 \\
\hline Massac & 406 & 818 & 464 & 843 & 758 & 433 & 596 & 1,094 & 995 & 531 & 849 \\
\hline Menard & 256 & 198 & 258 & 245 & 236 & 299 & 267 & 371 & 361 & 435 & 377 \\
\hline Mercer & 372 & 581 & 472 & 635 & 637 & 537 & 587 & 776 & 856 & 731 & 825 \\
\hline Monroe & 492 & 885 & 649 & 1,174 & 1,301 & 979 & 1,140 & 1,450 & 1,444 & 1,205 & 1,427 \\
\hline Montgomery & 827 & 1,076 & 925 & 1,181 & 1,158 & 1,019 & 1,089 & 1,355 & 1,389 & 1,215 & 1,339 \\
\hline Morgan & 851 & 804 & 922 & 780 & 841 & 953 & 897 & 1,086 & 1,043 & 1,249 & 1,113 \\
\hline Moultrie & 451 & 403 & 510 & 493 & 377 & 477 & 427 & 609 & 584 & 544 & 542 \\
\hline Ogle & 887 & 1,222 & 1,085 & 1,496 & 1,452 & 1,308 & 1,380 & 2,054 & 2,102 & 1,855 & 2,025 \\
\hline Peoria & 3,571 & 3,971 & 3,984 & 4,324 & 4,193 & 4,205 & 4,199 & 5,675 & 5,528 & 5,381 & 5,451 \\
\hline Perry & 533 & 504 & 520 & 594 & 567 & 581 & 574 & 873 & 822 & 804 & 809 \\
\hline Piatt & 325 & 341 & 375 & 281 & 333 & 365 & 349 & 415 & 399 & 506 & 442 \\
\hline Pike & 568 & 604 & 576 & 571 & 560 & 538 & 549 & 611 & 658 & 623 & 646 \\
\hline Pope & 111 & 48 & 95 & 38 & 56 & 113 & 84 & 37 & 52 & 153 & 81 \\
\hline Pulaski & 182 & 273 & 145 & 297 & 270 & 161 & 216 & 355 & 323 & 186 & 281 \\
\hline Putnam & 116 & 136 & 141 & 146 & 145 & 149 & 147 & 225 & 220 & 224 & 220 \\
\hline Randolph & 834 & 1,757 & 828 & 2,138 & 2,244 & 1,392 & 1,818 & 2,614 & 2,739 & 1,884 & 2,563 \\
\hline Richland & 442 & 638 & 545 & 784 & 802 & 705 & 753 & 1,024 & 930 & 840 & 913 \\
\hline Rock Island & 3,016 & 3,954 & 3,702 & 4,525 & 4,538 & 4,293 & 4,415 & 5,672 & 5,570 & 5,311 & 5,509 \\
\hline St. Clair & 4,177 & 5,553 & 4,706 & 6,720 & 6,533 & 5,676 & 6,104 & 7,173 & 7,604 & 6,536 & 7,284 \\
\hline Saline & 797 & 866 & 623 & 974 & 820 & 619 & 720 & 1,238 & 1,135 & 752 & 992 \\
\hline Sangamon & 3,481 & 4,689 & 4,055 & 5,636 & 5,408 & 4,785 & 5,096 & 7,333 & 7,188 & 6,177 & 6,864 \\
\hline Schuyler & 205 & 339 & 224 & 416 & 345 & 238 & 291 & 496 & 517 & 316 & 442 \\
\hline Scott & 141 & 189 & 130 & 209 & 199 & 142 & 171 & 272 & 269 & 187 & 245 \\
\hline Shelby & 541 & 658 & 669 & 775 & 706 & 716 & 711 & 973 & 970 & 898 & 931 \\
\hline Stark & 199 & 250 & 200 & 243 & 257 & 215 & 236 & 289 & 295 & 263 & 291 \\
\hline Stephenson & 1,192 & 1,909 & 1,471 & 2,468 & 2,543 & 2,089 & 2,316 & 3,278 & 3,480 & 3,015 & 3,390 \\
\hline
\end{tabular}


PLANNING TRANSPORTATION TO MEET THE NEEDS OF AN AGING ILLINOIS: AN ASSESSMENT

Appendix J, Continued: Total Population Age 85 and Older for Illinois Counties, 2000 - 2030

\begin{tabular}{|c|c|c|c|c|c|c|c|c|c|c|c|}
\hline \multirow[b]{2}{*}{ County } & \multirow[b]{2}{*}{2000} & \multicolumn{2}{|c|}{2010} & \multicolumn{4}{|c|}{2020} & \multicolumn{4}{|c|}{2030} \\
\hline & & DCEO & CENSUS & DCEO & ALT E & ALT F & ALT G & DCEO & ALT E & ALT F & ALT G \\
\hline Tazewell & 2,415 & 4,394 & 3,022 & 5,901 & 5,603 & 4,025 & 4,814 & 7,018 & 6,978 & 4,905 & 6,365 \\
\hline Union & 487 & 697 & 443 & 896 & 671 & 467 & 569 & 1,228 & 1,150 & 613 & 936 \\
\hline Vermilion & 1,609 & 2,250 & 1,882 & 2,596 & 2,437 & 2,104 & 2,270 & 3,238 & 3,130 & 2,590 & 2,947 \\
\hline Wabash & 328 & 362 & 359 & 414 & 396 & 393 & 394 & 458 & 488 & 465 & 477 \\
\hline Warren & 454 & 339 & 439 & 301 & 309 & 397 & 353 & 360 & 356 & 461 & 384 \\
\hline Washington & 354 & 387 & 397 & 347 & 342 & 350 & 346 & 469 & 428 & 431 & 427 \\
\hline Wayne & 471 & 405 & 453 & 370 & 409 & 453 & 431 & 492 & 517 & 619 & 555 \\
\hline White & 554 & 986 & 510 & 1,150 & 1,104 & 673 & 888 & 1,419 & 1,224 & 724 & 1,085 \\
\hline Whiteside & 1,305 & 1,919 & 1,609 & 2,235 & 2,201 & 1,896 & 2,048 & 2,664 & 2,711 & 2,336 & 2,606 \\
\hline Will & 4,617 & 8,462 & 7,502 & 11,702 & 11,513 & 10,247 & 10,880 & 18,593 & 18,191 & 15,953 & 17,550 \\
\hline Williamson & 1,354 & 1,972 & 1,456 & 2,393 & 2,054 & 1,591 & 1,823 & 3,160 & 3,208 & 2,186 & 2,835 \\
\hline Winnebago & 4,329 & 6,720 & 5,974 & 7,757 & 7,935 & 7,164 & 7,549 & 10,031 & 10,218 & 9,500 & 10,097 \\
\hline Woodford & 901 & 1,147 & 1,040 & 1,361 & 1,220 & 1,118 & 1,169 & 1,640 & 1,705 & 1,408 & 1,585 \\
\hline
\end{tabular}


Appendix K: Number \& Proportion of Older Adults by County

\begin{tabular}{|c|c|c|c|c|c|c|c|}
\hline \multirow[b]{2}{*}{ County } & \multirow[b]{2}{*}{$\begin{array}{r}\text { Total } \\
\text { Population }\end{array}$} & \multicolumn{2}{|c|}{$65+$} & \multicolumn{2}{|c|}{$75+$} & \multicolumn{2}{|c|}{$85+$} \\
\hline & & Number & Percent & Number & Percent & Number & Percen \\
\hline Adams & 67,098 & 11,809 & 17.6 & 6,173 & 9.2 & 2,080 & 3.1 \\
\hline Alexander & 8,147 & 1,409 & 17.3 & 635 & 7.8 & 163 & 2.0 \\
\hline Bond & 17,762 & 2,824 & 15.9 & 1,314 & 7.4 & 409 & 2.3 \\
\hline Boone & 54,141 & 6,334 & 11.7 & 2,599 & 4.8 & 541 & 1.0 \\
\hline Brown & 6,913 & 850 & 12.3 & 401 & 5.8 & 166 & 2.4 \\
\hline Bureau & 34,798 & 6,333 & 18.2 & 3,201 & 9.2 & 905 & 2.6 \\
\hline Calhoun & 5,065 & 1,028 & 20.3 & 466 & 9.2 & 137 & 2.7 \\
\hline Carroll & 15,338 & 3,282 & 21.4 & 1,534 & 10.0 & 414 & 2.7 \\
\hline Cass & 13,570 & 2,090 & 15.4 & 1,031 & 7.6 & 217 & 1.6 \\
\hline Champaign & 200,931 & 20,495 & 10.2 & 9,846 & 4.9 & 2,813 & 1.4 \\
\hline Christian & 34,805 & 6,160 & 17.7 & 3,063 & 8.8 & 905 & 2.6 \\
\hline Clark & 16,353 & 2,944 & 18.0 & 1,423 & 8.7 & 474 & 2.9 \\
\hline Clay & 13,828 & 2,489 & 18.0 & 1,258 & 9.1 & 332 & 2.4 \\
\hline Clinton & 37,793 & 5,669 & 15.0 & 2,834 & 7.5 & 794 & 2.1 \\
\hline Coles & 53,683 & 7,623 & 14.2 & 3,758 & 7.0 & 1,127 & 2.1 \\
\hline Cook & $5,197,677$ & 628,919 & 12.1 & 301,465 & 5.8 & 93,558 & 1.8 \\
\hline Crawford & 19,777 & 3,461 & 17.5 & 1,661 & 8.4 & 494 & 2.5 \\
\hline Cumberland & 11,044 & 1,844 & 16.7 & 906 & 8.2 & 287 & 2.6 \\
\hline De Witt & 16,562 & 2,849 & 17.2 & 1,292 & 7.8 & 348 & 2.1 \\
\hline DeKalb & 104,820 & 10,377 & 9.9 & 4,822 & 4.6 & 1,467 & 1.4 \\
\hline Douglas & 19,908 & 3,126 & 15.7 & 1,573 & 7.9 & 577 & 2.9 \\
\hline DuPage & 918,608 & 107,477 & 11.7 & 48,686 & 5.3 & 16,535 & 1.8 \\
\hline Edgar & 18,513 & 3,480 & 18.8 & 1,685 & 9.1 & 518 & 2.8 \\
\hline Edwards & 6,691 & 1,218 & 18.2 & 595 & 8.9 & 154 & 2.3 \\
\hline Effingham & 34,258 & 5,241 & 15.3 & 2,569 & 7.5 & 822 & 2.4 \\
\hline Fayette & 22,082 & 3,577 & 16.2 & 1,722 & 7.8 & 640 & 2.9 \\
\hline Ford & 14,045 & 2,669 & 19.0 & 1,447 & 10.3 & 534 & 3.8 \\
\hline Franklin & 39,518 & 7,311 & 18.5 & 3,359 & 8.5 & 869 & 2.2 \\
\hline Fulton & 36,989 & 6,658 & 18.0 & 3,292 & 8.9 & 925 & 2.5 \\
\hline Gallatin & 5,592 & 1,180 & 21.1 & 498 & 8.9 & 112 & 2.0 \\
\hline Greene & 13,828 & 2,434 & 17.6 & 1,162 & 8.4 & 373 & 2.7 \\
\hline Grundy & 49,870 & 5,585 & 11.2 & 2,394 & 4.8 & 748 & 1.5 \\
\hline Hamilton & 8,430 & 1,669 & 19.8 & 801 & 9.5 & 253 & 3.0 \\
\hline Hancock & 19,063 & 3,832 & 20.1 & 1,849 & 9.7 & 610 & 3.2 \\
\hline Hardin & 4,315 & 923 & 21.4 & 380 & 8.8 & 78 & 1.8 \\
\hline Henderson & 7,275 & 1,542 & 21.2 & 698 & 9.6 & 124 & 1.7 \\
\hline Henry & 50,378 & 8,615 & 17.1 & 4,131 & 8.2 & 1,159 & 2.3 \\
\hline Iroquois & 29,689 & 5,700 & 19.2 & 2,791 & 9.4 & 1,009 & 3.4 \\
\hline
\end{tabular}


Appendix K, Continued: Number \& Proportion of Older Adults by County

\begin{tabular}{|c|c|c|c|c|c|c|c|}
\hline \multirow[b]{2}{*}{ County } & \multirow[b]{2}{*}{$\begin{array}{r}\text { Total } \\
\text { Population } \\
\end{array}$} & \multicolumn{2}{|c|}{$65+$} & \multicolumn{2}{|c|}{$75+$} & \multicolumn{2}{|c|}{$85+$} \\
\hline & & Number & Percent & Number & Percent & Number & Percent \\
\hline Jackson & 59,992 & 6,959 & 11.6 & 3,420 & 5.7 & 1,140 & 1.9 \\
\hline Jasper & 9,707 & 1,660 & 17.1 & 835 & 8.6 & 204 & 2.1 \\
\hline Jefferson & 38,908 & 6,342 & 16.3 & 2,996 & 7.7 & 1,051 & 2.7 \\
\hline Jersey & 22,939 & 3,601 & 15.7 & 1,652 & 7.2 & 459 & 2.0 \\
\hline Jo Daviess & 22,663 & 4,873 & 21.5 & 2,153 & 9.5 & 521 & 2.3 \\
\hline Johnson & 12,653 & 2,151 & 17.0 & 848 & 6.7 & 228 & 1.8 \\
\hline Kane & 514,891 & 50,974 & 9.9 & 22,140 & 4.3 & 6,179 & 1.2 \\
\hline Kankakee & 113,170 & 15,278 & 13.5 & 7,243 & 6.4 & 2,263 & 2.0 \\
\hline Kendall & 114,226 & 8,110 & 7.1 & 3,084 & 2.7 & 685 & 0.6 \\
\hline Knox & 52,698 & 9,802 & 18.6 & 4,848 & 9.2 & 1,634 & 3.1 \\
\hline Lake & 701,282 & 72,933 & 10.4 & 32,259 & 4.6 & 9,818 & 1.4 \\
\hline LaSalle & 113,688 & 18,759 & 16.5 & 9,436 & 8.3 & 2,956 & 2.6 \\
\hline Lawrence & 16,778 & 2,684 & 16.0 & 1,342 & 8.0 & 386 & 2.3 \\
\hline Lee & 35,778 & 5,689 & 15.9 & 2,719 & 7.6 & 894 & 2.5 \\
\hline Livingston & 38,903 & 6,108 & 15.7 & 3,073 & 7.9 & 895 & 2.3 \\
\hline Logan & 30,278 & 4,814 & 15.9 & 2,422 & 8.0 & 878 & 2.9 \\
\hline Macon & 110,558 & 18,242 & 16.5 & 9,066 & 8.2 & 2,764 & 2.5 \\
\hline Macoupin & 47,712 & 8,159 & 17.1 & 4,056 & 8.5 & 1,241 & 2.6 \\
\hline Madison & 268,586 & 38,676 & 14.4 & 18,532 & 6.9 & 5,103 & 1.9 \\
\hline Marion & 39,319 & 6,842 & 17.4 & 3,342 & 8.5 & 1,140 & 2.9 \\
\hline Marshall & 12,567 & 2,513 & 20.0 & 1,257 & 10.0 & 427 & 3.4 \\
\hline Mason & 14,636 & 2,810 & 19.2 & 1,390 & 9.5 & 351 & 2.4 \\
\hline Massac & 15,370 & 2,828 & 18.4 & 1,353 & 8.8 & 384 & 2.5 \\
\hline McDonough & 32,568 & 4,625 & 14.2 & 2,410 & 7.4 & 651 & 2.0 \\
\hline McHenry & 308,163 & 31,741 & 10.3 & 12,943 & 4.2 & 3,698 & 1.2 \\
\hline McLean & 169,689 & 17,648 & 10.4 & 8,315 & 4.9 & 2,715 & 1.6 \\
\hline Menard & 12,728 & 2,036 & 16.0 & 878 & 6.9 & 267 & 2.1 \\
\hline Mercer & 16,421 & 3,005 & 18.3 & 1,396 & 8.5 & 427 & 2.6 \\
\hline Monroe & 33,003 & 4,686 & 14.2 & 2,277 & 6.9 & 858 & 2.6 \\
\hline Montgomery & 29,977 & 5,246 & 17.5 & 2,728 & 9.1 & 929 & 3.1 \\
\hline Morgan & 35,544 & 6,007 & 16.9 & 2,915 & 8.2 & 889 & 2.5 \\
\hline Moultrie & 14,844 & 2,672 & 18.0 & 1,395 & 9.4 & 445 & 3.0 \\
\hline Ogle & 53,378 & 8,167 & 15.3 & 3,683 & 6.9 & 1,014 & 1.9 \\
\hline Peoria & 186,399 & 25,909 & 13.9 & 12,489 & 6.7 & 3,914 & 2.1 \\
\hline Perry & 22,287 & 3,521 & 15.8 & 1,672 & 7.5 & 468 & 2.1 \\
\hline Piatt & 16,679 & 2,769 & 16.6 & 1,268 & 7.6 & 334 & 2.0 \\
\hline Pike & 16,436 & 3,106 & 18.9 & 1,561 & 9.5 & 592 & 3.6 \\
\hline Pope & 4,399 & 911 & 20.7 & 370 & 8.4 & 79 & 1.8 \\
\hline
\end{tabular}


Appendix K, Continued: Number \& Proportion of Older Adults by County

\begin{tabular}{|c|c|c|c|c|c|c|c|}
\hline \multirow[b]{2}{*}{ County } & \multirow[b]{2}{*}{$\begin{array}{r}\text { Total } \\
\text { Population }\end{array}$} & \multicolumn{2}{|c|}{$65+$} & \multicolumn{2}{|c|}{$75+$} & \multicolumn{2}{|c|}{$85+$} \\
\hline & & Number & Percent & Number & Percent & Number & Percent \\
\hline Pulaski & 6,107 & 1,111 & 18.2 & 513 & 8.4 & 159 & 2.6 \\
\hline Putnam & 5,968 & 1,056 & 17.7 & 460 & 7.7 & 143 & 2.4 \\
\hline Randolph & 33,353 & 5,403 & 16.2 & 2,635 & 7.9 & 867 & 2.6 \\
\hline Richland & 16,181 & 3,155 & 19.5 & 1,602 & 9.9 & 502 & 3.1 \\
\hline Rock Island & 147,504 & 24,043 & 16.3 & 11,800 & 8.0 & 3,835 & 2.6 \\
\hline Saline & 24,975 & 4,670 & 18.7 & 2,223 & 8.9 & 749 & 3.0 \\
\hline Sangamon & 197,474 & 27,449 & 13.9 & 13,033 & 6.6 & 4,344 & 2.2 \\
\hline Schuyler & 7,499 & 1,380 & 18.4 & 690 & 9.2 & 285 & 3.8 \\
\hline Scott & 5,322 & 953 & 17.9 & 452 & 8.5 & 160 & 3.0 \\
\hline Shelby & 22,316 & 4,285 & 19.2 & 2,053 & 9.2 & 580 & 2.6 \\
\hline St. Clair & 268,873 & 33,609 & 12.5 & 16,401 & 6.1 & 4,840 & 1.8 \\
\hline Stark & 5,983 & 1,232 & 20.6 & 604 & 10.1 & 221 & 3.7 \\
\hline Stephenson & 47,532 & 9,031 & 19.0 & 4,563 & 9.6 & 1,378 & 2.9 \\
\hline Tazewell & 135,201 & 21,091 & 15.6 & 10,410 & 7.7 & 2,974 & 2.2 \\
\hline Union & 17,799 & 3,257 & 18.3 & 1,424 & 8.0 & 427 & 2.4 \\
\hline Vermilion & 81,463 & 13,116 & 16.1 & 6,191 & 7.6 & 1,792 & 2.2 \\
\hline Wabash & 11,935 & 2,148 & 18.0 & 1,110 & 9.3 & 382 & 3.2 \\
\hline Warren & 17,723 & 2,960 & 16.7 & 1,436 & 8.1 & 514 & 2.9 \\
\hline Washington & 14,692 & 2,542 & 17.3 & 1,234 & 8.4 & 426 & 2.9 \\
\hline Wayne & 16,727 & 3,295 & 19.7 & 1,539 & 9.2 & 519 & 3.1 \\
\hline White & 14,686 & 3,055 & 20.8 & 1,557 & 10.6 & 426 & 2.9 \\
\hline Whiteside & 58,400 & 10,220 & 17.5 & 5,022 & 8.6 & 1,460 & 2.5 \\
\hline Will & 677,669 & 63,701 & 9.4 & 26,429 & 3.9 & 7,454 & 1.1 \\
\hline Williamson & 66,335 & 10,945 & 16.5 & 4,975 & 7.5 & 1,393 & 2.1 \\
\hline Winnebago & 294,433 & 40,926 & 13.9 & 19,138 & 6.5 & 6,183 & 2.1 \\
\hline Woodford & 38,736 & 5,733 & 14.8 & 2,905 & 7.5 & 1,046 & 2.7 \\
\hline
\end{tabular}


Appendix L: Number \& Proportion of Residents Age 65 \& Older Living Alone by County

\begin{tabular}{|lrr|}
\hline & $\begin{array}{r}\text { Living Alone } \\
\text { Numbed } 65+\end{array}$ \\
County & 3,427 & $46.4 \%$ \\
\hline Adams & 362 & $43.8 \%$ \\
Alexander & 908 & $50.8 \%$ \\
Bond & 1,212 & $33.1 \%$ \\
Boone & 245 & $44.1 \%$ \\
Brown & 1,989 & $47.1 \%$ \\
Bureau & 269 & $43.2 \%$ \\
Calhoun & 926 & $44.2 \%$ \\
Carroll & 574 & $44.1 \%$ \\
Cass & 6,144 & $46.4 \%$ \\
Champaign & 1,946 & $47.3 \%$ \\
Christian & 953 & $48.6 \%$ \\
Clark & 707 & $44.1 \%$ \\
Clay & 1,697 & $47.0 \%$ \\
Clinton & 2,500 & $52.1 \%$ \\
Coles & 190,211 & $47.9 \%$ \\
Cook & 1,153 & $51.4 \%$ \\
Crawford & 527 & $45.9 \%$ \\
Cumberland & 1,618 & $44.8 \%$ \\
De Witt & 868 & $47.7 \%$ \\
DeKalb & 3,246 & $49.9 \%$ \\
Douglas & 908 & $46.9 \%$ \\
DuPage & 27,560 & $42.8 \%$ \\
Edgar & 1,118 & $50.1 \%$ \\
Edwards & 415 & $51.6 \%$ \\
Effingham & 2,100 & $57.3 \%$ \\
Fayette & 999 & $46.0 \%$ \\
Ford & 876 & $52.4 \%$ \\
Franklin & 2,459 & $50.1 \%$ \\
Fulton & 1,801 & $43.7 \%$ \\
Gallatin & 356 & $47.2 \%$ \\
Greene & 801 & $48.2 \%$ \\
Grundy & 1,596 & $45.0 \%$ \\
Hamilton & 532 & $48.9 \%$ \\
Hancock & $43.0 \%$ \\
Hardin & $53.6 \%$ \\
Henderson & $42.1 \%$ \\
\hline
\end{tabular}

\begin{tabular}{|lrr|}
\hline & \multicolumn{2}{c}{ Living Alone Aged 65+ } \\
County & Number & Percent \\
\hline Jasper & 426 & $39.6 \%$ \\
Jefferson & 1,903 & $46.8 \%$ \\
Jersey & 915 & $40.5 \%$ \\
Jo Daviess & 1,160 & $38.0 \%$ \\
Johnson & 632 & $45.6 \%$ \\
Kane & 12,539 & $41.0 \%$ \\
Kankakee & 4,539 & $47.8 \%$ \\
Kendall & 1,859 & $37.0 \%$ \\
Knox & 3,524 & $53.6 \%$ \\
Lake & 18,864 & $41.8 \%$ \\
LaSalle & 5,592 & $46.3 \%$ \\
Lawrence & 922 & $52.3 \%$ \\
Lee & 1,641 & $47.0 \%$ \\
Livingston & 1,848 & $48.8 \%$ \\
Logan & 1,443 & $46.4 \%$ \\
Macon & 5,414 & $46.4 \%$ \\
Macoupin & 2,471 & $48.0 \%$ \\
Madison & 11,614 & $46.3 \%$ \\
Marion & 2,220 & $49.2 \%$ \\
Marshall & 746 & $48.4 \%$ \\
Mason & 927 & $49.7 \%$ \\
Massac & 968 & $56.9 \%$ \\
McDonough & 1,464 & $50.3 \%$ \\
McHenry & 7,579 & $39.9 \%$ \\
McLean & 5,196 & $46.4 \%$ \\
Menard & 601 & $48.3 \%$ \\
Mercer & 754 & $39.2 \%$ \\
Monroe & 1,160 & $40.2 \%$ \\
Montgomery & 1,712 & $50.0 \%$ \\
Morgan & 1,713 & $46.2 \%$ \\
Moultrie & 618 & $40.7 \%$ \\
Ogle & 2,245 & $43.2 \%$ \\
Peoria & 8,065 & $47.3 \%$ \\
Perry & 1,142 & $49.6 \%$ \\
Piatt & 793 & $45.2 \%$ \\
Pike & 450 & $37.6 \%$ \\
Pope & $57.2 \%$ \\
\hline
\end{tabular}

\begin{tabular}{|lrr|}
\hline County & $\begin{array}{r}\text { Living Alone Aged 65+ } \\
\text { Number }\end{array}$ & Percent \\
\hline Randolph & 1,748 & $50.8 \%$ \\
Richland & 939 & $47.2 \%$ \\
Rock Island & 8,196 & $50.7 \%$ \\
Saline & 1,379 & $46.5 \%$ \\
Sangamon & 9,055 & $50.4 \%$ \\
Schuyler & 367 & $41.8 \%$ \\
Scott & 305 & $52.4 \%$ \\
Shelby & 1,251 & $45.2 \%$ \\
St. Clair & 11,252 & $50.1 \%$ \\
Stark & 308 & $40.2 \%$ \\
Stephenson & 2,615 & $45.6 \%$ \\
Tazewell & 5,975 & $43.2 \%$ \\
Union & 943 & $46.2 \%$ \\
Vermilion & 4,593 & $51.0 \%$ \\
Wabash & 699 & $49.3 \%$ \\
Warren & 954 & $48.8 \%$ \\
Washington & 725 & $44.4 \%$ \\
Wayne & 1,009 & $46.6 \%$ \\
White & 849 & $44.1 \%$ \\
Whiteside & 2,899 & $43.2 \%$ \\
Will & 15,084 & $39.9 \%$ \\
Williamson & 3,323 & $47.5 \%$ \\
Winnebago & 11,675 & $45.4 \%$ \\
Woodford & 1,253 & $36.7 \%$ \\
\hline & & \\
\hline
\end{tabular}


Appendix M: Number \& Proportion of Residents with a Disability

\begin{tabular}{|c|c|c|c|}
\hline \multirow[b]{2}{*}{ County } & \multirow{2}{*}{$\begin{array}{r}\text { Total } \\
\text { Population }\end{array}$} & \multicolumn{2}{|c|}{ With a Disability } \\
\hline & & Number & Percent \\
\hline Adams & 65,736 & 9,122 & $13.9 \%$ \\
\hline Alexander & 7,736 & 1,752 & $22.6 \%$ \\
\hline Bond & 17,547 & 2,106 & $12.0 \%$ \\
\hline Boone & 53,825 & 4,525 & $8.4 \%$ \\
\hline Brown & 5,173 & 519 & $10.0 \%$ \\
\hline Bureau & 34,406 & 4,228 & $12.3 \%$ \\
\hline Calhoun & 4,993 & 839 & $16.8 \%$ \\
\hline Carroll & 15,096 & 2,120 & $14.0 \%$ \\
\hline Cass & 13,364 & 1,594 & $11.9 \%$ \\
\hline Champaign & 199,375 & 16,942 & $8.5 \%$ \\
\hline Christian & 33,067 & 4,513 & $13.6 \%$ \\
\hline Clark & 16,086 & 2,535 & $15.8 \%$ \\
\hline Clay & 13,608 & 1,970 & $14.5 \%$ \\
\hline Clinton & 35,709 & 3,999 & $11.2 \%$ \\
\hline Coles & 52,889 & 6,325 & $12.0 \%$ \\
\hline Cook & $5,155,227$ & 522,915 & $10.1 \%$ \\
\hline Crawford & 18,977 & 3,118 & $16.4 \%$ \\
\hline Cumberland & 10,852 & 1,789 & $16.5 \%$ \\
\hline De Witt & 16,192 & 2,204 & $13.6 \%$ \\
\hline DeKalb & 104,055 & 7,737 & $7.4 \%$ \\
\hline Douglas & 19,699 & 2,033 & $10.3 \%$ \\
\hline DuPage & 912,088 & 70,476 & $7.7 \%$ \\
\hline Edgar & 18,220 & 2,806 & $15.4 \%$ \\
\hline Edwards & 6,656 & 1,020 & $15.3 \%$ \\
\hline Effingham & 33,865 & 4,054 & $12.0 \%$ \\
\hline Fayette & 21,201 & 2,956 & $13.9 \%$ \\
\hline Ford & 13,621 & 1,722 & $12.6 \%$ \\
\hline Franklin & 39,015 & 7,742 & $19.8 \%$ \\
\hline Fulton & 34,714 & 4,918 & $14.2 \%$ \\
\hline Gallatin & 5,560 & 1,197 & $21.5 \%$ \\
\hline Greene & 13,521 & 2,136 & $15.8 \%$ \\
\hline Grundy & 49,582 & 4,613 & $9.3 \%$ \\
\hline Hamilton & 8,332 & 1,436 & $17.2 \%$ \\
\hline Hancock & 18,840 & 2,841 & $15.1 \%$ \\
\hline Hardin & 4,224 & 1,256 & $29.7 \%$ \\
\hline Henderson & 7,188 & 1,121 & $15.6 \%$ \\
\hline Henry & 49,646 & 5,400 & $10.9 \%$ \\
\hline Iroquois & 29,047 & 3,716 & $12.8 \%$ \\
\hline
\end{tabular}

\begin{tabular}{|l|r|rr|}
\hline & Total & \multicolumn{2}{|c|}{ With a Disability } \\
County & Population & Number & Percent \\
\hline Jackson & 59,121 & 6,484 & $11.0 \%$ \\
Jasper & 9,627 & 1,352 & $14.0 \%$ \\
Jefferson & 36,935 & 5,706 & $15.4 \%$ \\
Jersey & 22,578 & 2,300 & $10.2 \%$ \\
Jo Daviess & 22,494 & 2,851 & $12.7 \%$ \\
Johnson & 10,611 & 2,007 & $18.9 \%$ \\
Kane & 510,354 & 37,814 & $7.4 \%$ \\
Kankakee & 111,053 & 15,478 & $13.9 \%$ \\
Kendall & 113,720 & 7,276 & $6.4 \%$ \\
Knox & 49,938 & 7,133 & $14.3 \%$ \\
Lake & 685,169 & 51,558 & $7.5 \%$ \\
LaSalle & 111,603 & 12,981 & $11.6 \%$ \\
Lawrence & 10,957 & 1,732 & $15.8 \%$ \\
Lee & 33,771 & 4,056 & $12.0 \%$ \\
Livingston & 34,465 & 4,570 & $13.3 \%$ \\
Logan & 24,110 & 3,186 & $13.2 \%$ \\
Macon & 108,389 & 14,987 & $13.8 \%$ \\
Macoupin & 47,009 & 6,937 & $14.8 \%$ \\
Madison & 264,833 & 30,895 & $11.7 \%$ \\
Marion & 38,652 & 7,204 & $18.6 \%$ \\
Marshall & 12,287 & 1,562 & $12.7 \%$ \\
Mason & 14,460 & 2,228 & $15.4 \%$ \\
Massac & 15,155 & 2,826 & $18.6 \%$ \\
McDonough & 32,208 & 3,428 & $10.6 \%$ \\
McHenry & 306,873 & 23,425 & $7.6 \%$ \\
McLean & 168,408 & 14,914 & $8.9 \%$ \\
Menard & 12,517 & 1,521 & $12.2 \%$ \\
Mercer & 16,206 & 1,918 & $11.8 \%$ \\
Monroe & 32,733 & 3,154 & $9.6 \%$ \\
Montgomery & 25,153 & 3,432 & $13.6 \%$ \\
Morgan & 33,824 & 4,493 & $13.3 \%$ \\
Moultrie & 14,524 & 1,858 & $12.8 \%$ \\
Ogle & 52,768 & 5,385 & $10.2 \%$ \\
Peoria & 183,625 & 19,971 & $10.9 \%$ \\
Perry & & 3,219 & $16.0 \%$ \\
\hline & 1,992 & $12.0 \%$ \\
\hline
\end{tabular}


Appendix M, Continued: Number \& Proportion of Residents with a Disability

\begin{tabular}{|l|r|rr|}
\hline & Total & \multicolumn{2}{|c|}{ With a Disability } \\
County & Population & Number & Percent \\
\hline Pulaski & 5,967 & 1,200 & $20.1 \%$ \\
Putnam & 5,958 & 687 & $11.5 \%$ \\
Randolph & 30,044 & 4,493 & $15.0 \%$ \\
Richland & 16,012 & 2,653 & $16.6 \%$ \\
Rock Island & 145,079 & 18,043 & $12.4 \%$ \\
Saline & 24,201 & 4,851 & $20.0 \%$ \\
Sangamon & 195,205 & 25,384 & $13.0 \%$ \\
Schuyler & 7,413 & 1,056 & $14.2 \%$ \\
Scott & 5,273 & 622 & $11.8 \%$ \\
Shelby & 22,083 & 3,012 & $13.6 \%$ \\
St. Clair & 261,967 & 36,068 & $13.8 \%$ \\
Stark & 5,877 & 762 & $13.0 \%$ \\
Stephenson & 46,846 & 6,843 & $14.6 \%$ \\
Tazewell & 132,629 & 14,111 & $10.6 \%$ \\
Union & 17,442 & 2,947 & $16.9 \%$ \\
Vermilion & 79,939 & 12,076 & $15.1 \%$ \\
Wabash & 11,825 & 1,939 & $16.4 \%$ \\
Warren & 17,499 & 2,284 & $13.1 \%$ \\
Washington & 14,456 & 2,021 & $14.0 \%$ \\
Wayne & 16,586 & 2,563 & $15.5 \%$ \\
White & 14,342 & 2,443 & $17.0 \%$ \\
Whiteside & 57,539 & 8,011 & $13.9 \%$ \\
Will & 672,035 & 51,683 & $7.7 \%$ \\
Williamson & 64,386 & 10,105 & $15.7 \%$ \\
Winnebago & 34,7074 & $11.9 \%$ \\
Woodford & 3,195 & $8.4 \%$ \\
\hline
\end{tabular}


Appendix N: Proportion of Housing Types by County

\begin{tabular}{|c|c|c|c|c|}
\hline County & $\begin{array}{c}\text { Total } \\
\text { Units }\end{array}$ & $\begin{array}{r}\text { Single } \\
\text { Unit } \\
\text { Homes }\end{array}$ & $\begin{array}{r}\text { Multi- } \\
\text { Unit } \\
\text { Homes }\end{array}$ & $\begin{array}{l}\text { Mobile } \\
\text { Homes }\end{array}$ \\
\hline Adams & 26,700 & $80.6 \%$ & $14.3 \%$ & $5.1 \%$ \\
\hline Alexander & 3,084 & $66.8 \%$ & $16.5 \%$ & $16.7 \%$ \\
\hline Bond & 6,312 & $80.9 \%$ & $9.1 \%$ & $10.0 \%$ \\
\hline Boone & 17,864 & $82.2 \%$ & $11.5 \%$ & $6.3 \%$ \\
\hline Brown & 2,105 & $81.1 \%$ & $14.1 \%$ & $4.8 \%$ \\
\hline Bureau & 14,289 & $86.5 \%$ & $11.2 \%$ & $2.3 \%$ \\
\hline Calhoun & 2,071 & $85.4 \%$ & $7.1 \%$ & $7.5 \%$ \\
\hline Carroll & 6,739 & $84.4 \%$ & $11.5 \%$ & $4.1 \%$ \\
\hline Cass & 5,070 & $79.4 \%$ & $9.1 \%$ & $11.5 \%$ \\
\hline Champaign & 79,267 & $62.1 \%$ & $33.9 \%$ & $4.0 \%$ \\
\hline Christian & 14,196 & $83.8 \%$ & $10.2 \%$ & $6.0 \%$ \\
\hline Clark & 6,593 & $81.9 \%$ & $8.0 \%$ & $10.1 \%$ \\
\hline Clay & 5,591 & $73.8 \%$ & $8.7 \%$ & $17.6 \%$ \\
\hline Clinton & 14,058 & $83.9 \%$ & $7.3 \%$ & $8.8 \%$ \\
\hline Coles & 21,156 & $70.2 \%$ & $23.9 \%$ & $6.0 \%$ \\
\hline Cook & $1,933,670$ & $48.0 \%$ & $51.2 \%$ & $0.7 \%$ \\
\hline Crawford & 7,741 & $83.2 \%$ & $7.1 \%$ & $9.8 \%$ \\
\hline Cumberland & 4,136 & $83.5 \%$ & $4.1 \%$ & $12.4 \%$ \\
\hline De Witt & 6,770 & $88.2 \%$ & $8.3 \%$ & $3.5 \%$ \\
\hline DeKalb & 37,959 & $69.5 \%$ & $27.9 \%$ & $2.6 \%$ \\
\hline Douglas & 7,613 & $85.1 \%$ & $11.1 \%$ & $3.8 \%$ \\
\hline DuPage & 335,532 & $73.8 \%$ & $26.0 \%$ & $0.2 \%$ \\
\hline Edgar & 7,879 & $85.3 \%$ & $9.6 \%$ & $5.2 \%$ \\
\hline Edwards & 2,742 & $77.9 \%$ & $6.1 \%$ & $16.0 \%$ \\
\hline Effingham & 13,643 & $82.3 \%$ & $11.3 \%$ & $6.4 \%$ \\
\hline Fayette & 8,191 & $79.5 \%$ & $6.8 \%$ & $13.7 \%$ \\
\hline Ford & 5,632 & $88.1 \%$ & $8.1 \%$ & $3.8 \%$ \\
\hline Franklin & 16,082 & $79.1 \%$ & $7.9 \%$ & $13.0 \%$ \\
\hline Fulton & 14,665 & $84.5 \%$ & $11.2 \%$ & $4.4 \%$ \\
\hline Gallatin & 2,364 & $74.3 \%$ & $7.5 \%$ & $18.2 \%$ \\
\hline Greene & 5,816 & $84.2 \%$ & $8.5 \%$ & $7.3 \%$ \\
\hline Grundy & 17,987 & $82.3 \%$ & $12.7 \%$ & $5.0 \%$ \\
\hline Hamilton & 3,501 & $79.2 \%$ & $5.4 \%$ & $15.4 \%$ \\
\hline Hancock & 8,053 & $85.0 \%$ & $9.2 \%$ & $5.8 \%$ \\
\hline Hardin & 1,903 & $71.0 \%$ & $8.3 \%$ & $20.7 \%$ \\
\hline Henderson & 3,219 & $83.8 \%$ & $3.2 \%$ & $13.0 \%$ \\
\hline Henry & 20,510 & $87.1 \%$ & $10.1 \%$ & $2.8 \%$ \\
\hline Iroquois & 11,935 & $87.2 \%$ & $9.2 \%$ & $3.6 \%$ \\
\hline Jackson & 23,496 & $58.1 \%$ & $29.3 \%$ & $12.6 \%$ \\
\hline
\end{tabular}

\begin{tabular}{|l|rrrr|}
\hline County & $\begin{array}{r}\text { Total } \\
\text { Units }\end{array}$ & $\begin{array}{r}\text { Single } \\
\text { Unit } \\
\text { Homes }\end{array}$ & $\begin{array}{r}\text { Multi- } \\
\text { Unit } \\
\text { Homes }\end{array}$ & $\begin{array}{r}\text { Mobile } \\
\text { Homes }\end{array}$ \\
\hline Jasper & 3,955 & $80.6 \%$ & $5.4 \%$ & $13.9 \%$ \\
Jefferson & 15,178 & $69.8 \%$ & $12.0 \%$ & $18.2 \%$ \\
Jersey & 8,736 & $85.0 \%$ & $7.1 \%$ & $7.9 \%$ \\
Jo Daviess & 9,731 & $85.6 \%$ & $10.8 \%$ & $3.6 \%$ \\
Johnson & 4,279 & $71.4 \%$ & $7.4 \%$ & $21.1 \%$ \\
Kane & 170,069 & $80.4 \%$ & $18.9 \%$ & $0.6 \%$ \\
Kankakee & 41,068 & $77.1 \%$ & $17.1 \%$ & $5.8 \%$ \\
Kendall & 37,817 & $92.1 \%$ & $7.7 \%$ & $0.2 \%$ \\
Knox & 21,736 & $79.2 \%$ & $17.5 \%$ & $3.3 \%$ \\
Lake & 240,744 & $80.0 \%$ & $18.3 \%$ & $1.7 \%$ \\
LaSalle & 44,709 & $83.7 \%$ & $12.0 \%$ & $4.3 \%$ \\
Lawrence & 6,047 & $80.1 \%$ & $10.4 \%$ & $9.5 \%$ \\
Lee & 13,686 & $82.4 \%$ & $13.3 \%$ & $4.3 \%$ \\
Livingston & 14,374 & $81.6 \%$ & $14.0 \%$ & $4.4 \%$ \\
Logan & 10,940 & $79.7 \%$ & $16.3 \%$ & $4.0 \%$ \\
Macon & 45,074 & $81.5 \%$ & $15.7 \%$ & $2.8 \%$ \\
Macoupin & 19,379 & $83.2 \%$ & $8.7 \%$ & $8.2 \%$ \\
Madison & 106,933 & $81.5 \%$ & $15.5 \%$ & $3.0 \%$ \\
Marion & 15,958 & $70.6 \%$ & $10.0 \%$ & $19.4 \%$ \\
Marshall & 5,092 & $91.2 \%$ & $7.0 \%$ & $1.8 \%$ \\
Mason & 6,400 & $84.4 \%$ & $7.4 \%$ & $8.2 \%$ \\
Massac & 6,157 & $74.8 \%$ & $7.8 \%$ & $17.3 \%$ \\
McDonough & 12,798 & $69.0 \%$ & $24.8 \%$ & $6.1 \%$ \\
McHenry & 108,950 & $88.9 \%$ & $10.5 \%$ & $0.5 \%$ \\
McLean & 63,709 & $68.7 \%$ & $26.8 \%$ & $4.5 \%$ \\
Menard & 5,062 & $86.3 \%$ & $8.5 \%$ & $5.2 \%$ \\
Mercer & 6,768 & $88.8 \%$ & $7.5 \%$ & $3.7 \%$ \\
Mone & 12,457 & $87.8 \%$ & $9.8 \%$ & $2.4 \%$ \\
Monroe & 1,793 & $71.7 \%$ & $7.4 \%$ & $20.9 \%$ \\
Morgan & $13,919,919$ & $84.1 \%$ & $10.2 \%$ & $5.7 \%$ \\
Moultrie & 5,615 & $86.9 \%$ & $7.7 \%$ & $5.4 \%$ \\
Ogle & 20,728 & $83.0 \%$ & $13.1 \%$ & $3.9 \%$ \\
Peoria & 75,847 & $76.1 \%$ & $22.3 \%$ & $1.6 \%$ \\
\hline
\end{tabular}


Appendix N, Continued: Proportion of Housing Types by County

\begin{tabular}{|l|r|rrr|}
\hline County & $\begin{array}{r}\text { Total } \\
\text { Units }\end{array}$ & $\begin{array}{r}\text { Single } \\
\text { Unit } \\
\text { Homes }\end{array}$ & $\begin{array}{r}\text { Multi- } \\
\text { Unit } \\
\text { Homes }\end{array}$ & $\begin{array}{r}\text { Mobile } \\
\text { Homes }\end{array}$ \\
\hline Putnam & 2,453 & $85.6 \%$ & $9.8 \%$ & $4.6 \%$ \\
Randolph & 11,820 & $77.6 \%$ & $8.9 \%$ & $13.5 \%$ \\
Richland & 6,658 & $79.5 \%$ & $8.9 \%$ & $11.6 \%$ \\
Rock Island & 60,670 & $76.7 \%$ & $20.8 \%$ & $2.5 \%$ \\
Saline & 10,347 & $77.3 \%$ & $9.2 \%$ & $13.4 \%$ \\
Sangamon & 82,402 & $78.0 \%$ & $17.0 \%$ & $4.9 \%$ \\
Schuyler & 3,086 & $86.6 \%$ & $5.3 \%$ & $8.2 \%$ \\
Scott & 2,118 & $83.2 \%$ & $8.4 \%$ & $8.4 \%$ \\
Shelby & 8,995 & $86.1 \%$ & $5.7 \%$ & $8.3 \%$ \\
St. Clair & 102,936 & $75.0 \%$ & $19.3 \%$ & $5.7 \%$ \\
Stark & 2,438 & $89.3 \%$ & $6.5 \%$ & $4.2 \%$ \\
Stephenson & 19,633 & $78.2 \%$ & $17.7 \%$ & $4.1 \%$ \\
\hline Tazewell & 54,308 & $84.8 \%$ & $13.2 \%$ & $2.0 \%$ \\
Union & 6,858 & $74.8 \%$ & $8.9 \%$ & $16.3 \%$ \\
Vermilion & 31,863 & $81.0 \%$ & $13.3 \%$ & $5.7 \%$ \\
Wabash & 4,759 & $81.5 \%$ & $8.4 \%$ & $10.1 \%$ \\
Warren & 6,882 & $84.8 \%$ & $12.2 \%$ & $3.0 \%$ \\
Washington & 6,024 & $86.7 \%$ & $3.1 \%$ & $10.2 \%$ \\
Wayne & 7,126 & $70.6 \%$ & $6.8 \%$ & $22.6 \%$ \\
White & 6,257 & $80.2 \%$ & $7.8 \%$ & $12.1 \%$ \\
Whiteside & 23,390 & $83.9 \%$ & $13.1 \%$ & $3.1 \%$ \\
Will & 222,092 & $87.4 \%$ & $11.3 \%$ & $1.3 \%$ \\
Williamson & 26,813 & $73.7 \%$ & $15.8 \%$ & $10.5 \%$ \\
Winnebago & 113,119 & $74.7 \%$ & $23.4 \%$ & $1.9 \%$ \\
Woodford & 14,251 & $88.5 \%$ & $7.6 \%$ & $3.9 \%$ \\
\hline
\end{tabular}


Appendix 0: Cost-Burdened Homeowners Age 65 and Older

\begin{tabular}{|c|c|c|c|c|c|c|c|}
\hline \multirow[b]{2}{*}{ County } & \multicolumn{3}{|c|}{ Householders Age 65 and Older } & \multirow[b]{2}{*}{ County } & \multicolumn{3}{|c|}{ Householders Age 65 and Older } \\
\hline & $\begin{array}{r}\text { Total } \\
\text { Households }\end{array}$ & $\begin{array}{r}\text { Number Cost- } \\
\text { Burdened }\end{array}$ & $\begin{array}{r}\text { Percent Cost- } \\
\text { Burdened }\end{array}$ & & $\begin{array}{r}\text { Total } \\
\text { Households }\end{array}$ & $\begin{array}{l}\text { Number Cost- } \\
\text { Burdened }\end{array}$ & $\begin{array}{l}\text { Percent Cost- } \\
\text { Burdened }\end{array}$ \\
\hline Adams & 5,895 & 1,317 & $22.3 \%$ & Jasper & 975 & 216 & $22.2 \%$ \\
\hline Alexander & 672 & 168 & $25.0 \%$ & Jefferson & 3,284 & 617 & $18.8 \%$ \\
\hline Bond & 1,459 & 275 & $18.8 \%$ & Jersey & 1,855 & 366 & $19.7 \%$ \\
\hline Boone & 3,273 & 950 & $29.0 \%$ & Jo Daviess & 2,678 & 682 & $25.5 \%$ \\
\hline Brown & 493 & 91 & $18.5 \%$ & Johnson & 1,173 & 227 & $19.4 \%$ \\
\hline Bureau & 3,483 & 707 & $20.3 \%$ & Kane & 25,794 & 9,531 & $37.0 \%$ \\
\hline Calhoun & 544 & 123 & $22.6 \%$ & Kankakee & 7,672 & 1,964 & $25.6 \%$ \\
\hline Carroll & 1,766 & 333 & $18.9 \%$ & Kendall & 4,336 & 1,392 & $32.1 \%$ \\
\hline Cass & 1,120 & 199 & $17.8 \%$ & Knox & 4,917 & 991 & $20.2 \%$ \\
\hline Champaign & 10,659 & 1,955 & $18.3 \%$ & Lake & 37,242 & 14,334 & $38.5 \%$ \\
\hline Christian & 3,302 & 635 & $19.2 \%$ & LaSalle & 10,228 & 2,549 & $24.9 \%$ \\
\hline Clark & 1,635 & 244 & $14.9 \%$ & Lawrence & 1,425 & 270 & $18.9 \%$ \\
\hline Clay & 1,379 & 268 & $19.4 \%$ & Lee & 2,845 & 685 & $24.1 \%$ \\
\hline Clinton & 3,098 & 770 & $24.9 \%$ & Livingston & 3,177 & 633 & $19.9 \%$ \\
\hline Coles & 3,941 & 775 & $19.7 \%$ & Logan & 2,603 & 434 & $16.7 \%$ \\
\hline Cook & 293,963 & 110,469 & $37.6 \%$ & Macon & 9,776 & 1,893 & $19.4 \%$ \\
\hline Crawford & 1,985 & 383 & $19.3 \%$ & Macoupin & 4,285 & 938 & $21.9 \%$ \\
\hline Cumberland & 1,020 & 247 & $24.2 \%$ & Madison & 20,599 & 4,456 & $21.6 \%$ \\
\hline De Witt & 1,558 & 270 & $17.3 \%$ & Marion & 3,667 & 721 & $19.7 \%$ \\
\hline DeKalb & 5,128 & 1,617 & $31.5 \%$ & Marshall & 1,349 & 288 & $21.3 \%$ \\
\hline Douglas & 1,635 & 307 & $18.8 \%$ & Mason & 1,646 & 371 & $22.5 \%$ \\
\hline DuPage & 53,430 & 18,069 & $33.8 \%$ & Massac & 1,414 & 311 & $22.0 \%$ \\
\hline Edgar & 1,898 & 336 & $17.7 \%$ & McDonough & 2,468 & 393 & $15.9 \%$ \\
\hline Edwards & 726 & 111 & $15.3 \%$ & McHenry & 16,832 & 6,397 & $38.0 \%$ \\
\hline Effingham & 3,034 & 674 & $22.2 \%$ & McLean & 9,168 & 1,903 & $20.8 \%$ \\
\hline Fayette & 1,946 & 372 & $19.1 \%$ & Menard & 1,011 & 227 & $22.5 \%$ \\
\hline Ford & 1,360 & 217 & $16.0 \%$ & Mercer & 1,657 & 293 & $17.7 \%$ \\
\hline Franklin & 4,157 & 807 & $19.4 \%$ & Monroe & 2,428 & 604 & $24.9 \%$ \\
\hline Fulton & 3,634 & 624 & $17.2 \%$ & Montgomery & 2,804 & 497 & $17.7 \%$ \\
\hline Gallatin & 628 & 86 & $13.7 \%$ & Morgan & 2,912 & 440 & $15.1 \%$ \\
\hline Greene & 1,465 & 325 & $22.2 \%$ & Moultrie & 1,294 & 251 & $19.4 \%$ \\
\hline Grundy & 2,981 & 810 & $27.2 \%$ & Ogle & 4,411 & 1,267 & $28.7 \%$ \\
\hline Hamilton & 926 & 148 & $16.0 \%$ & Peoria & 13,791 & 2,816 & $20.4 \%$ \\
\hline Hancock & 2,140 & 462 & $21.6 \%$ & Perry & 1,892 & 356 & $18.8 \%$ \\
\hline Hardin & 501 & 93 & $18.6 \%$ & Piatt & 1,576 & 291 & $18.5 \%$ \\
\hline Henderson & 921 & 163 & $17.7 \%$ & Pike & 1,664 & 281 & $16.9 \%$ \\
\hline Henry & 4,712 & 920 & $19.5 \%$ & Pope & 523 & 89 & $17.0 \%$ \\
\hline Iroquois & 2,858 & 522 & $18.3 \%$ & Pulaski & 685 & 154 & $22.5 \%$ \\
\hline Jackson & 3,531 & 503 & $14.2 \%$ & Putnam & 567 & 97 & $17.1 \%$ \\
\hline
\end{tabular}

Data Source: 2008-2012 Five-Year American Community Survey 
Appendix 0, Continued: Cost Burdened Homeowners Age 65 and Older

\begin{tabular}{|l|rrr|}
\hline \multirow{2}{*}{ County } & Householders Age 65 and Older \\
\cline { 2 - 4 } & $\begin{array}{r}\text { Total } \\
\text { Households }\end{array}$ & $\begin{array}{r}\text { Number Cost- } \\
\text { Burdened }\end{array}$ & $\begin{array}{r}\text { Percent Cost- } \\
\text { Burdened }\end{array}$ \\
\hline Randolph & 2,899 & 535 & $18.5 \%$ \\
Richland & 1,631 & 318 & $19.5 \%$ \\
Rock Island & 12,622 & 2,771 & $22.0 \%$ \\
Saline & 2,446 & 496 & $20.3 \%$ \\
Sangamon & 14,589 & 2,782 & $19.1 \%$ \\
Schuyler & 751 & 87 & $11.6 \%$ \\
Scott & 465 & 67 & $14.4 \%$ \\
Shelby & 2,404 & 565 & $23.5 \%$ \\
St. Clair & 17,981 & 4,178 & $23.2 \%$ \\
Stark & 694 & 112 & $16.1 \%$ \\
Stephenson & 4,744 & 1,223 & $25.8 \%$ \\
Tazewell & 11,546 & 2,078 & $18.0 \%$ \\
Union & 1,679 & 285 & $17.0 \%$ \\
Vermilion & 7,250 & 1,298 & $17.9 \%$ \\
Wabash & 1,151 & 280 & $24.3 \%$ \\
Warren & 1,614 & 369 & $22.9 \%$ \\
Washington & 1,404 & 251 & $17.9 \%$ \\
Wayne & 1,882 & 449 & $23.9 \%$ \\
White & 1,692 & 208 & $12.3 \%$ \\
Whiteside & 5,680 & 935 & $16.5 \%$ \\
Will & 32,727 & 11,352 & $34.7 \%$ \\
Williamson & 5,632 & 931 & $16.5 \%$ \\
Winnebago & 19,994 & 5,360 & $26.8 \%$ \\
Woodford & 2,868 & 510 & $17.8 \%$ \\
\hline
\end{tabular}


Appendix P: Rent-Burdened Households Age 65 and Older

\begin{tabular}{|c|c|c|c|c|c|c|c|}
\hline \multirow[b]{2}{*}{ County } & \multicolumn{3}{|c|}{ Householders Age 65 and Older } & \multirow[b]{2}{*}{ County } & \multicolumn{3}{|c|}{ Householders Age 65 and Older } \\
\hline & $\begin{array}{r}\text { Total } \\
\text { Households }\end{array}$ & $\begin{array}{r}\text { Number Rent- } \\
\text { Burdened }\end{array}$ & $\begin{array}{l}\text { Percent Rent- } \\
\text { Burdened }\end{array}$ & & $\begin{array}{r}\text { Total } \\
\text { Households }\end{array}$ & $\begin{array}{r}\text { Number Rent- } \\
\text { Burdened }\end{array}$ & $\begin{array}{l}\text { Percent Rent- } \\
\text { Burdened }\end{array}$ \\
\hline Adams & 1,486 & 658 & $44.3 \%$ & Jasper & 101 & 50 & $49.5 \%$ \\
\hline Alexander & 154 & 42 & $27.3 \%$ & Jefferson & 780 & 303 & $38.8 \%$ \\
\hline Bond & 329 & 130 & $39.5 \%$ & Jersey & 405 & 195 & $48.1 \%$ \\
\hline Boone & 392 & 148 & $37.8 \%$ & Jo Daviess & 373 & 161 & $43.2 \%$ \\
\hline Brown & 63 & 29 & $46.0 \%$ & Johnson & 212 & 89 & $42.0 \%$ \\
\hline Bureau & 744 & 375 & $50.4 \%$ & Kane & 4,765 & 3,185 & $66.8 \%$ \\
\hline Calhoun & 79 & 20 & $25.3 \%$ & Kankakee & 1,832 & 1,025 & $55.9 \%$ \\
\hline Carroll & 328 & 126 & $38.4 \%$ & Kendall & 686 & 289 & $42.1 \%$ \\
\hline Cass & 181 & 68 & $37.6 \%$ & Knox & 1,661 & 932 & $56.1 \%$ \\
\hline Champaign & 2,572 & 1,377 & $53.5 \%$ & Lake & 7,863 & 4,677 & $59.5 \%$ \\
\hline Christian & 814 & 291 & $35.7 \%$ & LaSalle & 1,845 & 790 & $42.8 \%$ \\
\hline Clark & 324 & 109 & $33.6 \%$ & Lawrence & 339 & 178 & $52.5 \%$ \\
\hline Clay & 224 & 87 & $38.8 \%$ & Lee & 647 & 216 & $33.4 \%$ \\
\hline Clinton & 510 & 263 & $51.6 \%$ & Livingston & 607 & 229 & $37.7 \%$ \\
\hline Coles & 857 & 285 & $33.3 \%$ & Logan & 509 & 213 & $41.8 \%$ \\
\hline Cook & 103,081 & 62,701 & $60.8 \%$ & McDonough & 443 & 166 & $37.5 \%$ \\
\hline Crawford & 257 & 126 & $49.0 \%$ & McHenry & 2,147 & 1,232 & $57.4 \%$ \\
\hline Cumberland & 128 & 36 & $28.1 \%$ & McLean & 2,035 & 958 & $47.1 \%$ \\
\hline DeKalb & 1,376 & 743 & $54.0 \%$ & Macon & 1,882 & 981 & $52.1 \%$ \\
\hline De Witt & 260 & 103 & $39.6 \%$ & Macoupin & 858 & 344 & $40.1 \%$ \\
\hline Douglas & 299 & 146 & $48.8 \%$ & Madison & 4,477 & 2,445 & $54.6 \%$ \\
\hline DuPage & 10,900 & 6,441 & $59.1 \%$ & Marion & 844 & 460 & $54.5 \%$ \\
\hline Edgar & 333 & 96 & $28.8 \%$ & Marshall & 191 & 60 & $31.4 \%$ \\
\hline Edwards & 79 & 30 & $38.0 \%$ & Mason & 219 & 77 & $35.2 \%$ \\
\hline Effingham & 629 & 175 & $27.8 \%$ & Massac & 288 & 157 & $54.5 \%$ \\
\hline Fayette & 225 & 88 & $39.1 \%$ & Menard & 233 & 63 & $27.0 \%$ \\
\hline Ford & 312 & 116 & $37.2 \%$ & Mercer & 268 & 84 & $31.3 \%$ \\
\hline Franklin & 753 & 302 & $40.1 \%$ & Monroe & 458 & 235 & $51.3 \%$ \\
\hline Fulton & 489 & 208 & $42.5 \%$ & Montgomery & 623 & 270 & $43.3 \%$ \\
\hline Gallatin & 126 & 37 & $29.4 \%$ & Morgan & 794 & 321 & $40.4 \%$ \\
\hline Greene & 196 & 51 & $26.0 \%$ & Moultrie & 226 & 115 & $50.9 \%$ \\
\hline Grundy & 562 & 265 & $47.2 \%$ & Ogle & 785 & 286 & $36.4 \%$ \\
\hline Hamilton & 162 & 78 & $48.1 \%$ & Peoria & 3,257 & 1,672 & $51.3 \%$ \\
\hline Hancock & 309 & 77 & $24.9 \%$ & Perry & 411 & 104 & $25.3 \%$ \\
\hline Hardin & 113 & 32 & $28.3 \%$ & Piatt & 180 & 70 & $38.9 \%$ \\
\hline Henderson & 90 & 20 & $22.2 \%$ & Pike & 363 & 146 & $40.2 \%$ \\
\hline Henry & 941 & 458 & $48.7 \%$ & Pope & 83 & 19 & $22.9 \%$ \\
\hline Iroquois & 753 & 427 & $56.7 \%$ & Pulaski & 102 & 74 & $72.5 \%$ \\
\hline Jackson & 808 & 320 & $39.6 \%$ & Putnam & 60 & 24 & $40.0 \%$ \\
\hline
\end{tabular}

Data Source: 2008-2012 Five-Year American Community Survey 
Appendix P, Continued: Rent-Burdened Households Age 65 and Older

\begin{tabular}{|l|rrr|}
\hline \multirow{2}{*}{ County } & \multicolumn{3}{|c|}{ Householders Age 65 and Older } \\
\cline { 2 - 4 } & $\begin{array}{r}\text { Total } \\
\text { Households }\end{array}$ & $\begin{array}{r}\text { Number Rent- } \\
\text { Burdened }\end{array}$ & $\begin{array}{r}\text { Percent Rent- } \\
\text { Burdened }\end{array}$ \\
\hline Randolph & 544 & 221 & $40.6 \%$ \\
Richland & 360 & 131 & $36.4 \%$ \\
Rock Island & 3,537 & 1,749 & $49.4 \%$ \\
St. Clair & 4,458 & 2,479 & $55.6 \%$ \\
Saline & 520 & 268 & $51.5 \%$ \\
Sangamon & 3,390 & 1,932 & $57.0 \%$ \\
Schuyler & 126 & 45 & $35.7 \%$ \\
Scott & 117 & 23 & $19.7 \%$ \\
Shelby & 364 & 132 & $36.3 \%$ \\
Stark & 73 & 12 & $16.4 \%$ \\
Stephenson & 995 & 465 & $46.7 \%$ \\
Tazewell & 2,282 & 919 & $40.3 \%$ \\
Union & 360 & 120 & $33.3 \%$ \\
Vermilion & 1,750 & 826 & $47.2 \%$ \\
Wabash & 268 & 81 & $30.2 \%$ \\
Warren & 339 & 173 & $51.0 \%$ \\
Washington & 230 & 105 & $45.7 \%$ \\
Wayne & 284 & 104 & $36.6 \%$ \\
White & 235 & 100 & $42.6 \%$ \\
Whiteside & 1,027 & 455 & $44.3 \%$ \\
Will & 5,048 & 3,084 & $61.1 \%$ \\
Williamson & 1,371 & 645 & $47.0 \%$ \\
Winnebago & 5,737 & 3,070 & $53.5 \%$ \\
Woodford & 542 & 258 & $47.6 \%$ \\
\hline
\end{tabular}


Appendix Q: Means of Transportation to Work

\begin{tabular}{|c|c|c|c|c|c|c|}
\hline \multirow[b]{2}{*}{ County } & \multicolumn{6}{|c|}{ Means of Transportation } \\
\hline & $\begin{array}{l}\text { Drove } \\
\text { Alone }\end{array}$ & Carpooled & $\begin{array}{l}\text { Public } \\
\text { Transit }\end{array}$ & Walked & $\begin{array}{r}\text { Taxi, Bicycle, } \\
\text { Other }\end{array}$ & $\begin{array}{r}\text { Worked at } \\
\text { Home }\end{array}$ \\
\hline Adams & $82.6 \%$ & $9.7 \%$ & $0.5 \%$ & $3.0 \%$ & $1.2 \%$ & $2.9 \%$ \\
\hline Alexander & $83.2 \%$ & $9.8 \%$ & $2.5 \%$ & $1.7 \%$ & $2.2 \%$ & $0.6 \%$ \\
\hline Bond & $79.6 \%$ & $7.8 \%$ & $1.9 \%$ & $4.8 \%$ & $0.8 \%$ & $5.0 \%$ \\
\hline Boone & $83.5 \%$ & $9.5 \%$ & $0.2 \%$ & $1.3 \%$ & $1.7 \%$ & $3.8 \%$ \\
\hline Brown & $86.7 \%$ & $3.7 \%$ & $2.4 \%$ & $1.1 \%$ & $2.3 \%$ & $3.8 \%$ \\
\hline Bureau & $81.1 \%$ & $11.3 \%$ & $0.4 \%$ & $3.1 \%$ & $1.1 \%$ & $2.9 \%$ \\
\hline Calhoun & $74.6 \%$ & $15.7 \%$ & $0.0 \%$ & $1.3 \%$ & $2.0 \%$ & $6.4 \%$ \\
\hline Carroll & $81.0 \%$ & $9.1 \%$ & $0.4 \%$ & $2.9 \%$ & $0.8 \%$ & $5.8 \%$ \\
\hline Cass & $77.8 \%$ & $14.4 \%$ & $0.3 \%$ & $1.8 \%$ & $0.8 \%$ & $4.9 \%$ \\
\hline Champaign & $68.3 \%$ & $8.8 \%$ & $6.1 \%$ & $8.7 \%$ & $3.1 \%$ & $4.9 \%$ \\
\hline Christian & $82.1 \%$ & $10.7 \%$ & $0.9 \%$ & $1.7 \%$ & $0.8 \%$ & $3.8 \%$ \\
\hline Clark & $83.5 \%$ & $8.8 \%$ & $0.0 \%$ & $1.2 \%$ & $1.4 \%$ & $5.1 \%$ \\
\hline Clay & $83.2 \%$ & $8.4 \%$ & $0.2 \%$ & $3.4 \%$ & $1.6 \%$ & $3.2 \%$ \\
\hline Clinton & $82.6 \%$ & $11.0 \%$ & $0.6 \%$ & $2.0 \%$ & $0.9 \%$ & $2.8 \%$ \\
\hline Coles & $76.4 \%$ & $10.7 \%$ & $1.0 \%$ & $6.5 \%$ & $1.4 \%$ & $4.0 \%$ \\
\hline Cook & $62.6 \%$ & $9.4 \%$ & $17.7 \%$ & $4.3 \%$ & $2.0 \%$ & $4.0 \%$ \\
\hline Crawford & $84.1 \%$ & $9.4 \%$ & $0.5 \%$ & $2.0 \%$ & $1.5 \%$ & $2.5 \%$ \\
\hline Cumberland & $79.5 \%$ & $10.5 \%$ & $0.0 \%$ & $0.7 \%$ & $1.1 \%$ & $8.2 \%$ \\
\hline De Witt & $83.5 \%$ & $10.6 \%$ & $0.2 \%$ & $1.9 \%$ & $0.7 \%$ & $3.1 \%$ \\
\hline DeKalb & $78.0 \%$ & $9.8 \%$ & $2.2 \%$ & $4.5 \%$ & $1.5 \%$ & $4.1 \%$ \\
\hline Douglas & $73.4 \%$ & $12.6 \%$ & $0.0 \%$ & $3.6 \%$ & $4.8 \%$ & $5.6 \%$ \\
\hline DuPage & $78.1 \%$ & $7.7 \%$ & $6.4 \%$ & $1.8 \%$ & $1.2 \%$ & $4.7 \%$ \\
\hline Edgar & $79.1 \%$ & $10.5 \%$ & $0.2 \%$ & $3.7 \%$ & $1.1 \%$ & $5.4 \%$ \\
\hline Edwards & $82.8 \%$ & $8.6 \%$ & $0.3 \%$ & $3.4 \%$ & $1.8 \%$ & $3.2 \%$ \\
\hline Effingham & $82.0 \%$ & $9.9 \%$ & $0.2 \%$ & $1.5 \%$ & $1.7 \%$ & $4.7 \%$ \\
\hline Fayette & $80.0 \%$ & $9.3 \%$ & $0.4 \%$ & $2.4 \%$ & $2.3 \%$ & $5.6 \%$ \\
\hline Ford & $81.0 \%$ & $12.0 \%$ & $0.1 \%$ & $3.1 \%$ & $0.8 \%$ & $3.2 \%$ \\
\hline Franklin & $85.6 \%$ & $8.2 \%$ & $0.4 \%$ & $2.0 \%$ & $1.1 \%$ & $2.6 \%$ \\
\hline Fulton & $81.7 \%$ & $11.3 \%$ & $0.1 \%$ & $3.2 \%$ & $1.2 \%$ & $2.6 \%$ \\
\hline Gallatin & $83.7 \%$ & $8.4 \%$ & $0.8 \%$ & $1.2 \%$ & $1.3 \%$ & $4.5 \%$ \\
\hline Greene & $75.3 \%$ & $15.1 \%$ & $0.0 \%$ & $4.0 \%$ & $1.1 \%$ & $4.5 \%$ \\
\hline Grundy & $85.4 \%$ & $7.9 \%$ & $0.9 \%$ & $1.5 \%$ & $1.0 \%$ & $3.3 \%$ \\
\hline Hamilton & $78.4 \%$ & $13.7 \%$ & $0.2 \%$ & $0.9 \%$ & $0.0 \%$ & $6.8 \%$ \\
\hline Hancock & $80.5 \%$ & $9.4 \%$ & $0.1 \%$ & $2.6 \%$ & $0.7 \%$ & $6.8 \%$ \\
\hline Hardin & $83.8 \%$ & $7.5 \%$ & $0.7 \%$ & $2.2 \%$ & $1.1 \%$ & $4.6 \%$ \\
\hline Henderson & $78.6 \%$ & $10.8 \%$ & $0.5 \%$ & $3.0 \%$ & $0.5 \%$ & $6.7 \%$ \\
\hline Henry & $82.7 \%$ & $11.2 \%$ & $0.1 \%$ & $1.6 \%$ & $1.0 \%$ & $3.4 \%$ \\
\hline Iroquois & $79.3 \%$ & $9.4 \%$ & $0.3 \%$ & $3.6 \%$ & $1.4 \%$ & $6.1 \%$ \\
\hline Jackson & $78.4 \%$ & $8.2 \%$ & $0.6 \%$ & $7.6 \%$ & $2.5 \%$ & $2.7 \%$ \\
\hline
\end{tabular}


Appendix Q, Continued: Means of Transportation to Work

\begin{tabular}{|c|c|c|c|c|c|c|}
\hline \multirow[b]{2}{*}{ County } & \multicolumn{6}{|c|}{ Means of Transportation } \\
\hline & $\begin{array}{l}\text { Drove } \\
\text { Alone }\end{array}$ & Carpooled & $\begin{array}{l}\text { Public } \\
\text { Transit }\end{array}$ & Walked & $\begin{array}{r}\text { Taxi, Bicycle, } \\
\text { Other }\end{array}$ & $\begin{array}{r}\text { Worked at } \\
\text { Home }\end{array}$ \\
\hline Jasper & $79.8 \%$ & $8.4 \%$ & $0.0 \%$ & $2.7 \%$ & $0.8 \%$ & $8.3 \%$ \\
\hline Jefferson & $82.8 \%$ & $9.1 \%$ & $0.6 \%$ & $1.9 \%$ & $2.2 \%$ & $3.5 \%$ \\
\hline Jersey & $83.7 \%$ & $8.3 \%$ & $0.1 \%$ & $2.7 \%$ & $0.5 \%$ & $4.7 \%$ \\
\hline Jo Daviess & $78.3 \%$ & $9.3 \%$ & $0.6 \%$ & $4.4 \%$ & $0.9 \%$ & $6.5 \%$ \\
\hline Johnson & $86.1 \%$ & $7.8 \%$ & $0.3 \%$ & $1.8 \%$ & $0.8 \%$ & $3.2 \%$ \\
\hline Kane & $80.5 \%$ & $8.8 \%$ & $2.6 \%$ & $1.5 \%$ & $1.8 \%$ & $4.7 \%$ \\
\hline Kankakee & $81.1 \%$ & $9.3 \%$ & $2.0 \%$ & $2.8 \%$ & $1.3 \%$ & $3.6 \%$ \\
\hline Kendall & $84.1 \%$ & $7.0 \%$ & $2.7 \%$ & $0.5 \%$ & $1.0 \%$ & $4.6 \%$ \\
\hline Knox & $83.1 \%$ & $7.7 \%$ & $0.4 \%$ & $3.9 \%$ & $1.8 \%$ & $3.0 \%$ \\
\hline Lake & $76.2 \%$ & $9.1 \%$ & $4.2 \%$ & $2.8 \%$ & $1.4 \%$ & $6.4 \%$ \\
\hline LaSalle & $84.1 \%$ & $8.8 \%$ & $0.2 \%$ & $2.6 \%$ & $1.3 \%$ & $3.0 \%$ \\
\hline Lawrence & $79.0 \%$ & $14.8 \%$ & $0.5 \%$ & $1.7 \%$ & $1.3 \%$ & $2.6 \%$ \\
\hline Lee & $81.6 \%$ & $10.2 \%$ & $1.2 \%$ & $1.7 \%$ & $0.9 \%$ & $4.4 \%$ \\
\hline Livingston & $83.3 \%$ & $9.1 \%$ & $0.2 \%$ & $2.9 \%$ & $1.0 \%$ & $3.6 \%$ \\
\hline Logan & $83.3 \%$ & $9.2 \%$ & $0.6 \%$ & $3.3 \%$ & $1.5 \%$ & $2.0 \%$ \\
\hline Macon & $85.9 \%$ & $7.1 \%$ & $1.1 \%$ & $2.2 \%$ & $1.8 \%$ & $1.9 \%$ \\
\hline Macoupin & $83.2 \%$ & $9.7 \%$ & $0.3 \%$ & $3.0 \%$ & $0.8 \%$ & $3.0 \%$ \\
\hline Madison & $85.8 \%$ & $7.1 \%$ & $1.4 \%$ & $1.2 \%$ & $1.1 \%$ & $3.3 \%$ \\
\hline Marion & $81.5 \%$ & $10.0 \%$ & $0.5 \%$ & $2.0 \%$ & $1.9 \%$ & $4.1 \%$ \\
\hline Marshall & $79.6 \%$ & $12.1 \%$ & $0.1 \%$ & $2.9 \%$ & $1.4 \%$ & $4.0 \%$ \\
\hline Mason & $80.4 \%$ & $10.6 \%$ & $0.1 \%$ & $3.3 \%$ & $1.8 \%$ & $3.8 \%$ \\
\hline Massac & $86.2 \%$ & $7.5 \%$ & $0.7 \%$ & $1.9 \%$ & $1.6 \%$ & $2.1 \%$ \\
\hline McDonough & $76.3 \%$ & $8.6 \%$ & $1.1 \%$ & $7.9 \%$ & $2.3 \%$ & $3.7 \%$ \\
\hline McHenry & $82.3 \%$ & $7.5 \%$ & $2.8 \%$ & $1.2 \%$ & $1.0 \%$ & $5.1 \%$ \\
\hline McLean & $79.7 \%$ & $8.8 \%$ & $1.6 \%$ & $5.1 \%$ & $1.6 \%$ & $3.2 \%$ \\
\hline Menard & $77.7 \%$ & $15.3 \%$ & $0.0 \%$ & $1.4 \%$ & $0.7 \%$ & $4.9 \%$ \\
\hline Mercer & $79.7 \%$ & $11.4 \%$ & $0.0 \%$ & $1.9 \%$ & $1.4 \%$ & $5.5 \%$ \\
\hline Monroe & $83.8 \%$ & $10.7 \%$ & $0.8 \%$ & $1.4 \%$ & $0.2 \%$ & $3.1 \%$ \\
\hline Montgomery & $81.0 \%$ & $9.6 \%$ & $0.2 \%$ & $2.6 \%$ & $0.8 \%$ & $5.8 \%$ \\
\hline Morgan & $79.9 \%$ & $11.4 \%$ & $0.3 \%$ & $3.4 \%$ & $1.5 \%$ & $3.4 \%$ \\
\hline Moultrie & $78.4 \%$ & $8.1 \%$ & $0.0 \%$ & $2.5 \%$ & $6.0 \%$ & $4.9 \%$ \\
\hline Ogle & $82.2 \%$ & $9.9 \%$ & $0.5 \%$ & $2.8 \%$ & $1.0 \%$ & $3.6 \%$ \\
\hline Peoria & $83.1 \%$ & $8.3 \%$ & $2.0 \%$ & $2.3 \%$ & $1.5 \%$ & $2.7 \%$ \\
\hline Perry & $83.4 \%$ & $11.4 \%$ & $0.9 \%$ & $1.3 \%$ & $0.8 \%$ & $2.3 \%$ \\
\hline Piatt & $81.9 \%$ & $9.5 \%$ & $0.2 \%$ & $3.4 \%$ & $1.1 \%$ & $3.9 \%$ \\
\hline Pike & $75.7 \%$ & $12.5 \%$ & $0.7 \%$ & $3.5 \%$ & $2.2 \%$ & $5.4 \%$ \\
\hline Pope & $77.2 \%$ & $14.5 \%$ & $0.2 \%$ & $2.5 \%$ & $0.9 \%$ & $4.9 \%$ \\
\hline Pulaski & $84.6 \%$ & $8.5 \%$ & $1.6 \%$ & $2.3 \%$ & $0.0 \%$ & $3.0 \%$ \\
\hline Putnam & $80.7 \%$ & $13.6 \%$ & $0.0 \%$ & $1.1 \%$ & $0.5 \%$ & $4.2 \%$ \\
\hline
\end{tabular}


Appendix Q, Continued: Means of Transportation to Work

\begin{tabular}{|l|rrrrrr|}
\hline \multirow{2}{*}{ County } & \multicolumn{7}{|c|}{ Means of Transportation } \\
\cline { 2 - 8 } & $\begin{array}{r}\text { Drove } \\
\text { Alone }\end{array}$ & Carpooled & $\begin{array}{r}\text { Public } \\
\text { Transit }\end{array}$ & $\begin{array}{r}\text { Walked } \\
\text { Taxi, Bicycle, } \\
\text { Other }\end{array}$ & $\begin{array}{r}\text { Worked at } \\
\text { Home }\end{array}$ \\
\hline Randolph & $82.1 \%$ & $11.6 \%$ & $0.1 \%$ & $2.2 \%$ & $0.7 \%$ & $3.2 \%$ \\
Richland & $83.1 \%$ & $8.9 \%$ & $0.6 \%$ & $2.0 \%$ & $1.7 \%$ & $3.6 \%$ \\
Rock Island & $83.4 \%$ & $8.6 \%$ & $1.5 \%$ & $2.3 \%$ & $1.4 \%$ & $2.8 \%$ \\
Saline & $84.6 \%$ & $8.6 \%$ & $0.5 \%$ & $1.3 \%$ & $1.5 \%$ & $3.5 \%$ \\
Sangamon & $82.2 \%$ & $10.0 \%$ & $1.6 \%$ & $1.9 \%$ & $1.1 \%$ & $3.1 \%$ \\
Schuyler & $79.6 \%$ & $11.7 \%$ & $0.4 \%$ & $4.1 \%$ & $0.7 \%$ & $3.6 \%$ \\
Scott & $78.3 \%$ & $9.9 \%$ & $0.1 \%$ & $3.5 \%$ & $0.3 \%$ & $7.9 \%$ \\
Shelby & $82.4 \%$ & $8.3 \%$ & $0.1 \%$ & $1.7 \%$ & $0.7 \%$ & $6.8 \%$ \\
St. Clair & $81.6 \%$ & $8.5 \%$ & $3.8 \%$ & $1.8 \%$ & $1.3 \%$ & $2.9 \%$ \\
Stark & $76.4 \%$ & $11.3 \%$ & $0.3 \%$ & $2.7 \%$ & $0.9 \%$ & $8.3 \%$ \\
Stephenson & $80.0 \%$ & $10.4 \%$ & $0.8 \%$ & $2.7 \%$ & $1.3 \%$ & $4.7 \%$ \\
Tazewell & $85.4 \%$ & $9.0 \%$ & $0.5 \%$ & $1.7 \%$ & $0.7 \%$ & $2.8 \%$ \\
Union & $79.9 \%$ & $13.0 \%$ & $0.7 \%$ & $3.2 \%$ & $0.8 \%$ & $2.5 \%$ \\
Vermilion & $81.7 \%$ & $10.0 \%$ & $0.9 \%$ & $3.0 \%$ & $1.2 \%$ & $3.2 \%$ \\
Wabash & $81.8 \%$ & $10.5 \%$ & $0.5 \%$ & $1.0 \%$ & $2.9 \%$ & $3.4 \%$ \\
Warren & $76.2 \%$ & $10.7 \%$ & $0.4 \%$ & $5.6 \%$ & $1.9 \%$ & $5.2 \%$ \\
Washington & $83.5 \%$ & $7.7 \%$ & $0.2 \%$ & $2.9 \%$ & $0.8 \%$ & $4.9 \%$ \\
Wayne & $83.1 \%$ & $9.3 \%$ & $0.3 \%$ & $2.6 \%$ & $1.1 \%$ & $3.6 \%$ \\
White & $82.4 \%$ & $10.3 \%$ & $0.8 \%$ & $2.4 \%$ & $1.0 \%$ & $3.1 \%$ \\
Whiteside & $82.5 \%$ & $9.8 \%$ & $0.8 \%$ & $1.7 \%$ & $2.0 \%$ & $3.2 \%$ \\
Will & $82.2 \%$ & $7.5 \%$ & $4.1 \%$ & $0.9 \%$ & $1.2 \%$ & $4.0 \%$ \\
Williamson & $86.4 \%$ & $8.7 \%$ & $0.5 \%$ & $1.2 \%$ & $1.0 \%$ & $2.1 \%$ \\
Winnebago & $84.5 \%$ & $8.8 \%$ & $1.0 \%$ & $1.2 \%$ & $1.1 \%$ & $3.4 \%$ \\
Woodford & $83.3 \%$ & $9.9 \%$ & $0.1 \%$ & $1.9 \%$ & $1.4 \%$ & $3.5 \%$ \\
\hline
\end{tabular}


Appendix R: Households without a Vehicle

\begin{tabular}{|c|c|c|c|c|c|c|}
\hline \multirow{3}{*}{ County } & \multicolumn{3}{|c|}{ All Households } & \multicolumn{3}{|c|}{ Households Age 65+ } \\
\hline & \multirow{2}{*}{$\begin{array}{r}\text { Total } \\
\text { Households }\end{array}$} & \multicolumn{2}{|c|}{ No Vehicle } & \multirow{2}{*}{$\begin{array}{r}\text { Total } \\
\text { Households }\end{array}$} & \multicolumn{2}{|c|}{ No Vehicle } \\
\hline & & Number & Percent & & Number & Percent \\
\hline Adams & 26,700 & 1,717 & $6.4 \%$ & 7,381 & 671 & $9.1 \%$ \\
\hline Alexander & 3,084 & 454 & $14.7 \%$ & 826 & 105 & $12.7 \%$ \\
\hline Bond & 6,312 & 369 & $5.8 \%$ & 1,788 & 231 & $12.9 \%$ \\
\hline Boone & 17,864 & 715 & $4.0 \%$ & 3,665 & 228 & $6.2 \%$ \\
\hline Brown & 2,105 & 115 & $5.5 \%$ & 556 & 53 & $9.5 \%$ \\
\hline Bureau & 14,289 & 875 & $6.1 \%$ & 4,227 & 464 & $11.0 \%$ \\
\hline Calhoun & 2,071 & 61 & $2.9 \%$ & 623 & 19 & $3.0 \%$ \\
\hline Carroll & 6,739 & 333 & $4.9 \%$ & 2,094 & 172 & $8.2 \%$ \\
\hline Cass & 5,070 & 231 & $4.6 \%$ & 1,301 & 112 & $8.6 \%$ \\
\hline Champaign & 79,267 & 8,834 & $11.1 \%$ & 13,231 & 1,474 & $11.1 \%$ \\
\hline Christian & 14,196 & 851 & $6.0 \%$ & 4,116 & 355 & $8.6 \%$ \\
\hline Clark & 6,593 & 341 & $5.2 \%$ & 1,959 & 114 & $5.8 \%$ \\
\hline Clay & 5,591 & 227 & $4.1 \%$ & 1,603 & 131 & $8.2 \%$ \\
\hline Clinton & 14,058 & 629 & $4.5 \%$ & 3,608 & 369 & $10.2 \%$ \\
\hline Coles & 21,156 & 1,629 & $7.7 \%$ & 4,798 & 526 & $11.0 \%$ \\
\hline Cook & 1,933,670 & 341,453 & $17.7 \%$ & 397,044 & 97,870 & $24.6 \%$ \\
\hline Crawford & 7,741 & 372 & $4.8 \%$ & 2,242 & 182 & $8.1 \%$ \\
\hline Cumberland & 4,136 & 171 & $4.1 \%$ & 1,148 & 84 & $7.3 \%$ \\
\hline De Witt & 6,770 & 233 & $3.4 \%$ & 1,818 & 79 & $4.3 \%$ \\
\hline DeKalb & 37,959 & 2,519 & $6.6 \%$ & 6,504 & 846 & $13.0 \%$ \\
\hline Douglas & 7,613 & 803 & $10.5 \%$ & 1,934 & 225 & $11.6 \%$ \\
\hline DuPage & 335,532 & 13,498 & $4.0 \%$ & 64,330 & 7,538 & $11.7 \%$ \\
\hline Edgar & 7,879 & 566 & $7.2 \%$ & 2,231 & 232 & $10.4 \%$ \\
\hline Edwards & 2,742 & 190 & $6.9 \%$ & 805 & 22 & $2.7 \%$ \\
\hline Effingham & 13,643 & 728 & $5.3 \%$ & 3,663 & 326 & $8.9 \%$ \\
\hline Fayette & 8,191 & 343 & $4.2 \%$ & 2,171 & 168 & $7.7 \%$ \\
\hline Ford & 5,632 & 338 & $6.0 \%$ & 1,672 & 226 & $13.5 \%$ \\
\hline Franklin & 16,082 & 1,183 & $7.4 \%$ & 4,910 & 432 & $8.8 \%$ \\
\hline Fulton & 14,665 & 799 & $5.4 \%$ & 4,123 & 378 & $9.2 \%$ \\
\hline Gallatin & 2,364 & 134 & $5.7 \%$ & 754 & 54 & $7.2 \%$ \\
\hline Greene & 5,816 & 283 & $4.9 \%$ & 1,661 & 118 & $7.1 \%$ \\
\hline Grundy & 17,987 & 828 & $4.6 \%$ & 3,543 & 311 & $8.8 \%$ \\
\hline Hamilton & 3,501 & 101 & $2.9 \%$ & 1,088 & 62 & $5.7 \%$ \\
\hline Hancock & 8,053 & 309 & $3.8 \%$ & 2,449 & 169 & $6.9 \%$ \\
\hline Hardin & 1,903 & 138 & $7.3 \%$ & 614 & 56 & $9.1 \%$ \\
\hline Henderson & 3,219 & 158 & $4.9 \%$ & 1,011 & 88 & $8.7 \%$ \\
\hline Henry & 20,510 & 1,160 & $5.7 \%$ & 5,653 & 556 & $9.8 \%$ \\
\hline Iroquois & 11,935 & 596 & $5.0 \%$ & 3,611 & 361 & $10.0 \%$ \\
\hline
\end{tabular}


Appendix R, Continued: Households without a Vehicle

\begin{tabular}{|c|c|c|c|c|c|c|}
\hline \multirow{3}{*}{ County } & \multicolumn{3}{|c|}{ All Households } & \multicolumn{3}{|c|}{ Households Age 65+ } \\
\hline & \multirow{2}{*}{$\begin{array}{r}\text { Total } \\
\text { Households }\end{array}$} & \multicolumn{2}{|c|}{ No Vehicle } & \multirow{2}{*}{$\begin{array}{r}\text { Total } \\
\text { Households }\end{array}$} & \multicolumn{2}{|c|}{ No Vehicle } \\
\hline & & Number & Percent & & Number & Percent \\
\hline Jackson & 23,496 & 2,520 & $10.7 \%$ & 4,339 & 577 & $13.3 \%$ \\
\hline Jasper & 3,955 & 182 & $4.6 \%$ & 1,076 & 82 & $7.6 \%$ \\
\hline Jefferson & 15,178 & 1,335 & $8.8 \%$ & 4,064 & 519 & $12.8 \%$ \\
\hline Jersey & 8,736 & 300 & $3.4 \%$ & 2,260 & 194 & $8.6 \%$ \\
\hline Jo Daviess & 9,731 & 567 & $5.8 \%$ & 3,051 & 206 & $6.8 \%$ \\
\hline Johnson & 4,279 & 190 & $4.4 \%$ & 1,385 & 140 & $10.1 \%$ \\
\hline Kane & 170,069 & 8,364 & $4.9 \%$ & 30,559 & 3,743 & $12.2 \%$ \\
\hline Kankakee & 41,068 & 2,844 & $6.9 \%$ & 9,504 & 1,198 & $12.6 \%$ \\
\hline Kendall & 37,817 & 816 & $2.2 \%$ & 5,022 & 360 & $7.2 \%$ \\
\hline Knox & 21,736 & 2,067 & $9.5 \%$ & 6,578 & 865 & $13.1 \%$ \\
\hline Lake & 240,744 & 11,849 & $4.9 \%$ & 45,105 & 5,307 & $11.8 \%$ \\
\hline LaSalle & 44,709 & 2,503 & $5.6 \%$ & 12,073 & 1,276 & $10.6 \%$ \\
\hline Lawrence & 6,047 & 219 & $3.6 \%$ & 1,764 & 147 & $8.3 \%$ \\
\hline Lee & 13,686 & 859 & $6.3 \%$ & 3,492 & 309 & $8.8 \%$ \\
\hline Livingston & 14,374 & 887 & $6.2 \%$ & 3,784 & 357 & $9.4 \%$ \\
\hline Logan & 10,940 & 696 & $6.4 \%$ & 3,112 & 297 & $9.5 \%$ \\
\hline Macon & 45,074 & 4,042 & $9.0 \%$ & 11,658 & 1,251 & $10.7 \%$ \\
\hline Macoupin & 19,379 & 992 & $5.1 \%$ & 5,143 & 426 & $8.3 \%$ \\
\hline Madison & 106,933 & 6,325 & $5.9 \%$ & 25,076 & 2,601 & $10.4 \%$ \\
\hline Marion & 15,958 & 1,224 & $7.7 \%$ & 4,511 & 458 & $10.2 \%$ \\
\hline Marshall & 5,092 & 182 & $3.6 \%$ & 1,540 & 70 & $4.5 \%$ \\
\hline Mason & 6,400 & 396 & $6.2 \%$ & 1,865 & 136 & $7.3 \%$ \\
\hline Massac & 6,157 & 430 & $7.0 \%$ & 1,702 & 290 & $17.0 \%$ \\
\hline McDonough & 12,798 & 920 & $7.2 \%$ & 2,911 & 315 & $10.8 \%$ \\
\hline McHenry & 108,950 & 3,199 & $2.9 \%$ & 18,979 & 1,637 & $8.6 \%$ \\
\hline McLean & 63,709 & 3,971 & $6.2 \%$ & 11,203 & 1,141 & $10.2 \%$ \\
\hline Menard & 5,062 & 264 & $5.2 \%$ & 1,244 & 123 & $9.9 \%$ \\
\hline Mercer & 6,768 & 299 & $4.4 \%$ & 1,925 & 171 & $8.9 \%$ \\
\hline Monroe & 12,457 & 440 & $3.5 \%$ & 2,886 & 286 & $9.9 \%$ \\
\hline Montgomery & 11,547 & 635 & $5.5 \%$ & 3,427 & 348 & $10.2 \%$ \\
\hline Morgan & 13,919 & 807 & $5.8 \%$ & 3,706 & 400 & $10.8 \%$ \\
\hline Moultrie & 5,615 & 530 & $9.4 \%$ & 1,520 & 158 & $10.4 \%$ \\
\hline Ogle & 20,728 & 1,002 & $4.8 \%$ & 5,196 & 415 & $8.0 \%$ \\
\hline Peoria & 75,847 & 7,027 & $9.3 \%$ & 17,048 & 2,055 & $12.1 \%$ \\
\hline Perry & 8,136 & 384 & $4.7 \%$ & 2,303 & 183 & $7.9 \%$ \\
\hline Piatt & 6,428 & 261 & $4.1 \%$ & 1,756 & 128 & $7.3 \%$ \\
\hline Pike & 6,610 & 282 & $4.3 \%$ & 2,027 & 151 & $7.4 \%$ \\
\hline Pope & 1,793 & 144 & $8.0 \%$ & 606 & 65 & $10.7 \%$ \\
\hline
\end{tabular}


Appendix R, Continued: Households without a Vehicle

\begin{tabular}{|c|c|c|c|c|c|c|}
\hline \multirow{3}{*}{ County } & \multicolumn{3}{|c|}{ All Households } & \multicolumn{3}{|c|}{ Households Age 65+ } \\
\hline & \multirow{2}{*}{$\begin{array}{r}\text { Total } \\
\text { Households }\end{array}$} & \multicolumn{2}{|c|}{ No Vehicle } & \multirow{2}{*}{$\begin{array}{r}\text { Total } \\
\text { Households }\end{array}$} & \multicolumn{2}{|c|}{ No Vehicle } \\
\hline & & Number & Percent & & Number & Percent \\
\hline Pulaski & 2,414 & 279 & $11.6 \%$ & 787 & 144 & $18.3 \%$ \\
\hline Putnam & 2,453 & 72 & $2.9 \%$ & 627 & 35 & $5.6 \%$ \\
\hline Randolph & 11,820 & 622 & $5.3 \%$ & 3,443 & 343 & $10.0 \%$ \\
\hline Richland & 6,658 & 429 & $6.4 \%$ & 1,991 & 266 & $13.4 \%$ \\
\hline Rock Island & 60,670 & 5,592 & $9.2 \%$ & 16,159 & 2,365 & $14.6 \%$ \\
\hline Saline & 10,347 & 870 & $8.4 \%$ & 2,966 & 327 & $11.0 \%$ \\
\hline Sangamon & 82,402 & 5,797 & $7.0 \%$ & 17,979 & 2,188 & $12.2 \%$ \\
\hline Schuyler & 3,086 & 167 & $5.4 \%$ & 877 & 66 & $7.5 \%$ \\
\hline Scott & 2,118 & 96 & $4.5 \%$ & 582 & 64 & $11.0 \%$ \\
\hline Shelby & 8,995 & 520 & $5.8 \%$ & 2,768 & 295 & $10.7 \%$ \\
\hline St. Clair & 102,936 & 8,737 & $8.5 \%$ & 22,439 & 3,142 & $14.0 \%$ \\
\hline Stark & 2,438 & 76 & $3.1 \%$ & 767 & 23 & $3.0 \%$ \\
\hline Stephenson & 19,633 & 1,747 & $8.9 \%$ & 5,739 & 605 & $10.5 \%$ \\
\hline Tazewell & 54,308 & 2,736 & $5.0 \%$ & 13,828 & 1,288 & $9.3 \%$ \\
\hline Union & 6,858 & 466 & $6.8 \%$ & 2,039 & 195 & $9.6 \%$ \\
\hline Vermilion & 31,863 & 3,263 & $10.2 \%$ & 9,000 & 1,091 & $12.1 \%$ \\
\hline Wabash & 4,759 & 273 & $5.7 \%$ & 1,419 & 168 & $11.8 \%$ \\
\hline Warren & 6,882 & 409 & $5.9 \%$ & 1,953 & 187 & $9.6 \%$ \\
\hline Washington & 6,024 & 219 & $3.6 \%$ & 1,634 & 149 & $9.1 \%$ \\
\hline Wayne & 7,126 & 403 & $5.7 \%$ & 2,166 & 201 & $9.3 \%$ \\
\hline White & 6,257 & 409 & $6.5 \%$ & 1,927 & 126 & $6.5 \%$ \\
\hline Whiteside & 23,390 & 1,504 & $6.4 \%$ & 6,707 & 635 & $9.5 \%$ \\
\hline Will & 222,092 & 9,069 & $4.1 \%$ & 37,775 & 4,515 & $12.0 \%$ \\
\hline Williamson & 26,813 & 1,942 & $7.2 \%$ & 7,003 & 827 & $11.8 \%$ \\
\hline Winnebago & 113,119 & 9,091 & $8.0 \%$ & 25,731 & 3,278 & $12.7 \%$ \\
\hline Woodford & 14,251 & 497 & $3.5 \%$ & 3,410 & 182 & $5.3 \%$ \\
\hline
\end{tabular}


Appendix S: HSTP Regions and AAA Areas
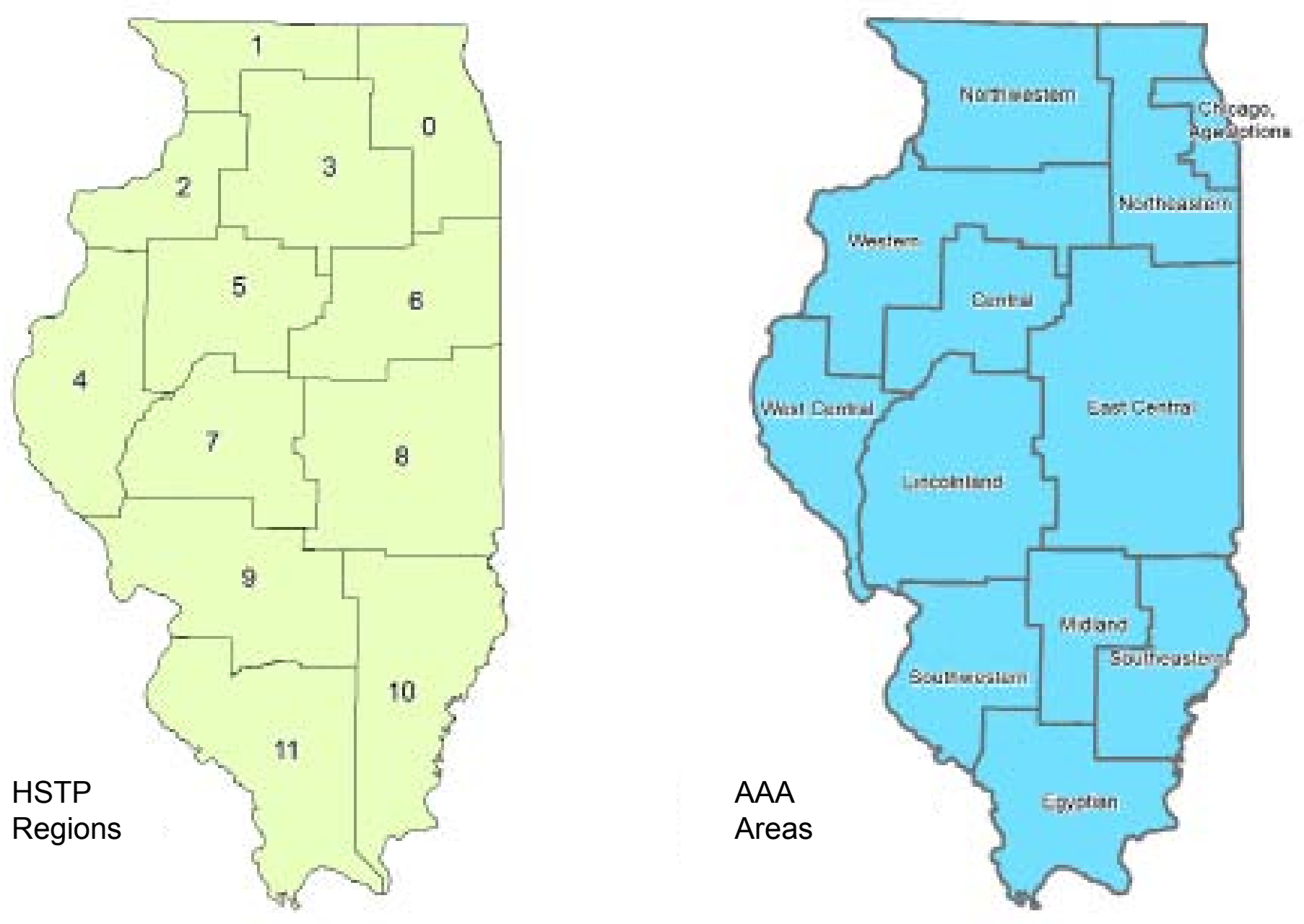

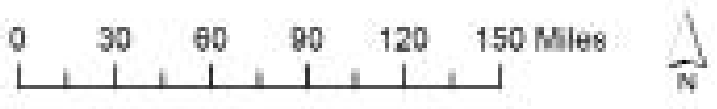


Appendix T: Overlaid HSTP Regions and AAA Areas

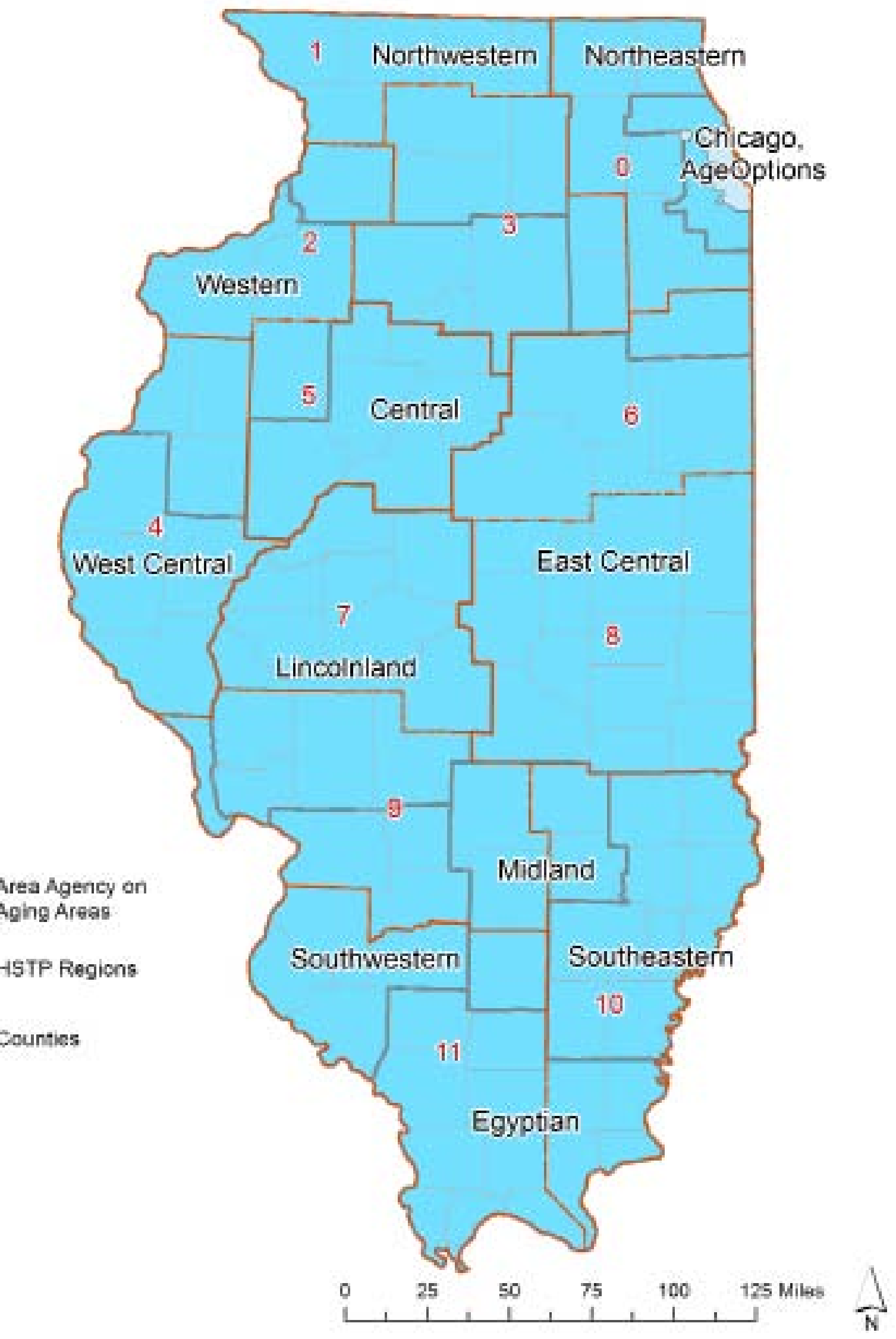


Appendix U: Counties and Selected Cities in Illinois
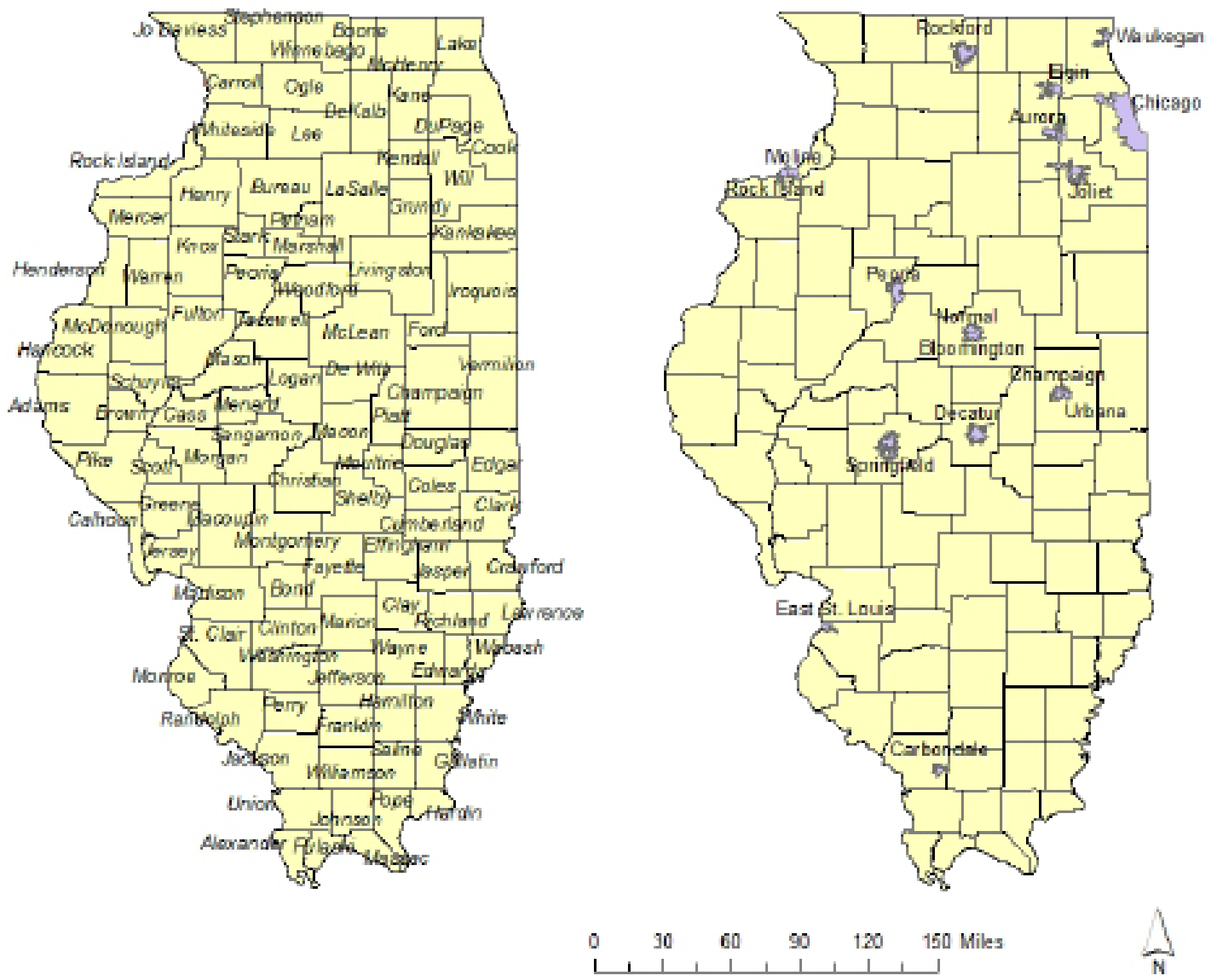
Appendix V: Institutional Review Board Exemption

\author{
UNIVERSITV OF ILLINOIS \\ AT CHICAGO
}

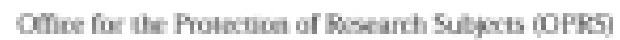

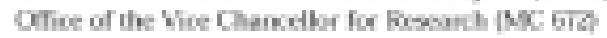

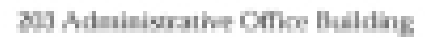

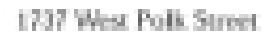

Cheme Ilimispilam

\title{
Extmption Grantud
}

July 8,2014

Yitingih Zclalem, JD, LLM MS

Nallatic P. Voothes Center

400 S. Pooria siree, Suile 2100, MC 345

Chiengo, II 60607

Phome $(312) 966-667 /$ Far $(312) 996-5766$

RE: Rosarch Protocol \# 2014-0541

"Transportation Needs of an Aging Population in Illinois"

Sponsors:

PAFH:

Grunt/Contruct No:

GrantiContract Title:
UIC Uiban Transportation Cenier

Not avalable

Not available

Transportation Needs Assessment

Dear Yittayih Zelalem:

Your Clain of Exempion was reviewed on July 8, 2014 and it was deternind dhat your reseanch mets the criteria for exemption. You may now begin your resench.

Fomption Period:

Performance Site:

Subject Population:

Number of Subjects:
Iuly 8, 2014 - July \$, 2017

UIC

Adult (18+ yours) subjous only

25

The specific exemption category under $45 \mathrm{CFR} 46.101(\mathrm{~b})$ is:

(2) Research involving the we of educational itests (cognitive, dizgnostic, aptitude, schievenent). survy prosedurs, inteview prosturs or abacrution of publis behavion, imles: (i) information obsainod is recorded in such a manner that human subjects can be identifiod, directy or through identifiers linked to the subjects and (ii) any disclosure of the human subjects' responses outside the rsearch ould reasmably place the sabjocts at risk of criminal or civil liability of be damaging to the subjects linancial sanding employability, ar repulaton.

Please nate the Review History of this submission:

\begin{tabular}{|c|c|c|c|c|}
\hline Raceipt Daits & Suhmision Type & Review Preses & Revics Dats & Revism hetinn \\
\hline 06432014 & Initial Favicw & Excmpt & $0672 / 2014$ & Madifications: Reyuinud \\
\hline $062 \pi 2014$ & Respanse to Madifications & Extmpt & 07082014 & Apponed \\
\hline
\end{tabular}




\section{Appendix V, Continued: Institutional Review Board Exemption}

$2014-0541$

Pege 2 of 3

July 8,2014

You are reminded that investigators whose research involving human subjects is determined to be exempt from the federal regulations for the prowetion of humm subjests still have responsibilitiss for the ethical condust of the research under state law and ULC policy. Please be aware of the following ULC policies and reponsibilities for investigators:

1. Amendments You are feponsuble for feporting any amendments to your feseanch protocol that may affect the determinatign of the exemption and myy result in your restarch no longer being cligible for the ecenption that bas becn granted.

2 Reourd Kepping You are responsible for maintaining a copy all research related records in a

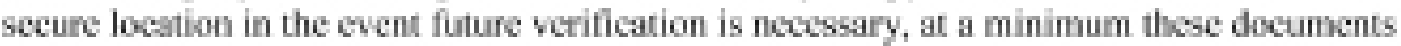
include: the research protucol, the claim of exemption application, all questionnaires, survey instruments, interview qustions andor datn collection instuments associated with

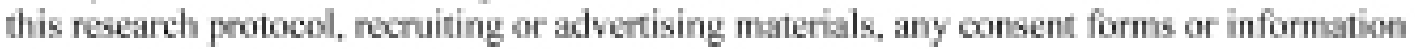
sheets given to subjects, or any other pertinent documents.

3. Final Report When you have complewd work on your rosearch probool, you should subat a final report to the Office for Protection of Research Subjects (OPRS).

4. Infomadion for Human Sublects UIC Policy requirs invenigalors to provide infontiation about the reseach protocol to subjects and to obtain their permision prior to their participating in the rescarch. The information about the reseanch protoed should be presented ta subjects in writing or orally from a written script. When appropriate, the following information must be provids to all research subjects participuting in exempt studies:

2. The researchers affiliation; ULC, JBVMMC or other institutions,

b. The purpose of the resarch,

c. The cotent of the subjot"s involvement and an cxplanation of the procodures to be followed,

d. Whether the information being oollectod will be used for any purposes other than the proposd nestarth.

e A description of the procedures to protect the privacy of subjects and the confidentiality of the resanch information and dait;

f. Description of any ressonable foresenable risks,

2. Description of anticipared benefit,

h. A sabment that participation is woluniay and subjects can refose warticipate of cun stop at any time,

i. A satement that the resenraher is available to answer any questions that the subject may have and wheh includes the nante and phone number of the invorigator(s).

j. A statement that the UIC IRBMPRS or JBVMAC Patient Advocite Office is available if there are questions about subject"s rights which inchudes the appopriate phone numbers.

Plese be sure to:

$\rightarrow$ Use your resseh protosol number (2014-0541) on any doeuments or correppowenes with the IRB someming your reserch protool. 
Appendix V, Continued: Institutional Review Board Exemption

2014-0541

Page 3 of 3

July 8,2014

We wish you the best as you conduct your research. If you have any questions or need further help, please contact the OPRS office at (312) 996-1711 or me at (312) 355-2908. Please send any correspondence about this protocol to OPRS at $203 \mathrm{AOB}, \mathrm{M} / \mathrm{C} 672$.

Sincerely,

Charles W. Hoehne, B.S., C.I.P.

Assistant Director

Office for the Protection of Research Subjects

cc: Patricia A. Wright, Nathalie P. Voorhees Center, M/C 345 
Appendix W: Stakeholder Conversations

1. Bert Weber \& Betsy Creamer - Illinois Department of Aging - February 20, 2014

2. Lise Dirks - University of Illinois at Chicago - March 31, 2014

3. Sylvia Mahle - South Central/Midland Area Agency on Aging (Planning \& Service Area 9) - April 8, 2014

4. John Edmondson - Illinois Department of Transportation - April 11, 2014

5. Kiyeon Koch - Southwestern Area on Aging (Planning \& Service Area 8) - April 14, 2014

6. Bill Jung - RIDES Mass Transit District - April 15, 2014

7. Barbara Eskildsen - Western Illinois Area Agency on Aging (Planning \& Service Area 3) - April 16, 2014

8. Renee Razo - Central Illinois Area Agency on Aging (Planning \& Service Area 4) - April 16, 2014

9. Eileen Sierra-Brown - Champaign County Regional Planning Commission/HSTP Coordinator Region 8 - April 17, 2014

10. Lindsay Whitson - Bi-State Regional Commission/HSTP Coordinator Region 2 - April 17, 2014

11. Joe Voccia \& Jay Chivarella - Regional Transportation Authority/HSTP Coordinators “Region 0" - April 18,2014

12. Ed Heflin - Rural Transit Assistance Center, Western Illinois University - April 18/22/30, 2014

13. Jennifer Sicks - McLean County Regional Planning Commission/HSTP Coordinator Region 6 - April 18,2014

14. Jill Goforth - Tri-County Regional Planning Commission/HSTP Coordinator Region 5 - April 21, 2014

15. Kim Blechschmidt - Age Options/ Suburban Cook County Area Agency on Aging (Planning \& Service Area 13) - April 24, 2014

16. Jacob Matsen - North Central Illinois Council of Governments/HSTP Coordinator Regions 1 \& 3 April 25, 2014

17. Amy St. Peter - Maricopa County (AZ) Association of Governments - April 28, 2014

18. Tom Groeninger - Pace (metropolitan Chicago region) - April 30, 2014

19. Royal White \& Tim Lobdell - Western Illinois Regional Council/HSTP Coordinators (current \& past)

Regions 4 \& 7 - April 30, 2014

20. Roland Mross -- Community Transportation Association of America - May 5, 2014

21. Meredith Morgenroth - On the Go/Jewish Family Services of San Diego - May 5, 2014

22. Lorraine Snowden \& Mike Bolton - Pace - May 9, 2014

23. Carol Reagan - Palatine Township Older adult Citizens Council - May 22, 2014 


\section{Appendix X: References}

American Public Transportation Association (undated). The Business Case for Mobility Management. Washington, D.C.

Department of Commerce and Economic Opportunity County Population Projections, 2005. Retrieved March 26, 2014 from Data.Illinois.Gov data portal: https://data.illinois.gov/Economics/DCEO-County-PopulationProjections/h3bx-hbbh

Foley, D.J., Heimovitz, H.K., Guralnik, J.M., \& Brock, D.B. (2002). Driving Life Expectancy of Persons Aged 70 Years and Older in the United States. American Journal of Public Health, Vol 92, No. 8.

Illinois Association of Area Agencies on Aging (2011). The Maturing of Illinois: Getting Communities on Track for an Aging Population. Springfield, IL.

Illinois Department of Transportation (2007). Illinois State Transportation Plan Sub-Report: Human Services Transportation. Springfield, IL.

Illinois Department of Transportation (2012). Transforming Transportation for Tomorrow: Illinois State Transportation Plan 2012 . Springfield, IL.

Illinois Department of Transportation. (2012). Illinois State Transportation Plan. www.illinoistransportationplan.org

Illinois Department of Human Services (2008). Evaluation of Transportation Services and Systems Final Technical Report \#2: Opportunities for Coordination: Evaluation of Existing Services and Best Practice Models. Springfield, IL.

Illinois Council on Developmental Disabilities (2006). Potential and Feasibility for Coordination of Transportation Services in Illinois. Springfield, IL.

Insurance Institute for Highway Saftey. (2014, February 20). Fit for the road: older driver's crash rates continue to drop. Status Report, Vol 1, No. 1. www.iihs.org

Harrell, R., Lynott, J. \& Guzman S. (2014). What is Livable? Community Preferences of Older Americans. AARP Public Policy Institute. Washington, D.C.

Lynott, J., Fox-Gage W. \& Guzman S. (2013). Weaving it Together: A Tapestry of Transportation Funding for Older Adults. AARP Public Policy Institute. Washington, D.C.

Morken, L. \& Warner, M. (2012). Planning for the Aging Population: Rural Responses to the Challenge. prepared for the National Association of Area Agencies on Aging.

National Resource Center for Human Service Transportation Coordination. (2009). Report to the Secretary of Transportation. Washington, D.C.

National Resource Center for Human Service Transportation Coordination. (2011). Transportation for America's Veterans and Their Families. Washington, D.C. 


\section{Appendix X, Continued: References}

National Center on Senior Transportation. (2007). Seniors Benefit from Transportation Coordination Partnerships - A Toolkit: Promising Practices from the Aging Network. Washington, D.C.

National Center on Senior Transportation. (2011). NCST Today: Partnerships Between Public Transportation Agencies and Aging Service Providers. Washington, D.C.

Ortman, Jennifer (February 7, 2013). U.S. Population Projections: 2012 to 2060. PowerPoint presentation downloaded May 7, 2014 from George Washington University site: www.gwu.edu/ forcpgm/Ortman.pdf

Report to the Governor and General Assembly of Illinois. (2006). Public Act 93-0185: Interagency Coordinating Committee on Transportation. Springfield, IL.

Rosenbloom, S. (2009). Meeting Transportation Needs in an Aging-Friendly Community. Generations - Journal of the American Society on Aging, Vol 33, No. 2.

Rural Transit Assistance Center, Illinois Institute for Rural Affairs, Western Illiniois University. (2010). ICCT Clearinghouse Transportation Coordination Primer (Fourth Edition). Macomb, IL.

Transportation Research Board. (2003). Transit Cooperative Research Program Synthesis 91: Economic Benefits of CoordinatingHuman Service Transportation and Transit Services. Washington, D.C.

Transportation Research Board. (2004). Transit Cooperative Research Program Synthesis 101: Toolkit for Rural Community Coordinated Transportation Services. Washington, D.C.

Transportation Research Board. (2004). Transit Cooperative Research Program Synthesis 105: Strategies to Increase Coordination of Transportation Services for the Transportation Disadvantaged. Washington, D.C.

Transportation Research Board. (2011). Transit Cooperative Research Program Synthesis 94: Innovative Rural Transit Services. Washington, D.C.

Transportation Research Board. (2011). Research Results DIiest 99: Improving Mobility for Veterans. Washington, D.C.

Transportation for America. (2011). Aging in Place, Stuck without Options: Fixing the Mobility Crisis Threatening the Baby Boom Generation. Washington, D.C.

TRANSPRO Information Management System. Urban Transportation Center, University of Illinois at Chicago. Retreived June 19, 2014 from http://www.utc.uic.edu/tranpro/.

U.S. Census Bureau. (2012). American Community Survey and Puerto Rican Community Survey 2012 Subject Definitions. Washington, D.C.

U.S. Census Bureau. 2012 National Population Projections. Retrieved May 7, 2014 from www.census.gov/ population/projections/data/national/2012/summarytables.html 


\section{Appendix X, Continued: References}

U.S. Census Bureau. 2008 National Population Projections. Retrieved May 7, 2014 from www.census.gov/ population/projections/data/national/2008/summarytables.html

U.S. Census Bureau, 2010 Decennial Census, Summary File 1, Tables DP1, P12, P25, P26, PCO1, and PCO5. Retrieved March 26, 2014 from factfinder2.census.gov/faces/nav/jsf/pages/index.xhtml

U.S. Census Bureau. 2008-2012 5 Year American Community Survey. Retrieved May 1, 2014 from www.census. gov.

U.S. Census Bureau, 2008-2012 5 Year American Community Survey, Table B23004. Retrieved March 26, 2014 from factfinder2.census.gov/faces/nav/jsf/pages/index.xhtml

U.S. Department of Transportation \& U.S. Department of Housing and Urban Development. (2011). Federal Barriers to Local Housing and Transportation Coordination. Washington, D.C.

U.S. Government Accountability Office. (2008). Metropolitan Planning Organizations: Options Exist to Enhance Transportation Planning Capacity and Federal Oversight. Washington, D.C.

U.S. Government Accountability Office. (2012). Transportation-Disadvantaged Populations: Federal Coordination Efforts Could Be Further Strengthened. Washington, D.C.

U.S. Government Accountability Office. (2013). Transportation-Disadvantaged Populations: Coordination Efforts are Underway, but Challenges Continue. Washington, D.C.

U.S. Government Accountability Office. (2014). Public Transit: Challenges Funding, Investing in Systems, and Coordinating Services. Washington, D.C. 
PLANNING TRANSPORTATION TO MEET THE NEEDS OF AN AGING ILLINOIS: AN ASSESSMENT

THIS PAGE INTENTIONALLY LEFT BLANK 
Nathalie P. Voorhees Center for Neighborhood and Community Improvement College of Urban Planning and Public Affairs University of Illinois at Chicago

\section{P. $312-996-6336$}

F. 312-996-5766

400 South Peoria St., Suite 2100

Chicago, IL 60607

www.uic.edu/cuppa/voorheesctr/ 